UNIVERSIDADE DE SÃO PAULO

PROGRAMA DE PÓS-GRADUAÇÃO EM INTEGRAÇÃO DA AMÉRICA LATINA PROLAM/USP

LIANA MARIA MILANEZ PEREIRA

Instabilidades recorrentes da TV Pública

Estudos de caso: Brasil e Colômbia

São Paulo 
LIANA MARIA MILANEZ PEREIRA

Instabilidades recorrentes da TV Pública

Estudos de caso: Brasil e Colômbia

\author{
Versão corrigida
}

Tese apresentada ao Programa de Pós-Graduação em Integração da América Latina da Universidade de São Paulo (PROLAM-USP) como parte dos requisitos para obtenção do título de doutora em Ciências sob orientação da Profa. Dra. Cremilda Celeste de Araújo Medina.

Linha de Pesquisa: Comunicação e Cultura

São Paulo 
Autorizo a reprodução e divulgação total ou parcial deste trabalho, por qualquer meio convencional ou eletrônico, para fins de estudo e pesquisa, desde que citada a fonte.

Catalogação na Publicação

Serviço de Bỉblioteca e Documentação

Faculdade de Fllosofia, Letras e Ciências Humanas da Universidade de São Paulo

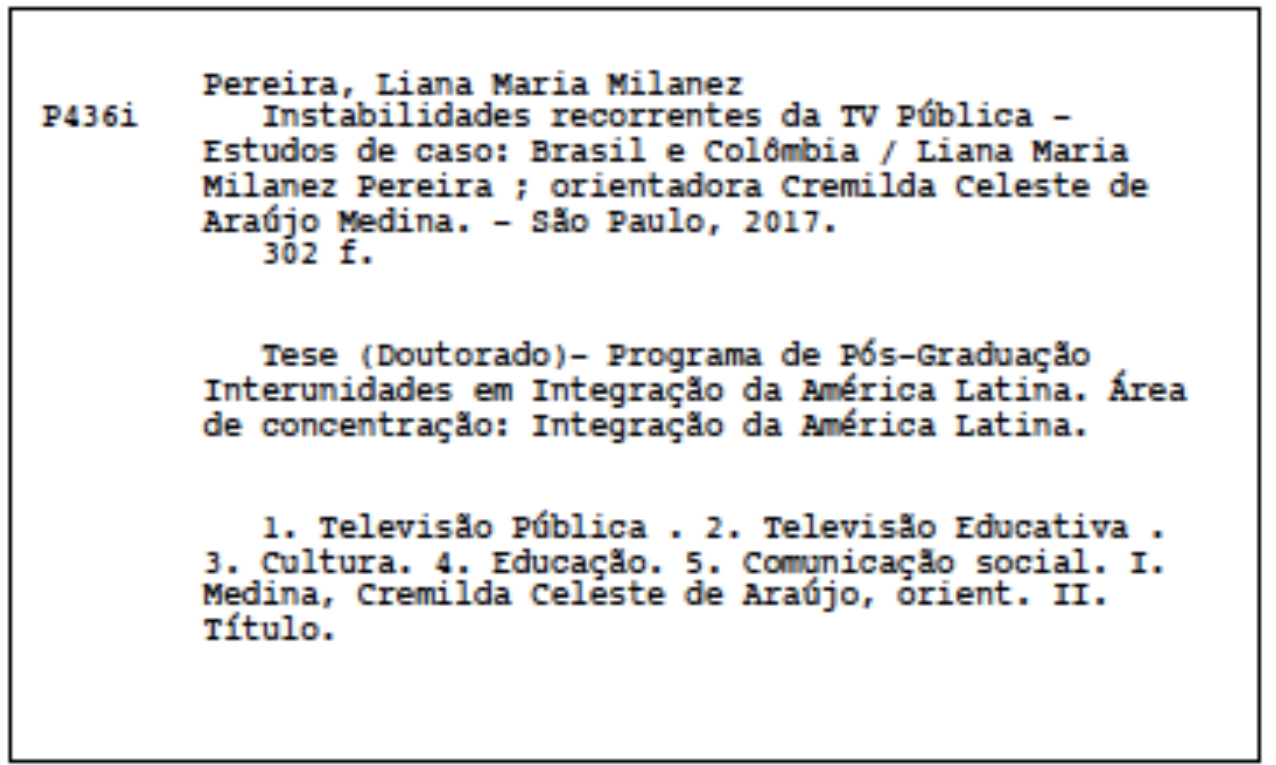


Nome: PEREIRA, Liana M. Milanez

Título: Instabilidades recorrentes da TV Pública - Estudos de caso: Brasil e Colômbia

Tese apresentada ao Programa de Pós-Graduação em Integração da América Latina da Universidade de São Paulo para obtenção do título de Doutora em Ciências.

Aprovada em:

Banca Examinadora

Prof(a). Dr(a) Instituição:

Julgamento: Assinatura:

Prof(a). Dr(a) Instituição:

Julgamento: Assinatura:

Prof(a). Dr(a) Instituição:

Julgamento: Assinatura:

Prof(a). Dr(a) Instituição:

Julgamento: Assinatura:

Prof(a). Dr(a) Instituição:

Julgamento: Assinatura: 


\section{AGRADECIMENTOS}

À minha orientadora, Profa. Dra. Cremilda Medina, mestra que me iluminou com seus saberes e me ensinou a enfrentar os revezes da vida com a mesma disposição com que nos brinda com a "sua epistemologia" abrindo nossos caminhos para o diálogo social e, mais que isso, solidário.

Aos professores Renato Seixas e Eugênio Bucci, pelas importantes contribuições durante o exame de qualificação.

Aos professores com quem partilhei momentos de convívio, tanto cursando disciplinas como em atividades de trabalho, como Claudia Fazzolari, Elizabeth Cancelli, Gisela Zaremberg, Julio Pires, Maria Cristina Cacciamali, Mara Rovida e Pedro Ortiz.

À minha querida e amada família, meu companheiro Newton, sempre solidário e paciente com minhas turbulências de humor nos momentos de tensão e estresse decorrentes desta pesquisa e dos fatos tristes da vida; minha filha Carolina, paciente em me ensinar a ter calma para enfrentar as situações difíceis sem afligir a mim e aos que me rodeiam; Felipe, meu filho e inspirador no amadurecimento intelectual e na disposição para vencer os obstáculos e desafios - meu exemplo de persistência e coragem para domar os tempos difíceis; minha nora Maíra, modelo de luta, competência e talento brindados pela perspicácia para destrinchar os meandros da pesquisa, assim como brava guerreira contra as injustiças sociais e as discriminações que ainda amordaçam os distintos gêneros; meu genro Henrique, com sua amabilidade e sensatez, me transmitiu paz nos momentos de maiores dificuldades aplacando minhas dores.

Aos meus pais Fernando e Jacy (in memorian) pelo amor que disseminaram entre tantos filhos recebidos e escolhidos, pela lição de respeito, honestidade e solidariedade.

À minha saudosa mãe Odarice (in memorian), que tomei emprestado do Newton, quando a nossa nos deixou.

Às Profas. Dras. Lisbeth Rebollo, Vivian Urquidi, Marilene Proença, Maria Cristina Cacciamali e professor Marcio Bobik, pelo convívio e aprendizado na Comissão de PóGraduação (CPG) do PROLAM e a todo o corpo docente por eles aqui representados.

A Beth (Elizabeth) Carmona pelo convite para viver uma das experiências mais marcantes de minha vida, referendadas nesta tese e nos livros citados no primeiro capítulo. 
A Rosa Crescente, parceira de momentos da vida e dessa caminhada pela televisão pública, pelo apoio, companheirismo e aprendizado.

Às minhas irmãs Ana e Lia que deram origem ao meu nome, sempre disponíveis para o amor. Ao professor Omar Rincón que iluminou o caminho para este trabalho, com sua obra e os ensinamentos partilhados em nosso encontro na Colômbia.

Aos profissionais colombianos que solidariamente partilharam suas histórias e conhecimentos sobre televisão pública em nossos encontros em Bogotá: Adelaida Trujillo, Alexandra Falla, Claudia Patricia González, Claudia Rodríguez Valencia, Diana Díaz Soto, Germán Franco, Jaime Tenório, Marcela Benavides, Patricia Castaño, Tatiana Duplat e Sandra Téllez.

Aos amigos de sempre Giovana e Sergio Lirio, companheiros no afeto e solidariedade, que nos presentearam com duas maravilhas.

Aos amados afilhados paulistanos Julia e Bernardo, um presente de carinho que recebemos nesta terra que adotamos.

Aos afilhados gaúchos Caio, Dariela e Luciano e a todos os sobrinhos por eles representados. Aos meus irmãos João Carlos e Yegor (in memorian) e ao Luiz Fernando.

Aos adoráveis Maruska Kubik e Vinicius Mano, que me acolheram em Bataguassu para que a redação dessa tese não fosse interrompida, minha eterna gratidão.

À amiga Ana Vicentini, que me ajudou a sair de um momento de sufoco também me acolhendo e abrindo caminhos para meu equilíbrio.

À Dra. Sara Hassan, que me fez acreditar que era possível.

Às queridas amigas Valdete Cecato, Bia Toledo e Mariluza Costa, sempre disponíveis para os encontros, socorros e afetos.

À querida “irmandade” do grupo de pesquisa Epistemologia do Diálogo Social, Angela Farah, Gean Gonçalves (que me auxiliou na revisão desta tese), Marcelle Souza, Marcos Zibordi, Jaqueline Lemos, Carlos Sandano, Paulo Quadros, Isabel Amphilo, Regina Cunha, Giovana Botti (que também contribuiu com a revisão), Talles Rodrigues, e tantos outros amigos que frequentaram nossos encontros e a disciplina de nossa mestra Cremilda Medina.

Aos insubstituíveis Sueli Anastacio, Marcelo Brissac, Liara Avellar, Luiza Pupo (in memorian), Marina Barreto, André Silva e Roberto Montero parceiros de um projeto e solidários no apoio longe da família, representando todos os amigos da Rádio MEC e Acerp. À comadre e amiga Profa. Dra. Maria Helena Weber pelo estímulo e contribuição de sempre. Ao Prolam e à USP pela infraestrutura que me permitiu acesso a conhecimentos e partilhas sobre a América Latina. 
Aos amigos William Almeida e Rodrigo Bronze, secretário e técnico acadêmico do PROLAM, pelo suporte e ajuda nesses três anos e meio.

A todos os amigos que, mesmo distantes, continuam próximos e solidários, minha gratidão! 


\section{RESUMO}

Esta tese procura fazer um breve percurso na história de duas emissoras públicas latinoamericanas - a TV Brasil e a Señal Colombia -, com ênfase nas mudanças de gestão, decorrentes de suas vinculações aos governos. Pesquisamos suas trajetórias para demonstrar as descontinuidades nos processos de gestão e buscamos entender, em uma revisão bibliográfica, a noção de televisão pública, um conceito em crise e em disputa. Por se definirem como emissoras educativas e culturais, investigamos o que representa esse binômio e como estas se apresentam institucionalmente, usando esses significados como indispensáveis na formação da cidadania. Optamos por traçar paralelos, apontando diferenças e similaridades entre as duas emissoras, ao invés de um estudo comparativo, respeitando as diferenças socioculturais e históricas de cada país.

Palavras chaves: TV pública, televisão educativa, televisão educativa e cultural, TV Brasil, Señal Colômbia. 


\begin{abstract}
This thesis aims to review the history of two Latin American public broadcasters - TV Brasil and Señal Colombia - focusing on management changes related to their attachment to governments. We searched its trajectories to demonstrate the discontinuities in themanagement processes, and we tried to understand, in a bibliographical review, the notion of public television, a concept in crisis and indispute. By defining themselves as educational and cultural broadcasters, we investigate what this binomial represents and how they appear institutionally, using those indispensable meanings for the formation of citizenship. We chose to draw parallels, pointing out differences and similarities between the two broadcasters, rather than a comparative study, respecting the socio-cultural and historical differences of each country.
\end{abstract}

Keywords: Public TV, educational television, cultural television, TV Brasil, Señal Colombia. 


\section{RÉSUMEN}

Esta tesis busca hacer un breve recorrido en la historia de dos emisoras públicas latinoamericanas - la TV Brasil y Señal Colombia-, con énfasis en los cambios de gestión, derivados de sus vinculaciones a los gobiernos. Hemos investigado sus trayectorias para presentar las discontinuidades en los procesos de gestión y buscamos comprender, por una revisión bibliográfica, la noción de televisión pública, un concepto en crisis y en disputa. Por definirense como emisoras educativas y culturales, investigamos lo que representa ese binomio y cómo éstas se presentan institucionalmente utilizando esos significados como indispensables en la formación de la ciudadanía. Optamos por trazar paralelos, señalando diferencias y semejanzas entre las dos emisoras, en lugar de un estudio comparativo, respetando las diferencias socioculturales e históricas de cada país.

Palabras claves: TV pública, televisión educativa, televisión educativa y cultural, TV Brasil, Señal Colombia. 


\section{LISTA DE ABREVIATURAS E SIGLAS}

ABEPEC Associação Brasileira de Emissoras Públicas Educativas e Culturais

ABPI-TV Associação Brasileira de Produtoras Independentes de Televisão

ABTU Associação Brasileira de Televisões Universitárias

ACERP Associação de Comunicação Educativa Roquette-Pinto

ANTV Autoridad Nacional de Televisión

CNTV Comisión Nacional de Televisión

Colcultura Instituto Colombiano de Cultura

DIP Departamento de Imprensa e Propaganda

DNP Departamento Nacional de Propaganda

DocTV Programa de Fomento à Produção e Teledifusão do Documentário

EBC Empresa Brasil de Comunicação

FCPRTV Fundação Cultural Piratini Rádio e Televisão

FCBTVE Fundação Centro Brasileiro de TV Educativa

FNDC Fórum Nacional pela Democratização da Comunicação

FONTV Fondo para el Desarollo de la Televisión

INPUT International Public Television Screening Conferences

Inravisión Instituto Nacional de Radio y Televisión

Intervozes Coletivo Brasil de Comunicação Social

MEC Ministério de Educação

Midiativa Centro Brasileiro de Mídia para Crianças e Adolescentes

MinC Ministério da Cultura

MiniCom Ministério das Comunicações (Colômbia)

MinCultura Ministério de Cultura (Colômbia)

MinTIC Ministério de Tecnologías de la Información y las Comunicaciones (Colômbia)

PROCEM Proyecto Nacional de Educación y Cultura a través de los Medios Masivos de Comunicación

Radiobrás Empresa Brasileira de Comunicação

RPTV Rede Pública de Televisão

RTVC Radio Televisión Nacional de Colombia

Secom Secretaria Especial de Comunicação / Secretaria de Estado de

Comunicação do Governo

Sinted Sistema Nacional de TV Educativa 
Sinred Sistema Nacional de Radiodifusão Educativa

STF Supremo Tribunal Federal

TVE Televisão Educativa

UNICEF Fundo das Nações Unidas para a Infância 


\section{SUMÁRIO}

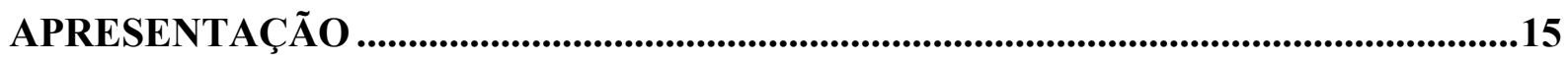

1. Memória e presente de duas TVs públicas na América Latina......................................20

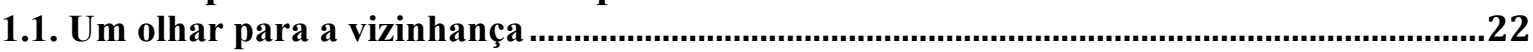

1.2. Preliminares: acertos e desacertos na criação de uma empresa de comunicação pública 25

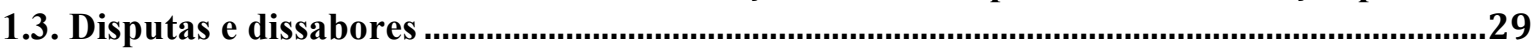

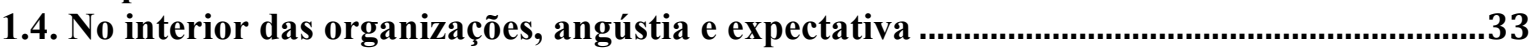

2. Um conceito em crise: Governamental, Estatal ou Pública? ........................................45

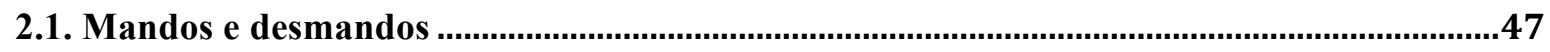

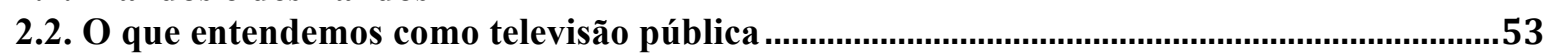

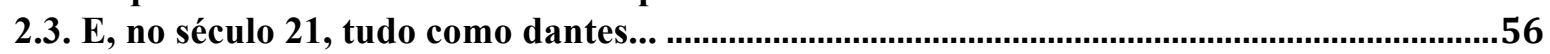

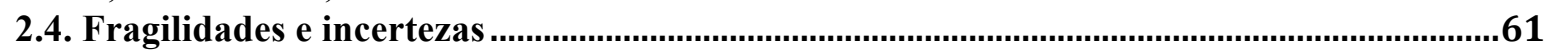

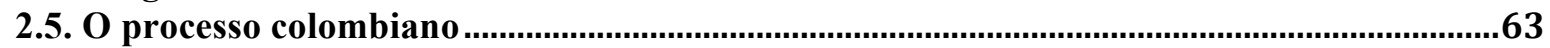

3. Televisão pública: riscos e recuos, o denominador comum .........................................67

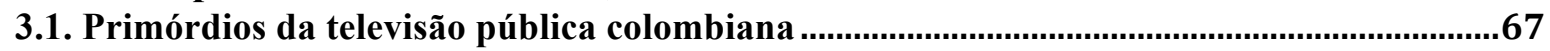

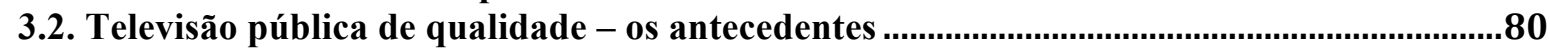

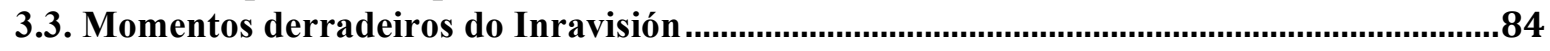

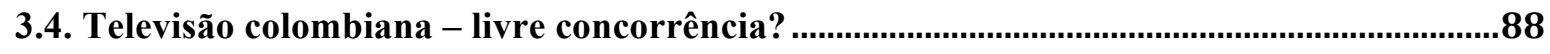

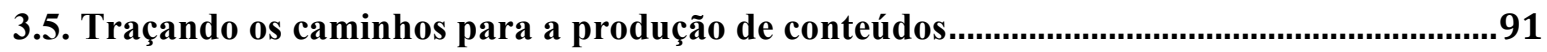

3.6. As trocas de gestores na Señal e a dança de cadeiras do andar superior ...................94

3.7. Estrutura e operação da RTVC segundo seus protagonistas.............................................101

3.8. A recuperacão da memória da rádio e televisão colombianas..............................................102

3.9. Independência - o clamor e a defesa de protagonistas e colaboradores..............................104

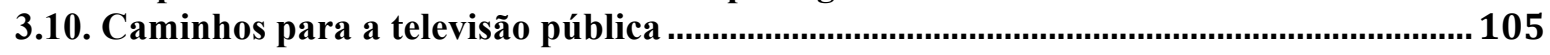

4. TV pública: a eterna desconstrução......................................................................................107

4.1. TVE Brasil, ontem. TV Brasil, hoje - Os antecedentes ......................................................... 107

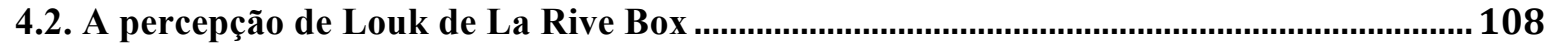

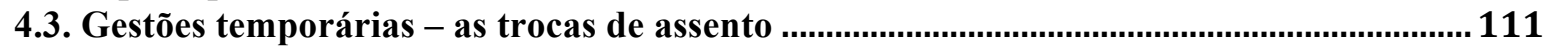

4.4. Entre parênteses: protagonismo e experiência de observação …........................................ 115

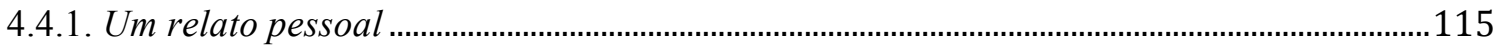

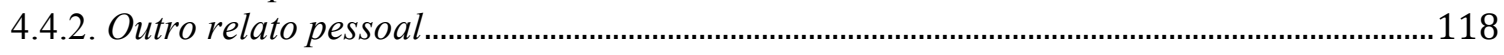

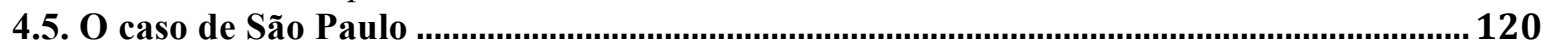

4.6. BBC - nosso modelo também sofre revezes...................................................................... 122

5. Produção de sentidos na TV Pública: Educação? Cultura? Entretenimento?...........127

5.1. Missões e pretensões - perspectiva institucional da educação e da cultura na Señal

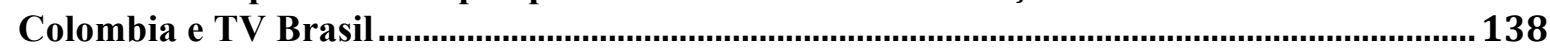

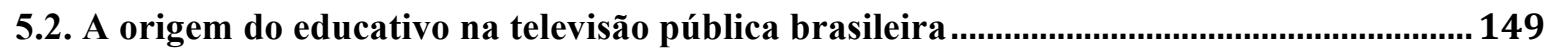

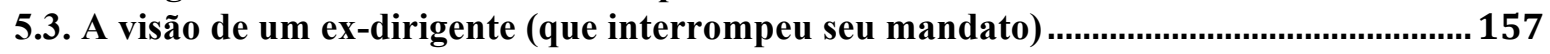

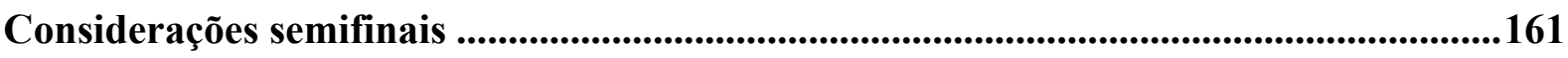

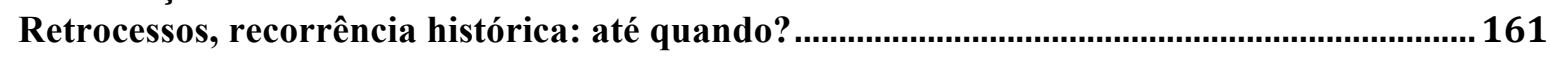

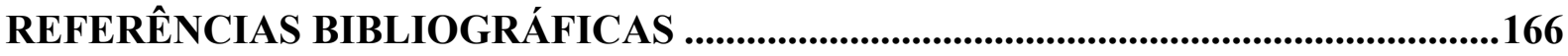

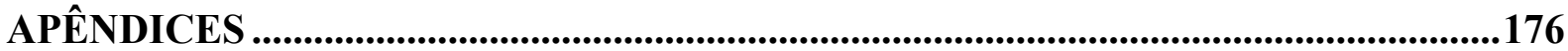

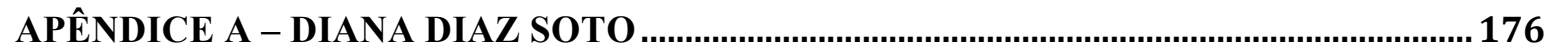

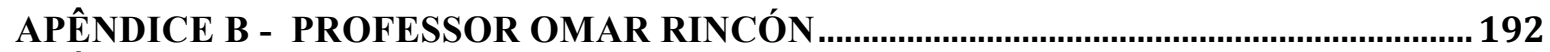

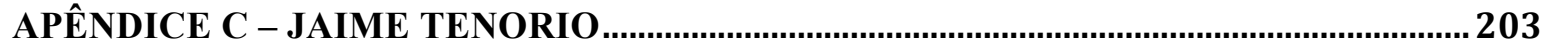


APÊNDICE D - MARCELA BENAVIDES

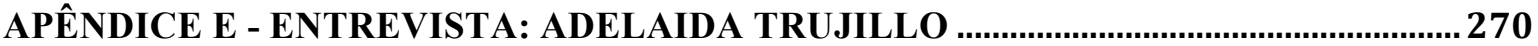

APÊNDICE F - PATRICIA CASTAÑO

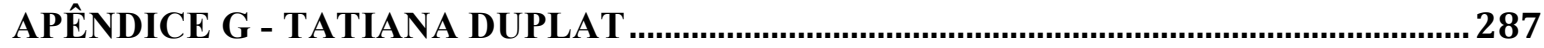

APENDICE H - ALEXANDRA FALLA ZERRATE 


\section{APRESENTAÇÃO}

\section{Inquietude}

Esse olhar inquisitivo que me dirige às vezes nosso próprio cão...

Que quer ele saber quer eu não sei responder?

Sou desse jeito... Vivo cercado de interrogações.

Dinheiro que eu tenha, como vou gastá-lo?

E como fazer para que não me esqueças?

(ou eu não te esqueça...)

Sinto-me assim, sem motivo algum,

Como alguém que estivesse comendo uma empada de camarão sem

camarões

Num velório sem defunto..

(QUINTANA, Mario, 1990, p.11)

Inicio este relato com o poema do querido amigo Mario Quintana pelo que ele representou, como aprendizado e afeto, em um momento especial de minha vida. Recebi o convite do poeta para que escrevesse a orelha de seu livro Velório sem defunto ${ }^{1}$ que, entre 72 poemas, incluía Inquietude, transcrito na epígrafe acima e que deu origem ao título do livro. Aceitei a tarefa depois de alguma resistência, pelo temor de decepcionar aquele amigo sempre afetuoso, humorado e surpreendente. Eram assim nossos encontros: Mario sempre me surpreendia, com sua ironia e lirismo, sua visão do mundo e do cotidiano. Em nossos encontros inicialmente diários e depois de até duas ou três vezes por semana, ele mostrava as últimas criações normalmente escritas no decorrer da noite, no "torpor do sono", e recitava com a voz pausada e ritmada para marcar a força de seus versos.

Quando finalmente me encorajei a escrever, depois de alguns telefonemas que recebi do amigo insistindo para que eu aceitasse, fui ao seu encontro para entender o que representava o Velório sem defunto, embora o poema Inquietude, na página 11, já destacasse, em alguns versos, uma espécie de ausência. Nesse encontro, Mario se referiu ao sentimento de insatisfação do poeta quando relê seus poemas. Sempre há o que mudar. Palavras, construções... voltei para casa, mergulhei no livro e rememorei nossa conversa.

Escrevi uma proposta de texto e voltei ao poeta para que ele lesse e fizesse suas críticas. Afinal, éramos muito amigos e eu, uma simples e assídua leitora, não desejava desapontá-lo com uma possível pieguice.

\footnotetext{
${ }^{1}$ QUINTANA, MARIO. Velório sem defunto. Porto Alegre: Mercado Aberto, 1990.
} 
Mario leu, me olhou, e disse:

- Está tudo muito bom, mas tem um problema.

A certa altura do texto escrevi que o Velório sem defunto representava a insatisfação que persegue os homens das artes e das ciências.

Calma e pacientemente, percebendo minha aflição, ele falou:

- Tem um equívoco. A insatisfação que persegue o homem das artes, das letras, não acontece com o cientista. Este, quando comprova um feito, quando conclui uma pesquisa ou um experimento, não tem insatisfação. Ele chega a um resultado. E se satisfaz...

Voltei para casa, ajustei o texto conforme a aula que mais uma vez tinha recebido daquele expert das palavras, das rimas e dos sentidos das "coisas simples". A orelha foi impressa no Velório sem defunto, lançado em 1990, mais uma vez com a singularidade que era característica do Mario. O livro foi publicado com os "poemas deitados, para não cortar os versos". E, como sempre, com o humor que acompanhava suas palavas:

- É também para que o leitor possa ler deitado, brincou o Mario.

Esse era o poeta e esse aprendizado no convívio apliquei ao longo da pesquisa para esta tese que não se conclui, que guarda ausências pela falta - "dos camarões", "do defunto" e que continuará provocando novas reflexões, assim como o poeta seguiu até sua despedida, buscando preencher os vazios, consciente de que a insatisfação era sua companheira. A busca da perfeição, para ele não alcançada, era insistir em escrever, reescrever, reeditar os versos que lhe davam a prévia satisfação. Mas, adiante, ele voltaria a mexer.

Essa sensação que tenho agora com a tese, de insatisfação pelo sentimento de vazios e ausências, pela vontade de reescrever ou começar tudo outra vez, foi manifestada de outra forma e em outro sentido por Jorge Luis Borges (com quem Mario trocou identidades e por quem nutria admiração) em uma aula magna que proferiu na Facultad de Psicología de la Universidad de Buenos Aires (UBA) em 12 de setembro de 1984, como transcrevo a seguir:

(...) yo le pregunté una vez a Alfonso Reyes ${ }^{2}$ por qué publicaba; él me dijo: "Yo me he hecho la misma pregunta y he llegado a la solución”; “¿cuál es?”,

\footnotetext{
${ }^{2}$ Alfonso Reyes (Monterrey, Nuevo León,17 de maio de 1889 — Cidade do México, 27 de dezembro de 1959) foi um poeta, ensaísta, tradutor, diplomata e pensador mexicano. Conforme informações de El Colegio Nacional, entre 1924 a 1939, Reyes viveu na França, Argentina e Brasil, como diplomata. Na Argentina, incentivou o trabalho do então jovem Jorge Luis Borges (1899-1986), que submeteu à sua apreciação o manuscrito El Aleph. Borges confessaria sua admiração ao poeta pelo resto da vida. Disponível em: $<$ https://es.wikipedia.org/wiki/Alfonso Reyes Ochoa $>$

$<$ http://www.eluniversal.com.mx/articulo/cultura/letras/2017/05/17/alfonso-reyes-impulsor-del-joven-jorge-luisborges $>$. Acesso em em 7 jun. 2017.
} 
dije yo; "publicamos para no pasarnos la vida corrigiendo los borradores". Publico un libro, que sea un fracaso no importa, yo publico un libro, mis amigos saben que no tienen que hablarme de él, y yo no sé si ese libro se ha vendido o no, eso corre por cuenta de terceros o editores, no de escritores. Como decía Kipling, "El éxito y el fracaso son dos impostores", nadie fracasa tanto como cree, ni tiene tanto éxito. Y ya el hecho de trabajar es una felicidad. Yo escribo una página mediocre, pero ya el hecho de escribir me justifica del algún modo, es decir yo cumplo con esa misteriosa tarea de escritor, con ese deber, que no sé quién me ha impuesto, o que yo mismo me he impuesto, y me siento justificado por lo menos mientras escribo, después me siento injustificado o un poco asombrado de lo escrito. ${ }^{3}$

Não tenho a pretensão de comparar-me a esses grandes escritores. Sinto um certo alívio em compartilhar seus sentimentos com o ato de narrar, o que me conforta neste momento de conclusão da tese. Com a humildade de jornalista que continua aprendendo e como pesquisadora que busca preencher as lacunas e entender os acontecimentos com a consciência de que "o acontecimento nunca está realmente classificado nos arquivos do passado; ele pode voltar como espectro para assombrar a cena do presente e hipotecar o futuro, provocar angústia e temor ou esperança, no caso de um acontecimento feliz" (DOSSE, 2010, p. 265-266). Reconheço nessa etapa, que não se conclui, as dificuldades e sofrimentos para alcançar a compreensão e ser compreendida.

Tratei nesses três anos e meio de aprendizados - inspirada por minha orientadora Profa. Dra. Cremilda Medina e pelos mestres que trafegaram comigo nessa pequena jornada no Prolam-, de apaziguar minhas angústias como profissional que exerceu uma atividade e da qual passei a ser a pesquisadora da própria observação-experiência. Sigo com as angústias, com a cautela e distanciamento que um pesquisador deve manter de seu sujeito de estudo. Confesso que muitas vezes esqueço o distanciamento e sofro com as descontinuidades e instabilidades que afetam as emissoras públicas latino-americanas.

Assim, no primeiro capítulo, rememoramos os momentos que antecederam a criação da Empresa Brasil de Comunicação (EBC), com a incorporação da TVE Brasil, a mudança do nome para TV Brasil, a junção com a Radiobras, e os conflitos e aflições vividas pelos que ali atuavam. Também justificamos porque elegemos a Señal Colombia para esta pesquisa, em

\footnotetext{
${ }^{3}$ BORGES, Jorge Luiz. Fuente:. La Página de Tomas Abraham <http://tomabra.wordpress.com/> .Disponível em: <http://oyeborges.blogspot.com.br/2010/05/dialogo-con-borges-en-la-facultad-de.html>. Acesso em 7 jun.2017.
} 
que procuramos apresentar as duas realidades, independente de comparações e analogias, com ênfase nas similaridades e diferenças.

O capítulo 2 faz um breve percurso pela noção de TV pública com ajuda de autores e especialistas que se debruçaram no estudo da "televisão pública", um significado em disputa (BUCCI, 2016 ${ }^{4}$ ). Também descrevemos os acontecimentos políticos que atingiram a EBC após o processo de impeachment da presidente Dilma Roussef, em 2016, e seus desdobramentos. Encerramos este capítulo com breve descrição de como transcorreu o processo colombiano e as mudanças que atingiram a Señal Colombia a partir de 2004, ou seja, três anos antes da criação da EBC em 2007.

O terceiro capítulo percorre a história da Televisão Nacional da Colombia, a primeira emissora surgida no país em 1954, que já nasce como uma emissora governamental, desejando ser vista como uma emissora pública. Percorremos esse caminho até o surgimento da Señal Colombia, em 2004, emissora gerida pela RTVC - Radio Televisión de Colombia Sistema de Medios Públicos, que também passou por transformações, descontinuidades e uma recriação, com formato jurídico bastante distinto. Procuramos traçar uma retrospectiva de sua história, com depoimentos de protagonistas e ajuda da bibliografia.

A TV Brasil - emissora da Empresa Brasil de Comunicação - é o tema central do capítulo 4, no qual procuramos resgatar um caminho de retorno sobre as descontinuidades que perseguiram e continuam perseguindo essas emissoras que se apresentam como públicas, educativas e culturais.

A propósito, o capítulo 5 introduz reflexões sobre o uso desses termos - públicas, educativas e culturais - por essas emissoras. Procuramos trabalhar essas noções, apontando acertos e desacertos no emprego de palavras que terão significados distintos na rotina dessas instituições (ou televisões).

Sem a pretensão de se constituir como verdade, mas como diagnóstico, esta pesquisa procurou resgatar momentos vividos na prática do trabalho, desde o início pensada em um projeto de pesquisa posterior. O sentido de observação-experiência ${ }^{5}$ me acompanhou nos dois anos da pesquisa para os livros TVE - cenas de uma história, e Rádio MEC-herança de um sonho, e nos quatro anos em que testemunhei a criação, implantação e os primeiros momentos de afirmação da TV Brasil/EBC, como a primeira emissora pública nacional.

\footnotetext{
${ }^{4}$ Um "significante em disputa" foi a expressão usada por Eugênio Bucci, durante meu exame de qualificação, em 14 Abr. 2016.

${ }^{5}$ MEDINA, Cremilda. Ato presencial. São Paulo: Casa da Serra, 2016.
} 
Como referi na dissertação de Mestrado (2005, ECA/USP), também desta vez tratei de trazer para o debate questões vividas em um ambiente de trabalho. Se a experiência é o que nos acontece, e se o sujeito da experiência é um território de passagem, então a experiência é uma paixão, porque, de acordo com Jorge Larrosa (2001) não se capta a experiência a partir de uma lógica da ação, a partir de uma reflexão do sujeito sobre si mesmo enquanto sujeito agente, mas a partir da lógica da paixão. Só a paixão nos torna pacientes para o viver, o suportar, o aceitar ou assumir o compromisso de estarmos no mundo para contribuir e reconstruir processos. ${ }^{6}$

O aprendizado alcançado até aqui e transformado em narrativa não foi exclusivo da experiência vivida, mas das trocas permitidas ao longo do convívio nesta caminhada acadêmica, com minha orientadora, meus mestres e colegas, e com a bibliografia. Sempre tendo presente o que já lembrei em outras oportunidades, nutrir-me da sabedoria de "sábios" que passam pelo nosso caminho. Entre esses, recordo aqui Paulo Freire com quem tive rápido convívio intermediado pela Profa. Dra. Olgair Garcia, uma fiel companheira de sua obra, privilegiada pelo convívio com o maior dos mestres. Com nostalgia pela sua ausência, reproduzo um dos saberes que herdei de Paulo Freire:

$\mathrm{O}$ fato de me perceber no mundo, com o mundo e com os outros me põe numa posição em face do mundo que não é a de quem nada tem a ver com ele. Afinal, minha presença no mundo não é a de quem a ele se adapta, mas de quem nele se insere. É a posição de quem luta para não ser apenas "objeto", mas sujeito também da História. ${ }^{7}$

O que narraremos a partir de agora é uma tentativa de revelar, propor e desvendar os mistérios e obstáculos que insistem em adiar a desejada televisão pública autônoma, isenta e independente.

\footnotetext{
${ }^{6}$ LARROSA, Jorge, Conferência proferida no I Seminário Internacional de Educação em Campinas, IEL, Unicampl, em 15 jul. 2001.

${ }^{7}$ FREIRE, 1997, p.60.
} 


\section{Memória e presente de duas TVs públicas na América Latina}

Pela visão de mundo passam ideologias e paradigmas, mas a inquietude de vida não se acomoda nem na certeza ideológica nem na promessa da razão científica. ${ }^{8}$ (MEDINA, 2003, p.80)

Iniciamos o percurso desta tese com uma pequena volta aos momentos que antecederam a criação da Empresa Brasil de Comunicação (EBC), e às razões pelas quais escolhi a Señal Colombia para este estudo.

Em 2007, ao concluir os livros TVE - Cenas de Uma História e Rádio MEC - Herança de um sonho - recebi o convite de Beth (Elizabeth) Carmona Leite, então presidente da Associação de Comunicação Educativa Roquette-Pinto (ACERP), mantenedora da TVE Brasil e das Rádios MEC AM e FM, para assumir a gerência executiva das Rádios MEC. Naquele momento eu estava profundamente envolvida com o que encontrara em minhas pesquisas sobre as rádios MEC e TVE Brasil e sobre a figura de Edgard Roquette-Pinto e sua paixão pelo rádio, pela educação e pela cultura. O convite de Beth Carmona me dava a chance de viver o presente de uma história com a qual tinha me envolvido muito e da qual passei a fazer parte.

A pesquisa para elaboração dos livros me permitiu ouvir protagonistas que passaram pelas instituições, vasculhar arquivos, museus, depósitos de materiais, bibliotecas e o arquivo morto situado na Penha, zona Norte do Rio de Janeiro, onde depositavam equipamentos obsoletos, documentos que deviam ser preservados, de acordo com a legislação, e já amarelados pelo tempo, mas que aguardavam uma organização e seleção arquivística. Esse trabalho acabou me estimulando para desenvolver projetos de preservação, para a instituição na área de pesquisa e acervo. Entre os documentos encontrei fichas funcionais de servidores, relatórios financeiros, ofícios sobre assuntos administrativos, material de produção e programação, entre outras preciosidades.

Vivi a rotina da ACERP como gerente executiva das Rádios MEC, mas mais do que aquela atividade, eu havia mergulhado em seu passado, convivido durante os dois anos

\footnotetext{
${ }^{8}$ MEDINA, Cremilda. A Arte de tecer o presente - Narrativa e Cotidiano. São Paulo, Editora Summus, 2003, p. 80 .
} 
dedicados à pesquisa com profissionais que atuavam nas mais distintas funções das três emissoras - TVE e Rádios MEC (AM e FM). Vasculhei os arquivos desde os que guardavam roteiros de programação, relatórios de atividades, atas de reuniões do conselho, arquivo de programas, filmes e fotos. O acervo fotográfico, que era imenso, atendeu durante o tempo em que muitas notícias e programas se ancoravam nos slides a partir de fotos; embora bastante desorganizado, reunia material dos tempos de Gilson Amado, o criador da TVE. Todos os programas possuíam fotos, algumas com resquícios da fita durex que era usada para prender as fotos na "tapadeira" em frente às câmeras. Ali encontrei preciosidades que ilustraram os dois livros que escrevi. Era um passado com altos e baixos, construções e desconstruções, que deviam ser percebidas para se evitar repetições de equívocos, como a forma de escolha de gestores.

Durante minha pesquisa, além do convívio com os que ainda atuavam na TVE, fui ouvir profissionais que já estavam afastados e que tinham tido importante papel na estruturação da TV, entre eles, Geraldo Casé, criador do Sítio do Picapau Amarelo ${ }^{9}$, que começou na TVE e, depois de uma parceria feita com a TV Globo, acabou sendo contratado por aquela emissora. Com ele foram outros profissionais que tinham ajudado Gilson Amado nos primórdios da Fundação Centro Brasileiro de TV Educativa (1967-1981).

Caminhando em meio às prateleiras de metal, no Depósito da Penha, que guardavam arquivos menores, do tamanho de meia lauda (meia folha A4), recolhi aleatoriamente alguns documentos, para verificar o que continham. E a surpresa: eram telegramas expedidos pelo Departamento Nacional de Propaganda (DNP) enviados à Rádio MEC nos anos 1930, e do órgão que o sucedeu, o Departamento de Imprensa e Propaganda (DIP), dos anos $1940^{10}$, com determinações e proibições para as emissoras de rádio. Esses telegramas eram assinados por Lourival Fontes, diretor do antigo DNP e do DIP. As determinações referiam-se à obrigatoriedade de transmissões dos discursos do presidente da República, Getúlio Vargas, de apresentações de música brasileira, de cantoras líricas, como Bidu Sayão e, entre as

\footnotetext{
${ }^{9}$ A TVE intensificava, com aquela equipe, a produção de programas infantis olhando para as raízes históricas e culturais do país, desprendendo-se dos formatos importados. (Ver mais em MILANEZ, 2007)

${ }^{10}$ Criado em 1939, no Estado Novo de Getúlio Vargas, o Departamento de Imprensa e Propaganda (DIP) tinha como objetivo ampliar as atividades do Departamento Nacional de Propaganda, que havia sido criado também no Governo Vargas, em 1938, originado do Departamento de Propaganda e Difusão Cultural (DPDC) de 1934. Foi mantido na direção geral Lourival Fontes. $<$ http://cpdoc.fgv.br/producao/dossies/FatosImagens/DIP>. Acesso em 25 out. 2016.
} 
proibições, um telegrama enviado durante a Segunda Guerra Mundial, com recomendações para não veicular música italiana e alemã (Cf MILANEZ, 2007).

Assumir o cargo para o qual Beth Carmona me convidara era abandonar o passado, naquele ano de 2007, para viver o presente das rádios MEC, com os mesmos compromissos educativos e culturais defendidos por Roquette-Pinto na fundação da Rádio Sociedade (1924) e no momento da doação desta rádio ao então Ministério da Educação e Saúde (1936), sob gestão de Gustavo Capanema. Carlos Drumond de Andrade era o chefe de gabinete do ministro. Esse passado já aí começava poético.

$\mathrm{Na}$ busca de documentos antigos, encontrei também uma troca de bilhetes entre Drumond e Roquette, não em poesia, mas afetuosos. Roquette, é bem verdade, atrevia-se na arte da poesia, como ao escrever um editorial poético em homenagem ao rádio, publicado na primeira edição da revista Electron ${ }^{11}$, que iniciava assim: "Vivo na lasca de carvão, negro e humilde, escravo do homem a cumprir os seus desejos; vivo na centelha do céu, que ensinou o fogo à humanidade...”.

Foi com este espírito que assumiria, em $2007^{12}$, no Rio de Janeiro, o cargo de gerente executiva das Rádios MEC, que ocupei até dezembro de 2011, e de onde saí triste e desanimada com o desfecho que a criação da EBC teria a partir de 2008, como veremos a seguir.

\subsection{Um olhar para a vizinhança}

Mas buscar entender o que se passava com a TV pública no Brasil não bastava. Escolhi ampliar o caminho de estudos ingressando no Programa de Pós-Graduação Integração da América Latina - PROLAM/USP, que me dava a oportunidade de estudar emissoras do nosso continente, não com a perspectiva de comparações, mas de entendimento das diferenças e semelhanças. Pela aproximação com o Midiativa - Centro de Mídia para Crianças e Adolescentes, dedicado à promoção e produção de conteúdos digitais, interativos e

\footnotetext{
${ }^{11}$ Dirigida por Roquette-Pinto, a revista Electron foi lançada em 1/1/1926, com tiragem de três mil exemplares. (MILANEZ, 2007).

${ }^{12}$ Pouco antes do lançamento dos livros Rádio MED, Herança de um Sonho, e TVE Brasil, Cenas de uma História, em um evento na sede da ACERP no Rio de Janeiro, com a presença do Ministro Franklin Martins (Secom), dirigentes de TVs públicas, ministros, autoridades e convidados especiais como Fernanda Montenegro, que fazia parte da história da Rádio MEC, entre outras personalidades.
} 
audiovisuais de qualidade para crianças e adolescentes e criador do comKids ${ }^{13}$, acompanhei alguns eventos dirigidos a profissionais, crianças e educadores, entre eles, o Festival Prix Jeunesse Iberoamericano ${ }^{14}$. Essa experiência revelou as produções infantis latino-americanas e suas exibidoras destacando-se, entre elas, a Señal Colombia e Pakapaka, da Argentina. Com produções de qualidade, chamou minha atenção, em especial, a Señal Colombia, em que tive oportunidade de me aproximar de alguns profissionais e ver suas participações ao longo do evento. Tinha conhecido em 2007, no Rio de Janeiro, Patrícia Castaño, uma colombiana que participou naquele ano do III Encontro Internacional Rio Mídia, promovido pela MULTIRIO. Patrícia já tinha uma relação com Beth Carmona (ACERP) dos Encontros do INPUT e foi a grande impulsora, na Colômbia, dos debates pela televisão pública de qualidade. Hospedada na casa de Beth Carmona, juntamente com Patrícia, tive a oportunidade de me aproximar das ideias dessas duas parceiras de longa data, que partilhavam compromissos em defesa da televisão pública.

Em junho de 2011, ainda na gerência executiva da Rádio MEC no Rio, acompanhei a $5^{\text {a }}$ edição do Festival Prix Jeunesse Iberoamericano em São Paulo, que nos eventos seguintes ganharia a companhia do comKids no nome - Festival comKids - Prix Jeunesse Iberoamericano. Já de volta a São Paulo definitivamente, integrei a equipe de organização do $6^{\circ}$ Festival comKids Prix Jeunesse Iberoamericano ${ }^{15}$, em 2013, quando colaborei com a edição do catálogo, um dossiê de todas as produções finalistas. A partir dali, passei a navegar no site da Señal e acompanhar sua programação on-line. Definida a TV latino-americana que estudaria paralelamente à TV Brasil, passei a planejar a pesquisa de campo na Colômbia, o que aconteceu em novembro de 2015.

Essa pesquisa de campo sobre a Señal iniciou ainda no voo para Bogotá. Voamos durante o dia, o que facilitou o diálogo com minha vizinha de assento, a senhora Elena Perez, que retornava ao seu país depois de uma viagem pelo Brasil, onde visitou Rio de Janeiro e São Paulo. Ficou encantada com o movimento e as pessoas nas duas cidades, mas foi da última que se disse impressionada. Dona Elena contou que no Brasil todos a alertavam sobre a questão da violência, que tomasse cuidado nas ruas. Manifestou sua alegria de não ter

\footnotetext{
${ }^{13}<$ http://comkids.com.br/sobre/>

$14<$ http://comkids.com.br/prix-jeunesse-iberoamericano/>

${ }^{15}$ Esta edição do Festival recebeu mais de 200 inscrições de produções feitas na Argentina, Brasil, Chile, Venezuela, Espanha, Cuba, Colômbia, México, Uruguai e Equador. Foram selecionados como finalistas 89 produções.
} 
enfrentado nenhuma situação difícil ou qualquer contratempo. Nesse momento, ouvi seus alertas:

- Tome cuidado, Bogotá está muy peligrosa, ladrones sacam todo, de moviel a plata.

Também recomendou que não andasse de ônibus e não tomasse taxi nas "calles". $O$ seguro era chamar taxi por aplicativo. Aproveitei esse primeiro encontro com a Colômbia, ainda nos céus brasileiros, provavelmente, para perguntar-lhe sobre a Señal Colômbia. - Que referências tinha sobre o canal?

Iniciava ali minha enquete. Dona Elena foi franca ao responder.

- Não assisto, sei que é uma boa televisão, mas nunca a vejo. Acompanho mais os canais a cabo, os filmes e documentários como os do "National Geographic".

Os dias foram intensos em Bogotá e o tempo livre ficou restrito às noites acompanhando as programações da televisão, "zapiando" os oito canais públicos regionais e mais a Señal, que, naquele momento, transmitia com exclusividade, os jogos olímpicos nacionais. Não tive, assim, oportunidade de assistir a programação normal. Era aquele um momento especial para os colombianos com a realização de suas olimpíadas.

Os dias que se sucederam foram dedicados ao trabalho. Encontros diários, nos dois turnos, e em locais que me permitiram conhecer os extremos da cidade. Nos caminhos, provocava diálogos rápidos com taxistas (nas idas), com passageiros de ônibus nos retornos, e com peatonales, quando pedia alguma informação, sempre dava espaço para um prolongamento da conversa. Quando relatava o que estava fazendo em Bogotá, aproveitava a chance:

- Você assiste a Señal Colombia? Ou: Que referências você tem da Señal Colombia, de sua programação?

Quando a resposta era afirmativa, perguntava o que mais gostava. Não foram muitos os que responderam afirmativamente, e, desses, os relatos se referiam à programação infantil. - A los niños les encantan Mi señal. (Assim é chamada a programação infantil). Essas conversas ajudaram a perceber que apesar da programação de qualidade, premiada internacionalmente, a audiência parecia pequena. Minha reflexão sobre audiência tinha um ponto de partida. Como no Brasil, a TV pública nacional também na Colômbia sofria os baixos índices de audiência na concorrência com as emissoras privadas, apesar da qualidade de sua programação infantil, seus documentários e filmes. 


\subsection{Preliminares: acertos e desacertos na criação de uma empresa de comunicação pública}

Iniciavam-se em 2007 com mais intensidade as discussões para a criação de uma empresa de comunicação pública. Tema que vinha mobilizando especialistas, profissionais e estudiosos desde as décadas finais do século 20, e nos encontros de partilha de programação quando se reuniam dirigentes de rádios e TVs educativas que integravam o Sistema Nacional de TV Educativa (SINTED) e Sistema Nacional de Radiodifusão Educativa (SINRED ${ }^{16}$ ), comandados pela TVE, sediada no Rio de Janeiro. Acompanhei, quando diretora da Rádio FM Cultura, da Fundação Cultural Piratini Rádio e Televisão (1989-1991), alguns desses encontros promovidos pelo SINRED. O SINRED foi extinto em 1996, a TVE deixou de comandar sozinha a rede, depois dividida com a paulista TV Cultura, da Fundação Padre Anchieta.

Em 1998, por iniciativa da TV Cultura, foi criada a Associação Brasileira das Emissoras Públicas Educativas e Culturais ${ }^{17}$, que mantém a rede de emissoras educativas e culturais, que passaram a se denominar também públicas.

A “televisão pública” era também pauta dos encontros promovidos pelo International Public Television Screening Conferences ${ }^{18}$ (INPUT), em vários países, como o realizado no Canadá, em 2000, que resultou no livro Televisão pública: do consumidor ao cidadão, uma iniciativa do professor Omar Rincón, então da Universidad Javeriana. ${ }^{19}$ Teresa Otondo $(2012)^{20}$ narra alguns desses encontros como o II Mini- INPUT realizado em La Paz, em 2007, quando participou de uma reunião na redação do Canal 7- Empresa Nacional de Televisão da Bolívia, para discutir o papel da televisão pública. Ali, estavam tentando

\footnotetext{
${ }^{16} \mathrm{O}$ SINTED acabou se transformando em SINRED (Sistema Nacional de Radiodifusão Educativa), ato formalizado pela Portaria MEC No 344 , de 09/08/1983, cujo texto oficializava, em seu parágrafo $2^{\circ}$ do art. $3^{\circ}$ que: "A coordenação do Sistema caberá à Fundação Centro Brasileiro de TV Educativa". In Fradkin, Alexandre. Disponível em http://radiodifusaoeducativa.blogspot.com.br/. Acesso em 6 out. 2016.

${ }^{17}$ Fundada em 28 de outubro de 1998.

${ }^{18}$ International Television Public Screening Conference (INPUT), uma organização dirigida à televisão pública internacional, iniciou atividades em 1977, promovendo encontros em diferentes países para debater o serviço público de televisão de qualidade $<$ https://en.wikipedia.org/wiki/International_Public_Television_Screening_Conference $>$.

${ }^{19}$ Hoje é professor associado da Universidad de Los Andes e director do Centro de Estudios en Periodismo (CEPER), da Facultad de Artes y Humanidades da mesma universidade.
}

${ }^{20}$ OTONDO, Teresa Montero. Televisão Pública - Para quem e para quê? São Paulo, Annablume editor, 2002. 
entender se o Canal 7 era uma televisão pública ou governamental. Também essa era a questão que permeava as conversas internamente nas televisões públicas, educativas e culturais mantidas pelos Estados e Governo Federal no Brasil.

No início da gestão do presidente Luiz Inácio Lula da Silva, a então presidente da Associação de Comunicação Educativa Roquette-Pinto - ACERP, Beth Carmona, aos cinco meses de empossada no cargo $^{21}$, promoveu o Seminário Desafios da Televisão Pública ${ }^{22}$, que reuniu, no Rio de Janeiro, em junho de 2003, mais de 200 profissionais representantes de televisões educativas e culturais de todo o Brasil, além de convidados de emissoras públicas dos Estados Unidos, Inglaterra e Alemanha. O Seminário propunha uma reflexão sobre sustentabilidade e qualidade. Testemunhei esse momento como presidente da Fundação Cultural Piratini Radio e Televisão ${ }^{23}$, assim como outros representantes de televisões educativas e culturais. Partilhamos nossas angústias e constatamos que as experiências internacionais apresentadas tinham modelos diferentes, mas princípios similares aos da $\mathrm{BBC}$, considerada a mãe das emissoras públicas, com objetivos "de enriquecer a vida dos indivíduos com programas e serviços que eduquem, entretenham e também informem". ${ }^{24}$ Essa era a plataforma defendida por todos ao longo do evento.

Esse seminário serviu para os dirigentes que iniciavam juntos suas gestões se integrarem nas discussões em defesa das emissoras públicas, que já atraía a atenção do Governo Federal. Entre os palestrantes estavam Marcus Flora, secretário-adjunto da Secretaria de Governo e Gestão Estratégica da Presidência da República; Alyce Myatt, da PBS (Estados Unidos); Lúcio Mesquita, da BBC; Uwe Rosenbaum, da Südwestrundfunk

\footnotetext{
${ }^{21}$ Em entrevista realizada em 29/09/2016, perguntei à Beth Carmona quem e como havia sido formulado o convite para ela assumir a presidência da ACERP. Assim respondeu: Olha, na verdade, essa coisa de quem te indicou vai ficando muito engraçada. Eu me lembro que estava chegando em casa logo depois do Ano Novo, quando o Lula tinha assumido, tinha três, quatro ligações no meu telefone; uma era do (Ricardo) Kotscho, uma era do (Eugenio) Bucci, uma era do próprio Marcos Flora que na época era o secretário executivo do ministro (Luiz) Gushiken, então era todo mundo me chamando pra ir lá ter uma conversa, e que olha estão te chamando, olha, vai. Então assim, de onde surgiu a ideia: foi de um grupo, mas o que me falaram era que analisando as competências e tudo o que eu tinha feito até então no meu currículo eles acharam que eu era a pessoa certa. Então você foi uma escolha técnica, você não foi uma escolha política? Resposta de Beth: Desde o primeiro momento isso ficou bem claro. Para a revista Tela Viva (Dez. 2006), Carmona lembrou que quando foi chamada para assumir a direção chegou a estranhar. "Eu nem conhecia pessoalmente o Luiz Gushiken (então ministro da Secom, o (Ricardo) Korscho, a equipe de comunicação do governo. Eu dizia a eles que havia gente dentro do PT que tinha condições de assumir o posto. Mas eles disseram que eu era a pessoa certa, e insistiram para que eu viesse. Desde então, tive total liberdade para trabalhar, nunca recebi um telefonema sequer pedindo algum tipo de intervenção", contou à revista.

${ }^{22}$ O Desafio da TV Pública. Rio de Janeiro: ACERP, 2003.

${ }^{23}$ A Fundação Cultural Piratini Rádio e Televisão é mantenedora da TVE-RS e Rádio FM Cultura.

${ }^{24}$ MESQUITA, Lúcio. O Modelo da TV Pública da BBC. Em O Desafio da TV Pública, ACERP, Rio de Janeiro, 2003
} 
(SWR), sistema público de TV e Rádio da Alemanha; Nelson Hoineff, presidente da Associação Brasileira das Produtoras Independentes de TV (ABPITV); o presidente da Radiobrás, Eugenio Bucci, que também iniciava sua gestão em 2003; Gabriel Priolli, diretor da TV PUC de São Paulo; Jorge Cunha Lima, então presidente da Fundação Padre Anchieta; e Laurindo Leal Filho, da USP, entre outros especialistas brasileiros.

No decorrer daquele ano, participamos dos encontros da Associação Brasileira das Emissoras Públicas, Educativas e Culturais - ABEPEC, instituição que assumiu o papel do SINRED como organizador da rede pública de televisão, lugar onde também a TV pública e as televisões que representávamos eram debatidas, e tinham suas dificuldades expostas num exercício de troca de experiência e intercâmbio de programação. O primeiro encontro aconteceu nos dias 28, 29 e 30 de maio, em São Paulo, tendo como anfitriã a TV Cultura, presidida por Jorge Cunha Lima, também presidente da ABEPEC. Nesse XVIII Encontro da ABEPEC, foram discutidos os novos horários da grade nacional (quantas horas por dias todas as emissoras estariam em rede); programação e grade da Rede Pública; regras de Marketing; breaks nacionais; breaks regionais; verbas de patrocínio; e as discussões sobre as novas regras para a comissão de programação. Ou seja, temas que deveriam se encaixar na rotina das emissoras. Também foi aprovado o pedido de reingresso da TV Nacional (Radiobrás) como associada da ABEPEC.

O destaque na programação do terceiro dia foi a apresentação, pela Secretaria do Audiovisual do MINC, do projeto de documentários nacionais, que se chamaria DOC-TV. O Documento entregue aos presidentes de televisões públicas, que conservo em meus arquivos, informava os objetivos:

Desenvolver projeto de parceria do Ministério da Cultura junto à Rede Pública de Televisão, através de convênio firmado pela Secretaria do Audiovisual e a Fundação Padre Anchieta, visando o fomento à produção e a articulação do circuito nacional de televisão e documentários culturais; Promover a implantação de Polos Regionais de Produção de documentários, através da articulação das emissoras componentes da Rede Pública e suas afiliadas, com núcleos de realizadores e produtores independentes nos diferentes estados da federação;

Realizar carteira de 24 documentários através de 15 Polos Regionais de Produção no período 2003/2004 e promover sua difusão na Rede Pública de Televisão e emissoras afiliadas. (grifos do documento)

O projeto foi aprovado e ali já se definiu o número de documentários que seriam produzidos pelas emissoras. A avaliação da quantidade de produções por emissora fora 
determinada pelo MINC em colaboração com a TV Cultura. Percebia-se nesse encontro uma afinidade já existente entre o MINC e a Fundação Padre Anchieta (TV Cultura). O projeto que recebemos, assinado por Mario Borgneth, então Gerente de Documentários da TV Cultura $^{25}$, informava: "mapeando a dinâmica e o vigor da produção independente em cada Estado do País, foram definidas as praças para implantação inicial dos Polos de Produção e o número de projetos a serem produzidos por cada polo”. Conforme a avaliação, dois estados (Rio e São Paulo) contribuiriam com três documentários, outros, com dois, e outros com um. Cada projeto selecionado receberia um aporte de $\mathrm{R} \$ 80.000,00$ para sua produção, garantido pelo convênio MINC/FPA (Fundação Padre Anchieta). A título de contrapartida, a emissora regional faria aporte de $\mathrm{R} \$ 10.000,00$ para complementação do custo de produção. Esse montante dependeria das condições da regional, podendo ser integralizado em recursos financeiros ou insumos técnicos e serviços (equipamento, infraestrutura de produção, arquivos, etc). Esse último foi a opção possível à TVE RS, pelas condições e escassez de recursos financeiros.

A Rede Pública seria responsável pela teledifusão dos 24 documentários no ano de 2004, na faixa Doc.Brasil, para ir ao ar aos sábados, às 21 h (estreias). Também ficou definido duas reprises de cada título ao longo do ano, em horários de melhor conveniência para cada emissora. Para as emissoras esses documentários agregavam valor às suas grades, além de cumprir com a finalidade de apresentar a diversidade do País em suas programações. A coordenação geral ficou sob a responsabilidade da Secretaria do Audiovisual e da Fundação Padre Anchieta. A TV Cultura assumiu as funções de Gerência Executiva. A TVE RS FCPRTVE, a qual eu presidia, depois de seleção feita por um júri de especialistas, selecionou os dois documentários: Continente dos Viajantes, dirigido por André Constantin, e Coberta D'Alma - um ritual para os mortos, direção de Hique Montanari.

Detalho esse primeiro encontro da ABEPEC, em 2003, porque considero aquele momento o embrião dos debates sobre comunicação pública e televisão pública, já no século 21, que se intensificariam a partir dali. Percebemos naquele encontro uma aproximação importante para o Ministério da Cultura com as televisões públicas, educativas, culturais. Havia um forte interesse do setor de cinema e de produtores independentes pleiteando essa movimentação junto ao Ministério da Cultura, como narra Renata Souza em sua Tese de

\footnotetext{
${ }^{25}$ Mario Borgneth passaria, mais tarde, a assessor do MINC, depois diretor de Relacionamento e Rede da EBC, e novamente voltaria ao MINC, como secretário do Audiovisual.
} 
Doutorado $^{26}$ (2014). Outro participante importante para a administração federal naquele momento foi a Secretaria Especial de Comunicação da Presidência da República (Secom), que apresentou a "nova política de comunicação do governo federal, bem como as regras e procedimentos da propaganda institucional”.

A mobilização da ABEPEC continuou naquele ano de 2003 com um segundo encontro, desta vez em Brasília, tendo como anfitriã a Radiobrás/TV Nacional, que havia ingressado na entidade em maio daquele ano, no já citado XVIII Encontro realizado em São Paulo. O XIX Encontro se realizou nos dias 10, 11 e 12 de setembro. Além das discussões de praxe dessas reuniões, a agenda do segundo dia ficou reservada ao Seminário Internacional em Defesa da TV Pública, promovido pela Câmara Federal, tendo como foco principal a reinstalação dos trabalhos da Frente Parlamentar em Defesa da TV Pública, presidida pelo deputado Evilásio Farias (PSB-SP). Os temas giraram em torno do sistema de financiamento adotado por emissoras públicas internacionais, entre elas a $\mathrm{BBC}$, sempre o modelo mais idealizado. O segundo assunto, A programação das TVs e o Resgate da Cidadania, teve apresentação de Beth Carmona, presidente da ACERP/TVE Rede Brasil, e o terceiro painel tratou do Modelo de Gestão da TV Pública no Brasil, apresentado por Jorge Cunha Lima, então presidente da TV Cultura, com comentários de Engênio Bucci, presidente da Radiobrás, e Marilena Chiarelli, presidente da TV Senado.

Esses eventos mostram a continuidade que se dava ao debate sobre TV Pública, como uma pauta da administração federal. Os dirigentes das emissoras vinculadas ao Governo Federal debruçavam-se nos estudos e diagnóstico das suas instituições para traçarem seus planejamentos e estratégias. Testemunhei aquele trabalho pelo convívio que passamos a ter e pelo fato de também eu estar envolvida com uma instituição similar, embora com situação jurídica distinta: a TVE RS era uma fundação pública de direito privado.

\subsection{Disputas e dissabores}

Quatro anos depois, em 2007, o ambiente era outro. O entusiasmo que nos movia também era outro. Descobríamos as dificuldades de gerenciar emissoras públicas, na

\footnotetext{
${ }^{26}$ SOUZA, Renata de Paula Trindade Rocha de Souza. Políticas Culturais e Televisão Pública: o processo de conformação da Empresa Brasil de Comunicação/TV Brasil. 2014.Tese (Doutorado em Cultura e Sociedade). Programa Multidisciplinar de Pós-Graduação em Cultura e Sociedade do Instituto de Humanidades, Artes e Ciência, da Universidade Federal da Bahia.
} 
realidade muito mais governamentais do que públicas. Eu já estava afastada da presidência Fundação Cultural Piratini Rádio e Televisão desde 2004. Neste intervalo, conclui o mestrado na $\mathrm{USP}^{27}$ em 2005, e, na sequência, no final daquele ano, a convite de Beth Carmona, dei início à pesquisa sobre a história das emissoras geridas pela ACERP - TVE Brasil e Rádio MEC. Passei também a acompanhar diretamente o trabalho de gestão de Carmona à frente da ACERP paralelamente à pesquisa e imersão no passado das duas instituições. Como resultado da pesquisa, lançamos em 2007 os livros sobre a TVE Brasil e Rádio MEC (já citados). Na sequência, aceitei o convite para a assumir a gerência-executiva da Rádio MEC. E, assim, permaneci atenta e envolvida com as movimentações que giravam em torno da discussão sobre emissoras - públicas?, estatais? ou governamentais? - no País. Pública, estatal, governamental foram as três palavras que integravam a pergunta que me moveu: Por que os governos continuam a tomar de assalto essas instituições? Mas minhas inquietudes não paravam aí. Segui, assim, atenta como observadora que "experimenta, porque a observação vai além da participante da antropologia”, conforme ressalta Cremilda Medina $(2016)^{28}$.

Era perceptível para quem trabalhava na área que os conflitos observados em 2007 tinham origem na disputa pela implantação de uma televisão pública que reunisse as emissoras mantidas pelo Governo Federal que até ali atuavam de forma independente uma da outra: a Radiobrás e a ACERP. A primeira, que se origina da antiga Agência Nacional, durante muito tempo teve seu vínculo com a Casa Civil, depois com a SECOM; a segunda, a Associação de Comunicação Educativa Roquette-Pinto (ACERP), era uma organização social que gerenciava a TVE Rede Brasil e as rádios MEC AM e FM, no Rio de Janeiro - além de uma MEC AM em Brasília, e a TVE Maranhão. A ACERP mantinha contrato de gestão com a SECOM desde 1998, quando substituiu a Fundação Roquette-Pinto, durante o governo Fernando Henrique Cardoso (MILANEZ, 2007).

O universo que cercava essa disputa envolvia um vasto leque de questões que o tema da televisão pública levantava naquele momento, como foi apontado nos estudos prévios preparados pelo Conselho de Administração da ACERP e sua direção, aos quais tive acesso

\footnotetext{
${ }^{27}$ No Mestrado me dediquei ao estudo da produção de sentidos de uma televisão educativa e cultural que também se considerava pública, a TVE-RS, da FCPRTV.

${ }^{28}$ MEDINA, Cremilda. O invisível à luz da experiência e da compreensão (Prefácio) In: KÜNSCH, Dimas A. et al, (Orgs).Comunicação e Estudos e Práticas de Compreensão. São Paulo: Editora UNI, 2016. Disponível em: $<$ http://casperlibero.edu.br/wp-content/uploads/2016/12/comunicacao-e-estudo-e-praticas-de-compreensao.pdf $>$. Acesso em 15 jan. 2017.
} 
quando trabalhava na instituição. Assim como a ACERP, outros organismos desenvolviam estudos preparatórios para serem levados ao Fórum Nacional de TV'S Públicas que o Ministério da Cultura preparava para aquele ano (2007).

Os temas levantados pelo Conselho de Administração da ACERP como elementos a serem encaminhados às áreas do governo envolvidas nas discussões para a criação de uma empresa de comunicação pública, iam da legislação, passando pelas tecnologias, políticas públicas, setor produtivo (produtoras e realizadores) e sociedade. Essas áreas estavam ancoradas em diferentes ministérios. A tarefa, como apontava a então presidente da ACERP, Beth Carmona, se tornava extremamente desafiante porque devia mirar a situação presente naquele momento, "como mero transiente entre um passado em que o tema foi tratado de forma errática e fragmentada e um futuro que chegava de forma mais rápida e desintegrada do que se desejaria”. (CARMONA, Beth. 2007). Beth se referia, em um documento chamado de Motivação Geral, ao que ocorria na Administração Federal, onde o tratamento do tema era dificultado em função do envolvimento de diversos ministérios e órgãos. Tais como, a Secretaria Geral da Presidência, onde estavam, naquele momento, a Empresa Brasileira de Comunicação - Radiobrás e a Associação de Comunicação Educativa Roquette-PintoACERP; a Casa Civil, que concentrava a coordenação dos esforços relacionados à televisão digital e seus padrões; o Ministério das Comunicações, com os temas relacionados às telecomunicações e radiodifusão; o Ministério da Cultura, que abrigava as ações relacionadas aos conteúdos culturais incluindo audiovisual e a chamada indústria criativa; o Ministério da Educação, que liderava a promoção de ações e conteúdos educacionais, na modalidade a distância, entre outros. Lembro aqui que a ACERP/TVE produzia, mediante contrato, os conteúdos da TV Escola, mantida pelo Ministério da Educação.

Voltando para o início de 2003, a pesquisadora Renata de Paula Trindade Rocha de Souza recorda em sua tese de doutorado Políticas Culturais e Televisão Pública: o processo de conformação da Empresa Brasil de Comunicação/TV Brasil (2014) que, depois da posse do presidente Luiz Inácio Lula da Silva, “diversas instituições e agentes pertencentes à esfera do governo federal, no campo da cultura, passam a reclamar a pauta da televisão e consequentemente da TV pública, para além de outros agentes e instituições que historicamente acolhiam o tema" (SOUZA, 2014, p.85). Para a pesquisadora, o rosto humano do Estado ganha feições diversas com a ascensão de novos protagonistas ao processo político e da influência de uma "agenda política modernizadora" (Ibid) e com ingerência de muitos agentes: 
Tais aspectos também contribuem para o surgimento de tensões e reordenamentos na demarcação das áreas de atuação do setor audiovisual inclusive no que diz respeito à competência entre os diversos órgãos estatais. Longe de ser transparente como infundem os programas, documentos e discursos; os direcionamentos, representações e recursos empreendidos na definição de políticas para o setor são resultado de múltiplas interferências, seja de indefinições, seja dos mais diversos agentes. (SOUZA, 2014, p.85)

Nesse emaranhado, o Fórum Nacional de TV’S Públicas, preparado pelo MinC, realizado em maio de 2007, constituía uma oportunidade para que a Administração Federal consolidasse, como afirmara o documento da ACERP, uma visão global sobre o tema de forma a induzir ações integradoras de âmbito nacional, considerando as missões específicas da Radiobrás e da ACERP, as instituições em foco que dariam origem à Empresa Brasil de Comunicação (EBC). Além desses órgãos, também elaboravam estudos para o grande debate (Fórum), pesquisadores e organizações como a ABEPEC - Associação Brasileira das Emissoras Públicas, Educativas e Culturais, que congregava 19 geradoras de televisão aberta com finalidade educativa, pública e cultural; ABTU - Associação Brasileira de Televisão Universitária; ASTRAL - Associação Brasileira de Televisões e Rádios Legislativas; ABCCOM - Associação Brasileira de Canais Comunitários. Também participaram entidades da sociedade civil como FNDC - Fórum Nacional pela Democratização da Comunicação, Intervozes - Coletivo Brasil de Comunicação Social, mais os dirigentes de emissoras educativas e culturais, comunitárias, enfim, instituições do campo público que reuniam todas as concessões para emissoras educativas.

Durante o ano de 2006, por iniciativa da ACERP-TVE e governo federal, foram realizados encontros em diferentes estados, como Maranhão (onde a TVE era também gerida pela ACERP), Pará, Bahia, Pernambuco, entre outros, para refletir sobre as mudanças que estavam pela frente, a TV digital e o fim do analógico, como lembrou Beth Carmona em um contato que fiz no dia 5/12/2016. Os encontros nos Estados reuniam representantes de emissoras públicas, representantes da Presidência da República, de profissionais, acadêmicos e especialistas, com o objetivo de apresentar e debater as concepções/propostas do setor governamental para a TV Pública, a partir da discussão maior do papel da televisão pública no Brasil.

Esse acúmulo de discussões e resoluções foram preparatórias para o Fórum Nacional das TV’S Públicas. A Secretaria de Comunicação de Governo e Gestão Estratégica 
$\left(\mathrm{SECOM}^{29}\right)$, com a saída do ministro Luiz Gushiken ${ }^{30}$, ficara sob atribuição do secretariogeral da Presidência, Luiz Dulci, que acumulou as funções. Com a nomeação do ministro Franklin Martins, em 2007, a SECOM retomou todas as suas atividades e o novo ministro seria então um importante agente para a criação da nova comunicação pública, incluindo o tema TV pública.

\subsection{No interior das organizações, angústia e expectativa}

Os momentos que antecederam a criação da Empresa Brasil de Comunicação, em 2007, além de frutíferos, em virtude das reflexões, proposições e diagnósticos que chegavam com a intenção de municiar a administração federal de informações, eram também aflitivos para os que dentro das instituições assistiam àquela movimentação e que tinham incertezas quanto às ideias que prevaleceriam, como seria constituída a anunciada emissora pública nacional, e a que órgão ela ficaria vinculada. Jorge Cunha Lima, então presidente da ABEPEC, descreveu em seu blog, no IG, no dia 13/03/2007, reproduzido no Observatório da Imprensa ${ }^{31}$, o clima naquele momento. "Televisão pública em pé de guerra" foi o título dado à nota que descreve os conflitos entre os ministros:

Há uma dissonância profunda com relação à Televisão Pública no Governo Federal. Por um lado, Gilberto Gil, Ministro da Cultura, com o conhecimento e aparente consentimento da Casa Civil, do Gabinete da Presidência, do Ministério das Comunicações, e todas as sociedades representativas das televisões que gravitam no campo da televisão pública no Brasil, convoca um grande Fórum para discutir a questão da TV Pública. O Fórum está funcionando há mais de cinco meses e já produziu magníficos diagnósticos e documentos que serão finalmente discutidos no evento final do Fórum a ser realizado em Abril. Do outro lado o Ministro Hélio Costa em entrevistas aos jornais O Globo e Estadão anuncia a criação de uma Rede

\footnotetext{
${ }^{29}$ Assim era chamada a Secom em 2005 - 2007. Vale um parentese: a Secom foi criada em 1979, sob a direção do ministro Said Farhat, como um "organismo que pretende unificar a política de comunicacão de todos os Estados, conforme noticiado pelo O Estado de S. Paulo, em 22 de abril de 1979 (CF. MEDINA, 1982, p. 270).

${ }^{30}$ O presidente Luiz Inácio Lula da Silva transferiu o secretário de Comunicação, Luiz Gushiken, para a chefia do Núcleo de Assuntos Estratégicos na Presidência, onde será assessor especial. A SECOM passa a ser responsabilidade da Secretaria Geral da Presidência, do ministro Luiz Dulci, que também comanda a pasta da Secretaria de Direitos Humanos. Portal Imprensa, 22/07/2005. Disponível em: $<$ http://portalimprensa.com.br/noticias/ultimas noticias/4340/gushiken+deixa+a+chefia + da + secretaria + de + com unicacao $>$. Acesso em 25 out. 2016.

31 Disponível em: $<$ http://jorgedacunhalima.ig.com.br/?s=O+governo + federal $+\mathrm{e}+\mathrm{a}+\mathrm{tv}+\mathrm{p} \% \mathrm{C} 3 \% \mathrm{BAblica}>$. Acesso em 14 jun. 2015.
} 
Pública de Televisão (estatal), analógica, nacional, que transmitirá notícias do governo para todo o país. (Grifo nosso)

Cunha Lima citava, como justificativa dada pelo ministro Costa para a criação dessa empresa, o fato sempre alegado "da má cobertura feita pelos veículos de comunicação privados e mesmo pelos veículos estatais como a Radiobrás”. O presidente da ABEPEC, Cunha Lima, colocava mais lenha na fogueira ministerial: "Costa adverte que a rede seria menos chapa branca do que a Radiobrás. Tal entendimento é de difícil compreensão, mesmo para um profissional. Na verdade, o governo está dividido". E narrava os desejos de cada grupo: "Uns querem aparelhar o Estado com um instrumento de comunicação poderoso, como aliás já anunciou o partido, em recente manifestação. Outros querem construir uma televisão pública, sólida e independente. Só esquecem que há lugar para tudo".

Havia sentido nas críticas de Jorge Cunha Lima. Como eu vinha acompanhando todo o processo, depois de imergir na história das emissoras vinculadas à ACERP, e de presidir uma emissora pública, educativa e cultural (assim se classificava a TVE-RS, da Fundação Cultural Piratini Rádio e Televisão), concordava com ele de que já existia "uma rede pública, na letra e no espírito da Constituição que só não é muito melhor porque o Governo Federal não ajuda em nada”. Segundo o presidente Cunha Lima, havia espaço constitucional para a existência de televisões dos poderes do Estado, legislativas, judiciárias e executivas e elas já estavam funcionando. Lembrava ainda que, de acordo com a Constituição, já contávamos com televisões privadas, comerciais e que não "havia menor necessidade de inventar moda". Bastava qualificar o que já existia para que a Constituição fosse cumprida. Isso era o que pleiteavam dirigentes de emissoras educativas e culturais nos encontros da ABEPEC. Posição diferente dos articuladores políticos que acabaram criando uma empresa com duas heranças difíceis (situações administrativas, quadro funcional com institutos jurídicos distintos, programações, históricos de produção e operação também completamente diferentes), com conflitos que se arrastariam por um bom tempo, e com custos muito mais elevados. Entre esses articuladores estavam o grupo da cultura (MinC), liderados pelo ministro Gilberto Gil, Orlando Senna, o secretário do Audiovisual entre outros, e o grupo que se articulava com um ministro que chegava, Franklin Martins, na SECOM, nominado grupo dos jornalistas, entre outros.

No dia 5 de janeiro de 2006, antes da coluna de Jorge Cunha Lima, o FNDC divulgou em seu site uma nota com o título "Em vôo solo, ministro planeja rede estatal de televisão". O 
texto, redigido por Ana Rita Marini ${ }^{32}$ (Redação FNDC), demonstrava surpresa com anúncio do ministro Hélio Costa:

Desconsiderando o trabalho que vem sendo realizado por diversas entidades da sociedade e representantes do próprio governo federal no Fórum de TVs Públicas, o ministro Hélio Costa anunciou esta semana que a rede seria montada com os canais vagos a partir da implantação da TV digital no País.

A nota era mais uma crítica às declarações de Hélio Costa e as repercussões sobre a manifestações do ministro continuaram. Em 28 de março de 2007, o Ministro das Comunicações, a convite da Comissão de Ciência e Tecnologia da Câmara dos Deputados, debateu "durante mais de três horas as ideias sobre a criação de uma nova rede de televisão estatal (ou pública)," acrescentava entre parênteses a nota redigida por Carlos Eduardo Zanatta, da Tela Viva, publicada no site do FNDC. ${ }^{33}$ Segundo Zanatta, apesar da presença maciça dos deputados da Comissão e da participação de mais de 30 deputados que fizeram intervenções, o debate com o ministro não avançou. "Ao contrário, permanecem as dúvidas conceituais acerca da diferenciação entre TV estatal e TV pública". Deixavam de fora das discussões o que na realidade se anunciava, uma TV governamental. Em resposta a alguns questionamenos, Hélio Costa respondeu que sua missão na questão da TV estatal/pública estava exclusivamente relacionada à parte técnica, mas não deixou de falar sobre o conteúdo da nova TV:

\begin{abstract}
"Eu conversei longamente com o ministro Luiz Dulci sobre o assunto. A nova TV não será para divulgar os atos do governo, mas para fazer aquilo que as TVs comerciais não fazem. Por exemplo, não vi até agora nas TVs comerciais nenhuma discussão mais profunda sobre biodiesel no horário nobre. Eu sei que isso não é feito porque não cabe em uma TV comercial. Mas cabe em uma TV pública".
\end{abstract}

Questionado se a proposta de criação da TV estatal/pública não estaria atropelando a discussão conduzida por outros órgãos do governo com a participação da sociedade sobre o futuro das TVs públicas no País, o ministro rejeitou as "insinuações a respeito". Costa continuou sua peregrinação. Em 11/04/2007, participou de uma audiência pública na

\footnotetext{
${ }^{32}$ Disponível em: <http://fndc.org.br/noticias/em-voo-solo-ministro-planeja-rede-estatal-de-televisao-121484/>. Acesso em 5 out. 2016.

${ }^{33}$ Disponível em: < http://fndc.org.br/clipping/helio-costa-debate-tv-publica-ou-estatal-na-camara-145312/>. Publicado em 29 fev. 2007. Acesso em 10 out. 2016.
} 
Comissão de Comunicação do Senado. Conforme nota publicada no site do FNDC $^{34}$ o ministro afirmou enfaticamente sua visão sobre a TV Pública:

Queremos que tudo que a elite vê no cabo o povão possa ver na TV aberta. Será que é pedir demais? Não estamos propondo um modelo estatal de canais. Estamos propondo, e temos viabilidade técnica para isso, ter quatro canais que podem ser usados pela sociedade. Não vamos competir com as TVs comerciais, a cabo ou educativas.

No Senado, o ministro informou que encaminharia ao presidente da República, nas semanas seguintes, texto com propostas de políticas públicas de comunicações, "que servirá como base para a elaboração das políticas do setor nos próximos quatro anos”. Comunicou a formação de um grupo de trabalho que iria definir o funcionamento da TV pública no Brasil, e que o novo sistema teria quatro canais: um destinado à educação, outro à cultura e um terceiro à cidadania. Já "o quarto canal deverá ser uma versão aprimorada do que veicula hoje a Radiobrás, com mais estrutura e recursos técnicos". Neste momento, Costa interferia indiretamente na empresa dirigida por Eugênio Bucci.

Essas manifestações do ministro Hélio Costa repercutiram negativamente. Costa foi o terceiro ministro a comandar a pasta, que iniciou o Governo Lula com o deputado federal Miro Teixeira (ex PDT-RJ), substituído, em 2004, pelo deputado Eunício Oliveira (PMDBCE). Conhecido pelo setor como Minicom, o Ministério das Comunicações "tem sido considerado como moeda de troca na história dos governos pós redemocratização”, escreveu Jonas Valente, do Intervozes, em 04/10/2015. ${ }^{35}$

Gabriel Priolli, então presidente da Associação Brasileira de Televisões Universitárias (ABTU), também escreveu sobre a movimentação na administração federal, com a mesma linha de Jorge da Cunha Lima. Priolli interpretou o momento com um artigo publicado pela revista $\mathrm{Cult}^{36}$ que recebeu o título A TV Pública é importante? O presidente da ABTU abria o texto com perguntas que estavam na ordem do dia da imprensa: "valia a pena o Estado gastar

\footnotetext{
${ }^{34}<$ http://www.fndc.org.br/clipping/helio-costa-fala-sobre-tv-publica-no-senado-148372/>. Publicado em 11 abr. 2007. Acessado em 10 out. 2016.

${ }^{35}$ Do Coletivo Intervozes - publicado 4 out. 2015, em $<$ http://www.cartacapital.com.br/blogs/intervozes/ministerio-das-comunicacoes-moeda-de-troca-evidencia-faltade-politica-5992.html>. Acesso em 13 dez. 2016.

${ }^{36}$ PRIOLLI, Gabriel. A TV pública é importante? Revista Cult, São Paulo, 2007.

$<$ http://revistacult.uol.com.br/home/2010/03/a-tv-publica-e-importante/>. Acesso em 13 dez. 2016
} 
dinheiro na montagem de um sistema público de televisão, considerando as carências que o País enfrentava?; esse gasto não ficava ainda mais injustificado, ao se olhar para a baixa audiência dessa TV pública?; reformar essa TV pública, para que fique atraente e aumente a audiência, não interessa apenas ao governo - ou ao presidente Lula, no caso - para promovêlo?". E mais, Priolli reproduziu o que a mídia mais formulava: "Não é melhor termos apenas canais comerciais, que são pagos pela publicidade privada e não oneram demasiadamente o Estado?".

O presidente da ABTU, Gabriel Priolli, lembrou que essas e "outras questões correlatas" entraram no debate, desde a manifestação do ministro das Comunicações, Hélio Costa, em fevereiro daquele ano (2007), relativa ao desenvolvimento de um projeto de uma rede pública de televisão, a pedido do presidente da República. Segundo Priolli, o ministro Costa estimava preliminarmente o custo de implantação do projeto governamental em $\mathrm{R} \$ 250$ milhões. Priolli tratou ainda do impacto que o anúncio de Costa provocou nos canais privados, que logo enxergaram na nova rede "um ralo pelo qual escoariam os recursos financeiros a ela destinados na forma de publicidade estatal". O texto seguiu com uma defesa contundente da TV pública respondendo à pergunta do título:

Analisando em profundidade a televisão brasileira e suas conexões com a
vida social, econômica e política, a resposta é clara e objetiva: sim, a TV
pública é importante. Mais que isso, ela é indispensável. E não se trata
apenas de construir uma rede de televisão federal, sob controle do Poder
Executivo, mas de promover uma ampla reforma de todo o sistema público e
estatal de TV, que transcende em muito o projeto do governo Lula e pode
desempenhar um papel decisivo para o aperfeiçoamento e a democratização
da comunicação eletrônica em nosso país. (PRIOLLI, 2007)

A afirmação feita pelo ministro Hélio $\operatorname{Costa}^{37}$ no dia 13/03/2007, de que havia apresentado ao presidente Lula um projeto de criação de uma Rede Nacional de Televisão Pública também provocou indignação em alguns setores do governo, principalmente no Ministério da Cultura que já vinha preparando o Fórum Nacional de TVS Públicas. Mas Costa continuou tratando do tema. Em 04/04/2007, o ministro anunciou durante audiência na Comissão de Ciência, Tecnologia, Inovação, Comunicação e Informática $(\mathrm{CCT})^{38}$, do Senado,

\footnotetext{
37 Disponível em: $<$ http://politica.estadao.com.br/noticias/geral,lula-e-ministros-discutirao-rede-publica-detv,20070313p28169>. Acesso em 13 nov. 2016. $38<$ https://www12.senado.leg.br/noticias/materias/2007/04/04/helio-costa-anuncia-grupo-de-trabalho-para-
definir-funcionamento-de-tv-publica>.
} 
a formação de um grupo de trabalho para definir o funcionamento da TV pública no Brasil, sem fazer referências aos estudos do MinC.

As notícias sobre desencontros entre ministérios em torno do tema televisão pública se espalharam pelo Brasil. Nota da Agência Brasil, reproduzida pelo site da Tribuna do Paraná ${ }^{39}$ em 21/03/2007, informou na abertura que:

O ministro das Comunicações, Hélio Costa, usou a discussão da TV pública para alfinetar o Ministério da Cultura cujos principais técnicos vêm apresentando restrições à criação da Rede Nacional de TV Pública. A proposta, segundo Costa, não abordou a questão do conteúdo do canal. "Não disse se é para mostrar a cara do presidente, se é para mostrar o programa A ou B. Quem se intitula em querer falar de TV pública, e eu não sei quem lhe deu essa delegação, é o Ministério da Cultura. Quando quiser falar de TV pública agora pergunte ao ministro Gilberto Gil, não é mais comigo", completou.

Com essa declaração, o ministro abandonava o "páreo". Em meio a desencontros ministeriais, os profissionais que atuavam nos veículos da ACERP viviam entre duas possibilidades: 1- melhoria dos canais existentes, com recursos para investimentos e fortalecimento da rede pública de televisão, ou o desmantelamento, com a fusão de duas instituições completamente diferentes na sua origem e nas suas atribuições. Uma estatal reconhecida como prestadora de um serviço ao governo e uma organização social um pouco mais independente, embora financiada com recursos da Administração Federal; 2 - juntar as duas instituições e aumentar os recursos, com foco nos ganhos, sem pensar muito nas perdas. A ACERP tinha investido na qualificação de sua grade e de seus profissionais, avançado em termos de estrutura física e resolvido inúmeras pendências como corroboram os relatórios de gestão $^{40}$, incluindo a parte relativa às rádios como testemunhei quando gerente-executiva. Renata Souza (2014) destacou em sua tese um trecho do relatório de gestão da ACERP, de 2006, com avaliação de Beth Carmona, e que reproduzo aqui:

Resolvemos inúmeras pendências, como a renovação das dívidas, os dissídios atrasados, a reforma de instalações e a atualização profissional dos funcionários. Introduzimos novas posturas e procedimentos de trabalho. Na TVE, fizemos mudanças profundas na programação e redefinimos conceito,

\footnotetext{
39 Disponível em: <http://www.tribunapr.com.br/noticias/tv-publica-nao-e-mais-comigo-pergunte-ao-gil-dizcosta/>. Acessado em 5 out. 2016.

${ }^{40}$ Testemunhei essas realizações por participar das reuniões como gerente executiva da Rádio MEC (AM e FM) e colaborar na elaboração dos relatórios de gestão, com a parte relativa às rádios.
} 
logotipo, dinâmica de grade, cenários, produções e posicionamento da emissora. Ouvimos nossos telespectadores, que, em breve, serão brindados com novo transmissor e antena, que garantirão a excelência de novo sinal chegando aos telespectadores e ouvintes da sociedade brasileira. $\mathrm{Na}$ Rádio MEC, reestruturamos as programações da FM e da AM, estamos recuperando o precioso acervo, além de modernizarmos parte da área tecnológica e reformarmos as instalações prediais. (SOUZA, 2014, apud ACERP, 2006, P.7).

Os avanços eram muitos e o envolvimento dos profissionais era visível pelo entusiasmo. A preparação do Plano Estratégico 2003-2006, quando a gestão de Carmona dava os primeiros passos, reuniu a equipe de profissionais para debater as diretrizes da instituição. Assisti a uma apresentação sobre esse trabalho ainda quando presidente da FCBTV TVE/RS. O Seminário de Planejamento foi realizado logo depois do Seminário Desafio da TV Pública, momento em que foi apresentado para todos os participantes a pesquisa que estava em andamento na TVE Brasil para responder "Quem é o Telespectador de TV Pública". Nádia Rebouças, da Rebouças \& Associados, responsável pelo desenvolvimento da pesquisa adiantou algumas questões, que serviam para reflexão de todos os dirigentes: "Quem pode ser o consumidor da TV pública? Nós não temos grandes audiências, e gostaríamos de crescer essa audiência, para ganhar credibilidade e conseguir investimentos e recursos. Então, quem pode ser esse espectador?". Os resultados, juntamente com o Planejamento Estratégico, seriam importantes como etapas a serem vencidas como se constata no relatório de 2006.

Também a Radiobrás era outra ao final de 2006 e início de 2007, resultado das discussões sobre comunicação pública em contraposição à governamental, que tinham alcançado um público eclético e de todo o País. Em Brasília, 19 horas (2008), Eugenio Bucci relata as dificuldades encontradas ao assumir a Radiobrás, e a luta para mudar as perspectivas de uma empresa de comunicação governamental para estatal. Entre as revelações, Bucci narra o primeiro encontro em abril de 2007 com o ministro Franklin Martins, que chegava quando as discussões e estudos preparativos do Fórum Nacional das TV'S Públicas já estavam em andamento e o evento próximo a se realizar. O então presidente da Radiobrás assim descreve a proposta que fez ao ministro:

Expus a situação da empresa, passei ao novo ministro alguns documentos, entre eles, o Manual de Jornalismo da Radiobrás e fiz uma proposta para o futuro: dissolver a Radiobrás e a TVE do Rio de Janeiro numa só 
organização, regida pelos princípios públicos de independência financeira, administrativa e editorial. ${ }^{41}$

Para o ministro Franklin Martins que chegava da iniciativa privada e aterrissava no governo em um momento de intensas discussões sobre o tema da comunicação pública, era um presente receber uma sugestão vinda de um dirigente de uma das empresas vinculadas à sua área, acompanhado de estudos e relatórios de realizações no período de quatro anos. Alguém que vinha tratando e estudando o tema há algum tempo e que, além de ser presidente da Radiobrás tinha sido conselheiro da ACERP, conhecia essa empresa, tanto do ponto de vista financeiro quanto de programação.

Havia, entretanto, fatos da rotina das duas instituições que eram muito distintos e que os relatos nos conselhos não abarcavam. O dia-a-dia era complexo tanto para uma como para outra e com características muito particulares. Uma operava como articuladora de conteúdo entre os vários órgãos estatais e do próprio Governo (lidava com a comunicação do governo e seus ministérios e órgãos administrativos). A outra tinha como foco a comunicação com a sociedade, com a pluralidade que uma televisão aberta exige - produzia conteúdo voltado à cidadania e à cultura, conforme seus compromissos.

As conversas para criação da primeira empresa pública nacional de comunicação aconteciam muitas vezes sem a presença dos presidentes da Radiobrás e ACERP, que estavam envolvidos diretamente na condução das instituições, trabalho que exigia dedicação intensa, como pude testemunhar diretamente no caso da ACERP. Enquanto as reuniões aconteciam no Palácio ou depois da chegada do ministro Franklin, na SECOM, fora dali outros agentes esmiuçavam estudos teóricos e experiências de outros países no campo da comunicação pública.

Muitos desses estudos, impulsionados pelo Ministério da Cultura, foram arrolados no documento prévio do I Fórum Nacional de TVs Públicas, reunidos no Caderno de Debates editado pelo MINC, em 2006, como o Diagnóstico do Campo Público de Televisão. Esse caderno reuniu textos do ministro da Cultura, Gilberto Gil; do Secretário do Audiovisual, Orlando Senna; de Eugênio Bucci, presidente da Radiobrás; da presidente da TVE Brasil (ACERP), Beth Carmona; de Mario Borgneth ${ }^{42}$, assessor do Ministério da Cultura/Secretaria

\footnotetext{
${ }^{41} \mathrm{~A}$ intenção poderia ser boa, mas não é o que vai se provar com o tempo, com os desdobramentos posteriores ao impeachment da presidente Dilma Roussef. As trocas de assento foram mais uma vez acionadas.

${ }^{42}$ Mario Borgneth atuava na TV Cultura, Fundação Padre Anchieta, como gerente de Documentários quando o DOC TV foi lançado em 2003, como já informado.
} 
do Audiovisual. Em seu texto, Borgneth destacou a mobilização de agentes do governo e da sociedade civil para a realização do Fórum, como transcrevo a seguir:

A preparação do I Fórum Nacional de TVs Públicas, em curso desde setembro último (2006), tem sido capaz de mobilizar importantes setores do governo federal e da sociedade civil, reunindo, de forma pioneira, o mais completo conjunto de informações, visões e propostas a respeito do desenvolvimento do campo público de televisão no Brasil.

Segundo Borgneth, com o apoio do Gabinete da Presidência da República e da Casa Civil, do engajamento da Radiobrás e TVE/Rede Brasil, sob a coordenação da Secretaria do Audiovisual do Ministério da Cultura, a proposta de articulação institucional rumo ao Fórum recebeu adesão imediata da Associação Brasileira das Emissoras Públicas e Culturais (ABEPEC), que reunia 19 geradoras de televisão abertas com finalidade educativa, pública e cultural); da Associação Brasileira de Televisão Universitária (ABTU); da Associação Brasileira de Televisões e Rádios Legislativas (ASTRAL); da Associação Brasileira de Canais Comunitários (ABCCOM). Essas associações descreveram suas áreas o que resultou num conjunto de documentos capaz de traçar um diagnóstico do campo público de televisão, fato inédito na história do País. As condições estavam armadas para a realização do Fórum que debateria, em síntese, a criação de uma empresa de comunicação pública.

Eugênio Bucci deixou a presidência da Radiobrás em 20 de abril de 2007, dias depois da posse do Ministro-chefe da Secretaria de Comunicação Social da Presidência da República, Franklin Martins, em 29/03/2007³, quando todos os preparativos para o Fórum Nacional das TV'S Públicas estavam concluídos. Os grupos temáticos, que contavam com a participação de representantes de emissoras de TV e radiodifusoras públicas e educativas, TVs universitárias, TVs comunitárias, TVs legislativas, expositores internacionais, instituições participantes dos grupos de trabalho, autoridades do Governo Federal, secretários estaduais de Cultura, organizações da sociedade civil e parlamentares tinham concluído a etapa de mapeamento e diagnóstico do segmento do campo público de televisão e elaborado pautas que seriam levadas para o encontro. Esse material foi reunido no Caderno de Debates Volume 2, apresentado no dia 9 de abril, em cerimônia no Palácio Gustavo Capanema, Sede

\footnotetext{
${ }^{43}$ A nova secretaria assumiu as competências da Secretaria Geral da Presidência da República, e passou a ter status de Ministério (Medida Provisória 360, de 28/03/2007, convertida em Lei $n^{\circ} 11.497$, de 2007). SOUZA, 2014, p. 117.
} 
do Ministério da Cultura (Minc) no Rio de Janeiro. (CF. Observatório do Direito à Comunicação, 2007) $)^{44}$.

Orlando Senna, secretário do Audiovisual, e Mario Borgneth, assessor especial do Ministério da Cultura (Minc), descreveram na abertura do Caderno de Debates 2, o processo de trabalho que mobilizou 250 geradores e programadores de TV organizados nesta entidade que, em conjunto com o Ministério da Cultura, elaboraram o mais completo diagnóstico sobre a situação das TVs públicas brasileiras (publicado no documento Caderno de Debates 1 Diagnóstico do Campo público de Televisão). De acordo com o texto, para a segunda etapa, de forma a ampliar o arco institucional, foram criados Grupos Temáticos de Trabalho, com representantes de oito ministérios, das agências reguladoras do cinema e das comunicações, universidades, organizações da sociedade civil e entidades representativas do campo público. Ou seja, tudo pensado e planejado para ser o mais diverso e interdisciplinar possível. O anseio do Ministério da Cultura e de entidades da sociedade civil era ter o Minc à frente na coordenação da televisão pública. Mas a batalha foi vencida pelo grupo liderado pelo ministro Franklin Martins, recém-chegado ao "bonde TV pública”.

Entre 8 e 11 de maio de 2007 se realizou o Fórum Nacional das TV'S Públicas com intensos debates. Acompanhamos as transmissões das plenários do Fórum no Rio de Janeiro, tanto nas rádios MEC como na TVE Brasil. Depois do Fórum imediatamente começou o processo de junção da Radiobrás com ACERP- TVE Brasil e Rádios MEC, antes da criação da nova empresa. No dia 22 de maio, se realizou a primeira reunião para tratar da fusão das duas instituições, na sede da Radiobrás, em Brasília, por determinação da SECOM. No primeiro momento, uma reunião geral juntou as equipes que representavam a televisão e o rádio. O grupo que partiu do Rio, chefiado pela presidente da ACERP, Beth Carmona, foi munido de relatórios, grades de programação, um diagnóstico completo do funcionamento das emissoras e quadro de funcionários, entre outras análises. Depois de uma reunião geral, foram formados dois grupos de trabalho - GT Televisão e GT de Rádio.

Nesse primeiro encontro, que participei como gerente executiva da MEC e sobre o qual redigi uma ata distribuída a todos os integrantes do GT Rádio, também fizeram parte, pela SECOM, Eduardo Castro; pela Rádio MEC, o diretor Orlando Guilhon. Da Radiobrás, estavam Taís Ladeira de Medeiros, chefe do Departamento de Rádio; Patrícia Lemos Duarte, Coordenadora de Atividades; e Helenise Brant, representante do Departamento de Jornalismo.

\footnotetext{
${ }^{44}$ Disponível em http://www.intervozes.org.br/direitoacomunicacao/?p=18137, publicado em 9 abr. 2007. Acesso em 4 ago. 2016.
} 
Na pauta, o diagnóstico das duas instituições, do ponto de vista de conteúdo e programação, e a estrutura de produção. As diferenças eram imensas. Descrevi com detalhes o relato feito por Helenise Brant sobre as emissoras que integravam a Radiobrás: Rádio Nacional (AM) do Rio de Janeiro, Rádio Nacional FM e Rádio Nacional AM, em Brasília, Rádio Nacional da Amazônia (OC), Rádio Meso-regional do Alto Solimões, em Tabatinga (AM). Essas rádios tinham características distintas que tornavam difíceis as discussões para integração sem interferir nas estruturas das emissoras que, no caso da MEC AM, no Rio, já somava algumas décadas. A ACERP reunia no Rio duas emissoras - MEC AM e MEC FM, e uma Rádio MEC AM, em Brasília, que reproduzia a programação da MEC FM, do Rio, dedicada majoritariamente à música clássica, sendo a única emissora na capital federal a transmitir esse gênero.

As reuniões se sucederam, sempre alternando o local dos encontros entre Rio e Brasília. Na semana seguinte, 28 de maio de 2007, aconteceu o segundo encontro, desta vez no Rio de Janeiro, o que facilitava a participação de outros profissionais da equipe MEC. Participei como gerente executiva da rádio com Liara Avelar, líder do Núcleo de Programação e Produção da AM; Marcelo Brissac, líder do Núcleo de Programação e Produção da FM, e Orlando Guilhon, diretor. De Brasília vieram os mesmos participantes da primeira, Eduardo Castro, Taís Ladeira e Helenise Brant, mais a equipe do Rio de Janeiro, Edna Dantas, chefe do escritório da Radiobrás, no Rio, Aloísio Milani, editor-executivo da Agência Brasil.

Seguiram as discussões sobre cada tronco ou eixo do novo sistema, sugerido pelo representante da SECOM, além da grade de programação das emissoras com vistas a pensar nos eixos nacionais, e a metodologia para otimizar o trabalho. As reuniões continuaram deslocando as equipes entre Brasília e Rio durante aquele ano. Em 3 de agosto de 2007, houve outra reunião, no Rio, reunindo o mesmo grupo, já com mais definições dos tais eixos. De todas as resoluções e proposições, das idas e vindas, muito pouco foi implementado. A Empresa Brasil de Comunicação foi criada em 2007 com novos protagonistas, e muito dos diagnósticos e discussões foram abandonados.

Segui nesse texto um percurso empírico, narrar o que me toca, o que me tocou e o que busco entender. Para isso, me valho do percurso teórico, ajudado pela bibliografia e os saberes de outras experiências. "Nessa intranquilidade, nada como realimentar o espírito no oxigênio da arte", como ensina Cremilda Medina (MEDINA, 2003, p.61). Nos momentos de angústia pelas mudanças nos caminhos do sujeito de pesquisa me refugio na arte. Tenho consciência de que "os desafios são mais grandiosos do que as racionalizações. Sempre 
alguma coisa escapa à cartografia apreendida, gramaticalizada" (Ibid, p.79). Esse texto se guia pela observação-experiência (MEDINA, 2016). E, como disse Jorge Larrosa (que já citei de passagem na Apresentacão) em uma conferência na Unicamp e que foi publicada na Revista da Educação ${ }^{45}$.

Se a experiência não é o que acontece, mas o que nos acontece, duas pessoas ainda que enfrentem o mesmo acontecimento, não fazem a mesma experiência. $\mathrm{O}$ acontecimento é comum, mas a experiência é para cada qual a sua, singular e de alguma maneira irrepetível. O saber da experiência é um saber que não pode separar-se do indivíduo concreto em quem encarna. Não está como o conhecimento científico, fora de nós, mas somente tem sentido no modo como configura uma personalidade, um caráter, uma sensibilidade ou, em definitivo, uma força humana singular de estar no mundo que é por sua vez uma ética (um modo de conduzir-se) e uma estética (um estilo). Por isso também o saber da experiência não pode beneficiar-se de qualquer alforria, quer dizer, ninguém pode aprender da experiência de outro a menos que essa experiência seja de algum modo revivida e tornada própria.

Os capítulos que se sucedem abordam os dois casos em estudo, com suas histórias, percursos, gestão e descontinuidades. Também trataremos em linhas gerais da noção de TV pública - teórica e acadêmica, e a percepção de alguns profissionais e especialistas colombianos. Não se trata de um ortodoxo estudo comparativo, por todas as diferenças e singularidades entre esses dois países. Assim, sempre que possível traço paralelos, respeitando as respectivas identidades.

\footnotetext{
${ }^{45}$ LARROSA Bondía, Jorge. Notas sobre a experiência e o saber da experiência. Revista Brasileira de Educação. Universidade Estadual de Campinas, Instituto de Linguistica. Campinas, 2002. ScIELO. N ${ }^{\circ} 19$ (Jan/Fev/Mar/Abr 2002 ) Também disponível em: <http://www.scielo.br/pdf/rbedu/n19/n19a02.pdf>.
} 


\section{Um conceito em crise: Governamental, Estatal ou Pública?}

É indispensável para reformular a teoria um pensamento aberto à desordem social, a qual não comporta um relato único e abrangente; é preciso ter em mente a exigência antropológica de escutar os mais diversos atores, deter-se no qualitativo, na densidade intranquilizante dos fatos. (CANCLINI, 2012, 245)

Diante dos fatos ocorridos em 2016, com a troca de governo pelo impeachment da presidente Dima Roussef, uma questão se impõe para reflexão neste texto, inspirada pela epígrafe: a televisão pública, como descrevem alguns conceitos citados adiante continua um ideal desejado por profissionais, estudiosos, especialistas, organizações e movimentos sociais? É possível afirmar hoje, 2017, que o Brasil não tem e tampouco chegou a ter uma televisão essencialmente pública mesmo com a chegada da $T V$ Brasil-EBC? Eis o que pretendo refletir aqui.

Resgato para iniciar uma frase ouvida de um dos membros da banca durante o meu exame de qualificação e que ficou guardada. Era uma constatação que já me acompanhava de outros tempos de pesquisa e também do exercício profissional. Pouco mais de um mês depois da qualificação, os fatos viriam despertar minha memória. "Uma gestão alinhada ao poder mata a TV pública", foi a frase dita pelo Prof. Dr. Eugenio Bucci. Era o que se constatava por ocasião do impeachment da presidente Dilma Roussef em maio de 2016, depois de tantas descontinuidades que a história testemunhou, muito antes da criação, em 2007, da Empresa Brasil de Comunicação (EBC), mantenedora da TV Brasil.

As mudanças de gestão das emissoras de comunicação pública nas trocas de governo, mesmo que interinos e temporários, foi a premissa dessas instituições. Desde meados do século passado essas emissoras geridas com recursos estatais são tratadas como objetos de estimação temporários, jogados de um lado para outro pelos governantes de plantão. Mudam de "dono" sem prestar contas à sociedade, ignorando seus conselhos - curador, de administração ou deliberativo. Esses têm sido, ao longo dos tempos, figuras decorativas para respaldar as deliberações dos ocupantes do governo e, raramente, ouvidos pelos mandantes.

Esse movimento aconteceu mais uma vez. A aprovação para tramitação do processo de impeachment da presidente Dilma Roussef pelo Senado Federal, que determinou num primeiro momento seu afastamento por 180 dias e a posse do vice-presidente Michel Temer 
como presidente interino, não impediu a repetição do gesto dos governantes que assumem o comando das instituições de Estado. Ainda se confunde público, estatal, com o governamental. Esquece-se de que este "público" representa a sociedade, os contribuintes, que pagam pelos serviços para uma comunicação pública, isenta, independente e cidad $\tilde{a}^{46}$. Confunde-se governo, a gerência, com a instituição neutra que faz parte da estrutura de Estado. Por isso, a questão: por que a $E B C$ criada neste século 21, depois de um longo período de discussões que se desdobraram a partir dos anos 1990 e culminaram com o I Fórum Nacional das TV's Pública em 2007, mantém as características de uma emissora governamental?

Os fatos em 2016 endossam esse questionamento. Os acontecimentos políticos atingiram a EBC cinco dias depois da votação do processo de impeachment da presidente no Senado Federal. No dia 17 de maio, o presidente interino Michel Temer exonerou o diretorpresidente da EBC, Ricardo Melo, e nomeou para ocupar o cargo o jornalista Laerte Rímoli. Melo fora nomeado pela presidente Dilma Roussef, dias antes de o Senado afastá-la temporariamente do cargo. No mesmo dia de seu afastamento, Ricardo Melo entrou com mandado de segurança no Supremo Tribunal Federal (STF) "para pedir a suspensão da medida tomada pelo presidente em exercício Michel Temer" (OESP, 2016, A5). Segundo o jornal $O$ Estado de S. Paulo, a defesa de Melo afirmava que sua exoneração, publicada no Diário Oficial da União do dia 17 de maio, fora um "ato arbitrário, abusivo e ilegal". O advogado argumentou que a EBC é uma empresa pública, não estatal, e que por isso o mandato do presidente da instituição é fixado em quatro anos, independente de quem assuma o governo. (OESP, 2016, A5).

A troca não durou muito, mas já bastou para o presidente nomeado por Michel Temer demitir ocupantes de cargos de confiança, como assessores, gerentes e coordenadores. Ato contínuo, nomeou substitutos para a maioria dos cargos. No dia 25 de junho, conforme nota da Agência Brasil, foram nomeados os novos diretores de Administração, Finanças e Pessoas, Jornalismo e Diretoria de Produção ${ }^{47}$. Logo chegaria a revanche. No dia $1^{\mathrm{o}}$ de junho, o ministro Dias Toffoli, do STF, deu seu aval para que o jornalista Ricardo Melo reassumisse

\footnotetext{
${ }^{46}$ Já no final do século passado as televisões públicas do mundo se reuniam anualmente em torno do International Public Televison Screening (INPUT), para analisar as estratégias dos governos, sociedades, produtores e realizadores utilizavam para reivindicar a televisão pública como o lugar social de todos, como uma alternativa audiovisual de encontro da sociedade, de fomento dos direitos dos cidadãos, e de reconhecimento da pluralidade social que nos habita. (Cf. RINCON, 2002, 28)

47 Disponível em: <http://agenciabrasil.ebc.com.br/geral/noticia/2016-05/consad-nomeia-novos-diretores-daebc>. Acesso em 03 jul. 2016.
} 
suas funções de diretor-presidente da EBC, estatal criada em 2007 para gestão das empresas de TV e rádio do governo federal, informou o jornal Folha de S. Paulo. (FSP, 03/06/2016, A6).

A trégua durou até a votação final do processo de impeachment. Logo depois da posse de Michel Temer, dia 2 de setembro, mais um sobressalto. Decreto publicado no Diário Oficial da União (DOU) e assinado pelo Deputado Rodrigo Maia (DEM-RJ), que exercia a presidência da República enquanto Michel Temer estava na China ${ }^{48}$, altera o Estatuto Social da EBC. Esta passa a ser vinculada à Casa Civil (Cf CIEGLINSKI, Amanda ${ }^{49}$ ). Repete-se o que foi no governo Sarney, quando a Funtevê esteve ligada ao Gabinete Civil da Presidência. E mais: Ricardo Melo volta a ser exonerado. O atropelo sofre recuo. No mesmo dia, em edição extra do DOU, novo decreto torna sem efeito a exoneração. As idas e vindas não cessaram. No dia 8 de setembro, o ministro Dias Toffoli, do STF, revoga a liminar que mantinha Ricardo Melo na presidência da EBC. A decisão foi tomada após a publicação do decreto que alterou o Estatuto Social da Empresa (Cf. Agência Brasil). ${ }^{50}$

\subsection{Mandos e desmandos}

Não foi um fato novo nas trocas de governo. O que difere, nesse caso, é que nos oito anos da EBC as trocas de gestores foram de acordo com a lei que a criou, ao final dos mandatos de quatro anos da diretoria, com uma exceção. O terceiro diretor-presidente nomeado por Dilma Roussef, Américo Martins, pediu seu afastamento sete meses depois de assumir $^{51}$. Entrei em contato com Américo Martins quando ele já estava de retorno à BBC_em Londres (onde já tinha trabalhado em anos anteriores), e informei o sobre minha pesquisa de

\footnotetext{
48 Para a reunião de cúpula do G20, grupo das maiores economias do mundo. (Cf. $<$ http://www.bbc.com/portuguese/brasil-37257767>. Acesso em 5 set. 2016.

49 Agência Brasil. Em: <http://agenciabrasil.ebc.com.br/geral/noticia/2016-09/medida-provisoria-e-decretosmodificam-estrutura-e-trocam-comando-da-ebc>. Acesso 2 set. 2016.

$50<$ http://agenciabrasil.ebc.com.br/geral/noticia/2016-09/toffoli-cassa-liminar-e-ricardo-melo-deixa-presidenciada-ebc-rimoli-reassume>. Acesso em 20 set. 2016.

${ }^{51}$ Américo Martins pediu demissão do cargo de presidente da Empresa Brasil de Comunicação (EBC) em 02/02/2016. A nomeação de Ricardo Melo aconteceu no dia 02/05/2016 (três meses depois). Ele ocupava o cargo de Diretor de Jornalismo desde 27/08/2015. Cf. Valor Econômico disponível em $<$ http:/www.valor.com.br/politica/4499760/americo-martins-deixa-presidencia-da-empresa-brasileira-decomunicacao> e Carta Capital <http://www.cartacapital.com.br/sociedade/o-que-esta-por-tras-da-saida-dopresidente-da-ebc $>$ e Agência Brasil http://agenciabrasil.ebc.com.br/geral/noticia/2016-05/ricardo-melo-e-onovo-presidente-da-ebc. Acessos em 26 jan. 2017.
} 
Doutorado. Perguntei se ele estaria disposto a falar sobre sua saída da EBC. Em mensagem de 03 de janeiro de 2017, respondeu:

Eu topo conversar com você, sim, com prazer. Mas não vou falar sobre minha saída e nem sobre o momento particular da EBC. A empresa faz parte do meu passado e eu não acompanho mais o que acontece lá há muito tempo. Então, nem tenho como comentar a respeito. Mas posso, claro e com prazer, falar sobre comunicação pública em geral e sobre a $\mathrm{BBC}$ e seu modelo, em particular. Não sei se isso te ajuda ou não, mas é a área onde eu posso de fato contribuir.

Martins substituiu Nelson Breve, que se manteve no cargo por quatro anos, retornando depois ao antigo posto que ocupava na Secretaria de Comunicação da Presidência da República (SECOM), processo chamado de porta giratória ${ }^{52}$ por organizações da sociedade civil e funcionários.

A EBC, que surgiu como uma nova proposta que encerraria o ciclo das televisões "governamentais" até então mantidas pelo Governo Federal e pelos Estados, vem repetindo o modelo das emissoras surgidas na ditadura, ou seja, opera sob estreita intervenção dos governos. O cataclismo que se abateu na empresa a partir do primeiro semestre de 2016 cresceu de intensidade dia a dia ${ }^{53}$.

A repercussão do afastamento do presidente da EBC, Ricardo Melo, a nomeação de Laerte Rimoli, e o retorno do primeiro, dias depois, ganharam espaços nos jornais brasileiros. Colunistas, como Eugenio Bucci $^{54}$ (Temer errou com a EBC) e a ex-presidente da EBC

\footnotetext{
${ }^{52}$ Porta giratória é como classificam em Brasilia as idas e vindas de donos de cargo entre instituições, como a EBC, e outros cargos na Presidência da República.

${ }^{53}$ Resgato alguns fatos que ocorreram naquele mês de maio, com desdobramentos depois do impeachment, que desmoronam a ideia da EBC como empresa pública de comunicação independente e autônoma. O retorno do diretor-presidente ao seu posto com a readmissão de alguns afastados por Laerte Rímoli não cessou a gana do Governo Federal naqueles dias. Me refiro à decisão de Ricardo Melo de chamar um dos apresentadores demitidos por Laerte Rimoli, Luís Nassif, para entrevistar Dilma Roussef, naquele afastamento temporário da presidência da República. A entrevista foi ao ar na quinta-feira, 9 de junho, depois de ter sido suspensa a transmissão, como estava anunciada, no dia 6 de junho. Assim o jornal $O$ Globo se referiu em seu site: Ricardo Melo, o presidente da EBC, suspendeu a exibição da entrevista de Dilma Rousseff com Luís Nassif, que seria agora à noite, após uma reunião com o sindicato de profissionais da empresa pública. Os servidores afirmaram que uma entrevista conduzida por Nassif, cujo contrato foi rompido, seria irregular. Melo disse que pretende ainda que a EBC faça entrevistas com Michel Temer, Renan Calheiros e Ricardo Lewandowski. In: AMADO, Guilherme. EBC suspende exibição de entrevista de Dilma com Luís Nassif. O Globo. Disponível em: $<$ http://blogs.oglobo.globo.com/lauro-jardim/post/ebc-suspende-exibicao-de-entrevista-de-dilma.html $>$. Acesso em 7 jun. 2016.

${ }^{54}$ Temer errou com a EBC. OESP, 26/05/2016. < http://opiniao.estadao.com.br/noticias/geral,temer-errou-com-aebc,10000053509>. Acesso em 26 mai. 2016.
} 
Teresa Cruvinel $^{55}$ (Futuro da EBC em risco), escreveram sobre o gesto de Temer com análises sobre o papel da emissora pública e os compromissos desta com a sociedade. As notas sobre as intenções de Temer em relação à EBC continuaram ocupando a atenção da mídia impressa e digital. Entre maio e junho a empresa frequentou com assiduidade espaços de reportagem e colunas dos principais jornais brasileiros. Já antes do impeachment, no dia 4 de maio, $O$ Estado de $S$. Paulo dedicou mais de meia página à empresa, com o seguinte título e subtítulo: Troca na EBC chega em fase turbulenta - Ricardo Melo é o novo diretorpresidente de empresa pública hoje questionada por servidores. A reportagem informava que a presidente Dilma Roussef havia nomeado o jornalista Ricardo Melo como diretor-presidente para um mandato de quatro anos. E ia além, já antecipando o que aconteceria dias depois:

A escolha do novo chefe do órgão ocorre no momento em que a equipe do vice-presidente Michel Temer avalia mudanças bruscas na política de comunicação, com o enxugamento dos custos da empresa, diminuição do orçamento de publicidade das estatais e o fim da contratação de veículos limitados à divulgação de textos opinativos, caso de Dilma seja afastada (OESP, 04/05/2016, A11).

O diagnóstico da empresa feito pelo jornal colocava mais argumentos aos desdobramentos que viriam após votação pelo Senado Federal da tramitação do processo de impeachment. "Atualmente, a empresa de comunicação do governo possui 2.563 funcionários nas redações da Agência Brasil, TV Brasil, Portal EBC, Canal NBR e oito rádios, incluindo a Nacional e a MEC, sendo 178 deles em cargos de confiança, livre provimento sem vínculo com a administração pública e um orçamento de R $\$$ 538,5 milhões”. Também relatava os constantes movimentos de greve dos empregados da EBC, que reclamam dos privilégios dados pelo Planalto a um grupo de 51 pessoas, "entre servidores de carreira e comissionados, com salários que chegam a R 32 mil, fora as gratificações”. (Ibid)

A admissibilidade do processo de impeachment foi votada no dia 12 de maio e cinco dias depois começaram a borbulhar notas, matérias e colunas em sites e jornais sobre a EBC. Depois de noticiar o afastamento do diretor-presidente no dia 17/05, e o seu retorno quase imediato, a empresa não teve sossego. As matérias e artigos se multiplicaram com alguns títulos que destaco aqui: EBC cancela contrato polêmico com jornalista Sidney Rezende (OG, 21/05/2016); TV Brasil programa entrevista com Dilma (OG, 05/06/2016,10); A TV chapa-

\footnotetext{
${ }^{55}$ CRUVINEL, Tereza. Futuro da EBC em risco. FSP, 02/06/2016.
} 
branca (editorial OESP, 07/06/2016, 2); EBC poderá ser extinta (chamada capa OG, 11/06/2016, 1 e 2); Um mês depois - Foco de resistência, EBC é alvo do governo Temer, (OG, 12/06/2016, 5) foi a chamada principal. Dividiam a página mais duas matérias com o ministro chefe da Casa Civil, Eliseu Padilha (Padilha admite que Planalto pode extinguir TV Brasil), e a outra com a presidente do Conselho Curador da EBC, Rita Freire ('Em 10 dias, se tocou o terror ali dentro' diz conselheira).

Em 16/06/2016 (FSP, A3), a presidente do Conselho Curador, Rita Freire, ${ }^{56}$ escreveu em defesa da instituição o artigo A disputa pela EBC. "A Empresa Brasil de Comunicação vem sendo alvo de ameaças de desmonte feitas pela equipe do presidente interino Michel Temer", afirmou na abertura do texto. Freire fez críticas à exoneração do diretor-presidente, Ricardo Melo, "enquanto exercia um mandato protegido por lei” e à indicação de Laerte Rímoli para o comando da $E B C$. Lembrou que dez dias depois Ricardo Melo retornou ao cargo por "força de liminar do ministro Dias Toffoli". A presidente do Conselho Curador destacou que os recursos da $E B C$ mantêm um conjunto de emissoras de rádio além da TV Brasil, "esta que os detratores querem medir pela audiência, mas cujo conteúdo desconhecem" (FSP, 16/06/2016, A3). Freire descreveu diferenciais da programação e encerrou defendendo que a EBC precisa, urgentemente, desvincular-se da Presidência da República e separar sua missão pública da prestação de serviços ao canal de $T V N B R$. Este, sim, é do governo federal. O restante é nosso", encerrou, assim, seu artigo. A afirmação de Rita Freire estava em acordo com as reivindicações apresentadas no Seminário Modelo Institucional da EBC: balanço e perspectivas ${ }^{57}$, realizado pelo Conselho Curador em agosto de $2015^{58}$, na gestão da presidente Dilma Roussef, conforme o documento final:

A intenção do Seminário foi fazer um balanço dos oitos anos da EBC e discutir com a sociedade o modelo institucional da Empresa no que diz respeito às formas de garantia do princípio de autonomia do Governo Federal e da participação da sociedade civil no controle e na aplicação dos princípios do sistema público de radiodifusão".

\footnotetext{
${ }^{56}$ Jornalista pela Faculdade de Jornalismo da Fundação Casper Líbero, pós-graduada em Política Internacional pela Fundação Escola de Sociologia e Política de São Paulo, editora, gestora e dirigente da Ciranda Internacional de Comunicação Compartilhada (Compas).

${ }^{57}$ SEMINÁRIO Modelo Institucional da EBC. Disponível em <https:/www.doity.com.br/seminario-modeloinstitucional-da-ebc>.

${ }^{58}$ Seminário Modelo Institucional da EBC: balanço e perspectiva, que acompanhei em Brasília, nos dias 11 e 12 de agosto de 2015.
} 
Pelas manifestações de organizações da sociedade civil e de funcionários da empresa, percebeu-se naquele encontro que a autonomia não existia, a junção $N B R$ (oriunda da Radiobrás) com TV Brasil era danosa para a imagem desta última como uma televisão pública independente. Para os participantes, complicava mais ainda a vinculação à SECOM, outro tema que mereceu debates nas reuniões de grupos e na sessão final. Ainda em novembro daquele ano (2015), em um encontro com o professor Omar Rincón em Bogotá (em 17/11/2015), ele lembrou que o Brasil teve o modelo ideal quando eram duas empresas distintas e gestões separadas - a Radiobrás e a TVE Brasil, gerida pela Associação de Comunicação Educativa Roquette-Pinto (ACERP).

A presença da $E B C$ na mídia continuou. No dia 25 de junho de 2016, a Folha de $S$. Paulo dedicou seu editorial à empresa. Canal chapa-branca foi o título do texto que assim iniciou: "Era de prever e foi previsto neste espaço: a EBC (Empresa Brasil de Comunicação) nasceu e cresceu como aparelho de propaganda a serviço do governo de turno". Depois de breve descrição sobre a criação da $E B C$ com algumas críticas, o editorial faz seu prognóstico: “A EBC nunca será de fato autônoma, com o PT ou outro partido". (FSP, 25/06/2016, A2)

O tema da desvinculação do governo, como já referido, mereceu amplo debate no seminário do Conselho Curador. Com a presença de entidades da sociedade civil, pesquisadores, autoridades e funcionários, o seminário iniciou os trabalhos com a leitura das contribuições enviadas antecipadamente pelos participantes. $\mathrm{O}$ primeiro texto foi o do Conselho Curador, lido pela então vice-presidente do colegiado (assumiu a presidência no dia 09/12/2015), Rita Freire. Transcrevo algumas das suas colocações:

Um tema comum a todas as contribuições recebidas está relacionado à sua autonomia. Queremos que não seja só a vinculação e financiamento, mas aquela autonomia ampla que pode incidir na programação - poder dialogar com a sociedade. Essa autonomia depende de um empoderamento das equipes da EBC. Essa falta impacta a qualidade. Precisamos que esse seminário nos ajude a construir empoderamento e pertencimento.

De acordo com o documento final do seminário ${ }^{59}$, dividido em eixos ${ }^{60}$, as discussões se centraram nas questões da autonomia e da vinculação à SECOM como pontos nevrálgicos. Também mereceu destaque a separação da EBC Serviços da TV Brasil, para evitar que a

\footnotetext{
59 Disponível em: <http://www.ebc.com.br/institucional/conselho-curador/noticias/2015/10/publicadodocumento-final-do-seminario-modelo-institucional-da-ebc>. Acesso em jun. 2016.

${ }^{60}$ Os eixos foram: Autonomia e Vinculação; Financiamento e Sustentabilidade; e Gestão de Conteúdo e Participação Social.
} 
sociedade veja a "emissora pública" como "emissora governamental". Exatamente como era antes da EBC segundo lembrou Omar Rincón, já referido. O texto lido pela jornalista Priscila Kerche, representante da comissão de empregados da EBC, também frisou:

[...] apesar de a autonomia em relação ao Governo Federal para definir produção, programação e distribuição de conteúdo, estar prevista em sua lei de criação, nós temos visto nesses anos de existência da EBC, uma relação árdua entre a empresa e o governo federal, em busca dessa autonomia. (Grifo nosso)

Para a então representante dos funcionários, já naquele momento era fundamental o estabelecimento de um mecanismo de indicação dos dirigentes da empresa que não fosse vinculado ao governo, que privilegiasse o histórico de atuação na área da comunicação pública e o corpo próprio da empresa, e que garantisse que a sociedade fosse ouvida em sua indicação. "A falta de regras na nomeação de cargos de livre provimento e a nomeação pela presidência de cargos e de representantes nos espaços de participação social prejudica, e muito, o conteúdo que vai ao ar em nossos veículos”. Essa não era uma crítica distante, vinha de quem conhecia os meandros internos. Em relação às indicações políticas, Kerche afirmou que era de conhecimento público a alternância de cargos assumidos na SECOM e na $E B C$ por determinados profissionais. Era a já referida "porta giratória". É muito comum que o próprio governo enxergue a $E B C$ e a $E B C$ Serviços, $T V$ Brasil e $N B R$ como se fossem a mesma coisa".

Cito as repercussões dos jornais e parte das reflexões do seminário promovido pelo Conselho Curador para mostrar que o tema TV pública já mobilizava algumas instituições - a favor e contra a forma como vinham operando. Da perspectiva radicalmente dicotômica mídia privada e mídia pública - a primeira é considerada como "mídia hegemônica ciosa de sua exclusividade para ditar o que o brasileiro e a brasileira devem saber e pensar" 61 (LEAL FILHO, 2016, p.20). A favor de seu funcionamento, estavam os movimentos sociais, as entidades que compunham o Conselho Curador, o Fórum de Democratização da Comunicação, Sindicatos de Jornalistas e Radialistas, Federação Nacional de Jornalistas, entre outras organizações da sociedade civil: as mesmas que se mobilizaram em apoio à realização do Fórum Nacional de TV'S Públicas, em 2007, e que deu origem à criação da

\footnotetext{
${ }^{61}$ LEAL FILHO, Laurindo Lalo. Ameaçada, comunicação pública é vital para a democracia. In. LOPES, Ruy Sardinha. A Comunicação Pública em questão: crise na EBC. São Paulo: Socicom, 2016, p.20. Disponível em: $<$ http://www.socicom.org.br/55-conteudo/1023-socicom-debate-a-comunicacao-publica-em-questao-crise-naebc>. Acesso em 11 jan. 2017.
} 
Empresa Brasil de Comunicação. Segundo Eugênio Bucci (2016), a EBC jamais logrou construir uma base de apoio verdadeiramente ampla, "além do apoio mais ou menos partidário que obtinha de organizações e agrupamentos diversos que orbitavam o governo federal" ${ }^{\prime 62}$. Os retrocessos desencadeados a partir do impeachment tornam essa questão ainda mais relevante.

\subsection{O que entendemos como televisão pública}

Munida de diversos estudos e pesquisas me dei conta de que, quando os estudiosos tentam se referir à definição de TV pública, imperam os temas que envolvem independência, autonomia e financiamento (grifo nosso). Da reflexão e de todas as leituras recolhi algumas descrições sobre o significado de "televisão pública", de acordo com Eugênio Bucci, um "significado em disputa ${ }^{63 "}$.

Inicio a tarefa com uma definição que vi pela primeira vez quando presidia uma emissora pública ${ }^{64}$ e esta se configurou uma motivação para praticar o que Omar Rincón classificava em contraponto às emissoras comerciais, ou seja, a chamada pública ${ }^{65}$ : "a que privilegia o caráter público desse meio para superar a sua visão comercial e ganhar densidade como cidadã; a que nos relata como nos tornamos coletivo social” (RINCÓN, 2002, p.28). Na época, eu cursava a disciplina da Professora Cremilda Medina ${ }^{66}$ e tive a chance de levar a sua “dialogia social” para reflexão do grupo de profissionais da TVE-RS e Rádio FM Cultura (FCPRTVE). Essa aproximação da academia com uma empresa de comunicação pública se constituiu um trânsito profícuo para a pesquisa que agregava a "observação-experiência"

\footnotetext{
${ }^{62}$ Ibid, 2016, p. 41.

${ }^{63}$ Expressão usada pelo Prof. Dr. Eugênio Bucci durante exame de qualificação em 14/04/2016, quando sugeriu balizar um pouco o que é TV pública.
}

\footnotetext{
${ }^{64}$ Em 2003 fui convidada pelo Secretário de Comunicações do Estado do Rio Grande do Sul, para assumir a presidência da Fundação Cultural Piratini Rádio e Televisão, mantenedora da TVE-RS e Rádio FM Cultura. Recebi o apoio do presidente do Conselho Deliberativo da FCPRTV, Daniel Herz, com quem me comuniquei antes de aceitar.

65 Grifo do autor.

${ }^{66}$ Disciplina A Construção teórica do Jornalismo na Comunicação Social (2003)
} 
(MEDINA, 2016 ${ }^{67}$ ) à atividade como pesquisadora que experimenta a gestão que implementa e trabalha no campo de sua pesquisa.

Rincón foi o organizador do livro Televisão pública: do consumidor ao cidadão, resultado de um encontro realizado no Canadá em $2000^{68}$, que reuniu estudiosos e profissionais latino-americanos, entre eles Jesús Martin-Barbero, Germán Rey Beltrán, Diego Portales Fuentes, Valerio Fuenzalida Fernández, Nora Mazziotti, Guillermo Orozco Gómez e Teresa Montero Otondo. Essa publicação se juntava a outras de diferentes continentes, muitas no Brasil, olhando essa televisão agora com enfoque e abrangência maior levando em conta as tecnologias e os novos dispositivos que se juntam a ela numa verdadeira concorrência de telas.

Martín-Barbero defendeu naquele encontro, que era preciso começar a compreender a televisão na sua ação social e no seu potencial comunicativo, para conseguir fazer dela um dispositivo de nossos interesses sociais e culturais. "Compreender a televisão significa nos compreendermos como sociedade, nos olharmos como cidadãos, nos pensarmos como público" (MARTÍN-BARBERO, 2002, p. 25). A essa conceituação de Barbero, que remonta aos clássicos estudos da comunicação social, acrescentem-se as prerrogativas de independência e autonomia em relação a governos e mercado, e continuidade de projetos, o que não se assiste ainda na maioria das televisões públicas do Ocidente e tampouco no Brasil como demonstram os recentes acontecimentos.

Germán Rey (2002, p.106) contribui para esta reflexão ao lembrar que a importância da televisão na política deu às suas concessões papel de destaque, além de permitir "aos que a dominam influir no mundo político". Conforme este autor, as televisões públicas estariam (coloco no condicional porque o que assistimos hoje no Brasil é o inverso) fadadas a garantir o pluralismo político, a convergência de diferentes pontos de vista, o confronto de projetos sociais. "Associá-las a um partido ou governo é perverter sua vocação pública, como ocorreu durante anos em diferentes países da América Latina."

Rey escreveu este texto em 2002 quando os debates em defesa da televisão pública eram intensos na América Latina, em um cenário com os países saindo de governos

\footnotetext{
67 Alcançamos "quando circulamos com ansiedade para ensaiar o contexto plural, conflitivo não só das vozes como dos comportamentos (...) Nesse caso, não só valem a oratura do cotidiano como a experiência do contexto", que Cremilda chama de observação-experiência. MEDINA, Cremilda. Ato presencial. São Paulo: Casa da Serra, 2016.

${ }^{68}$ International Public Television screening confeences (INPUT), organização internacional de caráter voluntário que atuava em favor de uma televisão pública cidadã. (cf. OTONDO, 2002).
} 
totalitários e ditatoriais para gestões democráticas. Acreditava-se que se estava alcançando o "céu de brigadeiro" para essas emissoras. Não foi o que se assistiu na década seguinte, por exemplo, com as mudanças sofridas por essas emissoras no Brasil e na Argentina com trocas de governo - por eleições ou impeachment.

De Diego Portales Cifuentes (2002) destaco entre todas as questões relevantes que escreveu, com referenciais históricos da televisão pública no mundo, um tema que foi também debatido no Fórum Nacional das TV'S Públicas. Para ele, “o ponto de partida de qualquer estratégia de longo prazo para a construção da televisão pública é a geração de um estatuto jurídico que proporcione autonomia em relação ao governo em exercício”. Portales considerava, no início deste século, com as mudanças tecnológicas que estavam por vir, que "somente uma empresa autônoma do dono (o Estado, isto é, todos os cidadãos) pode tornar viável uma política estratégica que zele pela subsistência, pelo desenvolvimento e pela contribuição específica que a televisão pública deve dar à sociedade" (PORTALES, 2002, p.147).

"Na democracia (...) uma emissora pública existe para garantir um direito que tem a sociedade à informação, à cultura, à expressão de suas diferenças, à tematização de suas carências e potencialidades e à livre comunicação de ideias”, escreveram Eugenio Bucci, Marco Chiaretti e Ana Maria Fiorini, em Indicadores de qualidade nas emissoras públicas uma avaliação contemporânea, editado pela UNESCO, (Série Debates CI, nº 10, 2012). Os autores (BUCCI et all, 2012) fazem uma depuração da noção de emissora pública que aqui tento resgatar. Eles apontam três requisitos centrais que devem ser atendidos quando se trata de conceituar uma emissora pública: "em primeiro lugar, a natureza pública (do ponto de vista jurídico) da propriedade da emissora não pode ser propriedade direta de grupos privados, por definição". Consideram que ela pode ser financiada por fundos que sejam abastecidos por entes privados, mas não pode ser controlada por acionistas privados (grifo dos autores) - "ou não será pública”. Também consideram que é decisivo que o financiamento das operações da emissora seja assegurado por regras públicas, de acordo com a legislação vigente e garantido pelo Estado. No entanto, destacam, ela não pode estar subordinada ao governo, "mas deve ter sua existência assegurada pelas leis vigentes, inclusive quanto à sua forma de financiamento". Para esses autores, é o ordenamento público que regulamenta a sustentabilidade da emissora pública (Ibid, p.14). Consideram que o eixo central da ideia de emissora pública está na independência de sua gestão, em todos os seus aspectos (Grifo nosso). 
Se nos afastarmos das três palavras-chaves referidas por muitos estudiosos e avançarmos no que distingue a televisão pública, recuperamos Martín-Barbero (2002) ao dizer que: "É televisão pública aquela que interpela o público, incluído o consumidor enquanto cidadão". E diz mais: "A televisão pública acaba sendo, hoje, um decisivo lugar de inscrição de novas cidadanias, ${ }^{69}$ onde a emancipação social e cultural adquire uma face contemporânea". (MARTÍN-BARBERO, 2002, p. 57).

\subsection{E, no século 21, tudo como dantes...}

Passaram-se 15 anos do encontro do INPUT no Canadá quando, ao se traçarem parâmetros para a televisão, percebe-se que continua distante o ideal de comunicação pública independente e autônoma preconizado desde então. E não só em relação à $T V$ Brasil. Basta olharmos as televisões mantidas pelos Estados, em especial situação da $T V E-R S^{70}$, que integra a Fundação Cultural Piratini em vias de extinção ${ }^{71}$. Com a crise econômica neste 2017 acirra-se a questão: é papel do estado manter uma televisão pública em tempos de dificuldades econômicas que afetam serviços de saúde, educação entre outros de responsabilidade do poder público? Os requisitos apontados por Bucci, Chiaretti e Fiorini e Barbero seriam possíveis em televisões que, mais do que públicas, configuram-se como governamentais?

Ao olhar para o presente enquanto escrevo este texto em meio às intervenções do Governo na EBC, lembro do ex-presidente da Radiobrás Eugênio Bucci e sua afirmação de que a expressão comunicação pública "tem servido de curinga no jogo de cartas marcadas do clientelismo nacional: pode dar nome a qualquer mensagem do governo ou, principalmente, a

\footnotetext{
${ }^{69}$ Grifo do autor. MARTíN-BARBERO, Jesús. Televisão Pública, televisão cultural: entre a renovação e a invenção. In: Televisão Pública: do consumidor ao cidadão. Friedrich Ebert Stiftung. S. Paulo, 2002.

${ }^{70}$ Proposta pelo governador José Ivo Sartori (PMDB) e aprovada pela Assembleia Legislativa, a extinção de seis fundações estaduais, entre elas a Fundação Cultural Piratini Rádio e Televisão, é um dos projetos mais polêmicos do pacote apresentado para reduzir a máquina pública e amenizar a crise.

${ }^{71}$ Em 18 de janeiro de 2017, o ordenador de despesas e presidente da Fundação Piratini, Orestes de Andrade Jr., esteve no Ministério Público do RS e informou ao procurador-geral sobre as garantias para preservação do acervo histórico da instituição e a tramitação de sua extinção: "Queremos encontrar uma maneira sustentável de manter a TVE e a FM Cultura no ar", ressaltou o presidente, ao informar que os canais não serão desligados após a extinção final da Fundação. Orestes Jr. informou também que tratará do assunto com a máxima transparência possível e que conta com o apoio e a fiscalização dos órgãos de controle. Disponível em: $<$ http://www.tve.com.br/2017/01/fundacao-piratini-garante-preservacao-de-acervo-historico-da-tve-e-fmcultura-2/>. Acesso em 19 mai. 2017.
} 
favor do governo" (BUCCI, 2015, p. 39) ${ }^{72}$. E como conseguir isso? Nomeando seus gestores, o que se comprova com a rotatividade do cargo de diretor-presidente em um curto espaço de tempo como se observou entre maio e junho de 2016. Saída de Ricardo Melo, entrada de Laerte Rímoli, retorno de Melo. Este, ao reassumir fez um gesto de agrado a quem o nomeou, e de desagravo ao presidente que o exonerou. A TV Brasil gravou entrevista com Dilma Roussef no dia 5 de junho. $\mathrm{O}$ fato gerou ainda outro constrangimento ao governo interino: o entrevistador foi Luiz Nassif, que havia sido afastado por Laerte Rímoli. A entrevista foi anunciada para ir ao ar na terça-feira, dia 7 , às $22 \mathrm{~h}$, mas em seu lugar entrou um programa de música, sem explicações da emissora sobre a substituição. A entrevista acabou sendo transmitida pela TV Brasil, em parceria com a Rede Minas, estado também governado pelo PT, no dia 9 de junho, quinta-feira, às 22h. Depois do ocorrido, o Governo Federal anunciou unilateralmente corte de verbas e pessoal da EBC.

Em resposta às notícias de extinção da TV Brasil, entidades como o Conselho Curador da EBC, Sindicato dos Jornalistas Profissionais do Distrito Federal (SJPDF), Federação Nacional dos Jornalistas (FENAJ), Fórum Nacional pela Democratização da Comunicação, entre outras organizações da sociedade civil, saíram a campo para defender a "comunicação pública independente". Criaram a Frente em defesa da EBC e da Comunicação Pública e inundaram as redes sociais com depoimentos de intelectuais - brasileiros e estrangeiros defendendo a preservação da empresa.

A EBC também foi tema de uma audiência pública na Câmara dos Deputados, numa ação conjunta das comissões de Cultura, de Legislação Participativa, e de Direitos Humanos e Minorias e do FNDC. Em contraponto, o diretor de jornalismo da EBC, Lourival Macêdo, nomeado para o cargo pelo já afastado Laerte Rímoli, em artigo na Folha de S. Paulo (27/06/2016, A3), com o título $O$ Sequestro da EBC, fez duras críticas à atuação da EBC. “Espanta-me ver tanta ênfase naqueles que vociferam contra o 'golpismo' e hoje defendem, com indignação, um pluralismo que não praticaram na EBC (Empresa Brasil de Comunicação) ao longo dos últimos anos. Houve, isso sim, o sequestro de uma empresa pública por um grupo que representa uma corrente de pensamento", afirmou na abertura do texto. Jornalista oriundo da antiga Radiobrás onde atuou por 37 anos, Macêdo se apresentou como testemunha de que o jornalismo da EBC foi tomado pela "militância política". O diretor que se manteve no cargo mesmo depois da saída de Rímoli não poupou críticas à gestão que

\footnotetext{
${ }^{72}$ Bucci viveu a experiência como gestor, enfrentou resistências e buscou implantar a independência, primeiro de seus profissionais, depois, na relação com o governo, como ele relata no livro Em Brasília, 19 horas (2008).
} 
compartilhava com Ricardo Melo, que retornou ao cargo de diretor-presidente. Segundo Macêdo, nos oito anos de existência da EBC, ele é o primeiro diretor de jornalismo oriundo do quadro permanente da empresa. "Os demais, inclusive Ricardo Melo, foram 'importados do mercado"", escreve.

A resposta viria, no mesmo jornal, seis dias depois com a entrevista do diretorpresidente Ricardo Melo para a colunista Mônica Bergamo. TV Brasil é para dar voz a quem não tem, diz presidente $d a E B C$ foi a chamada para a longa entrevista pingue-pongue em que o diretor-presidente faz uma defesa contundente da empresa, negou o aparelhamento, destacou os principais compromissos, e justificou a baixa audiência (FSP, 03/07/2016, A9).

Mesmo com as críticas de movimentos sociais e organizações da sociedade civil e do próprio Conselho Curador em relação aos ataques da mídia, é preciso perguntar aqui por que toda essa hecatombe aconteceu na emissora que seria a mais pública das brasileiras, quando se prometia que o modelo escolhido garantiria sua continuidade e preservação de seu uso político? Quais as brechas na lei que criou a $E B C$ que não garantiram a independência em relação ao governo, incluindo aqui a escolha dos dirigentes? A junção da Radiobrás com a TVE Brasil que deu origem à $E B C$ e seu carro chefe, $T V$ Brasil, foi danosa? O que teria sido mais eficiente - a herança da estrutura estatal da Radiobrás, como aconteceu, ou a organização social que contemplava a Associação de Comunicação Educativa RoquettePinto? São questões que me debato ao longo deste trabalho, acrescentando ingredientes, como a MP $744^{73}$, que surgiram em meio ao turbilhão de mudanças que o pós-impeachment vem provocando.

Acompanhar as portarias de demissões e contratações disponíveis no portal da $E B C$ dá ideia do que acontece na instituição ${ }^{74}$. Trata-se do desmonte de um modelo, como aconteceu no passado nas mudanças de governo, ou um reajuste de parâmetros, como afirma o Conselho Curador ao longo de oito anos da $E B C$, como se lê nas atas de reuniões do colegiado? É bem mais que isso, pelo que se depreende e sigo observando: o retorno à estatal submissa ao rei.

\footnotetext{
${ }^{73}$ Medida Provisória 744/2016, altera a Lei $\mathrm{n}^{\circ} 11.652$, de 7 de abril de 2008, que institui os princípios e objetivos dos serviços de radiodifusão pública explorados pelo Poder Executivo ou outorgados a entidades de sua administração indireta e autoriza o Poder Executivo a constituir a Empresa Brasil de Comunicação - EBC. Extingue o Conselho Curador da EBC, que passa a ser administrada por um Conselho de Administração e por uma Diretoria-Executiva e, em sua composição, contará com um Conselho Fiscal. Cria uma nova composição ao Conselho de Administração da empresa. Reduz na composição da Diretoria-Executiva dois diretores e todos os membros passam a ser nomeados e exonerados pelo Presidente da República. e $<$ https://www25.senado.leg.br/web/atividade/materias/-/materia/126826>. Convertida na Lei $\mathrm{n}^{0} 13.417 \mathrm{de}$ $\underline{01 / 03 / 2017 \mathrm{n}^{\circ}} 13.417$ de $01 / 03 / 2017$. Disponível em: <http://www.planalto.gov.br/ccivil 03/ ato20152018/2017/lei/L13417.htm>. Acesso 5 mai. 2017

$74<$ http://www.ebc.com.br/institucional/acessoainformacao/institucional/portarias $>$.
} 
Volto a Germán Rey (2002) que analisa o contexto das televisões públicas naquele momento, início do século 21, com algumas reflexões bastante oportunas para o momento brasileiro. O livro foi uma espécie de preparação de fundo para as discussões que decorreram dali em diante, até a realização do Fórum Nacional das TV'S Públicas. Numa discussão que envolve a América Latina, os exemplos e análises de Rey, das televisões públicas contemplam países como Chile, Colômbia, Peru, Argentina, México e Brasil:

O que se deseja assinalar é a ideia de tirar a televisão do domínio e da orientação hegemônica do Estado, levando-a para uma autonomia social e política. Isto destacaria a necessidade de independência e a pertinência de uma atenção contínua a um setor mutável e exigente. A televisão desestatizada, moderniza-se sua gestão, situando-a de maneira pró-ativa perante o futuro (REY, 2002, p.100).

Acrescenta-se outra dimensão à problemática - se antes há a necessidade de separar Governo de Estado, aqui na proposição de Rey, discute-se a retirada até mesmo do domínio do Estado. Mas a Empresa Brasil de Comunicação criada pela Lei $\mathrm{n}^{\circ} 11.652$, de 7 de abril de 2008, limitou esta independência drasticamente no artigo 13, que definiu:

O Conselho de Administração, cujos membros serão nomeados pelo Presidente da República, será constituído: I - de 1 (um) Presidente, indicado pelo Ministro de Estado Chefe da Secretaria de Comunicação Social da Presidência da República; II - do Diretor-Presidente da Diretoria Executiva; III - de 1 (um) Conselheiro, indicado pelo Ministro de Estado do Planejamento, Orçamento e Gestão; IV - de 1 (um) Conselheiro, indicado pelo Ministro de Estado das Comunicações; e V - de 1 (um) Conselheiro, indicado conforme o Estatuto.

Ou seja, a escolha dos principais gestores estava a cargo do chefe do Governo, uma das questões que mereceram críticas de participantes do Seminário do Conselho Curador, que buscava avanço do modelo. A reviravolta no segundo semestre de 2016 foi um retrocesso ao implementar o mesmo modelo do período da Ditadura Brasileira, quando nasceram as televisões educativas: a Medida Provisória $744 / 2016^{75}$, que propôs a alteração da Lei $\mathrm{n}^{\mathrm{o}} 11.65 / 2008$, que criou a EBC. Aprovada na Comissão Mista do Senado Federal, e encaminhada à Câmara Federal, o que se viu com base no relatório do Senador Lasier Martins

\footnotetext{
75 MP publicada no Diário Oficial de $1^{\mathrm{o}}$ de setembro de 2016. Disponível em
} <http://www.planalto.gov.br/ccivil 03/ Ato2015-2018/2016/Mpv/mpv744.htm>. Acesso em 23 jan. 2017. 
(atualmente no $\operatorname{PSD}^{76}$ ) foi a proposta de uma empresa com outra configuração jurídica, agora mais governamental ainda. O relator, radialista gaúcho que fez sua carreira em rádio e televisão comercial no Rio Grande do Sul, manteve a extinção do Conselho Curador, que deveria ser o órgão forte representativo da sociedade, e propôs a criação de um Comitê Editorial e de Programação, com 11 membros, que se manterão distantes da gestão da empresa. Pela proposta, como descreve o senador, esse comitê poderá, caso não seja atendido pelo gabinete gestor, recorrer ao Senado Federal:

Ele vai cuidar da programação, que vai ser proposta para a diretoria da EBC. Se eventualmente a diretoria executiva da EBC não observar as sugestões, este comitê poderá se queixar para o Senado Federal, na sua comissão temática, no caso a Comissão de Comunicação, mostrando que tem sugerido, procurado fazer uma comunicação eficiente, de resultados, de audiência. ${ }^{77}$

O relatório do Senador Lasier Martins foi aprovado pela Câmara dos Deputados em sessão no dia 14 de dezembro de 2016. Logo depois, no dia 7 de fevereiro de 2017, o plenário do Senado Federal também aprovou a Medida Provisória que reformou a estrutura administrativa da EBC. Mantidas as principais modificações como a transformação do antigo Conselho Curador em Comitê Editorial, voltado para a definição da programação, e a aprovação pelo Senado do diretor-presidente da instituição. ${ }^{78}$

Volto às reflexões do livro Televisão pública: do consumidor ao cidadão em suas conclusões e destaco a descrição da diferença entre televisão pública e televisão de governo a que afirma que o caráter "público" advém de quem é seu proprietário (o Estado) mais do

\footnotetext{
${ }^{76}$ O senador anunciou no dia 06/02/2017 sua mudança de partido, depois de dois anos no PDT. Segundo ele, isso aconteceu por causa de divergências com a direção da legenda. Disponível em: $<$ http://www12.senado.leg.br/noticias/materias/2017/02/06/lasier-martins-anuncia-troca-de-partido $>$. Acesso em 22 fev. 2017.

${ }^{77}$ A comissão mista que analisa a Medida Provisória sobre a estrutura da EBC, a Empresa Brasil de Comunicação ( ${ }^{\circ}$ 744/2016), aprovou no dia 8 de dezembro de 2016 o relatório do senador Lasier Martins, do PDT gaúcho. O principal ponto do texto é a criação do Comitê Editorial e de Programação, que vai substituir o Conselho Curador, órgão extinto pela MP que contava com 22 representantes da sociedade civil e do governo. A principal diferença entre os dois órgãos é que o comitê, com 11 membros da sociedade civil, não terá nenhuma função de gestão na empresa, como tinha o conselho curador. Disponível em: $<$ http://www2.camara.leg.br/camaranoticias/radio/materias/RADIOAGENCIA/520980-COMISSAO-MISTADA-MP-DA-EBC-APROVA-RELATORIO-DO-SENADOR-LASIER-MARTINS.html>. Acesso em $14 \mathrm{dez}$. 2016.

${ }^{78}$ Senado aprova MP que reestrutura Empresa Brasil de Comunicação. Agência Senado. Publicado em 07 fev.2017. Disponível em: <http://www12.senado.leg.br/noticias/materias/2017/02/07/senado-aprova-mp-quereestrutura-empresa-brasil-de-comunicacao>. Acesso em 08 fev. 2017.
} 
que sua missão ou filosofia (servir o projeto ético da sociedade). Portanto, a televisão carece de um projeto que corresponda a um conceito contemporâneo de democracia ${ }^{79}$, cidadania, sociedade civil, consumo cultural, que lhes permita reinventar o caráter público a partir da televisão" (2002, p. 330).

A referência ao conceito contemporâneo de democracia e as circunstâncias deste momento no Brasil e no mundo reportam a Daniel Innerarity, em A transformação da política (2002), pelo senso de atualidade de seu texto: “A democracia e o mercado são instituições que vivem no meio de crises e desequilíbrios. Por isso, a incerteza e a instabilidade são características normais dos atuais processos políticos, sociais e econômicos" (INNERARITY, 2002, p.14).

Ainda de acordo com as conclusões do livro Televisão pública: do consumidor ao cidadão, o potencial transformador do conceito do caráter público estaria minado, "caso se referisse apenas ao aspecto governamental, o que o deixaria pleno de corrupção, má administração, e manipulação política" (2002, p.331). Levantam a seguinte questão: "onde reside a soberania da televisão pública? E citam Diego Portales e Teresa Otondo, que respondem que "na televisão privada residiria em cada proprietário; na televisão governamental, no governo (o diretor é nomeado e removido pelo presidente do País); na televisão pública, reside num regime legal e organizacional que garante a autonomia de gestão e a pluralidade e diversidade de suas mensagens".(2002, p. 331) O que se conclui é que não temos no Brasil uma televisão pública, mas televisões governamentais.

\subsection{Fragilidades e incertezas}

A instabilidade que se assiste nas televisões públicas também chamou a atenção de Teresa Otondo. ${ }^{80}$. As questões e reflexões por ela formuladas em relação à TV Cultura são oportunas: "Os Estatutos e o Conselho garantem a independência alardeada? Quais as bases da independência e da eficiência?". Na busca de respostas, pondera que "pelo contato frequente com as televisões da América Latina percebia que só as 'leis' não eram garantia suficiente de uma 'boa televisão'. As contingências políticas e econômicas geravam instabilidade contínua e, portanto, "má televisão"” (OTONDO, 2002, p.23) E isso não mudou.

\footnotetext{
${ }^{79}$ Grifo nosso.

${ }^{80}$ OTONDO, TERESA. Televisão Pública, para quem e para quê? São Paulo: Annablume, 2012.
} 
Não mudou no Brasil e tampouco na América Latina, como o exemplo da Argentina com a saída da presidente Cristina Kirchner e a entrada de seu opositor Maurício Macri. O presidente argentino fez as mudanças também mediante decreto ${ }^{81}$, o que provocou manifestações dos sindicatos das categorias profissionais ${ }^{82}$.

A pesquisadora Renata de Paula Trindade Rocha de Souza, em sua tese Políticas Culturais e Televisão Pública: o processo de conformação da Empresa Brasil de Comunicação/TV Brasil (2014) também se debruçou na tentativa de conceituar as emissoras estatais e públicas baseada em diferentes posicionamentos, como os adotados por Bucci, Chiaretti e Fiorini relativos aos três requisitos para ser uma emissora pública (já citados). Souza distinguiu, com base nas definições, as emissoras estatais por possuírem propriedade e natureza jurídica vinculada diretamente ou indiretamente ao Estado; "gestão cotidiana subordinada a autoridades de um dos três poderes da República; e, por fim, programação limitada às duas condições anteriores, a serviço das necessidades de divulgação de correntes da lógica interna do Estado" (SOUZA, 2014, p. 39). Para a pesquisadora, o conceito de televisão pública "possui uma perspectiva relacional, na qual suas principais determinantes dependem das condições intrínsecas da sociedade na qual este meio de comunicação se desenvolve" (Ibid, p. 40).

E são essas condições que buscamos para entender o ambiente que cerca as televisões públicas brasileiras. Para Bucci (2010), quando subordinada à orientação da autoridade estatal, a emissora pública não é pública de fato; sua linha editorial, sua programação e sua visão de mundo tendem a ser capturadas pela óptica estatal ou governamental, o que a distancia irreversivelmente dos pontos de vista próprios da sociedade civil. "A subserviência

\footnotetext{
${ }^{81}$ LA NACION - El Gobierno transfirió hoy (05/12/2016) el control de las señales Encuentro, Paka Paka y Depor TV, entre otras, al Sistema Federal de Medios y Contenidos Públicos de la jefatura de Gabinete, que encabeza Hernán Lombardi. A través del decreto 1222, publicado hoy en el Boletín Oficial, Mauricio Macri creó "Contenidos Públicos Sociedad del Estado" que gestionará y operará esos canales, que hasta ahora dependían del Ministerio de Educación. Disponível em: $<$ http://www.lanacion.com.ar/1962447-transfieren-a-hernan-lombardiel-control-de-paka-paka-encuentro-y-deportv>. Acesso em 16 jan. 2017.

${ }^{82}$ MET, CEA, CTERA, UDA y SADOP, los cinco sindicatos docentes nacionales, rechazan y repudian el Decreto 1222/16 - publicado en el Boletín Oficial - del presidente Mauricio Macri que transfiere el control de las señales Encuentro, Paka Paka y Depor TV al Sistema Federal de Medios y Contenidos Públicos, ya que eso significa que se deroga parte de la Ley de Educación Nacional (26.206), modificando los artículos 101, 102 y $142 . \quad$ Disponível em $<$ http://www.sadop.net/los sindicatos docentes rechazan el decreto que transfieren los canales educativos 2 1466>. Acesso em 16 jan. 2017.
} 
ao poder público, nesse caso, mais do que nociva, é mortal. Impede a emissora de transmitir um olhar crítico em relação ao poder" ${ }^{, 3}$, afirma.

É importante aqui refletir sobre a diferença entre governo, Estado e público. As instituições fazem parte do Estado. O governo deve gerir a "coisa pública", o que é muito diferente da noção de apropriação que acaba predominando no cenário latino-americano. Sob a perspectiva de que a TV pública não deve se submeter nem ao governo, nem ao mercado, observam-se na história algumas tentativas e acertos como, por exemplo, a BBC (Inglaterra) e a Fundação Padre Anchieta (São Paulo), esta em alguns momentos. Olhando para o Brasil deste 2017, permanece a noção de apropriação e não de gerência das instituições do Estado.

Ao tratar da arte de governar, em seu livro Microfísica do Poder $^{84}$, Michel Foucault ilustra, no capítulo $A$ Governamentalidade, uma parábola sobre o navio "que aparece em todos os tratados", e responde à pergunta $O$ que é governar um navio?

É certamente se ocupar dos marinheiros, da nau e da carga; governar um navio é também prestar atenção aos ventos, aos recifes, às tempestades, às intempéries, etc.; são estes relacionamentos que caracterizam o governo de um navio. Governar uma casa, uma família, não é essencialmente ter por fim salvar as propriedades da família; é ter como objetivo os indivíduos que compõem a família, suas riquezas e prosperidades; é prestar atenção aos acontecimentos possíveis, às mortes, aos nascimentos, às alianças com outras família; é esta gestão geral que caracteriza o governo e em relação ao qual o problema da propriedade fundiária para a família ou a aquisição da soberania sobre um território pelo príncipe são elementos relativamente secundários. O essencial é portanto este conjunto de coisas e homens; o território e a propriedade são apenas variáveis.

\subsection{O processo colombiano}

A Colômbia, outro campo de estudo desta pesquisa com sua televisão Señal Colombia, intensificou as discussões sobre televisão pública de qualidade no final do século 20. Conforme documento que recebi da ex-dirigente da Señal, Marcela Benavides ${ }^{85}$, lá também o Ministério da Cultura teve importante papel como propulsor dos debates, como será explicitado no capítulo 3. A largada desse processo foi em 1998 com o Plano de Educação e

\footnotetext{
${ }^{83}$ BUCCI, Eugênio. É possível fazer televisão pública no Brasil? São Paulo: Novos estudos. CEBRAP n ${ }^{\circ} 88$. $<$ http://www.scielo.br/scielo.php?script=sci_arttext\&pid=S0101-33002010000300001\#ntb $>$.

${ }^{84}<$ http://petletras.paginas.ufsc.br/files/2017/03/foucault-microfisica-do-poder.pdf>

${ }^{85}$ Estive com Marcela Benavides, em Bogotá, em 19 de novembro de 2015.
} 
Cultura implantado pelo então Instituto Nacional de Rádio y Televisión - Inravisón, ${ }^{86}$ que administrava a Señal Colombia. O plano pretendia "através de los medios masivos (...) subsanar las deficiências contemporâneas de la televisión pública a partir de la reestructuración de Señal Colombia" o que só aconteceria efetivamente em 2004. Era parte de um projeto nacional, de longo prazo, que permitiu agregar esforços e gerar um consenso em torno da construção e orientação da programação dos meios de comunicação públicos.

Destaco entre as iniciativas do Ministério da Cultura a de encomendar um estudo aos professores e teóricos de comunicação Jesús Martin-Barbero, Omar Rincón y Germán Rey que se constituiu em manifesto por uma televisão pública de qualidade, considerado "el insumo más influente en las mesas de trabajo", como classificou o Ministério da Cultura no documento. O texto elaborado pelos professores recebeu título de Televisión pública, cultural, de calidad e, nele, os professores descrevem o que se poderia chamar de televisão pública naquele momento, início deste século ${ }^{87}$, quando os debates ganhavam intensidade:

Las fuertes transformaciones que atraviesan los sistemas de televisión en el mundo están replanteando el sentido de la televisón pública y en especial de la televisón cultural. Desde Europa hasta América Latina los últimos años han presenciado un encendido debate sobre la función de la televisión a cargo del Estado y el significado de lo cultural en la televisón.

Já antes de toda a movimentação narrada pelos professores colombianos, a questão do significado da educação e da cultura nas televisões nomeadas "públicas" ou de gestão governamental, como as educativas, permeou também no Brasil os encontros do Sistema Nacional de Radiodifusão Educativa (SINRED) ${ }^{88}$, nos anos 1980, 1990, como já citado. Nesses encontros, se tratava, entre outros temas, do dia-a-dia das emissoras - das dificuldades e conquistas - e do intercâmbio de programação. Os programas, tanto de rádio como de televisão selecionados ou escolhidos, eram enviados pelas emissoras produtoras de distintas

\footnotetext{
${ }^{86}$ O Inravisión foi substituído, em 2004, pela RTVC -, Radio Televisón Nacional de Colombia, Sistema de Medios Públicos.

${ }^{87}$ REVISTA Gaceta, no 47. Bogotá, Ministério da Cultura, Dez. 2000, p. 50-61.

${ }^{88} \mathrm{O}$ objetivo principal do SINRED era o de permitir que todas as emissoras educativas veiculassem uma programação constituída por programas produzidos por todas as integrantes, diferentemente do que ocorria com as redes comerciais que se limitavam a retransmitir a programação das cabeças-de-rede localizadas, invariavelmente, no Rio de Janeiro e em São Paulo. (FRADKIN, Alexandre). Disponível em: $<$ https:/www.google.com.br/search?q=SINRED\&ie=utf-8\&oe=utf-8\&client=firefox-bab\&gws_rd=cr\&ei=DTGuWM-fGMGwwATm4pqoBA\#q=SINRED+-

+SISTEMA+NACIONAL+DE+RADIOS+E+TVS+EDUCATIVAS FNDC>. Acesso em 27 ago. 2016.
} 
partes do Brasil, via malote, correio e outros meios de transporte, para suas irmãs congêneres. Assim, se formavam as redes sob coordenação da TVE Rio. Eram "programas educativos e culturais", como eram classificados, por exemplo, os módulos de curta duração produzidos pela Rádio MEC, sobre Língua Portuguesa, Literatura, Cinema, Música - incluindo os vários gêneros: jazz, clássica e popular. Foi um período em que a apropriação dos termos educação e cultura justificou a distinção das programações das emissoras educativas em relação às comerciais. Como uma espécie de nicho para a elite, eram programações que agradavam aos letrados. Omar Rincón em depoimento a esta pesquisadora, ao se referir ao caso da Señal Colombia, observou, ao comentar fenômeno semelhante, que ao "povo não lhes atraía". Rincón, apesar de elogiar as gestões de Marcela Benavides e Jaime Tenório, os últimos dirigentes até então ${ }^{89}$ avalia:

(...) Entonces ellos se dedican a tratar temas que son importantes para la identidad pero que no son, a la final para el televidente cotidiano, al punto de tener poca importancia para los ciudadanos. Hacen buena televisión, muy buena, pero como el presupuesto de ellos no es muy alto, es una televisión anti televisiva. En dos sentidos. Es una televisión en que se produce muy poco. Entonces ellos hacen programas con que ganan premios internacionales y todas esas cosas. Pero hacen 10 capítulos de una serie y la televisión es 24 horas, entonces el televidente colombiano no ve Señal Colombia porque nunca sabe qué están pasando ni a qué horas lo están pasando. O sea, no hay una conexión entre lo que ellos hacen y la gente. Y esta falta de conexión se debe a dos cosas: una, a que no hay una producción estilo televisiva, de tener 50 capítulos, de tener unos rituales. No los tienen, hacen todo muy pequeño. Y lo segundo, es que a pesar de una estética muy buena, televisivamente bastante buena, me gusta, es una estética muy letrada y clase media. A mí me gusta, pero a mí mamá no le gusta. Mi mamá me dijo un día: "es que eso es como un restaurante donde venden una comida que no es para mí". Entonces es como si fuera una televisión para nosotros del mundo civilizado y letrado y no una televisión para el pueblo. Pero, ¿y no es publica?

Diferentemente da forma traumática como ocorreu na $E B C$ em 2016, a Señal Colombia também passou por mudança de gestor. Lá, o diretor da emissora, Jaime Tenório, com quem estive em novembro de 2015, renunciou ao cargo em fevereiro de 2016. Em uma troca de mensagens por email, que será reproduzida no próximo capítulo, ele informou que saiu por decisão pessoal, desestimulado pelas descontinuidades das gerências do órgão maior, a RTVC, este sim com nomeações políticas. Mas diferentemente do que ocorreu no Brasil,

\footnotetext{
${ }^{89}$ Jaime Tenório pediu seu afastamento no final de fevereiro de 2016. Diana Díaz Soto é a atual diretora da Señal Colombia.
} 
com a $E B C$ sua substituição foi elogiada pelo próprio Jaime. Em seu lugar foi nomeada Diana Díaz Soto, com larga experiência em televisão pública, com passagens pela Señal Colombia. Antes de assumir a direção do canal, ela respondia pela coordenação do Proyecto de Comunicación, Cultura y Niñez del Ministerio de Cultura en la Dirección de Comunicaciones com atuação relacionada às televisões públicas de todo o país. Estive com Diana Díaz Soto em 17/11/2015 e, na entrevista, ela contou sobre os momentos das mudanças que deram origem ao que é a Senãl hoje, o que será detalhado no capítulo 3.

Este foi um processo de nomeação que contou com uma convocatória, ou seja, uma seleção, e a escolha foi, como se depreende, por experiência e conhecimento da instituição. E isso, Diana tinha, como testemunhei em Bogotá ao encontrá-la no Ministério da Cultura.

Me restringi neste texto a adotar alguns conceitos de televisão pública, evitando entrar na complexidade da noção de comunicação pública. Segundo Guilherme Fragas Nobre ${ }^{90}$, há um mosaico que corporifica a comunicação pública. Para ele, não basta que as mídias fiscalizem o governo e as universidades inovem junto com as empresas; o ideal é que todos os comunicadores públicos se fiscalizem uns aos outros, informem-se, debatam, mobilizem, engajem-se mutuamente (2011, p.262). Mesmo sem aprofundar a noção de comunicação pública, recorro a uma afirmação de Maria Helena Weber (2017, p.26) pelo que identifico com as ocorrências constatadas, de que "a associação sumária do conceito 'público' às instituições do estado democrático pode mascarar e subverter ações de interesse privado, entendido este como privilegiando determinados governantes e seus dependentes familiares ou políticos".

Diante dos acontecimentos que impactaram essa pesquisa, atenta aos desdobramentos e inspirada pela sugestão de Nobre de que "nos fiscalizemos uns aos outros", tratarei nos capítulos seguintes das trajetórias das emissoras Señal Colombia e TV Brasil, apontando os solavancos que sofreram com interferências e descontinuidades em seus percursos.

\footnotetext{
${ }^{90}$ NOBRE, G.F. Capital Social, comunicação pública e deliberação: a gestação do capital comunicacional público. In Comunicação e política - Capital social, reconhecimento e deliberação pública. São Paulo: Summus, 2011.
} 


\section{Televisão pública: riscos e recuos, o denominador comum}

Señal Colombia e a TV Brasil iniciam seus caminhos no século passado, com trajetos distintos, para renascerem no século 21 com novos nomes e vínculos. Destaco esse fato para lembrar que essas duas televisões "públicas" não nasceram do zero nos anos 2000: partem de embriões de empresas governamentais e continuam sendo, ainda hoje, como vou recuperar aqui. As mudanças de gestão nas trocas de governo têm marcado as trajetórias dessas instituições.

\subsection{Primórdios da televisão pública colombiana}

Elejo, para começar como um critério de temporalidade, a colombiana Señal Colombia, que teve suas raízes como empreendimento governamental na Televisão Nacional nos idos de 1954. Essa foi a primeira televisão na Colômbia e se estabeleceu como televisão governamental. No Brasil, nesse período já dominavam as televisões comerciais que reinaram absolutas até o surgimento da televisão educativa, durante a Ditadura Militar de 1964. Em 1970, o presidente da Colômbia, Carlos Lleras Restrepo, inaugurou o canal 11, uma cadeia de televisão nacional, com caráter eclusivamente educativo. Esse canal se transformaria em, 1995, na Señal Colombia.

Para entender momentos da história da televisão colombiana me valho de documento recente, o Boletín Cultural Y Bibliografico, lançado em 2015 pela Biblioteca Luis Ángel Arango, em homenagem aos 60 anos da televisão colombiana, inculindo os 15 anos dos canais privados. Reúno também depoimentos de profissionais e especialistas ouvidos em Bogotá $^{91}$. Entre os autores do Boletín estão o jornalista e escritor Andrés Arias, o jornalista Javier Darío Restrepo, a "editora convidada" Paula Arenas e o professor e crítico de televisão Omar Rincón. Os recortes são feitos de acordo com fatos que procuro examinar para entender o uso político dessas televisões. E por aqui me deparo com a questão que permeia esta pesquisa: Por que os interesses de governo e de partidos têm vencido a mobilização de entidades da sociedade civil, da academia e de profissionais organizados em movimentos pela defesa da televisão independente e autônoma, ou seja, a nomeada pública?

\footnotetext{
${ }^{91}$ Viagem de pesquisa à Bogotá, Colômbia, no periodo de 17 Nov. a 25 Nov. 2015.
} 
A Televisão Nacional da Colombia, como a TVE do Rio de Janeiro, surge em um governo militar. Inaugurada em 13 de junho de 1954, data em que o general Gustavo Rojas Pinilla comemorava seu primeiro ano de governo tomado por um golpe de estado. Para a implementar o projeto de televisão foi convidado Fernando Gómez Agudelo, um jovem que dirigia a Radiodifusora Nacional de Colombia (Cf RESTREPO, Javier Dario, 2015 ${ }^{92}$ ). A implantação foi rápida - oito meses entre o convite a Agudelo, em outubro de 1953, e a inauguração do canal de TV (El Tiempo, 21/08/2014). Gómez Agudelo contou com a colaboração de outro jovem, o engenheiro elétrico Fernando Restrepo, que se dedicou às questões técnicas.

O general Jefe Supremo, como Rojas Pinilla exigia ser chamado, recordou no discurso de inauguração que conhecera a televisão ainda como major do exército, em uma visita à Alemanha, 18 anos antes, e desde então acalentou o sonho de trazer a televisão para a Colômbia. Esse discurso foi transmitido ao vivo para cerca de 1.500 "televisores" além do público que se aglomerava em frente às vitrines de lojas (RESTREPO, ibid). Terminado o discurso do chefe supremo, as transmissões naquele primeiro dia seguiram do estúdio. Omar Rincón ${ }^{93}$ descreveu as primeiras transmissões: "En la primera emissión El niño del pântano, una breve de ficción adaptada para televisión de un cuento original de Bernardo Romero Lozano, ya marcaba el rumbo". Era a telenovela que nascia a partir do rádio. E a programação seguiu variada naquela estreia - um concerto com o violinista Frank Preuss e a pianista Hilde Adler, seguido de um noticiário internacional, e apresentação de uma dupla de músicos populares, Los Tolimenses (ARIAS, 2015).

O número de "televidentes" cresceria até o final daquele ano, quando começou a operar uma rede de 14 estações, com alcance a todo o território nacional. Prometiam uma programação estritamente educativa. Não foi o que aconteceu, como relata Javier Restrepo, a partir de citação da revista Semana (de 14 fev. 1955): "Sin embargo, ya comenzaban las protestas debido al contenido violento de las películas e vaqueiros de México y los Estados Unidos con su "exaltación de las hazañas de gángsteres y de cowboys"”. As reclamações em relação à programação atingiram também a figura do presidente pelo "propósito

\footnotetext{
${ }^{92}$ RESTREPO, Javier Darío. Sessenta años esperando la democracia. In: Boletín Cultural y Bibliográfico. Homenaje a la television colombiana. Biliboteca Luis Ángel Arango, Bogotá, 2015.

${ }^{93}$ RINCÓN, Omar. La television Colombia es de autor. In Boletín Cultural y Bibliográfico. Homenaje a la television colombiana. Biliboteca Luis Ángel Arango, Bogotá, 2015.
} 
propagandístico" que mantinha na tela sua imagem e suas ações, relegando os projetos educativos, de entretenimento e de informação (RESTREPO, 2015).

Como no Brasil, no período da Ditadura, a censura foi implacável. A informação era controlada por censores que operavam nos jornais e no rádio. Não atuavam sobre a Televisão Nacional, porque esta era do Estado e já estava sob controle. Em dezembro de 1955 passam a ser transmitidos os serviços de informação de uma agência internacional, a Telenews. Permanecia, no entanto, a supremacia da presença do presidente na tela. Rojas Pinilla governou o país de 13/06/1953 a 10/05/1957. Fernando Gomez Agudelo deixaria a direção da emissora um ano depois da saída do general Rojas Pinilla, durante o governo do liberal Alberto Lleras Camargo (presidente do país em duas ocasiões: entre 1945 e 1946, e de 1958 a 1962), como escreve André Arias (2015). ${ }^{94}$ Esses fatos determinaram a primeira mudança na Televisão Nacional.

As considerações acima indicam que o uso político do veículo já se manifestava ali. Segundo Arias (2015), Gomez Agudelo foi substituído por Fernando Restrepo, seu companheiro na implantação da televisão. São reconhecidos o esforço e dedicação dos dois "Fernandos" para colocar em funcionamento a primeira televisão colombiana. Gómez Agudelo era o criativo, gostava de música de concerto, se relacionava com escritores, roteiristas e atores. Já Fernando Restrepo, um engenheiro elétrico, "siempre ha sido hacer empresa: el es de números, de grandes proyectos, de cubrimiento, de pensar a largo prazo", contou Patricio Wills, sócio dos "Fernandos" em uma produtora (RTI), em depoimento a Andrés Arias (2015). Fernando Restrepo ficou na direção da Televisão Nacional nos quatro anos de Alberto Lleras Camargo. Apesar de ter trabalhado no governo anterior, a ditadura de Rojas Pinilla - "como contratista", no como empleado" (ARIAS, 2015), Fernando era identificado como um liberal - seu pai, Fabio Restrepo, foi o primeiro presidente do jornal $E l$ Tiempo.

Para além dos usos políticos, essa televisão ousou em alguns programas, como constatei no Museo Nacional de Colombia. A crítica de arte Marta Traba dirigiu e apresentou,

\footnotetext{
${ }^{94}$ ARIAS, Andrés. Restrepo y Gómez Agudelo: los tele-videntes. In: In Homenaje a la television colombiana. Boletín Cultural y Bibliográfico. Biliboteca Luis Ángel Arango, número 87. Bogotá, 2015.

${ }^{95}$ Contratados para um serviço especial.
} 
entre 1954 e 1958, cinco programas sobre $\operatorname{arte}^{96}$ (ARENAS, 2015), em que interagia com o público. Marta se deslocava para a rua, circulava em meio aos transeuntes, percorria espaços públicos para apresentar a arte como "afeta" (MEDINA, 2003 p. 59) aos colombianos.

Em entrevista a Andrés Arias (2015, p.11), já nos seus 81 anos, Fernando Restrepo recordou que a programação foi se ajustando aos poucos. No dia seguinte à inauguração se deram conta de que não tinham programas para levar ao ar. Como Gómez Agudelo vinha do rádio, as radionovelas se converteram em telenovelas - "muy sensilla y elemental en cuanto producción, aunque la calidad autoral fuera bueníssima". Tudo era ao vivo, inclusive a publicidade. As empresas passaram a se interessar por fazer comerciais e a patrocinar programas, entre eles, “um noticiário patrocinado pela Avianca e outro por Suramericana” (In ARIAS, 2015).

Patricia Castaño ${ }^{97}$, ouvida em Bogotá ${ }^{98}$, produtora, com larga experiência em cinema documental e televisão, e uma das propulsoras, junto com Adelaida Trujillo, dos debates sobre televisão pública de qualidade na Colômbia, se refere ao início da televisão como "muito artesanal e interessante". Porque se desenvolveu a partir da Radio Teatro Nacional, "la cimiente de las telenovelas; era teleteatro en vivo". Segundo Castaño, durou muito pouco a imagem da TV em poder do governo, "sobretudo de um governo autoritário", o que fez com que começassem as pressões para que os particulares tivessem acesso à programação. "Es decir, que la idea de una TV pública se confundió con la idea de una TV de gobierno. Aquí no entendieron que la BBC era independiente, ni Rojas Pinilla ni los demás". Mas fez uma ressalva, destacando a percepção dos fundadores Gomez Agudelo e Restrepo sobre a televisão:

\footnotetext{
${ }^{96}$ Nesse período, Marta Traba dirige La rosa de los vientos, e quatro programas culturais: El museo imaginario, Una visita a los museos, El ABC del arte moderno e Curso de historia del arte. (ARENAS, 2015) Marta faleceu em um acidente aéreo junto com o esposo, o crítico literário Angel Rama.

${ }^{97}$ Patricia Castaño formada em "trabajo social y comunicación rural" nos anos 1970 na Colômbia, Inglaterra e Holanda, dedicou-se ao cinema e televisão documental. Com uma bolsa do Conselho Britânico por seu trabalho na Colombia com a BBC e televisão pública e educativa, estudou na Inglaterra cinema e televisão com a BBC e Open University. Em 1986, criou, com Adelaida Trujillo e Doris Eder, a Citurna Producciones, líder na Colômbia em produções para cinema e televisão documental e infantil. Também fundou com Adelaida e outros sócios a Fundación Imaginario, para trabalhar de forma ampla e interdisciplinar com a televisão, os meios e a comunicação como parte de estrategias para a educação e as mudanças sociais. Patricia teve importante papel nas articulações para o desenvolvimento da televisão pública na Colombia, como organizadora de eventos entre eles, o Prix Jeunesse. Foi membro da Junta Diretiva Internacional do INPUT e do grupo de produtores latinoamericanos que promovem Prix Jeunesse. É citada por todos os ouvidos nesta pesquisa como a mestre.

${ }^{98}$ Encontro ocorrido no dia 22 nov. 2015.
} 
Curiosamente, los que más defendieron eso fueron los dos primeros directores de la TV en el gobierno de Rojas Pinilla que eran Fernando Gómez Agudelo y un señor que se llamaba Fernando Restrepo Suárez (...). Ellos fueron los primeros que dijeron: "No. Esto no se puede quedar en manos del gobierno", y vieron el negocio, que era un buen negocio, entonces fundaron una programadora ${ }^{99}$ que se llamaba RTI pero luego empezaron a surgir unas cinco ó seis programadoras importantes (...)

Na sequência à criação da televisão, em 1955 foi criada a Televisora Nacional, uma espécie de produtora, comandada pela Oficina de Información e Prensa del Estado (Odipe), para "prestar serviço público de televisão". As linhas definidas pelo governo para este novo meio de comunicação afastavam radicalmente qualquer intenção democratizadora, como defendiam os dirigentes Gomez Agudelo e Fernando Restrepo. "Para Rojas y su comunicador de cabecera, el abogado Jorge Luis Arango, la televisión era, antes que cualquiera otra cosa, un instrumento de propaganda, como en cualquier ditadura". No primeiro ano de atividades, sob a direção de Arango, a Odipe (similar ao DIP no Brasil) tinha três objetivos: "difundir y exaltar la imagen del presidente, controlar las informaciones para impedir que las versiones de la oposición llegaran a la opinión pública y montar un poderoso dispositivo de propaganda para dar a conocer al país y al mundo, las realizaciones del gobierno militar". Para Javier Restrepo (2015), se no início a informação da televisão foi controlada pelo poder presidencial, essa submissão ficou como sua marca de origem. "La falta de crítica, impuesta por el régimen, unida a la escassa información, alejaria las possiblidades democratizadoras de la televisión" (Ibid 2015).

Os anos que se seguiram não mudaram muito a fórmula. Segundo Paula Arenas ${ }^{100}$, conhecedora da história da televisão pública da Colômbia, que em 2015 atuava como assessora de conteúdos da RTVC Sistema de Medios Públicos, o "duopolio RCN-Caracol se parece mucho al bipartidarimo del Frente Nacional que caracterizó el sistema político colombiano durante 16 años (1958 e 1974) que nos heredó costumbres excludentes y nos dejó pequenos movimientos y partidos, que siguen débiles en la lucha por la supervivência".

A subjugação aos interesses políticos permaneceu por longo tempo. Os partidos políticos disputavam os espaços, como denunciou o jornalista Luis Carlos Galán, em artigo

\footnotetext{
${ }^{99}$ A produtora RTI - Radio Televisión Interamericana - foi criada em 1963. Foi uma das maiores produtoras da Colômbia. Disponível em: <https://www.foromedios.com/topic/51077-rti-producciones-\%C2\%BFmuerto-oest $\%$ C3\%A1-de-parranda/>. Acesso em 24 abr. 2017.

100 ARENAS, Paula. El futuro de la televisión pública educative y cultural. El caso Señal Colombia. In: Homenaje a la television colombiana. Boletín Cultural y Bibliográfico. Biliboteca Luiz Luis Ángel Arango, número 87. Bogotá, 2015.
} 
publicado na Nueva Frontera (10/09/1976), em um dos momentos de pressão dos políticos para tomar a televisão em 1976: "la televisón es de todo los colombianos, fue el Estado quien adquirió los equipos desde 1954, por tanto no debe ser un instrumento de ninguna facción". (In RESTREPO, 2015:33). Esse jornalista e também político, que seria candidato a presidente da Colômbia em dois momentos, em 1982, pelo Nuevo Liberalismo, movimento político criado por ele, e novamente, nas eleições de 1986, desta vez como candidato independente, continuou crítico ao uso político da televisão. Foi uma voz dissonante de seus pares ao denunciar a disputa dos partidos pelos espaços televisivos.

E, nesse ambiente, os interesses comerciais passam a disputar espaço na emissora “governamental”. Começam as licitações e convites para esse único canal, privilegiando programadoras, que já mostravam sua força. Quatorze meses depois da criação da TV colombiana, o governo determinou a utilização de alguns espaços da Empresa de Televisión Comercial (TVC) ${ }^{101}$ (Ibid, 2015, p.36) e logo as agências de publicidade tomam os horários de maior sintonia. O telespectador passou a ser alvo de um mercado disputado pelos programadores de televisão. As cadeias de rádio - Caracol e RCN - propuseram ao governo a venda ou aluguel da televisão nacional para exploração comercial (RESTREPO, Cf. El Siglo, 10/12/1957).

A discussão sobre a "liberdade de canais ${ }^{102 "}$ se estendeu com contrários e favoráveis. Em entrevista ao El Tiempo, o reitor da Universidad de los Andes, Mario Laserna, identificou a iniciativa de "liberdade dos canais", como de interesse das agencias de publicidade. Projeto apresentado na época definia como papel dos canais do estado, as tarefas educativas; e dos canais privados, comandados por publicitários, de interesse de ordem econômica e política. (Grifo nosso). "Una vez dueños de los médios de difusión, los publicistas entraran en posesión de los sentimientos, ideas y emociones de los cuidadanos", afirmou Larserna (Cf. RESTREPO, 2015). Era o ingresso dos grandes grupos de comunicação no negócio de

\footnotetext{
${ }^{101}$ A mediados de agosto de 1955, se creó el modelo de televisión mixto, único en América. El Gobierno Nacional delega a la empresa Televisión Comercial -TVC- (sociedad constituida por las empresas radiales Caracol y RCN), la explotación comercial de algunos espacios en la programación del canal nacional. Entre 1956 y 1957 se crearon las primeras programadoras de televisión en Colombia: Producciones PUNCH y TVC Ltda. en la entonces Televisora Nacional de Colombia, actual Canal Uno. CF. $<$ https://pt.slideshare.net/juancarlosrestrepo/presentacin-television>. Acesso em 24 abr. 2017.

${ }^{102}$ As discussões sobre a liberdade de canais iniciaram quando o ministro de Comunicações colombiano anunciou, em 1965, a possibilidade de uma liberdade de canais por decreto legislativo, o que provocou intensa polêmica e satisfez aos empresários. Um editorial do El Tiempo (8/12/1965) qualificou o anúncio como brincadeira de mau gosto, "capricho individual para amparar negócios' que debería decidirse en el Congresso y no imponerse con las facultades de Estado de Sitio, vigentes en esse momento". (RESTREPO, Javier, 2015, p.38)
} 
televisão. Diante da necessidade de um ordenador para operar as emissoras governamentais foi criado, em 1963, o Instituto Nacional de Radio y Televisión (Inravisión), ${ }^{103}$ encarregado de prestar serviço público de rádio e televisão, incluindo a definição da grade de programação.

As estripulias políticas não cessaram. Mais tarde, em 11 de agosto de 1991, o $E l$ Espectador publicou denúncia do presidente do Centro Andino de Estudios, Gerney Ríos González: "el privilegio más antipático en Colombia, es la preferencia por los hijos de las famílias presidenciales, de los noticieros de televisión" (RESTREPO, 2015, p. 34). A denuncia devia-se à licitação para produção dos noticiários em TV pública feita naquele ano, que favorecia os filhos de políticos liberais e conservadores. A informação (notícias) gerada pelas emissoras governamentais continuava distante das possibilidades democratizadoras que se prometeu em sua criação (Ibid, p.34). Os críticos, no entanto, continuaram lutando. O jornalista e líder político Luis Carlos Galán voltaria a se manifestar na véspera da licitação de 1983, em carta dirigida ao ministro das Comunicações, Bernardo Ramirez. Segundo Restrepo, o jornalista estava consciente da contradição entre a natureza da televisão em mãos do Estado e a da prática deste meio em mãos dos "delfines". Galán recomendou ao ministro: "Primero: reducir el numero de noticieros. Segundo: disponer que estos se entreguem a periodistas profesionales, especialmente equipos de periodistas de distintas ideologias para garantizar la pluralidade". Galan esboçava o projeto de uma televisão autônoma e independente.

Segundo ainda Restrepo (2015, pag. 34), uma das licitações realizada em 1983 apresentava nos informativos oficiais a distribuição dos espaços para partidos políticos assim definido no Comunicado do Inravisón, de 7 de novembro de 1983: "Intervisión, 23:30, de extracción liberal; Telediario,12:30, de extracción conservadora; 24 Horas, 7:30, de extracción conservadora; Noticiero Nacional, 9:30, independiente". Como se pode perceber, os melhores horários eram reservados aos partidos conservador e liberal. A recomendação do líder político Luis Carlos Galán, como relata Restrepo (2015), não teve ressonância. Nova licitação aumentou os informativos e a justificativa era de que "não se podia deixar o presidente Julio César Turbay sem espaço nos noticiários", comentou o jornalista Azriel Bibiowicz, reconhecido escritor na Colômbia, que completava: "la despolitización de los noticieros es una ilusión”.

\footnotetext{
${ }^{103}$ O Instituto vai existir até 2004, quando é substituído pela RTVC - Rádio e Televisão Pública da Colombia, que administra hoje a Señal Colombia, entre outros veículos.
} 
O comentário do jornalista se comprovaria três anos depois, no período pré-eleitoral, quando participaram candidatos dos partidos liberal, independente e conservador. Destaco a minutagem dos tempos no ar como uma amostra do que acontecia. O telejornal Noticiero Cinevisión, por exemplo, não teve pudor ao dar primazia de espaço televisivo ao seu candidato: o liberal Virgilio Barco teve o maior tempo na tela, 128'12", enquanto os concorrentes Álvaro Gómez (conservador), 55’25”; e Luis Carlos Galán, (independente), 20'53”. Isso se repetiu em outros noticiários do dia (RESTREPO, p.35).

Como escreve Paula Arenas ${ }^{104}$, a chegada dos novos canais daria incremento à televisão comercial. Em 1965 é criado o Canal 9 (Teletigre), cuja exploração coube por licitação à jornalista Consuelo de Montejo, que ficaria com a emissora no ar por um período de cinco anos. Perdeu a concessão durante o governo do presidente Misael Pastrana (1970 1974), quando o canal 9 voltou às mãos do estado. Cinco anos depois, em 1970, é inaugurado o Canal 11, "a terceira cadeia de televisão nacional, com caráter educativo". O projeto era dedicado à capacitação popular, e iria se converter, em 1995, na Señal Colombia. Merece destaque a criação da produtora Audiovisuales (em 1970), com o objetivo de produzir programas para difundir notícias estatais. Na sequência, a Audiovisuales é encarregada de produzir também televisão educativa e cultural.

Os canais regionais surgem nos anos 1980, na seguinte ordem: 1985, o Teleantioquia; um ano depois, são lançados dois canais - Telecaribe e Telepacífico. E, em 1997, o Telemedelin, o primeiro canal local da Colômbia. Patricia Castaño conta que esses canais começam a brotar pelas regiões do país (Antioquia, Caribe, Medellin, Pacífico colombiano etc), mas sem muita clareza política. Surgem como canais de serviços públicos, independentes e autônomos - inicialmente deveriam ser financiados pelas regiões - mas acabam por ser parte da rede nacional de canais públicos, financiados principalmente pela Comisión Nacional de Televisión ${ }^{105}$ (CNTV). Essa comissão foi criada pela lei $182 \mathrm{em} 1995$ durante o governo de Ernesto Samper (1994-1998), e votada pelo Congresso da República. Teve como objetivo

\footnotetext{
${ }^{104}$ ARENAS, Paula. El futuro de la televisión pública educativa y cultural. El caso Señal Colombia. Boletim Cultural y Bibliografico, Número 87. Biblioteca Luis Ángel Arango, Bogotá, 2015.

${ }^{105}$ A CNTV foi criada pela Lei 182, de 1995. "Por la cual se regulamenta el servicio de televisión y se formulan políticas para su desarrollo, se democratiza el acceso a éste, se conforma la comisión nacional de televisión, se promueven la industria y actividades de televisión, se establecen normas para contratación de los servicios, se reestructuran entidades del sector y se dictan otras disposiciones en materia de telecomunicaciones". Disponível em: $\quad<$ http://www.col.ops-oms.org/juventudes/Situacion/LEGISLACION/PARTICIPACION/PL18295.htm>. Acesso em 13 abr. 2017.
} 
regulamentar o serviço de televisão e traçar suas diretrizes. Nas Disposições gerais, o artigo $1^{\circ}$ informava:

\begin{abstract}
Naturaleza jurídica, técnica y cultural de la televisión. La televisión es un servicio público sujeto a la titularidad, reserva, control y regulación del Estado, cuya prestación corresponderá, mediante concesión, a las entidades públicas a que se refiere esta ley, a los particulares y comunidades organizadas, en los términos del artículo 365 de la Constitución Política. Técnicamente, es un servicio de telecomunicaciones que ofrece programación dirigida al público en general o a una parte de él, que consiste en la emisión, transmisión, difusión, distribución, radiación y recepción de señales de audio y video en forma simultánea. Este servicio público está vinculado intrínsicamente a la opinión pública y a la cultura del país, como instrumento dinamizador de los procesos de información y comunicación audiovisuales.
\end{abstract}

Esse artigo definia o controle e regulação do Estado, a vinculação com a opinião pública e a cultura do país. O capítulo seguinte tratou da organização e estrutura da comissão a ser gerida por uma Junta Diretiva composta por cinco membros "eleitos ou designados": dois (2) pelo Governo Nacional, um (1) indicado pelos representantes legais dos canais regionais de televisão, um (1) escolhido a partir de listas apresentadas por associações profissionais e comerciais legalmente constituídas e reconhecidas pelas organizações envolvidas com a televisão, como diretores e roteiristas, produtores, técnicos, jornalistas e críticos de televisão -, e, nesse caso, a escolha a partir dessa lista seria pela Câmara dos Deputados. Outro membro seria escolhido de listas apresentadas pelas ligas e associações de espectadores, com personalidade jurídica, associações de pais, também com personalidade jurídica reconhecida, pesquisadores vinculados a universidades e academias colombianas reconhecidas pela lei, em conformidade com o Regulamento emitido pelo Governo, e escolha final pelo Senado. O mandato deveria ter validade de quatro (4) anos, coincidentes com o do Presidente da República e dos parlamentares do Congresso, e não reelegíveis. (No Brasil, a lei de criação da EBC determinava que o mandado do presidente da EBC, também de quatro anos, não poderia coincidir com o do presidente da República).

Algumas cláusulas do Título II, Capítulo 1, determinavam as funções da CNTV, entre elas, a definição de taxas a serem cobradas dos concessionários de serviços (o que também se tenta no Brasil). Assim, cabia à CNTV fixar os direitos, taxas e impostos a serem recebidos pela outorga, exploração das concessões para a operação de serviço de televisão e as taxas relativas aos contratos de concessão de espaços da programação, assim como da reserva, 
atribuição e utilização de frequências E ainda informava, no art. 17, como seriam usados esses recursos, como transcrevo a seguir:

De la promoción de la televisión pública. La comisión nacional de televisión efectuará el recaudo de las sumas a que tiene derecho y llevará su contabilidad detalladamente. Una vez hecha la reserva prevista en esta ley para absorber sus pérdidas eventuales, un porcentaje de las utilidades de cada ejercicio se depositará en un fondo denominado "fondo para el desarrollo de la televisión", constituido como cuenta especial en los términos del artículo $2^{\circ}$ del Decreto 3130 de 1968 , adscrito y administrado por la comisión, el cual se invertirá prioritariamente en el fortalecimiento de los operadores públicos del servicio de televisión y en la programación cultural a cargo del Estado, con el propósito de garantizar el pluralismo informativo, la competencia, la inexistencia de prácticas monopolísticas en el uso del espectro electromagnético utilizado para el servicio de televisión y la prestación eficiente de dicho servicio. ${ }^{106}$

Também foi definido o papel que caberia ao Inravisión e a composição de sua Junta Administrativa, assim designada:

a) El Ministro de Comunicaciones o su delegado, quien la presidirá;

b) El representante legal de la empresa nacional de telecomunicaciones o su delegado;

c) El representante del máximo ente gubernamental especializado en la promoción de la cultura;

d) Un delegado de la junta directiva de la comisión nacional de televisión;

e) Un delegado de los concesionarios de espacios de televisión, y

f) Un delegado de los trabajadores de Inravisión designado por ellos mismos.

El director de la entidad asistirá por derecho propio a las reuniones de la junta, con derecho a voz pero sin voto.

De la junta administradora regional harán parte, además de las personas que se determinen en sus estatutos:

- Un miembro de la junta directiva de la comisión nacional de televisión o su delegado.

La junta administradora regional será presidida por uno de sus integrantes, de acuerdo con lo que determinen sus estatutos.

A la junta administradora regional le corresponderá la adjudicación de los contratos de cesión de derechos de emisión, producción y coproducción de programas informativos noticieros y de opinión.

A CNTV, apesar de toda a complexidade prevista na Lei, recebeu críticas. Segundo Patrícia Castaño, "a Comissão Nacional de TV foi um foco de corrupção espantosa":

\footnotetext{
${ }^{106}$ Ibid - Disponível em: $<$ http://www.col.opsoms.org/juventudes/Situacion/LEGISLACION/PARTICIPACION/PL18295.htm>. Acesso em 13 abr. 2017.
} 
Y cuando leí esa ley me pareció lo máximo, que era una idea brillante, pues era una manera de financiar y regular todo el concepto de televisión pública, la Señal Colombia que era la Señal Nacional y los canales regionales. Lo que no me di cuenta era que el cáliz envenenado estaba en la manera cómo se elegían los miembros de la comisión. Habían miembros que eran los representantes del Congreso, los representantes de las organizaciones de televidentes que no existían, estaban las asociaciones de facultades de comunicación teóricamente, los representantes de gobernadores, un representante del presidente, además era una tragedia porque además del hecho de que fueran seis (6) siempre hizo que tuvieran que corromperse (eran las facultades de comunicación y educación, los representantes de los canales regionales no de los gobernadores, esos cargos los habían creado el gobernador del estado local, los representantes de las organizaciones de televidente, ese no era muy sólido. Era para ser lo más independiente y se volvió el más corrupto). En todo caso esto fue la tragedia más espantosa porque los salarios eran superiores a los salarios de un ministro. La Radio Televisora Nacional era financiada en parte por Telecom (empresa de telecomunicaciones) dueña de las redes. RTVC se crea después en 2004.

A CNTV seria substituída em 2012 pela Autoridad Nacional de Televisión - ANTV ${ }^{107}$, que incorporou todas as funções da entidade anterior:

Somos la Autoridad Nacional de Televisión - ANTV, la Agencia Nacional Estatal de Colombia, creada mediante la Ley 1507 de 2012, que tiene por objeto:

- Brindar las herramientas para la ejecución de los planes y programas de la prestación del servicio público de televisión, con el fin de velar por el acceso a la televisión, garantizar el pluralismo informativo, la competencia y la eficiencia del servicio.

- Ser el principal interlocutor con los usuarios y la opinión pública en relación con la difusión, protección y defensa de los intereses de los televidentes.

La ANTV está conformada por una Junta Nacional de Televisión, un Director y cuenta con el apoyo financiero del Fondo para el Desarrollo de la Televisión (Fontv ${ }^{108}$ ).

La Entidad trabaja en seis áreas misionales, distribuidas en coordinaciones y grupos de apoyo: Asuntos concesionales, Fomento de la industra, Regulación, Vigilancia, Control y Seguimiento, Técnica, Contenidos.

Um percurso resumido da história da televisão pública recebi de Marcela Benavides, em uma apresentação preparada por ela. A apresentação descreve as mudanças até os dias de hoje: “o INRAVISION exisitiu desde el 1964 hasta el 2004; RTVC del 2004 a la actualidad". Também descreve "los distintos cambios que tuvo el canal educativo-cultural, se llamaba

\footnotetext{
${ }^{107}$ Disppnível em: $<$ http://www.antv.gov.co/index.php/la-antv/asuntos-concensionales $>$. Acesso em 12 abr. 2017

${ }^{108}$ FONTV - Fondo para el Desarrollo de la Televisión.
} 
primero Canal 11; Canal 3; en el 1995, Señal Colombia; de 2001 al 2005, La Señal”. (BENAVIDES, texto apresentação e informação verbal)

Por sugestão de Patricia Castaño e Adelaida Trujillo, conversei em Bogotá com Alexandra Falla Zerrate ${ }^{109}$, diretora da Fundación Patrimonio Filmico ${ }^{110}$, e que integrou as duas organizações, CNTV e ANTV. Ao perguntar a Alexandra Falla como operavam as duas entidades, qual era sua visão e que caminhos possíveis pensava para a televisão pública, respondeu:

Tuve la oportunidad de trabajar como asesora en la Comisión Nacional de TV, luego como miembro de la junta directiva en la Autoridad Nacional de Televisión y de ser directora operativa de um canal regional de Bogotá, que es uno de los más grandes (Canal Capital), y tuve la oportunidade de trabajar en el Operador Público, que en ese momento no era RTVC sino Inravisión (antes del 2004) y fui Directora de la Radio Nacional en Inravisión, que es la radio pública. Basicamente, yo diría que la televisión pública en América Latina en general tiene el mismo reto que es poder superar los temas puramente políticos y gubernamentales para realmente generar una parrilla de programación que responda a las necesidades, expectativas y funciones que deben cumplir la televisión pública en términos de construcción de ciudadania, en términos de fortalecimiento de la identidad, en términos de cohesión social y el gran reto siempre es poder desligar eso de los gobiernos de turno. Y tanto la pública nacional como la pública regional siempre se ven afectadas por las decisiones políticas. Es decir, tú puedes tener um alcalde, como en el caso de Bogotá, que decida darle muchos recursos al canal y puedes tener otro alcalde que decida no darle muchos recursos y priorizar de otra manera. (Grifo nosso)

Naquele momento, novembro de 2015, Alexandra Falla relatou que os recursos que a Autoridad Nacional de Televisión dava em média aos canais regionais girava entre 7 e 8 mil milhões de pesos colombianos por ano (aproximadamente 2.350.000 e 2.700.000 dólares). No entanto, destacou que dependendo dos "departamentos" (estados) ou regiões, esse dinheiro do estado para a televisão pública pode variar, em maior ou menor medida. "Por ejemplo, mientras que para el TRO - canal regional del Oriente - la plata que le da la ANTV es el 80\% de su presupuesto, altísimo, en el caso de Teleantioquia o del Canal Capital, que son grandes, la plata que le da la ANTV es el $40 \%$ de su presupuesto". Perguntei sobre como era decidido esse percentual e a resposta:

\footnotetext{
${ }^{109}$ Encontro em 23 nov. 2015.

110 Fundación Patrimonio Filmico <http://www.patrimoniofilmico.org.co/index.php/documentos-ypublicaciones/documentos/198-alexandra-falla-zerrate $>$.
} 
La ANTV decide cuánto le da a cada regional, pero cada municipalidad, cada departamento decide también cuanto le da a su canal. Entonces, obviamente si el alcalde de Bogotá le da mucha plata pues lo que le da la ANTV es poquito. Si le da poquito, eso se vuelve mucho. Si no le da nada, eso es todo. Y así pasa. Por ejemplo, en San Andrés, la plata que le da ANTV es casi que toda la plata del canal. Entonces mientras algunos viven con 7 mil millones al año, otros viven con 25 , otros viven con 30 mil. Entonces es muy desigual la plata con la que cuenta cada canal regional. Y tiene que ver, claro, con la solidez financiera de los departamentos: no todos tienen plata para invertirle de manera tan importante en la televisión. O no todos políticamente ven que es estratégico meterle tanta plata en un canal de televisión. $\mathrm{Y}$ ese es otro tema. Es una decisión puramente política: cuánto le doy yo al canal de la ciudad? Si me interesa, si no me interesa. Entonces obviamente, yo lo que creo es que la regulación y la normativa tendrían que, de alguna manera, tratar de bajar mucho el efecto que tiene las decisiones políticas en los canales regionales. Porque puede suceder eso, que yo vengo de una muy buena parrilla de programación que está teniendo êxito y llega un gobierno nuevo y dice "a mí esta apuesta no me interesa". Y la cambia completamente. Y eso pasa. (Informação verbal)

Consultei Diana Díaz Soto por email sobre o montante de recursos que a ANTV repassava à Señal, quando ela já dirigia a Señal Colombia. Recebi sua resposta em 28 de novembro de 2016, conforme transcrevo: "Con respecto al presupuesto, la ANTV asigna a Señal Colombia un total aproximado de 18 mil millones de pesos, que vienen siendo $\underline{6}$ millones de dólares que está destinado para producción, programación y promoción a través de autopromos y entornos digitales" (DIAZ, Diana, 2016, via email). No encontro com Marcela Benavides perguntei se a ANTV repassava recursos também para a Señal Institucional e o volume distribuído:

Señal Colombia es la que tiene mayor presupuesto para producción pero es que los modelos son distintos, porque Institucional tiene un modelo de operación diferente. A ellos no les dan presupuesto como el que viene de la ANTV, sino que ellos venden servicios a las entidades del estado. Ellos producen plata. (Informação verbal)

Em relação às mudanças que teriam ocorrido com a substituição da CNTV pela ANTV, segundo Alexandra Falla, não havia alterado o número de membros da comissão. Mudou a origem da entidade "que me parece que no fue un buen avance porque la Comisión Nacional de Televisión era un organismo de carácter constitucional y en ese sentido tenía mucho más autonomía y ahora es del gobierno" (Informação verval). Perguntei se a CNTV era "constitucional" como era classificada a ANTV e respondeu que era "legal". Questionei a diferença entre as duas ordenações jurídicas - legal e constitucional - e Alexandra foi didática na resposta: "La diferencia es que tú no podías desaparecer de un brochado a la CNTV porque 
para hacer una reforma constitucional se requieren dos pasos en el Congreso. En cambio, para hacer una reforma legal si yo quisiera desaparecer la ANTV hago una reforma en la ley y se fue, chao (sic)."

Alexandra Falla passou por todas essas instituições e como ela mesma se apresenta, “tengo la mirada desde todas las orillas". Passou pela CNTV, "a mí me tocó la formación de la CNTV del 1996 al 1999 casi al 2000, pasé por todas las discusiones, y luego estuve en la Autoridad del 2012 al 2015, también estuve en Inravisión y en un canal regional”. No Canal Capital esteve de 2003 a 2006; e no Inravisión de 2000 a 2003. E não acha que foi bem resolvida a forma escolhida para a RTVC:

Cuando yo estuve en Inravisión me tocó la liquidación de Inravisión, yo salí y los 3 o 4 meses liquidaron Inravisión. Para mi gusto no quedó bien armado esto de RTVC. No he entendido eso de contratar y contratar gente. No es subdirección técnica. No hay una cabeza que sea de un ingeniero que se encargue de los temas por ejemplo. Lo que es un poco loco.

Nos encontros em Bogotá foi possível resgatar (na perspectiva de protagonistas e articuladores do movimento em defesa da televisão pública colombiana) os momentos que antecederam a extinção do Inravisión e surgimento da $R T V C$.

\subsection{Televisão pública de qualidade - os antecedentes}

Paralelamente às ações do governo, ainda na década de 1990, especialistas, produtores e acadêmicos colombianos promoveram atividades para reflexões que mobilizaram o Ministério da Cultura. Estavam envolvidos, entre outros especialistas, o professor e crítico de televisão Omar Rincón, que elaborou com outros dois professores, Jesús Martin Barbero e German Rey, o documento Televisión pública, cultural de calidad. Este estudo foi encomendado pelo Ministério da Cultura, como relatou a ex-gerente da Señal Colombia Marcela Benavides ${ }^{111}$. Foi nesse momento, em 2000, que o Ministerio de Cultura (MinCultura) ingressou nas discussões por uma televisão de qualidade com mais intensidade.

\footnotetext{
${ }^{111}$ Encontro em Bogotá, em 19 nov. 2015. Perfil recebido de Marcela Benavides: cuenta con 18 años de experiencia en televisión cultural, siendo productora ejecutiva y creativa de seriados y unitarios, así como de proyectos convergentes de carácter infantil, cultural y educativo. Como coordinadora de Señal Colombia orientó, lideró y administró estrategias de contenidos, producción, programación, financiación y distribución del canal en todas las plataformas. También diseñó e implementó el Mercado de Coproducción, estrategia internacional de
} 
Recebi de Marcela Benavides, entre os vários documentos, o Marco Legal-Políticas Culturales, elaborado pelo MinCultura, que reunia um plano de desenvolvimento para vigorar entre 2001 e 2010, com o propósito de formular, coordenar, executar e vigiar a política de Estado em matéria cultural, recreativa e de aproveitamento do tempo livre. A televisão ocupava um espaço de destaque neste documento.

Marcela Benavides relatou as iniciativas empreendidas no final dos anos 1990 com o objetivo de sanar as "deficiências contemporâneas" da televisão pública a partir da reestruturação da Señal Colombia. Para iniciar o processo, em 1998, a Junta Administradora do Inravisión decidiu apoiar a iniciativa apresentada pela direção do Instituto de empreender um processo participativo para a concepção de uma estratégia nacional de melhoria e de uso apropriado dos meios de comunicação em benefício da educação e da cultura.

O documento Marco Legal-Políticas Culturales descreve os antecedentes que ajudam a compreender a participação do MinCultura na televisão pública:

La participación del Ministerio de Cultura - y antes la de Colcultura ${ }^{112}$ - en el canal educativo cultural no ha sido igual a lo largo de la historia. Cuando Inravisión era el responsable de programar Señal Colombia, entregaba espacios y horarios a varios productores e instituciones. Bajo ese modelo, Inravisión asignó al Ministerio de Cultura espacios en distintos momentos ${ }^{113}$.

Ou seja, o que o Inravision fazia era dividir a grade e entregar espaços pelo período de um ano às universidades, a programadoras independentes, além de diferentes instituções do governo (saúde, educação, ciência, etc). Estavam na programação também as transmissões ao vivo do Congreso da República. Dessa forma, entre 1998 e 2000, com recursos do Fondo

cofinanciación de contenidos. Actualmente orienta la construcción del Plan Nacional para las Artes 2015-2020 del Ministerio de Cultura y es consultora de La Lupita Producciones: para el diseño de canales públicos culturales de Perú y Chile.

${ }^{112}$ O Instituto Colombiano de Cultura (Colcultura) foi criado em 1968, durante o governo de Carlos Lleras Restrepo. Funcionava como um organismo descentralizado no âmbito do Ministério da Educação Nacional. No governo de Eernesto Samper, a Ley General de la Cultura, aprovada em 7 de agosto de 1997, liquida o Colcultura e cria o Ministerio de Cultura. Este assumiu as funções do Colcultura e mais cinematografica, etnocultura e juventude. Cf. Instituto $<$ https://es.wikipedia.org/wiki/Ministerio de Cultura de Colombia $>$. Acesso em 5 jan. 2017.

${ }^{113}$ Ministerio de Cultura, República de Colombia. 1. Marco Legal-Políticas Culturales. Antecedentes para compreender la participación del Ministerio de Cultura en la televisión pública. La Franja. 
para el Desarrollo de la Televisión y los contenidos (FONTV - CNTV ${ }^{114}$ ), o Ministério da Cultura participou com 22 horas de programação semanal na Señal.

\begin{abstract}
"Este espacio denominado La Franja fue el momento más destacado de la televisión cultural en el canal público porque el Ministerio logró convocar al mejor recurso humano en la producción y orientar un proyecto coherente y de excelente calidad en el mejor horario de la televisión" (BENAVIDES, Informação verbal).
\end{abstract}

Começava ali a contribuição do Ministério da Cultura para o fortalecimento da Señal Colombia como um canal de serviço público, espaço de expressão da identidade e diversidade, o que facilitou a promoção e a difusão da criatividade dos colombianos, como contou Benavides. As descontinuidades que nasceram com a televisão se repetiriam mais uma vez. A faixa da programação que vinha sendo dedicada ao Ministério da Cultura foi descontinuada, em decorrência de mudanças políticas do Inravisisón. Na licitação pública realizada em 2000, o MinCultura fícou com um único espaço, denominado Diálogos de la Nación. Tratava-se de uma série que apresentava os olhares de vários documentaristas nacionais que percorriam o país para apresentar as realidades das diferentes regiões (o local e o regional), e assim configurar um mapa do que era ser colombiano, e que herança coletiva deveria ser reconhecida.

Foi considerado um projeto ambicioso e de formação para a maioria dos documentaristas que assumiram pela primeira vez o desafio de realizar um documentário de 52 minutos, quando o comum na época eram 26 minutos. Segundo Marcela, para muitos realizadores esse momento se constituiu em uma experiência educativa, requisitos para se alcançar distribuição internacional.

Entre as iniciativas de defesa da televisão de qualidade enumeradas pela ex-dirigente da Señal estavam as conferências e encontros organizados pelas diretoras da Citurna Producciones en Cine y Video e Fundación Imaginario, Patricia Castaño e Adelaida Trujillo.

\footnotetext{
${ }^{114}$ Criado pela Ley 182 de 1995, durante a vigência da CNTV - Comissión Nacional de Televisión. A CNTV é substituida pela ANTV -Associación Nacional de Televisión, conforme a Ley 1507/2012, e o fundo altera o nome, como artigo 16 informa: Creación y objeto del fondo para el desarrollo de la televisión y los contenidos. Créase el Fondo para el Desarrollo de la Televisión y los Contenidos como una cuenta especial a cargo de la ANTV. El objeto del Fondo es el fortalecimiento de los operadores públicos del servicio de televisión, la financiación de programación educativa y cultural a cargo del Estado y el apoyo a los contenidos de televisión de interés público desarrollado por operadores sin ánimo de lucro además de financiar el funcionamiento de la ANTV. Disponível em: <http://www.alcaldiabogota.gov.co/sisjur/normas/Norma1.jsp?i=45327>. Acesso 14 fev. 2016.
} 
"Adelaida y Patricia firmaron un acuerdo por la televisión pública de calidad y ellas empezaron a traer conferencistas de todas las partes del mundo y los canales públicos y regionales siempre participaron”, lembrou Marcela.

No encontro com Adelaida Trujillo, em Bogotá, recebi generosamente documentos diversos, entre esses, uma cronologia dos 25 anos de realizações da Citurna. Ali encontrei a descrição do que foi o encontro realizado no ano $2000^{115}$. "Uno de los compromissos de Citurna ha sido la generación de debate y diálogo sobre el papel de los medios en general y la televisión en particular, en la construcción de lo público y en el desarrollo de los países latinoamericanos". Entre esses compromissos, Trujillo destacou o encontro - TV de Calidad pública + infantil + juvenil - que contou com o apoio de instituições como UNICEF Colombia, Goethe Institut, a Comisión Nacional de Televisión, Pontificia Universidad Javeriana, Ministerio de Cultura, Canal Capital e Corporación del Nuevo Cine Latinoamericano, entre outros. Durante uma semana Bogotá reuniu realizadores de diversas partes do mundo para debater linguagens, formatos e apresentar os tipos de programações de diferentes canais e países, em eventos paralelos como Mini-INPUT Bogotá ${ }^{116}$, Prix Jeunesse en Bogota ${ }^{117}$ e Muestra y Conferência Internacional. A programação deste encontro foi intensa como atesta o catálogo de mais de 100 páginas que recebi de Adelaida Trujillo.

Foi um momento importante para intensificar o debate no século 21 por uma nova televisão pública no país, que culminaria com a criação da RTVC em 2004. Foram diversas conferências com participação de convidados e "experts" de vários continentes, entre eles, do Brasil, Beth Carmona (ex-TV Cultura e naquele momento Discovery Kids para Iberoamerica) e Tereza Otondo (TV Cultura).

Como desdobramento desses encontros foi firmado o Compromiso Nacional de Televisión de Calidad para la Infancia en Colombia, "um acordo de vontades, produto do diálogo e negociação entre instituições públicas, canais públicos e privados, academia, anunciantes, empresas do setor privado, ONGs, associações de pais e educadores, entre outros atores envolvidos com a televisão, a infância e o seu desenvolvimento" (TRUJILLO,

\footnotetext{
${ }^{115}$ O encontro aconteceu entre os dias 13 e 19 de setembro de 2000, em Bogotá.

${ }^{116}$ O INPUT - International Public Televisión (como referido anteriormente) reúne produtores e canais de todo o mundo que trabalham pelo desenvolvimento de uma televisão pública de qualidade. Os Mini-INPUT é uma versão da Mostra e Conferência Internacional concebida para um país ou uma região.

${ }^{117}$ O Festival Prix Jeunesse é realizado a cada dois anos em Munique (Alemanha). As maletas Prix Jeunesse reúnem as melhores produções apresentadas nos festivais e, no encontro em Bogotá, foram apresentadas produções - infantis e juvenis - de ficção e não fição, para faixas distintas (12-15 anos e 7-11 anos) (CATÁLOGO Muestra y Conferência Internacional. Citurna Producciones. Bogotá, 2000).
} 
informação verbal e documentos). A assinatura desse "compromisso" no dia 30 de agosto de 2005, por um grupo de 28 organizações às quais se somariam mais duas dezenas posteriormente, se configurou como um marco do evento Televisión de Calidad 2005.

Para Marcela Benavides esses encontros foram fundamentais para preparar profissionais, especialistas e defensores da televisão pública. Ela cita entre as pessoas que participaram desses eventos, a então diretora de Comunicações do Ministério da Cultura, Guiomar Acevedo, com quem trabalhou naquele período.

Guiomar había asistido a todos los talleres, ella conocíó a Beth (Carmona), conoció también el trabajo que hizo en TV Cultura, fue un compromiso con televisión de calidad.

E Guiomar Acevedo inspirada em experiências de diversos países que chegavam, entre eles, Brasil, propôs": 'tenemos que hacer un diseño de TV de calidad". Para isso, defendeu que a televisão de qualidade teria que ter a participação da audiência. Distribuiu à equipe documentos diversos, entre eles, manuais da BBC para que todos lessem. Daí caminharam para organizar o trabalho. O canal Señal decidiu implementar a figura do produtor delegado, para acompanhar a programação que começava a ser terceirizada: “empezamos la construcción de herramientas de seguimiento que fue el manual general de producción que tiene cuales son lineamientos para que los contratistas externos produzcan los contenidos y también empezamos a hacer el diseño de las convocatorias" (BENAVIDES, Informação verbal.)

\subsection{Momentos derradeiros do Inravisión}

Em 1998, a Junta Administradora do Inravisión decidiu apoiar a iniciativa da direção do Instituto de empreender um processo participativo para desenhar uma estratégia nacional com o objetivo de intensificar o uso dos meios de comunicação em benefício da educação e da cultura. Foram se agregando outros ministérios e instituições. Sob a coordenação dos Ministérios - da Comunicação, Educação e Cultura -, mais de 120 organizações, públicas e privadas, e especialistas independentes participaram durante 16 meses de um intenso processo de consulta, discussão e consenso para estabelecer no país uma estratégia abrangente denominada Proyecto Nacional de Educación y Cultura a través de los Medios Masivos de Comunicación - PROCEM. Este projeto continha cinco princípios norteadores: "Movilización social; Reconocimiento de la diversidad cultural y ambiental; Respeto por el conocimiento y 
la experiencia; Transversalidad y estabilidad; Permanencia de los programas." Com essa complexidade, foram criados grupos de especialistas nas áreas de Educacão infantil; Educação básica; Educação superior; Valores humanos; Saúde, Meio ambiente, Ciência e Tecnologia; Cultura e Formação física, Etnias, Comunicação comunitária, Prevenção de desastres, Respeito pela diferença e equiparação de oportunidades, Idoso, Alfabetização audiovisual, Capacitação e educação para o trabalho, Rádio, Centro de serviços, Programação e definição da producão. Segundo Benavides, as definições resultantes desse movimento previam uma televisão pública, educativa e cultural de qualidade, mas o Instituto Nacional de Rádio y Televisión -Inravisión - não teve êxito em sua implantação. (Grifo nosso)

Em 2004, no governo do liberal Álvaro Uribe Vélez (2002-2010), aconteceu a grande virada: Inravisión foi liquidado. Também foi liquidada a produtora Audiovisuales. Uma comissão intersetorial assessorou a liquidação do Inravisión, "en crisis por un alto passivo pensional" (BENAVIDES, informação verbal), dando lugar à Radio Televisión Nacional de Colombia - RTVC ${ }^{118}$, que hoje congrega a Señal Colombia, Señal Institucional, Rádio Nacional de Colombia, Radiónica e Señal Memória.

A liquidação resultou na redução do quadro. O número de contratados que chegava a 600, foi reduzido a 70 cargos (todos administrativos e jurídicos). Criaram um modelo de terceirização para a totalidade da programação da Señal Colombia. Essas informações também foram relatadas por Diana Diaz Soto, atual coordenadora da Señal, que acompanhou todo o processo de mudanças do canal. Segundo Benavides, foi feito um redesenho - a Señal se dividiu em dois canais: Señal Colombia - educativo e cultural, e Señal Institucional, para transmissões do Congresso e produção de conteúdos das instituições do Estado. Essa divisão foi positiva, na opinão da ex-dirigente: “a Señal era um canal 'Frankenstein', com faixas dedicadas ao público infantil, transmissões das sessões do Congresso, do Ministério da Defesa, e de todos os outros". Concorda com essa posição o professor Omar Rincón, que também considerou positiva a separação para preservar a autonomia e independência do canal que se apresenta como público, ou seja, a serviço da sociedade e não do governo.

\footnotetext{
${ }^{118}$ O Diário Oficial 45.743, de 24/11/2004, publica o Decreto 3912 de 2004, pelo qual era aprovada a estrutura da Sociedad Radio Televisión Nacional de Colombia, RTVC. Esse decreto determinava as funções e dependências. Disponível em: $<$ http://rtvc-assets-qa-

sistemasenalcolombia.gov.co.s3.amazonaws.com/archivos/decreto 3912 de 2004.pdf>. Acesso em 5 abr. 2017.
} 
Conversei em Bogotá com Tatiana Duplat (em 23 de novembro de 2011), diretora do Proyecto Señal Memória de RTVC. Também ela destacou a separação dos canais como um diferencial na América Latina:

\begin{abstract}
Es un modelo que llama mucho la atención en América Latina, porque aquí se ha diferenciado, se ha separado la televisión educativa y cultural de la TV institucional. Y aunque las dos funcionan en el marco democrático, el quitarle el lenguaje institucional a la tv educativa y cultural, las hacen con más posibilidades, más rica, pueden expresar más cosas, pueden decir...y es vista desde la audiencia con menos prevención. Y todo lo institucional - la voz del estado - va por el canal institucional, se distribuyen por franjas, por espacios, distintas instituciones y además siempre tienen prioridad nichos de interés de la sociedad como el presidente que va a hablar o cosas así. Y ese canal institucional no tiene noticieros. Se le quitó la opción de dar noticias, lo que hace es informar desde distintas perspectivas lo que hace el Estado colombiano. Y Señal Colombia, que es lo que tú conoces, que está dedicada desde el 2004 exclusivamente a la TV educativa y cultural.
\end{abstract}

Nessa nova reestruturação, a "Junta diretiva"- representada pelos ministérios da Educação, Cultura e Tecnologias da Informação e Comunicações -, criou mesas de trabalho para desenhar os conteúdos, definir o modelo de produção e de terceirização, formato dos contratos e das convocatórias. "O que se fez nesse momento foi dividir salomonicamente a grade: pela manhã, de $8 \mathrm{~h}$ às 17h, Educação; de 17h às 23h, Cultura" (Benavides). A Direção de Comunicações do Ministério da Cultura se encarregou do fortalecimento dos meios públicos como espaços de criação e dinamização dos processos culturais participativos e includentes.

O decreto 3912/2004, assinado pelo presidente Álvaro Uribe Vélez, definiu a Radio Televisión Nacional de Colombia, RTVC: "una sociedad entre entidades públicas, indirecta, del orden nacional sometida al régimen de las Empresas Industriales y Comerciales del Estado". Pelo decreto, e de acordo com os estatutos internos da RTVC, era função da Junta Diretiva submeter ao Governo Nacional a estrutura interna da entidade:

1. Junta de Socios

2. Junta Directiva

3. Gerencia General

3.1 Oficina Asesora de Jurídica

4. Subgerencia de Televisión

5. Subgerencia de Radio

6. Subgerencia de Soporte Corporativo

7. Organos de Asesoría y Coordinación

7.1 Comité de Coordinación del Sistema de Control Interno

7.2 Comisión de personal 
O organograma da RTVC apresenta a seguinte estrutura conforme Decreto 3912 de 2004:

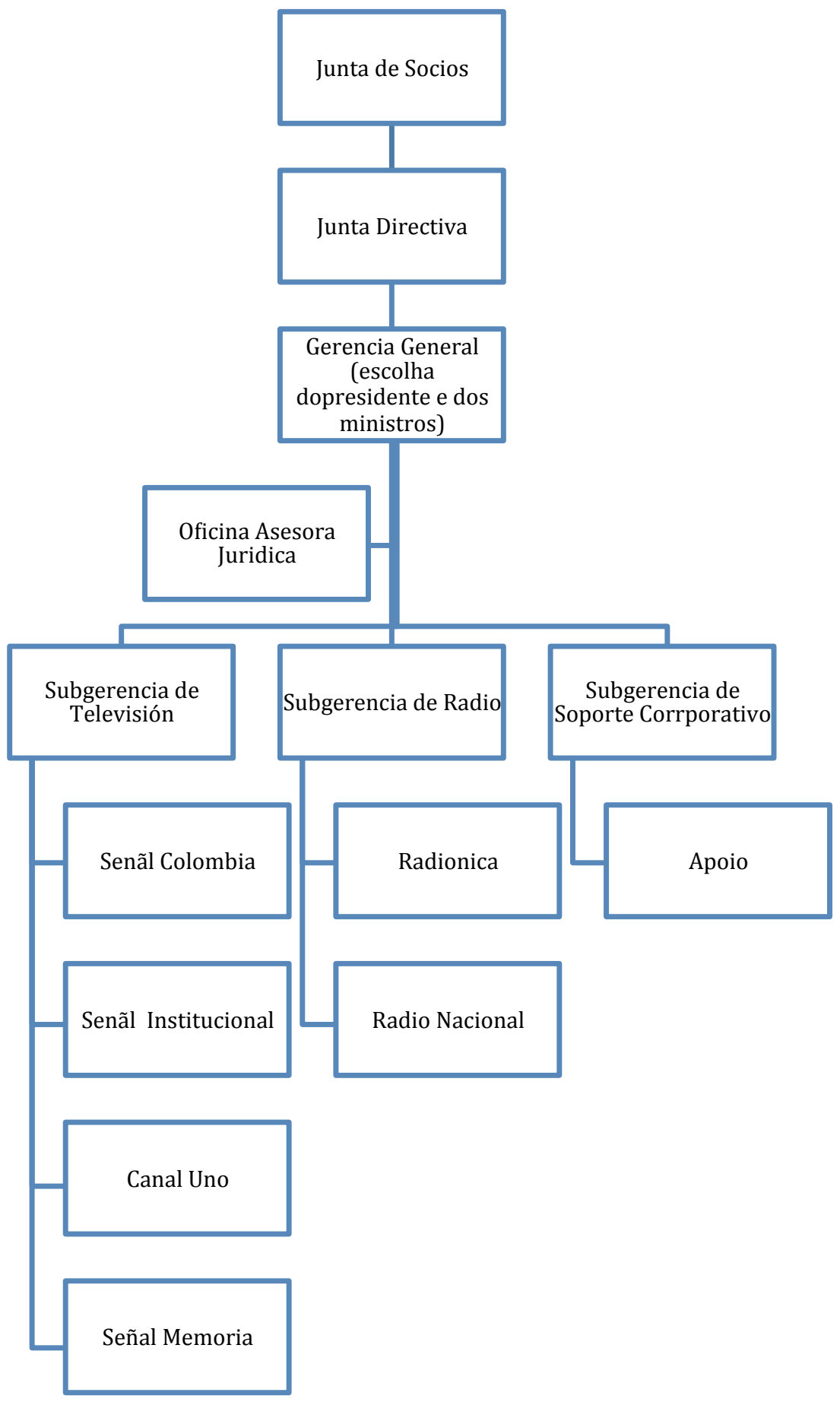

Os cargos para Gerência Geral, Subgerencia de Televisón, Subgerencia de Radio e Subgerencia de Soporte Corporativo são indicações do governo, como já informado. 


\subsection{Televisão colombiana - livre concorrência?}

Para Paula Arenas ${ }^{119}$, a Colômbia com regulamentos avançados, combate por princípio as práticas monopolísticas, preservando o direito fundamental de informar e ser informado $^{120}$. Arenas traça um panorama da televisão pública colombiana: dois canais nacionais, um canal nacional de operação mista, oito canais regionais e um canal local, além de canais comunitários. O colombianos contam ainda com cerca de 90 canais internacionais, de assinatura por cabo ou satélite. O monopólio está do outro lado, na opinião da assessora da RTVC: "la oferta de los privados está formada por dos canales nacionales y un canal local". Segundo Arenas, apesar desta ampla oferta, a Colômbia vive um fenômeno singular, dois canais privados - Caracol e RCN - se configuram "las voces predominantes de la televisón". Ela lembra que o último grande debate sobre um terceiro canal foi tão 'feroz' que deu a estocada final para acabar com a "célebre Comissión Nacional de Televisón (CNTV) que cerró sus puertas en el 2011". Para substituí-la, como já citado, foi criada, em 2012, a Autoridad Nacional de Televisión ( $\mathrm{ANTV}^{121}$ ). Assim, surge uma outra causa, apontada por Paula Arenas, a luta para o fim da CNTV e o surgimento da ANTV.

Em seu artigo Paula Arenas discorre sobre o entendimento dos Ministérios em relação ao "potencial narrativo da televisão". Para ela, o que melhor entendeu o papel da televisão pública foi o Ministério da Cultura:

allí la perciben como un aliado y recurren a ella como parte de su estratégia de divulgación y sensibilización; cuando se trata de rendir cuentas a la ciudadania, acuden a Señal Institucional; por el contrario, si se trata de sensibilizar a la ciudadania acerca de prácticas o expresiones culturales, recurren al canal educativo y cultural, para ello emplean formatos como las séries documentales.

\footnotetext{
${ }^{119}$ ARENAS, Paula. El futuro de la televisión pública educative y cultural. El caso Señal Colombia. In Boletim Cultural y Bibliografico, Número 87. Biblioteca Luis Ángel Arango, Bogotá, 2015.

${ }^{120}$ No entanto, é importante destacar que a Señal Colombia não possui espaço para o jornalismo, como será abordado adiante.

${ }^{121}$ AUTORIDAD NACIONAL DE TELEVISIÓN - ANTV, la Agencia Nacional Estatal de Colombia, creada mediante la Ley 1507 de 2012, que tiene por objeto: Brindar las herramientas para la ejecución de los planes y programas de la prestación del servicio público de televisión, con el fin de velar por el acceso a la televisión, garantizar el pluralismo informativo, la competencia y la eficiencia del servicio (...).La ANTV está conformada por una Junta Nacional de Televisión, con cinco membros, no reelegibles, un director y cuenta con el apoyo financiero del Fondo para el Desarollo de la Televisión (Fontv). In: < http://www.antv.gov.co/la-antv/quienessomos>.
} 
Tanto a Señal como o Ministério da Cultura, de acordo com Paula Arenas (2015), reconhecem os critérios de diversidade como eixo temático. "Ambos entendem e promovem a televisão como uma experiência cultural”. A Señal produziu, em conjunto com o Ministério da Cultura, várias séries. A primeira, em 2004, sobre arte que se chamava Plástica-Arte contemporáneo en Colombia, uma série de 10 capítulos com 30 minutos de duração. Desde então, vêm produzindo uma série por ano, sobre temas diversos. Segundo Arenas, o Ministério da Educação tem posição diferente: defende a televisão de circuito fechado para aulas dirigidas a professores e alunos e planeja ter um canal com essas características. Enquanto isso, "colabora com a Señal Colombia en el desarrollo de contenidos dirigidos al público infantil" (ARENAS, 2015) ${ }^{122}$.

Paula Arenas considera um dos "grandes inventos" das mudanças o financiameno vindo dos recursos do FONTV, entre toda a improvisação que resultou na criação da ANTV, RTVC e companhia. Ela se refere à forma encontrada pelo Estado em uma "normatividad de conyuntura": $1,5 \%$ das vendas brutas dos canais privados de televisão aberta alimenta o Fondo para el Desarrollo de la Televisión y los contenidos (FONTV) ${ }^{123}$, e os operadores de televisão por assinatura satélite ou cabo, “aportan cada mes poco más de $\$ 1.800$ por subscritor" (aproximadamente US\$ 0,6). Essa é uma das razões para a torcida por um terceiro canal, que significaria um acréscimo de recursos ao Fundo (Cf. ARENAS). Os recursos do FONTV são geridos pela ANTC e distribuídos às televisões públicas pela RTVC. Os percentuais direcionados aos canais variam de acordo com as necessidades, como narra Alexandra Falla.

No entanto, isso também está sujeito à "boa vontade econômica" dos canais privados e

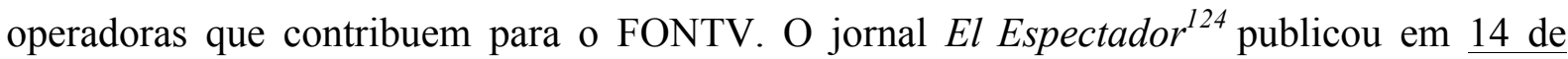
fevereiro de 2016, extensa entrevista realizada pelo jornalista Edwin Bohórquez Aya, com a

\footnotetext{
${ }^{122}$ No Brasil, o Ministério da Educação mantém a TV Escola, que foi produzida, mediante contrato, pela Associação de Comunicação Educativa Roquette-Pinto, mantenedora da então TVE Brasil.

123 No Brasil, existe a Contribuição para o Fomento da Radiodifusão Pública (CFRP), criada pela Lei da EBC, que retira um percentual do Fundo de Fiscalização das Telecomunicações (Fistel) para financiar a EBC e a radiodifusão pública em geral. Do total arrecadado, $75 \%$ são destinados à $\mathrm{EBC} ; 2,5 \%$ à Anatel, pela administração; e $22,5 \%$ para as demais emissoras do campo público. A taxa foi criada para garantir a independência financeira da $\mathrm{EBC}$, mas a estatal recebe apenas parte dos recursos em função de questionamentos judiciais liderados pelo SindiTelebrasil (Sindicato das Teles).

Disponível em: http://teletela.com.br/teletime/03/04/2017/ebc-defende-divisao-da-taxa-de-radiodifusao-publicaapos-tema-ser-pacificado-na-justica/?noticiario=TL Acesso em 10 Mai. 2017.
}

124 Disponível em <http://www.elespectador.com/noticias/economia/esta-riesgo-tv-publica-articulo-616377>. Acessado em 14 fev. 2016 
vice-presidente da Directv na Colômbia, Natalia Iregui. Transcrevo parte da abertura da matéria, que resume o alerta que faz a executiva e que inspirou a manchete: Por que está em risco a TV Pública?

Natalia Iregui, vicepresidente legal y de relaciones institucionales de Directv Colombia, habla sin pelos en la lengua de lo que ella considera un problema grave para la televisión pública, financiada en un $75 \%$ por los operadores de televisión cerrada. Las causas: la libertad que tienen aplicaciones como Netflix y el elevado desvío de recursos en los canales comunitarios. ¿Qué podría pasar si el Gobierno no genera una política pública actual dirigida al sector?

Segundo a executiva, a tecnologia avança mais rápido dos que as normas e o mercado, mas um tema hoje que causa dor de cabeça aos operadores é o "desequilibrio competitivo que puede existir con los operadores como Netflix”. Iregui traçou um panorama da situação atual, citando alguns números para mostrar o crescimento deste operador que está chegando forte ao mercado colombiano. Na Colombia, afirma, ele já já tem 600 mil usuários. São maiores que Telefónica, enquanto a Directv tem 1.200.000, a Claro, que é a maior, tem 2.200.000 e, nessa divisão do tabuleiro, o Netflix não paga um só imposto, afirma Iregui ao acrescentar:

nosotros pagamos un dolar por usuario por mes al Gobierno por prestar el servicio, y esa es la plata que va para la televisión pública. Netflix, en tres años, tuvo el mismo crecimiento de Directv en todo Latinoamérica, y se espera que en 2018 Netflix sea el operador más grande de televisión por suscripción en la región.

Questionada sobre o impacto disso para a Televisão pública, Iregui lembrou que a TV pública conta com duas fontes de financiamento, os canais RCN e Caracol, que representam mais ou menos $25 \%$ do financiamento, e os operadores de televisão por assinatura, pagam ao redor dos $75 \%$ restantes. Os operadores gestionam junto ao Ministério das Comunicações para terem a mesma liberdade que a Netflix, ou para que os que chegam com novas tecnologias de acesso livre tenham as mesmas responsabilidades fiscais. Esses dados referemse ao ano de 2016. 


\subsection{Traçando os caminhos para a produção de conteúdos}

A participação do Ministério da Cultura na definiç̧ão dos conteúdos da Señal em seu início foi fundamental para traçar as linhas gerais e as condições para a produção de conteúdo. Segundo Benavides, foi a partir do MinCultura que se estabeleceram os critérios mínimos para o desenvolvimento da produção realizada por terceiros, "exigiendo que hubiera un desarrollo de investigación más profundo en donde estuvieran justificados los temas, los enfoques, los personajes, donde estuviera también planteada una consistência entre el tratamiento audiovisual y la audiência a la que estaba dirigido.” Bem diferente de como era antes, quando "la gente" recebia os contratos e fazia o programa conforme o gosto do diretor e não pensando em todos esses aspectos descritos (BENAVIDES, Marcela, Informação verbal).

Esse trabalho oriundo do Ministério da Cultura gerou a primeira versão de como fazer uma "convocatória ${ }^{125}$ en donde cada ficha tenía cual era el objetivo temático, cual era el objetivo para las audiências y que tipo de narrativas estavam buscando". E mais, dava os passos de "como se evalúa, quienes son los jurados que puden evaluarla, como se producen los contenidos; y como se hace el seguimento de esos contenidos, como se hace la evaluación”. E assim começaram as convocatórias que foram se aprofundando e resistem até hoje.

Os produtores foram sendo preparados para trabalhar para Señal. Como relata a exdirigente Marcela Benavides, estavam realizando algo dirigido a um canal com políticas editoriais, para cada faixa de audiência e que precisava ser consistente. Esse processo, lembra Marcela, levou alguns anos para concluir toda a transição. Segundo ela, foi muito planejamento, ensaio e erro, além de ter tido muitas interrupções, com as mudanças de direções frequentes,

Lo que ha sobrevivido a los años un poco es la metodología y aunque a veces la han querido tumbar porque es importante señalar que, también esa metodología, además de pensar en la televisión de calidad, rompió con un tema político y es que algunos directores anteriores contrataban con criterios de cercanía a sus amigos, contrataban gente de la vieja guardia, que no necesariamente es malo, pero en este caso mucha de esa gente llevaba

\footnotetext{
${ }^{125}$ Espécie de licitação ou concurso no Brasil. Aqui, licitação é o conjunto de procedimentos administrativos (administrativos porque parte da administração pública) para as compras ou serviços contratados pelos governos Federal, Estadual ou Municipal. A TV Brasil/EBC já realizou concursos, ou pitichng, como nomeou, para seleção de projetos de produtores independentes.
} 
haciendo televisión 30 años y no estaba interesada en aprender nuevas miradas, nuevas narrativas y entonces eso también generó como una limpieza de qué tipo de gente se presentaba y empezó a entrar gente joven, empezó a entrar gente muy joven, salida de las universidades, independiente, que estaba con sus propias ideas y, pues, eso fue muy bueno porque renovó el canal. (BENAVIDES, Informação verbal)

Nesses primeiros anos, conforme relatos das protagonistas Marcela Benavides e Diana Díaz Soto, que trabalharam na fase inicial da Señal como produtoras delegadas, começou a tomar forma toda a base conceitual. "Fue un trabajo muy árduo y difícil para convencer al sector audiovisual entrar en esas dinâmicas porque no estaban acostumbrados y no querian que el canal interviniera en suas creaciones". Foi preciso convencê-los de que não era um prêmio por participação em concurso ou a um fundo de investimento cultural, mas que estavam fazendo algo para um canal com suas políticas editoriais.

Antes de ingressar na Señal Colombia como produtora delegada em 2007, Marcela trabalhou no Ministerio de Cultura (2004 e 2006) assessorando a direção de artes nas definições da programação da Señal. Nesse período, também teve papel de destaque como diretor de Comunicação do MinCultura, Germán Franco ${ }^{126}$, responsável pela implantação de políticas públicas para a televisão. Benavides considera como marco importante o período de 2005 a 2007, quando a produção de conteúdos conseguiu romper "um pouco" a visão que os telespectadores tinham da televisão pública.

Porque, claro, demoró siempre unos dos años en empezar a verse al aire lo que se estaba proponiendo hacer y romper con lo que se venía viendo antes que era un canal que tenía mezcladas cosas institucionales con cosas educativas-culturales y de niños, pues todo esto que te conté. Y cuando empezaron a ver una parrilla un poco más organizada y con unos contenidos diarios frescos y nuevos para jóvenes y para niños, se inició un cambio visible. Porque es que lo que antes se hacía era que a todo el mundo le daban una serie de 52 semanas para todo el año y entonces se las repartían a 23 empresas y todo el mundo tenía una hora y así se llenaba la parrilla y no había tampoco ninguna estrategia de programación. (BENAVIDES, Marcela, informação verbal)

Germán Franco recorda que quando dirigia a Divisão de Comunicacão do Ministério da Cultura havia na Colômbia um movimento muito forte que reunia Adelaida Trujillo, Patricia Castaño, Marcela Benavides, também a brasileira Beth Carmona, convidada para os

\footnotetext{
${ }^{126}$ Encontrei com Germán Franco em Bogotá, no dia 19 de novembro de 2015, quando ele atuava como subdiretor do Centro Ático da Pontificia Univerisdad Javeriana.
} 
eventos no país, entre outras pessoas que defendiam a necessidade de financiamento para fazer produção de programação infantil. Franco assumiu essa defesa. "É dizer que eu não tomei a decisão sozinho, eu vinha respaldado por um movimento do setor”. Germán Franco acrescenta que, além da programação infantil, ocorreu o mesmo movimento com os documentários, com a comunicação étnica e com as rádios. "Eu vinha do setor e creio que interpretei o setor", reconhece o ex-diretor de Comunicações do MinCultura, também um cineasta.

Nas lembranças de Marcela Benavides ficaram marcadas as mudanças que provocaram as realizações do MinCultura quando esteve responsável por uma das faixas:

Otro gran cambio fue pensar en que, también, a fuerza de que nos dieron la parrilla de las 5 de la tarde a 11 de la noche, también queríamos hacer programación para niños pero entonces los horarios no parecían convenientes y empezamos a hacer contra-programación, entonces empezamos a programar por la noche para los niños, contra el prime y nos fue mejor, fue una cosa más bien casual. ¡Y nosotros empezamos a producir contenidos muy malos! Nuestros contenidos infantiles inicialmente eran muy malos porque venía la gente con el imaginario de diseñar lo que a ellos les hubiera gustado ver cuando ellos eran niños y no con la producción que se hace con los niños de hoy. Y romper con eso también fue algo muy difícil pero se generó un movimiento importante del sector independiente que viajaba a Prix Jeunesse y al empezar a ver las cosas que se hacen en el resto del mundo, se capacitan y funcionó todo muy bien. Básicamente eso fue lo que ocurrió como que en la primera etapa del canal.

Além desses exercícios de criação que provocaram as mudanças na percepcão da programação, Marcela relata que "hubo también un hito importante en el 2005 hasta el 2007, que fue la producción de dos contenidos que rompieron un poco la visión que tenían los televidentes de la televisión pública”. Segundo ela, demorou uns dois anos para se começar a ver no "ar" que estavam propondo "fazer e romper"com o que se vinha produzindo até então, que era un canal que tinha mescladas "cosas institucionales con cosas educativas-culturales y de niños" E quando, segundo descreve, começaram a ver uns conteúdos diários "frescos y nuevos para jóvenes y para niños, se inició un cambio visible" (BENAVIDES, informação verbal).

A excoordenadora da Señal destaca três programas que ficaram na história:

Uno que se llamó La sub 30 que fue un programa para jóvenes, que era programa para menores de 30 . El nombre, parte de que en futbol se dice a la selección juvenil la sub 20, entonces esto se llamó así. Este era un programa diario en donde había dos presentadores muy jóvenes que viajaron por todo 
el país haciendo el registro de toda la movida cultural de los jóvenes rurales, indígenas, pero también de los jóvenes urbanos mostrando clips, deportes, artes, audiovisual, cultura y se empezó a dar a conocer una cantidad de cosas. Este programa se volvió referente para enseñanza en facultades de comunicación y de cine porque a los muchachos les gustaba mucho. Entonces se volvió un programa para este nicho hasta entonces desatendido.

Marcela faz um parêntese para explicar o sucesso do programa: "Antes no había nada así, ya ahora hay muchas más posibilidades pues, en esa época no existía Netflix”. Foi algo que demonstrou, em sua opinião, que a televisão cultural podia ser divertida e com o mesmo orçamento se poderia fazer coisas que podiam ser interessantes para os nichos, "porque nunca fue masivo". Outro programa lembrado desse período foi Culturama, que "era un magazine cultural diario también, que tuvo ese espíritu de descentralizar". Para explicar a importância dessa descentralização, conta que a Colômbia, "es un país muy centralista y muy regionalista a la vez, hay 9 canales regionales y esos canales solo se miran a sí mismos y lo nacional, en realidad, es muy bogotano".

O grande objetivo desses programas na fase inicial da Señal foi mostrar o resto do país desde la mirada de ellos, de traerlos y fue también una cosa novedosa en ese momento". Para completar o foco para cultura, também o cinema marcou presença "se hizo una franja de cine, diaria, con una pequeña introdución, en donde alguien que era experto, un especialista, hacía una introducción temática o, según los ciclos, hablaba de cada una de las películas, dando un contexto". A repercussão foi positiva "la gente le escribía y él contestaba, y con un fuerte énfasis también en el cine colombiano". Marcela acrescenta que não foi só cinema ficção, também os documentários e curta-metragens entraram na programacão. "Y fue muy interesante porque en ese momento Señal Colombia empezó un posicionamiento de ser la casa del cine nacional. Y el cine también en Colombia, paralelo a todo esto, empezó a tener un crecimiento, en esta época se estrenaban tres películas anuales, hoy se estrenan 17”. (Grifo nosso)..”

\subsection{As trocas de gestores na Señal e a dança de cadeiras do andar superior}

Um paralelo ao que ocorre no Brasil diz respeito à instabilidade que afeta as gestões das entidades responsáveis pela comunicação pública na Colômbia. Como já referido, a Señal está subordinada à estrutura da RTVC. Os cargos para Gerência Geral, Subgerencia de Televisión, Subgerencia de Radio e Subgerencia de Soporte Corporativo são indicações do 
governo. Os cargos de coordenação direta das atividades fins, como coordenação das emissoras, são ocupados por cargos técnicos, embora possam ser de escolha dos gerentes e subgerentes, mas passam sempre pela definição de uma Junta que reúne várias entidades e representante da audiência. Não chega a ser uma blindagem às nomeações políticas, mas não é comum que elas ocorram nesse nível operacional. Para ilustrar, e como mais uma recorrência das ingerências e descontinuidades, reproduzo a nota sobre a nomeação pelo presidente da República de um novo gerente da RTVC, publicada no site do jornal $E l$ Espectador, em 19 de maio de 2015, e que foi também noticiada por El Tiempo, Semana, entre outros periódicos, contendo as mesmas informações:

\section{John Jairo Ocampo es nuevo gerente de RTVC Ocampo se desempeñaba como jefe de Prensa de la Casa de Nariño}

Este martes, el presidente Juan Manuel Santos oficializó el nombramiento de John Jairo Ocampo como el nuevo gerente de RTVC, en reemplazo de Lucy Osorno, quien se encontraba provisionalmente en el cargo. Ocampo es egresado de la Universidad Los Libertadores con especializaciones en Hacienda Pública en la Universidad del Rosario y en Derecho Económico de la Universidad del Rosario. Fue editor general del diario La República, dirigió la oficina de Comunicaciones de la Federación de Cafeteros y fue editor económico de Radionet, CM\&, Revista Cambio y RCN. Actualmente se desempeña como jefe de Prensa de la Casa de Nariño. "Ha sido un soldado fiel y leal, ahora pasa a comandar otro batallón que es RTVC", afirmó Santos, quien en la posesión le pidió acelerar la implementación de la Televisión Digital Terrestre (TDT), con el fin de que esté lista antes de que acabe su gobierno. ${ }^{127}$ (Grifos do jornal)

Aqui se constata uma similaridade com a EBC-TV Brasil. O gerente da RTVC, cargo similar ao de presidente da EBC, é indicação direta do presidente da República como mostra a nota acima do El Tiempo. A indicação representa também a "porta giratória”, como nomeiam em Brasília, o vai e vem de dirigentes da Secom para a EBC e vice-versa ${ }^{128}$.

O professor Omar Rincón, em seu depoimento, confirmou que esse processo de indicação política acontecia na RTVC: "En Colombia es lo mismo, o sea, el presidente de RTVC, que es la Radio y Televisión de Colombia era un tipo que era periodista de un canal

\footnotetext{
$127<$ http://www.elespectador.com/noticias/nacional/john-jairo-ocampo-nuevo-gerente-de-rtvc-articulo-561257>. Acessado em dez. 2015.

${ }^{128}$ Como tratado nesta tese, aconteceu na saída de Nelson Breve que voltou ao local de origem, a SECOM, como secretário de imprensa, quando da posse de Américo Marins. Breve ficaria pouco mais de 30 dias em sua segunda passagem pela Secom.
} 
privado y que luego fue el jefe de comunicaciones del presidente" (RINCÓN, Informação verbal). Ou seja, configurada a "porta giratória". Perguntei ao professor Rincón, se Jaime Tenorio, naquele momento coordenador da Señal, era também nomeado pelo presidente e ele esclareceu:

Tenorio es el director de Señal Colombia, pero encima de él hay una burocracia que es como la de TV Brasil. Ahí está Radio y Televisión de Colombia (RTVC), luego está Señal Colombia, Señal Institucional, Radionica, Radio Nacional de Colombia debajo de eso... Entonces, es como eso. Los directivos ahí (RTVC) son totalmente puestos por políticos, nunca nombran una persona que sepa de televisión, nunca nombran a nadie que sepa de lo público, nombran gente que pertenece al grupo de ellos...entonces corresponde a la misma lógica de Brasil y de toda parte, que es una lógica política, no una lógica televisiva, una lógica burocrática, no una lógica de concepto.

John Jairo Ocampo também deixaria o cargo com pouco mais de dois anos, como tomei conhecimento durante a realização do Festival comKids Prix Jeunesse Iberoamericano $2017^{129}$, que se realizou em São Paulo, entre 14 e 20 de agosto. Encontrei nesse evento Sandra Téllez, atualmente coordenadora do Mi Señal, a programação infantil da Señal Colombia. Estive com Sandra Téllez em Bogotá, quando ela trabalhava com Diana Diaz Soto no MinCultura. A dirigente do Mi Señal contou que tinham passado por mais uma mudança na direção da RTVC dias antes. Ela ainda não tinha muitas informações, porque a mudança era recente. Sandra falou das interrogações de todos com a chegada de um novo dirigente, como acontece nas mudanças também aqui no Brasil. Segundo a coordenadora do Mi Señal, alguns gerentes quando chegam decidem fazer mudanças nos processos, nas rotinas administrativas. O último, John Jairo Ocampo, nos dois anos em que ficou no cargo, não interferiu e deixou a Señal andar com autonomia.

Cheguei em casa naquela noite do dia 14 de agosto de 2017 e entrei no portal da Señal Colombia, o que não fazia há alguns dias, considerando que a tese estava praticamente fechada. Não resisti e mais uma vez busquei atualizar essa pesquisa, o que faço agora, transcrevendo parte da nota publicada no portal da Señal ${ }^{130}$, com o seguinte título José Jorge Dangond Castro, nuevo gerente de RTVC:

\footnotetext{
${ }^{129}$ Durante seis dias, o Festival reuniu em São Paulo produtores, diretores, realizadores de vários países da América Latina, além da Alemanha, Japão, África do Sul e Coréia do Sul, entre outros.

${ }^{130}$ Disponível em <https://www.rtvc.gov.co/noticia/jose-jorge-dangond-castro-nuevo-gerente-de-rtvc $>$. Acesso em 14 ago. 2017. Publicado em 4 ago. 2017.
} 
José Jorge Dangond Castro fue nombrado como nuevo gerente de RTVC Sistema de Medios Públicos, en reemplazo de John Jairo Ocampo Niño quien se desempeñará como Asesor de Comunicaciones de la Presidencia de la República.

A nota apresenta Dangond Castro com Administrador de Empresas, com "MBA de la Universidad del Norte y una Especialización del Harvard Business School”. Dangond Castro, conforme o registro, passou por vários cargos como Cónsul General de Colombia nas cidades de Valencia, Maracaibo e Caracas, diferentes atividades vinculadas ao Governo, entre eles, foi membro da Comisión Presidencial de Integración y Asuntos Fronterizos con Venezuela, por mais de 10 anos. O currículo informa ainda que ele reúne experiência em TV pública por ter sido fundador do canal regional Telecaribe, em 1986, e diretor executivo do Inravisión, entre 1994-1995 - o que pode preocupar os profissionais da Señal, considerando que quem conhece resolve mexer. A mudança mostrou mais uma vez a ocorrência da "porta giratória". John Jairo Ocampo Niño volta para as proximidades do presidente da república: "se desempeñará como Asesor de Comunicaciones de la Presidencia de la República”, posto que já ocupou antes de assumir a gerência da RTVC. O mesmo aconteceu na EBC, quando Nelson Breve deixou a presidência da empresa e retornou à assessoria de comunicação da presidente Dilma Roussef, como já informado.

O novo dirigente da RTVC fez o gesto de cordialidade ao presidente, com a seguinte mensagem de agradecimento:

\footnotetext{
Para mí es un honor haber sido designado por el Presidente Juan Manuel Santos para asumir la gerencia de RTVC. Trabajaremos de la mano con el Ministerio de Tecnologías de la Información y las Comunicaciones y asumiremos retos importantes como el seguir ampliando la cobertura por medio de la descentralización de la radio, continuar con la programación de contenidos incluyentes y trabajaremos por llevar la televisión digital a todos los hogares.
}

Pelo que adiantou, Dangond Castro trabalhará com o Ministério das Tecnologias da Informação e das Comunicações (MinTIC), dará continuidade à expansão da cobertura através da descentralização da rádio, à programação de conteúdo inclusivo e ao projeto para levar a televisão digital a todos os lares $\mathrm{O}$ nome do novo gerente, de acordo com a nota, foi indicação do ministro David Luna (MinTIC). A nota informa ainda que o novo gerente enfrentará desafios além da descentralização da rádio pública: fortalecer o projeto que 
preserva a memória histórica colombiana de áudio e vídeo, e também realizar a transição da televisão analógica para a televisão digital em todo o território nacional. Como se lê na nota publicada no portal da Señal, Dangond Castro será o primeiro dirigente que já teve alguma experiência com TV pública, ao contrário de outros, como relatou Omar Rincón.

Perguntei a Rincón em 2015 se a Señal Colombia e a Pakapaka, canal infantil público argentino (com a separação do institucional), eram uma alternativa para impedir a ingerência governamental no canal público, ele afirmou que a Colômbia tomou uma decisão que o Brasil já teve, quando os canais federais - Radiobrás e Acerp/TV Brasil - eram organizações distintas, ou seja, não estavam no mesmo guarda-chuva como a EBC hoje. ${ }^{131}$

No caso da Colômbia, há uma perspectiva positiva em relação à coordenação do canal, segundo Diana Díaz: “Aquí hay una ley que controla, que prohíbe la "puerta giratoria”, es decir, yo por ejemplo fui durante unos meses Jefe de la Oficina de Contenidos y Defensoría del Televidente de la Comisión Nacional de TV. Terminado esos seis meses yo no pude trabajar en ningún canal de TV por dos años. No pude trabajar hasta que pasara una ventana de dos años. Y ahora (2015) tampoco estoy en ningún canal, sino en el Ministerio" (Informação verbal) $)^{132}$

A experiência de Marcela Benavides, que dirigiu a Señal Colombia, durante sete anos e saiu por decisão própria, não representa um fato normal, em relação ao que ocorre na instituição gestora, a RTVC. "Señal Colombia en estos 15 años há tenido demasiados cambios en sus diretivos, ha tenido ya siete o ocho gerentes (RTVC) ${ }^{133}$, que es mucho, lo que resta possibilidades de continuidad y de consolidación de procesos y los cambios de los directores del canal y demás". Segundo ela, desde que foi instituída, a RTVC tem sido perseguida pela instabilidade - em 10 anos teve sete gerentes (média de 17 meses), o que impacta na continuidade dos processos. "Se ha tenido que empezar una y otra vez". Ela alerta: "El perfil político y falta de experiencia específica en televisión de muchos altos funcionarios ha desviado el camino varias oportunidades impidiendo que la consolidación del proyecto se de a más largo plazo". (Grifo nosso)

\footnotetext{
${ }^{131}$ A Señal não tem jornalismo. Na perspectiva dos colombianos entrevistados, o jornalismo é a porta de entrada das ingerências políticas.

${ }^{132}$ Passado o período de dois anos, Diana voltou à Señal como sua dirigente, conforme relatamos.

${ }^{133} \mathrm{Na}$ hierarquia, o cargo de gerente é superior ao coordenador do canal Señal, este sim uma escolha que passa por um processo seletivo. Na gerência há rotatividade e estes, algumas vezes, criam dificuldades burocráricas para o exerciocio do trabalho de produção de conteúdos, conforme afirmaram alguns entrevistados.
} 
Ainda no período em que trabalhou como "produtora delegada" (responsável por acompanhar o trabalho dos produtores independentes), teve três chefes diferentes - "como coordinadores de canal y sugerentes". Segundo seu depoimento, cada vez que chegava um deles, era preciso explicar "porque se hacia todo esto. Porque les parecia que era muy enredado, y que no había necessidad, que más fácil era contratar la gente y ya no poderse a hacer ningún tipo de seguimiento, ni tan intenso... Y volver a convencerlos." Segundo Marcela, os produtores delegados eram uma equipe super unida e cada vez que havia uma mudança, "así como soldados - defendiendo que no fueran a cambiar eso - porque casi siempre venían com ideas de traer sus personas cercanas". (Informação verbal).

Marcela lembra de quando trabalhou como produtora delegada, como tempos de muito aprendizado:

En esa época entonces, como productora delegada, yo tenía muy claro todo esto que era lo que se había implementado y era tratando de ponerlo en marcha, porque desde afuera lo que yo había hecho era asesorarlo, escribirlo y proponerlo pero no ejecutarlo. Entonces ahí, pues, teníamos a cargo cada uno más o menos unos 7 proyectos.

Experiência de descontinuidades similar a de Marcela Benavides teve o coordenador que a substituiu na Señal Colombia, Jaime Tenório. Também ele se referiu às mudanças de gerentes. Conversei com Jaime Tenorio, em Bogotá, em 18 de novembro de 2015, às vésperas de ele completar dois anos na coordenação da Señal Colombia, onde tinha ingressado em 30 de dezembro de 2013. Naquele encontro ele relatou que "en prácticamente año y médio tuvimos tres gerentes". Tenório não ficou muito mais tempo no cargo. Deixou a emissora no final de fevereiro de 2016. Portanto, completou pouco mais de dois anos. Trocamos mensagens pelo WhatsApp meses depois de ele ter deixado o cargo quando contou que havia retornado ao setor privado. Posteriormente trocamos mensagens por email e ele narrou rapidamente os motivos de sua saída:

Como lo había comentado en la entrevista, en año y medio tuve tres gerentes, y estos cambios me desgastaron mucho. Cada gerente viene con un nuevo método de trabajo y suelen cambiar a las áreas administrativas como el área jurídica, planeación, etc, esto implica cambios en los procedimientos y procesos. Venía de trabajar mucho tiempo en el sector público y se me presentó la oportunidad de irme al sector privado. ${ }^{134}$ (Grifo nosso)

\footnotetext{
${ }^{134}$ Mensagem recebida por limilanez@gmail.com em 5 dez. 2016.
} 
Assumiu a direção da Señal Colombia, em substituição ao Jaime Tenorio, Diana Díaz Soto, quando ela atuava como coordenadora do Proyecto de Comunicación, Cultura y Niñez na direção de Comunicações do Ministério de Cultura. Diana, como já citado, teve papel relevante nos estudos que antecederam a transição para a Señal Colombia em 2004, quando foi criada a RTVC e extinto o Inravisión; e também na implantação do novo canal como productora delegada. Respeitada na Colombia, como especialista e grande conhecedora de televisão, reconhecida pela competência e talento por Omar Rincón e pelos seus pares na América Latina, com quem partilha nos encontros internacionais como o Prix Jeunesse, Diana em uma troca de mensagens pelo Messenger (Facebook), explicou como havia sido formulado o convite para assumir a Señal Colombia:

La invitación original fue a coordinar la franja infantil Mi Señal y seguir también vinculada con el proyecto de niñez en el Ministerio de Cultura. Al mes haber iniciado renunció el director del canal (Jaime Tenorio), abrieron un proceso de convocatoria y me presenté. Felizmente quedé seleccionada. Ahora la idea es fortalecer y evolucionar nuestros módulos de programación: infantil, ficción, no ficción, deportes. Quedo atenta a cualquier duda. (Informação pessoal) ${ }^{135}$

Foi, como se pode concluir, uma escolha a partir de seleção, e não uma indicação política. Adoto a palavra escolha porque ela participou de um processo seletivo e foi escolhida, certamente, pelas suas qualificações e histórico de realizações já demonstrados na própria Señal Colombia. No contato que tivemos em Bogotá, Diana também abordou as mudanças de gerentes que ocorriam por questões políticas. Segundo ela, "si un gerente alcanza 1 o 2 años en la dirección es mucho"136 (Informação verbal). Na opinião da atual dirigente, o que salva a Señal das consequências dessas mudanças é a rede de proteção formada por produtores independentes e profissionais que participaram das discussões que resultaram na grande mudança em 2004, com a criacão da RTVC e Señal Institucional.

Segundo Diana, criou-se uma rede de proteção ao projeto que resiste à qualquer tentativa de interferência, embora "esta sempre possa ocorrer". Como já referido, segundo a dirigente, há uma lei que pró́be a "porta-giratória". Ela ficou afastada de cargo diretivo por dois anos, depois de ter trabalhado como "Jefe de la Oficina de Contenidos y Defensoría del Televidente de la Comisión Nacional de TV", por seis meses. "No pude trabajar hasta que

\footnotetext{
${ }^{135}$ Informação recebida por Messenger, Facebook, em 28 nov. 2016.

136 E foi mais uma vez esse mesmo tempo que permaneceu o gerente anterior, John Jairo Ocampo, pouco mais de dois anos.
} 
pasara una ventana de 2 años, sino en el Ministerio de Cultura” (DÍAZ, Diana. Informação verbal). Passaram-se esses dois anos e ela pode retomar as atividades, agora como coordenadora da Señal Colombia. Repito a informação para destacar essa salvaguarda como mecanismo para preservar a instituicão, diferente do Brasil.

\subsection{Estrutura e operação da RTVC segundo seus protagonistas}

No nosso encontro em novembro de 2015, quando ainda estava no Ministério de Cultura, Diana Diaz fez ampla descrição do que era a RTVC, embora já citado, aqui repito conforme atesta a atual dirigente da Señal:

RTVC que es la Radio Televisión de Colombia - Sistema de Medios Públicos y a su vez Señal Colombia y RTVC está mas en la organización del Ministerio de las TIC (Tecnologías de la Información y la Comunicación) pero en la Junta Directiva de Señal Colombia y del Comité Programación, tienen asiento también el Ministerio de Educación y el Ministerio de Cultura. En la parte de la junta directiva digamos que es el órgano de RTVC en el que se van guiando las decisiones que se toma la gerência y en el Comité de Programación es mas un organismo de vigilancia, es mas de consulta, como una instancia consultiva de las decisiones de Programación que se toma la Señal Colombia. (Grifo nosso)

Também Marcela Benavides, ex-diretora da Señal Colombia se referiu ao funcionamento canal do ponto de vista burocrático e organizacional: "administrativamente RTVC y Señal Colombia han dependido del Ministerio de Comunicación y Nuevas Tecnologías por su relación con la administración y mantenimiento de antenas, redes y administración del espectro". Pelo que se testemunha na distância e via internet neste 2017, com o MinTIC indicando o dirigente da RTVC, os desafios apresentados na posse do novo dirigente podem chegar também à programação. Tudo ainda é incógnita, como deu a entender Sandra Téllez, coordenadora do Mi Señal, em São Paulo. Todos torcem para que o canal siga com sua programação e que continue conquistando prêmios, como aconteceu mais uma vez no Festival comKids Prix Jeunesse Iberoamericano 2017 e narraremos adiante. ${ }^{137}$

\footnotetext{
137 Disponível em $<$ http://comkids.com.br/vencedores-do-festival-comkids-prix-jeunesse-iberoamericano2017/>. Acesso em 21 ago. 2017.
} 


\subsection{A recuperacão da memória da rádio e televisão colombianas}

Conversei em Bogotá (23/11/2015) com a historiadora e diretora do Proyecto Señal Memória, Tatiana Duplat, responsável por todo o acervo e recuperação da memória da televisão e rádios vinculadas à RTVC. Ela narra pela perspectiva histórica um pouco do que são os veículos ali agrupados e a preocupação hoje de recuperar documentos:

En el sistema de medios públicos está la Radio Nacional de Colombia y una emisora joven que se llama Señal Radiónica, que es una derivación de la Radio Nacional especializada en público juvenil, y como quinto elemento de ese sistema de medios públicos tenemos la Señal Memoria que no es un medio, ni una emisora, ni una TV, es un proyecto. Ese proyecto busca recuperar el archivo audiovisual y sonoro, el archivo de la TV y el de la radio y convertirlo en un archivo patrimonial, un archivo para el país para que pueda alimentar las discusiones públicas de lo que hemos sido y de lo que queremos ser. El proyecto Señal Memoria reúne 61 años de historia de la TV colombiana y 75 años de historia de la radio.

Me entusiasmo com a narrativa de Tatiana Duplat, sigo atenta ao percurso da rádio e televisão pública na Colômbia, para entender a partir do passado, este presente, e a preocupação que demonstram com o Projeto Memória:

La radio se creó en Colombia en el año 40 y la televisión en el año 53 y se fueron acumulando los registros, las cintas, los soportes, se fueron acumulando y acumulando hasta que llegó a ser inmanejable, muy difícil de sostener, pero ahí estaba, lo tenían, lo guardaron, y en el 2004 cuando se acaba Inravisión (Instituto Nacional de Radio y TV), se liquida administrativamente. Fue una época muy difícil, muchos problemas económicos, una planta muy grande, un sindicato también muy complicado. Esto lleva a que se liquida el Instituto Nacional de Radio y TV (Inravisión), que era inmenso, y se crea RTVC, esto que te estoy contando. Del 2004 hacia acá es la RTVC. Y en ese momento, en 2004, cuando se va a crear RTVC, el decreto que la crea dice "el archivo de la Radio Nacional es muy importante!", y se garantiza por decreto que ese archivo tiene que tener una gestión y un cuidado especializado, y desde el 2004 hacia acá, sobretodo desde el 2006 hacia acá, ya hay acumulado una experiencia gestionando la Fonoteca. Entonces nuestro archivo existe antes del proyecto Señal Memoria. El archivo es más viejo que nuestro propio proyecto.

Segundo Tatiana Duplat, antes da criação do projeto Señal Memória o acervo estava a cargo da videoteca, onde trabalhavam técnicos de arquivo bibliotecários. Em 2013, é criado o

Señal Memória e, em 2015, ela assume a coordenacão. Como o projeto envolve altos custos, 
recebem recursos da ANTV e do Ministério de Tecnologias da Informação (MinTIC). Usufruo de alguns momentos de sua narrativa, a partir do fim do Inravisión, já abordado nesta tese, mas com outra perspectiva: “Termina el Inraivisón y se crea RTVC como una empresa social y comercial del Estado. Funciona como un instituto mixto. Es una empresa comercial y industrial del Estado, es decir, tiene que generar ingresos, poder vender servicios, cambian el modelo".

Para Duplat, a grande mudança na Señal foi a criação das "convocatórias". Enquanto a Señal recebe recursos do FONTV, o canal Institucional "le venden los servicios a las instituciones dentro del mismo estado". Em relação às rádios, Tatiana afirma:

\footnotetext{
"la Radio Nacional que no ha dejado nunca de funcionar, ha estado siempre muy estable. Y hace 10 años (en 2005) se crea la otra emisora, Radiónica. Ya con una idea de especializar más al público y ultimamente como una manera casi de experimento, han puesto en internet Señal Clásica y han hecho intentos con un canal dedicado al rock, Señal Rock. Todos en la web. Este es el panorama.
}

No decorrer dos tempos, foram se acumulando os arquivos, sem muita organizacão. Em relacão à rádio, Duplat informa que "en el 2004, por suerte el decreto dice 'la Fonoteca, hay que gestionarla y dedicarle recursos"”. A Fonoteca, que antecedeu a criação do projeto Señal Memoria, tentou durante 10 anos organizar este acervo; atualmente o de rádio está "más o menos organizado". A Fonoteca fazia parte da Radio Nacional e o que fez ao longo de um tempo foi recuperar os arquivos, fazer a digitalização e organizar o catálogo. (Tatiana Duplat, informação verbal).

Para Marcela Benavides, "el mayor logro de los últimos años de allá es Señal Memoria porque sí creo que estaba descuidado todo el tema del archivo de la catalogación". Benavides aproveita para lembrar do superior que teve a sensibilidade para pensar no acervo: "Nosotros tuvimos un subgerente, en el 2007, en televisión que venía de trabajar en Discovery y él tenía una mirada muy clara... él fue el único de todos los jefes que había, que había trabajado en televisión, tenía una mirada muy de televisión”. Marcela Benavides considera o Señal Memória “es lo máximo", yo estava allá quando empezó en el 2013. Apenas este año (2015) está empezando a mostrar cosas". A ex-dirigente também lembra que o acervo da rádio estava bem organizado e catalogado, 
instalaciones donde tienen las cavas y las neveras para tener todo en buen estado. Pero, por ejemplo, cuando pasó esto en INRAVSION, que cerraron, fue violento porque entonces estas 600 personas se quedaron sin trabajo. Ellos se tomaron las instalaciones y entiendo que se robaron parte de los acervos, se llevaron mucho, mucho, mucho. Fue una forma de protesta. Eso nunca se recuperó. No se sabía que había para poder saber qué hacía falta.

Tatiana Duplat também se referiu ao desvio de material dos arquivos por funcionários afastados. Recordo que quando realizei a pesquisa para os livros TVE Brasil - Cenas de Uma História e Rádio MEC - Herança de um Sonho, ouvi de muitos ex-funcionários que o pessoal quando saía levava suas produções que estavam no arquivo. E foi durante esse trabalho de pesquisa para os livros que Beth Carmona decidiu investir no Departamento de Acervo e Pesquisa, trazendo |pessoas qualificadas, com investimentos na digilitalizado e recuperação de arquivos. $\mathrm{O}$ mesmo processo de recuperação de acervo empreendemos na rádio $\mathrm{MEC}$ quando estive na gerência executiva, com apoio da direção da ACERP. A EBC herdou um legado de trabalho de recuperação da memória das emissoras que espero continue sendo preservado e recuperado.

\subsection{Independência - o clamor e a defesa de protagonistas e colaboradores}

Na pesquisa de campo realizada em Bogotá, na Colômbia, tive oportunidade de conversar com pessoas referenciais para o estudo da televisão pública naquele país. Infelizmente, não foi possível retornar em 2016, como previsto, para a segunda etapa da pesquisa. O tempo curto e as distâncias impediram naquele novembro de 2015, outras conversas programadas em encontros pretendidos com Paula Arenas, assessora de conteúdos da RTVC, Jesús Martín-Barbero, Guiomar Acevedo e o gerente da RTVC naquela oportunidade, John Jairo Ocampo que havia sido indicado para o cargo em 15 de maio daquele ano (2015). Os encontros realizados, no entanto, permitiram entender o funcionamento da televisão pública na Colômbia, assim como passagens de sua história.

Pelo amplo material que recebi, entre publicações, documentos e livros, além das reportagens veiculadas pelos jornais do país, que sigo pela internet, foi possível perceber que há um sentimento de proteção ao canal que, embora não alcance a totalidade dos "televidentes", congrega boa parte do público, das universidades, escolas, professores, estudiosos e da mídia impressa, como mostramos com algumas transcrições. 
Entre as pessoas que destaquei acima, Paula Arenas, assessora de conteúdos da Señal teve papel relevante nas discussões que antecederam a grande mudança em 2004. Seu artigo no Boletim Cultural y Bibliográfico conclui com uma afirmação que exemplifica a união pela defesa da TV pública a que me referi: "la televisión pública no sobrevive sola, no puede ni debe estar sujeta a las leyes del mercado, solo en la medida em que se sumen esfuerzos, incluídos los televidentes para que reclamem el servicio como um derecho, podrá salir adelante". Ela completa congregando a defesa desse meio: "a quien interese este país, le interessa la televisión pública, la que ojalá fuera nuestro mejor espejo y la más interesante e indiscreta de las ventanas (ARENAS, 2015, p. 50).

\subsection{Caminhos para a televisão pública}

Alexandra Falla ${ }^{138}$, diretora do Patrimonio Filmico, também falou sobre suas expectativas:

Finalmente en Colombia la TV pública ha venido fortaleciéndose y ha venido ganando espacios, por ejemplo la gente no se imagina su región sin su canal regional, quieren su canal regional sobretodo ven sus noticias del canal regional, porque el nacional no los cubre realmente, y no dice lo que está pasando en la esquina, allá, en el pueblo, en la ciudad de... Entonces digamos que tiene un nicho importante, yo creo que ha venido fortaleciéndose y tiene con la ANTV una oportunidad de fortalecimiento de no morir, no? Siempre es una oportunidad, pero es un riesgo.

Para vencer as possíveis pressões políticas, todos destacam que a realização de um bom trabalho e uma programação de qualidade são a salvaguarda do canal. De acordo com Diana Diaz, atual coordenadora,

Señal Colombia viene trabajando sobre un proyecto que se ha venido consolidando con el tiempo. Es muy difícil que desde la política - sola -, se destruya. Se necesita que haya otros factores. Porque ahora hay otros factores, como la convergencia, las multiplataformas, que están implicando al canal reformularse de muchas maneras. Apenas con la política es muy difícil que desaparezca el Proyecto como está porque, por ejemplo, franjas como Mi Señal han venido consolidándose ante los niños, ganan premios, eso" (Informação verbal).

138 Depoimento concedido em novembro de 2015, em Bogotá. 
E essa consolidação da Mi Señal, a programação infantil, é reconhecida na América Latina, como ocorreu no já citado Festival comKids Prix Jeunesse Iberoamericano. A Señal não só marca presença nesses eventos como reafirma, através das premiações e da presença de seus profissionais, sua determinação em lutar pela preservação da autonomia conquistada, inviabilizando, de certa forma, qualquer ação autoritária de parte do governo. 


\section{TV pública: a eterna desconstrução}

\subsection{TVE Brasil, ontem. TV Brasil, hoje - Os antecedentes}

O equívoco consiste em transportar a ideia de governo para processos que não o permitem. O conceito de ingovernabilidade habitualmente acompanhado com um gesto de desagrado - reflete uma exigência excessiva que dirigimos à política: manusear o que não pode ser manuseado. A esperança de resolver os problemas de pilotagem das sociedades complexas baseia-se em ter-se confundido a condução de grupos e de veículos com o governo do que não é um grupo nem um veículo. (INNERARITY, Daniel, 2002, $24^{139}$ )

No Brasil, as emissoras hoje tratadas como "públicas" - e que já foram nomeadas de "educativas" e "educativas e culturais" - padecem de um mal que persiste desde seus primórdios: o da descontinuidade. São as trocas de gestores, de políticas de programação e de formas de gestão. São sucessivamente novos dirigentes que chegam com suas equipes para ocupar os assim chamados "cargos de confiança", um eufemismo para cargos de governo. Implantam, cada um, uma espécie de "estilo" ou de "visão" de programação, muito mais atentos ao serviço governamental do que à preocupação social como instituições públicas.

Numa espécie de ciclo recorrente, a substituição de equipes governamentais tende a responder a interesses de governo em detrimento aos interesses de Estado. As consequências são percebidas na programação e na desestruturação do quadro funcional permanente do aparato de Estado (ou os "estabelecidos", invertendo o conceito de Norbert Elias e John $\left.\operatorname{Scotson}^{140}\right)$.

Com estas características e com as agudas críticas sobre a baixa audiência, não só é preciso reconhecer que essas instituições têm sobrevivido, como oscilam em termos de

\footnotetext{
${ }^{139}$ INNERARITY, Daniel. A transformação da política. Lisboa: Teorema, 2002, p. 24.

${ }^{140}$ ELIAS, Norbert, SCOTSON, JOHN. Os Estabelecidos e os Outsiders. Jorge Zahar Editor. Rio de Janeiro, 2000. Os autores observaram as relações existentes em uma pequena comunidade da periferia, na Inglaterra, que apontava uma clara divisão entre um grupo "estabelecido" desde longa data, e outro mais novo de residentes, cujos moradores eram tratados como "outsiders". A única diferença entre os dois grupos era o tempo de residência no lugar, mas os primeiros, ao se acharem superiores, exerciam o poder, "reservando para as pessoas de seu tipo os cargos importantes das organizações locais". Usei as classificações dos autores, invertendo as posições, para designar os cargos de confiança, como os outsiders, que chegam às emissoras com o poder de decisão, enquanto os estabelecidos, os funcionários permanentes, submetem-se às decisões dos primeiros, muitas vezes alijados da rotina de atividades a que estiveram envolvidos em períodos anteriores.
} 
qualidade e de atenção por parte dos dirigentes governamentais. Ou seja, apesar de todos os policies - conselhos curadores e deliberativos, manuais de conduta, códigos de ética, regimentos internos e leis - elas são, em sua maioria, empresas de governo e não de Estado, a exemplo de outras estatais brasileiras e latino-americanas. Os conselhos, cujos "membros deveriam representar os interesses da comunidade junto às agências governamentais" (MIOLA, Edna, 2009) e preservar as características de interesse estatal das instituições podem ser, e geralmente são, "contaminados" ao terem os nomes de seus componentes indicados pelo próprio governo. Para Laurindo Leal Filho (1997, p. 20), “a autonomia absoluta das emissoras em relação aos governos não existe. O que varia é seu grau de interferência. De modo geral as emissoras são dirigidas por conselhos diretores, um modelo adotado inicialmente pela BBC, na Grã-Bretanha, e que se tornou exemplo para países como Itália, Alemanha, Austrália, Japão, Nova Zelândia e o estado de São Paulo, no Brasil, com sua Fundação Padre Anchieta". No entanto, ressalva o estudioso, a forma de escolha dos membros dos conselhos e o tipo de financiamento é o que acaba por determinar a influência do governo. $^{141}$

\subsection{A percepção de Louk de La Rive Box}

As situações de "descontinuidades e ingerências" que se observam nas emissoras públicas no Brasil, vêm de longe, desde as primeiras experiências com o que se chama hoje de educação a distância. A tele-educação foi o embrião das TVs educativas no Brasil, conforme observação do pesquisador e professor norte-americano Louk de la Rive Box. Box viveu no Brasil entre agosto de 1969 e agosto de 1970, onde fez a pesquisa de sua tese - Organization of Educational Broadcasting in Brazil - defendida, em 1973, na Universidade de Columbia ${ }^{142}$. Nela, o pesquisador constatou as descontinuidades vividas pelos veículos dedicados à teleeducação em decorrência dos revezes da política, em especial no período da Ditadura, que ele

\footnotetext{
${ }^{141}$ Recordo aqui manifestação de Beth Carmona quando ainda presidente da extinta TVE Brasil (2003-2007) no primeiro mandato do presidente Lula, durante as discussões preparativas para do I Fórum Nacional de TV's Públicas em 2007"141: "mesmo sofrendo a descontinuidade de gestão, as interferências políticas, a falta de investimento tecnológico e em pessoal, a síndrome da baixa estima, a pouca audiência, a falta de recursos de produção, a concorrência dos conteúdos de apelo fácil, - (a TV pública) vive e sobrevive."

${ }^{142}$ MILANEZ, Liana. TVE Brasil - cenas de uma história. ACERP, Rio de Janeiro, 2007.
} 
testemunhou diretamente. Em maio de $2006^{143}$, quando ele era reitor do International Institute of Social Studies, com sede na Holanda, formulou uma acertiva direta: disse que o que se passara com a TVE havia acontecido nas primeiras décadas do século XX com o rádio, um projeto inicialmente também voltado à educação. Uma história de longo tempo. ${ }^{144}$

A Rádio Sociedade pode ser considerada a mais pública das emissoras surgidas no Brasil desde os anos 1920. Tendo à frente o antropólogo e cientista Edgard Roquette-Pinto, o Brasil estava entre os primeiros países do mundo nas experiências com o rádio. Roquette comandou o processo de criação da Rádio Sociedade no Rio de Janeiro. Essa rádio enfrentaria, 13 anos depois, o primeiro atropelo. Louk Box lembra o episódio ocorrido em 1936, quando da doação da Rádio Sociedade, mantida desde sua fundação, em 1923, por um grupo de sócios da Academia Brasileira de Ciências. A intenção era doar, em 1936, a emissora ao Ministério da Educação e Saúde, no governo Getúlio Vargas (1930-1945), para que continuasse a serviço da educação. Em carta encaminhada ao ministro Gustavo Capanema, Roquette consultava se o Ministério aceitaria a rádio, com todos os equipamentos e acervo e com uma única condição: que permanecesse fiel ao seu lema cultural e educativo, sem qualquer vinculação comercial, política ou religiosa. (MILANEZ, Liana. 2007) Capanema respondeu que o presidente Getúlio Vargas aceitava e agradecia, mas sugeria que a supervisão fosse feita pelo Departamento de Propaganda e Difusão Cultural (DIP). Roquette revidou, destacando que a doação seria feita "ao Ministério da Educação do povo, não ao governo". O ministro Capanema retornou com a garantia de que o Ministério aceitava a doação nos termos em que fora proposta. Roquette antevia que o DIP se tornaria o órgão de controle máximo da imprensa e da propaganda pelo Estado Novo ${ }^{145}$.

O acordo entre Capanema e Roquette foi a salvaguarda que garantiu, durante algum tempo, a integridade da rádio, que passou a se chamar Rádio Ministério da Educação, mais tarde Rádio MEC. Um acerto legal que impediria por longos anos as diversas tentativas de órgãos governamentais se apoderarem da emissora para fins diversos. Mas não foi o bastante. Em 1988, sob a presidência de José Sarney, a Fundação Centro Brasileiro de TV Educativa -

\footnotetext{
${ }^{143} \mathrm{Em}$ uma troca de emails quando eu estava na fase inicial da pesquisa para a elaboração dos livros sobre a Rádio MEC - Herança de um sonho, e TVE - Cenas de uma história.

${ }^{144}$ A TVE Brasil, criada em 1973, já com mais de 30 anos de operação, deixaria de existir ao ser incorporada pela EBC. Foi mais uma desconstrução para surgir novo projeto de comunicação, incialmente com os mesmos profissionais e a mesma programação. Ou seja, não foi a primeira emissora pública criada no Brasil, como se escuta em distintas plenárias.

${ }^{145}$ CASTRO, Ruy. Roquette-Pinto: o homem multidão. In: MILANEZ, Liana Rádio MEC: Herança de um sonho. ACERP, Rio de Janeiro, 2007.
} 
Funtevê, à qual a rádio estava então vinculada, juntamente com a TVE, passou a integrar o Sistema de Comunicação da Administração Federal, ligado ao Gabinete Civil da Presidência da República. A mudança contrariava os desejos dos criadores tanto da Rádio MEC, Roquette-Pinto, quanto da TVE, Gilson Amado. Um ano depois, em 1989, a Funtevê voltou ao Ministério da Educação e Cultura, onde não ficaria por muito tempo. Com novo nome Fundação Roquette-Pinto (FRP) -, em 1995, e já no governo Fernando Henrique Cardoso, a FRP passou a integrar a Secretaria de Estado de Comunicação, SECOM.

Na mesma gestão de FHC, em 1997, a Fundação Roquette-Pinto foi substituída por uma Organização Social (OS), a Associação de Comunicação Educativa Roquette-Pinto (ACERP). Em 2007, dez anos depois, com a criação da Empresa Brasil de Comunicação, pelo Decreto 6.246/2007 (outorgado posteriormente pela Lei 11652/2008), a ACERP ${ }^{146}$ passou a ser uma espécie de fornecedora de programação com a disponibilização de seu quadro funcional, situação que se manteria até a incorporação, pela EBC, de todos os veículos federais de comunicação, e realização de concurso público para preenchimento de cargos ${ }^{147}$. Esse processo se prolongou até 2013, quando a EBC encerrou o contrato de gestão com a ACERP $^{148}$. Os profissionais que vinham trabalhando até então na TV Brasil, oriundos da TVE Brasil e rádios MEC, foram todos dispensados. Muitos já com algumas décadas de dedicação àquelas emissoras.

$\mathrm{Na}$ troca de emails a qual me referi anteriormente e que teve lugar ainda em 2006, o professor Louk Box se citou outro acontecimento que também teve a marca da descontinuidade. Desta vez, impedindo o nascimento do primeiro canal de televisão voltado à educação no País: a tentativa frustrada do pioneiro do Rádio no Brasil, Edgard RoquettePinto, de implantar uma Televisão Educativa, em 1952. Devido a mudanças de ordem política, a saída forçada do prefeito do Distrito Federal João Carlos Vital, que apoiava a implantação da Televisão Educativa, e a entrada do cel. Dulcídio Cardoso, contrário à ideia, o projeto foi interrompido quando já estava com equipamentos encomendados dos Estados

\footnotetext{
146 Como Organização Social, a ACERP mantinha seu contrato de gestão com a SECOM. Com a criação da $\mathrm{EBC}$, esses contratos passam a ser feitos com essa empresa.

${ }^{147}$ Contrato de Gestão $\mathrm{n}^{\circ} 17$ celebrado entre a EBC e a ACERP em março de 2009. Disponível $\mathrm{em}:<$ http://www.ebc.com.br/acessoainformacao/wordpress/wpcontent/uploads/2012/04/Contrato 01822009 acerp.pdf $>$. Acesso em 2 jan. 2015.

${ }^{148}$ Portaria-Presidente no 229 A - Projeto de Absorção das Atividades da ACERP pela EBC - 15/04/2013. Disponível em: $\quad<$ http://www.ebc.com.br/acessoainformacao/wordpress/wpcontent/uploads/2013/03/PORTARIA-PRESI-N\%C2\%BA-229-A-PROJETO-DE-ABSOR\%C3\%87\%C3\%83ODAS-ATIVIDADES-DA-ACERP-PELA-EBC.pdf $>$. Acesso em 2 jan. 2015.
} 
Unidos e todo o planejamento concluído. ${ }^{149}$ Como consequência, a implantação de uma televisão educativa brasileira, conforme o sonho de Roquette, "perdeu duas décadas". O Canal 2 só seria ocupado como um canal educativo em 1973, conforme o Decreto $\mathrm{n}^{\circ} 72.634$, de 16 de agosto daquele ano, que "outorgou à Fundação Centro Brasileiro de Televisão Educativa (FCBTVE), que já atuava na produção de programas educativos, a concessão para o estabelecimento de estação de radiodifusão de sons e imagens". (MILANEZ, 2007, p. 27) ${ }^{150}$

\subsection{Gestões temporárias - as trocas de assento}

As descontinuidades começaram pelos nomes. Nascida Fundação Centro Brasileiro de TV Educativa - FCBTVE (1967-1981), passou a se chamar Fundação Centro Brasileiro de TV Educativa - FUNTEVE (1981 - 1990), depois Fundação Roquette-Pinto - FRP (1990-1997) e, por último, Associação de Comunicação Educativa Roquette-Pinto - ACERP - (19972007). As emissoras TVE Brasil, Rádios MEC e TVE Maranhão, geridas por essa sequência de instituições foram incorporadas pela EBC em 2007. Desta vez mudaria também o nome da emissora - a TVE Brasil deu lugar à TV Brasil.

A dança de cadeiras acompanhou o movimento. Em um período de 19 anos, depois da morte do fundador da FCBTVE, Gilson Amado, em 26 de novembro de 1979, passaram pela instituição 16 presidentes. As trocas eram tantas, que em pouco mais de um ano, entre julho de 1989 e outubro de 1991, o assento de presidente da Fundação teve três ocupantes. As mudanças não se restringiam às trocas de governo. Depois de Gilson Amado, que permaneceu à frente da Fundação por 11 anos (1967-1981), a gestão mais duradoura, que cumpriu um ciclo de quatro anos, foi a de Beth Carmona (2003-2007), durante o primeiro mandado do presidente Luiz Inácio Lula da Silva, e que permaneceu até a criação da EBC, quando Tereza Cruvinel assumiu o cargo de primeira presidente da EBC, escolhida pelo então presidente Lula. O mandato de quatro anos da jornalista terminou em 31 de outubro de 2011. Foi substituída pelo jornalista Nelson Breve, que tomou posse em $1^{\circ}$ de novembro de 2011.

\footnotetext{
${ }^{149}$ MILANEZ, Liana. TVE Brasil - cenas de uma história. ACERP, Rio de Janeiro, 2007, p.23-27.

${ }^{150}$ Ibid. p. 35 .
} 
Breve deixou a presidência da EBC e, cruzando a "porta giratória ${ }^{151}$," voltou à Secom, para assumir a Secretaria de Imprensa. Em sua coluna no Portal da Carta Capital, o Intervozes criticou a dança das cadeiras:

\begin{abstract}
Mantém-se, assim, a já conhecida dança das cadeiras entre o órgão responsável pela comunicação governamental e a direção da empresa pública de comunicação - como já ocorreu com o (ainda) atual presidente da EBC Nelson Breve; com o antigo diretor geral Eduardo Castro; com o atual vice-presidente, Sylvio de Andrade; a atual secretária executiva Regina Silvério; e tantos outros antigos e atuais diretores, assessores e superintendentes da EBC, que fizeram o mesmo caminho, passando pela mestra catraca. Assim, uma vez mais, a Secom contribui para consolidar a já tão questionada, deslegitimada e promíscua relação entre comunicação pública e governo, num modelo em que não há espaço para o florescimento de uma real e imprescindível autonomia da empresa pública frente ao Planalto. ${ }^{152}$
\end{abstract}

Já o olho, em destaque, da nota do Intervozes chamava a atenção com palavras fortes: “A promíscua troca de integrantes entre a comunicação do Planalto e a direção da empresa compromete a autonomia da EBC e coloca em risco seu projeto original". Breve foi substituído por Américo Martins, que vinha respondendo pela diretoria-geral da empresa desde 10/02/2015, e tomou posse em 02 de setembro do mesmo ano. Martins não esquentaria muito a cadeira. Sete meses depois da posse deixou a presidência, entregando o cargo diretamente ao ministro da Secom, Edinho Silva. Comentários internos indicavam como causa da demissão de Martins as ingerências na programação. ${ }^{153}$ Em contato mantido por email com Américo Martins, em 3 de janeiro de 2017, ele manifestou como já comentamos, que não falaria sobre sua saída nem sobre o momento particular da $\mathrm{EBC}$, que naquele momento passava por grandes mudanças. "A empresa faz parte do meu passado e eu não acompanho mais o que acontece lá há muito tempo", escreveu. Américo informou que tinha voltado para a BBC, em Londres, e que havia assumido um cargo completamente diferente de tudo oque havia feito anteriormente. É agora Head of Global Parternships. “... Acho que

\footnotetext{
${ }^{151}$ Expressão usada em Brasília sobre as idas e vindas de dirigentes entre EBC e Secom.

152 INTERVOZES. Carta Capital. EBC: comunicação pública ou governamental? Disponível em: $<$ https://www.cartacapital.com.br/blogs/intervozes/ebc-comunicacao-publica-ou-governamental-8332.html $>$. Acesso em 23 jul. 2015.

${ }^{153}$ MELO, Débora, O que está por trás da saída do presidente da EBC. Carta Capital, São Paulo, 4 fev. 2016. $<$ http://www.cartacapital.com.br/sociedade/o-que-esta-por-tras-da-saida-do-presidente-da-ebc $>$.
} 
podemos traduzir como diretor de Parcerias Globais". (Nova mensagem recebida em 08 de Mai. 2017) ${ }^{154}$

Com as discussões e fóruns que resultaram na criação da $\mathrm{EBC}$, com seu conselho curador e todos os policies, esta instituição manteve a marca de ser uma empresa de governo, não de Estado. Financiada majoritariamente pelo Governo Federal, era o presidente da República quem nomeava seu dirigente, assim como os cargos de confiança passaram pelo crivo de partidos políticos da base de apoio ao governo. Nos primeiros tempos (2007), assumiram a direção o grupo ligado ao Ministério da Cultura e o grupo vindo da Secom ${ }^{155}$. Esses dois grupos partilharam os cargos mais altos da nova empresa ${ }^{156}$.

Três desses diretores eram vinculados ao MINC, e participaram das discussões para a criação de uma nova televisão pública no País, muito antes da elaboração dos documentos prévios que antecederam o I Fórum Nacional de TV's Públicas, que se realizou entre 26 e 28 de maio de 2007, em Brasília. Entre eles, Orlando Senna, que deixou a diretoria-geral da EBC, defendia desde 2003, quando ainda ocupava o cargo de secretário do Audiovisual do MINC, que essa televisão pública "democrática e participativa" deveria ficar vinculada ao Ministério da Cultura. Com ele concordavam as organizações e representantes da sociedade civil que participaram do I Fórum Nacional de TV's Públicas, em maio de 2007. ${ }^{157}$

As mudanças não ficaram restritas à diretoria. Em pouco mais de um ano abandonaram o Conselho Curador seis conselheiros, de um total de 15, entre eles seu presidente, o economista Luiz Gonzaga Beluzo. Os 15 representantes da sociedade civil do primeiro Conselho Curador haviam sido escolhidos pelo presidente da República, Luiz Inácio

\footnotetext{
${ }^{154}$ Mensagem Américo Martins: "Sou responsável por um departamento da BBC que produz conteúdo original em parceria com organizações externas à $\mathrm{BBC}$. Produzo projetos especiais, em qualquer mídia e em qualquer dos 42 idiomas nos quais a BBC opera, para transmissão nos nossos canais e em emissoras parceiras. Por exemplo: apenas dois meses depois de chegar, fiz um acordo com a Gates Foundation para a produção de duas séries sobre inovação no Sul da Ásia e na África ao longo de dois anos. Isso vai envolver quatro documentários para TV, cerca de 30 filmes digitais para nossas operações digitais em mais de 18 idiomas, debates, muita mídia social, etc. E já estou discutindo várias outras parcerias nesse momento, com universidades, o Instituto Nobel, etc. Um detalhe a BBC sempre tem controle editorial total final sobre tudo isso, sem interferências editorias dos parceiros. Como deve ser.

${ }^{155}$ SOUZA, Ana Paula. SANCHES, Pedro Alexandre. Do Estado ou do Governo. In Revista Carta Capital, São Paulo, Edição 14 mai. 2008.

${ }^{156}$ Mais mudanças aconteceriam meses depois, com a saída de alguns diretores (diretor Geral; de Rede e Relacionamento; de Programação e Conteúdos; e Administrativo).

${ }^{157}$ OTONDO, Teresa Montero. Televisão Pública - Para quem e para quê?.
} 
Lula da Silva. As mudanças nos primeiros dois anos da EBC atingiram também alguns cargos de gerência, contratados na fase de implantação da empresa.

A TV Brasil, que integra a EBC foi lançada em 2007, com um orçamento de R\$ 350 milhões anuais. Cinco anos depois, a instituição já tinha consumido "mais de R 2 bilhões em investimentos públicos", segundo informações do jornal Folha de S. Paulo (edição de 02/12/2012, p. E 9). Passados sete anos, o orçamento superava os R \$ 480 milhões anuais ${ }^{158}$. Conforme Relatório de Auditoria ${ }^{159}$, trabalhavam na empresa mais de 2.600 colaboradores. ${ }^{160}$ A EBC cresceu: sete rádios, a TV Brasil, a Agência Brasil, e, agora, a TV Brasil Internacional.

Em artigo publicado pelo O Estado de S. Paulo (22/09/2011, p.2), Eugenio Bucci lembra que a EBC "não é, na forma da lei, o que as democracias aprenderam a chamar de emissora pública". Ele justifica: "Nas emissoras públicas o executivo-chefe é escolhido por um conselho de representantes da sociedade. Nas estatais, quem escolhe o diretor é o governante da vez". A EBC, segundo Bucci, "está legalmente subordinada a uma autoridade que lhe é externa, e essa autoridade, a Secom ${ }^{161}$, tem por missão cuidar da imagem do governo federal". As movimentações nessas instituições também foram observadas por Carolina Matos $^{162}$, em um estudo que resultou no livro Mídia e Política na América Latina globalização, democracia e identidade. Matos ouviu profissionais que passaram por essas emissoras, como Tereza Cruvinel e Eugenio Bucci, que admitiram ser a autonomia e a independência total do governo uma tarefa difícil para essas emissoras, pois permanecem sujeitas aos constrangimentos polítisos (MATOS, 2013, p.228). Ainda se confunde público, estatal, com o governamental. Os movimentos por uma comunicação pública, isenta, independente e cidadãa, ${ }^{163}$ que culminaram com o I Fórum Nacional das TV's Públicas e a

\footnotetext{
${ }^{158}$ Dados atualizados até 31/10/2014. Disponível em

$<$ http://www.ebc.com.br/acessoainformacao/despesas/execucao-orcamentaria/>. Acesso em: 22 dez.2014.

${ }^{159}$ Disponível em: $<$ http://www.ebc.com.br/sites/default/files/relatorio_de_auditoria_n-16-2014.pdf $>$. Pag. 5. Acesso em: 22 dez. 2014.

${ }^{160}$ No Seminário Modelo Institucional da EBC, promovido pelo Conselho Curador (em 11 e 12/08/2015), em Brasília, o diretor vice-presidente de Gestão e Relacionamento, Sylvio Andrade, informou que o quadro era de 2.373 pessoas. $<$ http://www.ebc.com.br/institucional/sites/_institucional/files/documentofinalseminarioebc.pdf $>$.

161 Secretaria da Comunicação Social da Presidência da República.

${ }^{162} \mathrm{PhD}$ em Mídia e Comunicação na Política na Goldsmiths College, docente em tempo parcial no Government Department da Essex University.

${ }^{163}$ E este não é um sonho recente. Já no final do século passado as televisões públicas do mundo se reuniam anualmente em torno do International Public Televison Screening (INPUT), para analisar as estratégias dos
} 
criação da EBC, não conseguiram barrar as características de uma emissora governamental. Para agravar, a aprovação do impeachment representou mais um retrocesso: as ingerências governamentais se repetiram drasticamente em 2016.

Essas ocorrências acompanham a história das emissoras públicas. O que difere é que nos oito anos da EBC as trocas de gestores foram de acordo com a lei que a criou em 2007, ao final dos mandatos de quatro anos da diretoria, com uma exceção. O terceiro diretorpresidente nomeado por Dilma Roussef pediu seu afastamento sete meses depois. Américo Martins substituiu Nelson Breve, que se manteve no cargo por quatro anos, retornando ao antigo posto que ocupava na SECOM. Destaque-se que nesse período o Brasil foi governado por um mesmo partido, o PT, e com as mesmas alianças políticas. As mudanças e descontinuidades do passado ocorriam nos rodízios de poder, como neste pós-impeachment.

$\mathrm{A} \mathrm{EBC}$, que surgiu como uma nova proposta que encerraria o ciclo das televisões até então mantidas pelo Governo Federal e pelos Estados, vem repetindo o modelo das emissoras surgidas na ditadura, ou seja, opera sob regência dos governos. O cataclismo que se abateu na empresa em 2016 cresceu de intensidade dia-a-dia a partir de maio. Com o novo decreto, assistimos a desdobramentos que redundam em novas discussões em busca da TV pública defendida desde o século passado: uma nova Medida Provisória, a MP 774/2016, mudaria a empresa de comunicação pública federal.

\subsection{Entre parênteses: protagonismo e experiência de observação}

\subsubsection{Um relato pessoal}

Também fui protagonista de um processo de descontinuidade ao pedir exoneração do cargo de presidente da Fundação Cultural Piratini Rádio e Televisão Pública, uma fundação pública de direito privado. No final de 2002, em férias na cidade de Vitória, recebi um telefonema de um ex-colega de trabalho na Rádio Guaíba que assumiria no dia 1 de janeiro de 2003 o cargo de Secretário de Comunicações do Estado do Rio Grande do Sul. Era Ibsen Pinheiro, jornalista e ex-deputado federal, que tomaria posse no primeiro dia de janeiro, juntamente com o novo governador eleito, Germano Rigotto (PMDB). O motivo do

governos, sociedades, produtores e realizadores utilizavam para reivindicar a televisão pública como o lugar social de todos, como uma alternativa audiovisual de encontro da sociedade, de fomento dos direitos dos cidadãos, e de reconhecimento da pluralidade social que nos habita. (Cf. RINCON, 2002, 28) 
telefonema era o convite para assumir a presidência da Fundação Cultural Piratini-Rádio e Televisão FCPRTV. Já fazendo o Mestrado na ECA/USP, agradeci ao convite informando que não teria condições de deixar São Paulo naquele momento. As insistências vieram na sequência, incluindo outros portadores do convite, como o vice-governador Antônio Hohlfledt, também um ex-colega jornalista e professor universitário. Depois de várias negativas, fui convidada a ir a Porto Alegre no início de janeiro de 2003, para uma reunião com o já então secretário de Comunicações, Ibsen Pinheiro. Nessa reunião ouvi a proposta para assumir a presidência da FCPRTV, com a tarefa de transformar a FM Cultura e TVE em emissoras republicanas. A diretoria já estava definida: escolhas do secretário com aprovação do governador e resultado de indicações dos partidos da coligação. Dos indicados, muitos já haviam trabalhado comigo em atividades jornalísticas anteriores. Tinha perdido as referências com eles por estar em São Paulo havia 12 anos. Do secretário ouvi a garantia de que teria seu apoio em minha demanda pela autonomia na definição da programação e independência da instituição em relação a ingerências políticas. Em resposta ele afiançava que queria dar à Fundação a pluralidade - em suas palavras "republicana" ambiente que, segundo ele, não teria acontecido na gestão anterior.

No retorno a São Paulo, entrei num processo de reflexão, tentando juntar as peças antes de tomar a decisão final. Um fato destacado no convite era eu não ter nenhuma vinculação política. Na opinião do secretário, a escolha de meu nome era técnica; buscaram a profissional que 15 anos antes tinha colocado a estatal FM Cultura no ar no Rio Grande do Sul, como a primeira diretora, entre outros empreendimentos realizados em São Paulo. No processo reflexivo, contatei amigos residentes em Porto Alegre e através destes cheguei ao presidente do Conselho Deliberativo da Fundação Cultural Piratini Rádio e Televisão, Daniel Hersz, "cidadão eleito" ${ }^{164}$ do Conselho e estudioso da televisão pública. Esse contato foi fundamental, mais adiante, para a minha tomada de decisão. Hersz estimulou-me a aceitar, manifestando sua expectativa positiva com a possibilidade de eu vir a presidir a Fundação, lembrando o trabalho que eu havia realizado como diretora fundadora da FM Cultura, 15 anos antes, com autonomia e independência garantidas pelo governador Pedro Simon, também um governo do PMDB. Para Hersz, aquela experiência poderia ser repetida com a chance de transformarmos, com apoio do Conselho, a TVE-RS em uma verdadeira Televisão Pública.

\footnotetext{
${ }^{164}$ O Conselho Deliberativo era composto por 20 (vinte) membros natos (representantes de várias entidades e orgãos governamentais) e seis (06) membros eleitos, conforme o Art. $3^{\circ}$ da Lei $n^{\circ} 10.536$ de 08/08/1995, que dispõe sobre o Conselho Deliberativo da FCPRTV.
} 
Recebi do presidente vários estudos sobre a programação desenvolvidos pelo Conselho, contendo avaliações da programação, diretrizes para as emissoras, entre outros relatórios ${ }^{165}$. Debrucei-me sobre todos esses documentos, empreendendo uma verdadeira imersão para entender, sob o ponto de vista do Conselho Deliberativo, o que era a FCPRTV, como atuava e a relação existente entre a Direção Executiva e este colegiado. Essas leituras apontaram a existência de problemas na relação entre os dois órgãos administradores - a diretoria executiva e o Conselho. Custei a aceitar o convite. Nesse periodo, foi nomeado um presidente interino. Depois de muito refletir e de ouvir a garantia de que teríamos autonomia e respaldo para desenvolver um trabalho isento e independente, considerando-se as várias representações políticas que operavam no novo governo, aceitei o desafio, certa de que seria possível praticar a sonhada televisão pública. Já tinha o lema para apresentar ao governador caso surgisse uma oportunidade para endossar a proposta das emissoras republicanas. Que ele mudasse os verbos que os governadores anteriores conjugaram para interferir na TVE-RS: ao invés de "Eu pago, eu mando" que ele optasse por "Eu pago, eu concedo". A parceria com o Conselho Deliberativo foi fundamental para o periodo em que estive à frente da FCPRTV. E ao seu presidente, Daniel Hersz, meu reconhecimento póstumo pelo apoio e conselhos recebidos ao longo daquele convívio.

O projeto, como tantos outros iniciados em emissoras públicas, também não teve continuidade. Um ano e quatro meses depois de assumir, solicitei minha exoneração por temer que a partir dali as interferências seriam inevitáveis. Aproximava-nos de um período eleitoral, e o secretário de Comunicações que havia me formulado o convite e que até então manteve a palavra de blindar e instituição contra as tentativas de interferência deixou o governo. A Secretaria de Comunicações foi extinta e a FCPRTV passou a responder diretamente à Coordenadoria de Comunicação Social, vinculada ao Gabinete Civil do Governador. Pressenti, como Edgard Roquette-Pinto ao não permitir que a Rádio MEC ficasse sob a coordenação do Departamento de Imprensa e Propaganda, que as ingerências políticas chegariam inevitavelmente. Comuniquei a todos os funcionários que estava deixando a instituição, expliquei os motivos e conclamei para que se organizassem em defesa da Fundação, afinal, eles eram os "estabelecidos" e ali estavam como resistentes incansáveis sempre na expectativa de que a gestão seguinte faria a esperada televisão pública.

\footnotetext{
${ }^{165}$ Esses documentos integram os anexos da Dissertação de Mestrado - Produção de Sentidos, Perfil de uma experiência, defendida em 2005, na ECA/USP, sob orientação da Profa. Dra. Terezinha Fátima Tagé Dias Fernandes. Contei com a co-orientação também da Profa. Dra. Cremilda Medina.
} 
Voltei a São Paulo com a determinação de dedicar meu tempo ao projeto de pesquisa para o Mestrado, refletir e tentar entender o que havia vivido como protagonista, que também ocorria com outras instituições similares. Era um tema que deveria estar na agenda da academia. Continuo achando hoje, passados mais de uma década, e com uma nova experiência, o testemunho de criação da Empresa Brasil de Comunicação, que chegou com o propósito de avançar no projeto de uma televisão pública para o País. E agora, contando com aquilo que sempre foi mínimo - recursos orçamentários - sofreu mais um revés em 2016.

\subsubsection{Outro relato pessoal}

Voltando um pouco no tempo, a primeira experiência com emissora pública e que me possibilitou os contatos com o SINRED aconteceu em 1988, quando fui convidada para colocar no ar uma emissora de rádio em Frequência Modulada (FM), em Porto Alegre. O convite partiu de Alfredo Fedrizzi, presidente da Fundação Cultural Piratini Rádio e Televisão (FCRTV), apoiado por Rosa Crescente, Diretora Adminsitrativa da TVE-RS, e de Luís Eduardo Crescente (in memorian), diretor de Programacão. Esse convite aconteceu no início de novembro daquele ano, quando eu estava no Diário do Sul, jornal da Gazeta Mercantil, que passava por sérias dificuldades e que acabou fechando. Aceitei o convite e fui contratada no dia 17 de novembro de 1988.

Assumia ali um desafio "enorme”. A concessão para operação de uma rádio FM pela FCPRTV venceria em fevereiro de 1989, pouco mais de dois meses depois, sob pena de “caducar a concessão”. Todas as prorrogações possiveis já tinham sido vencidas. Foram dois meses de intenso trabalho, desde a contratação de pessoal, montagem do projeto, definição da programação e ajutes do projeto técnico que estava previsto para operar como uma rádio com perfil de locutor apresentador, e organização de uma discoteca.

Não vou detalhar esse trabalho, mas destacar algumas considerações que me trazem a certeza de que ali fizemos uma emissora realimente pública. Como a contratação para uma Fundacão Pública de Direito Privado, esse era ordenamento jurídico da FCPRTV, deveria ser por concurso público, o prazo de dois meses que tínhamos inviabilizava a realizacão de concurso e, por consequência, a criação da rádio. Então solicitamos uma reunião com Conselho de Governo que reunia diversos secretários, para que autorizassem a contratação em caráter emergencial de todos os profissionais. Nos debruçamos nas legislações dos radialistas e jornalistas e procuramos fazer essas contratracões com a maior lisura e 
isenção. Para a contratação de técnicos, selecionamos os candidatos através de uma bolsa de emprego do Sindicato dos Radialistas. Para a atividade de programador musical, buscamos perfis de profissionais que tivessem formação musical superior, devido às características da programação que incluía diferentes gêneros, como música de concerto, música popular brasileira e internacional e jazz. Para preencher os cargos de jornalistas (redator, repórter e editor) selecionamos jornalistas que estavam desempregados com o fechamento do jornal Diário do Sul.

Antes, com atorização da direção e da Secretaria de Cultura, à qual a FCPRTVC estava vinculada, fizemos uma pesquisa para entender o que desejava o público de Porto Alegre (a rádio (FM) tinha alcance limitado à capital e cidades vizinhas). Selecionamos alguns formadores de opinião para também ouvirmos, entre eles o escritor Luiz Fernando Verissimo, e também intelectuais, professores e profissionais liberais, para discutirmos uma perspectiva de programação. Além disso, fomos autorizados - Rosa Crescente (diretora administrativa) e eu - a visitar algumas rádios que tinham o perfil do que se pretendia também fazer. As visitas incluíram a Rádio Cultura FM (da Fundacão Padre Anchieta), e a Rádio Eldorado FM, de São Paulo, e as rádios Jornal do Brasil e MEC, no Rio de Janeiro.

De posse de todas essas informações me debrucei no projeto, já com a ajuda da equipe contratada em meados de janeiro. Organizamos um curso intensivo para preparar a maioria desses profissionais que até então tinham experiência em jornal impresso, para entenderem o processo de uma rádio, com sua linguagem especifica, com sonoras, entrevistas ao vivo e gravadas, música clássica que dividia organizadamente os espaços da grade com a música popular (brasileira e itnernacional) e o jazz. Para isso, levamos para Porto Alegre Taís Almeida, então diretora da Cultura FM, de São Paulo, que reunia experiência com uma emissora segmentada para a música de concerto e que vinha com um trabalho bastante elogiado pelos pares e pela audência.

Com essas providências, no dia 4 de fevereiro, a rádio entrava no ar em caráter experimental, como determinava a legislação, no prazo previsto. Quatro horas depois recebemos a primeira ligação de um ouvinte querendo saber que rádio "maravilhosa" era aquela que ele tinha acabado de descobrir. A programação, segundo este ouvinte, dava a sensação de estar em casa ouvindo os seus discos. A partir de ali, os ouvintes foram os maiores colaboradores com doação de discos (a discoteca era formada inicialmente por nossos discos - todos os profissionais selecionaram seus LPs devidamente identificados para sempre devoldidos depois de formada a discoteca da emissora). Os CDs foram entrando na medida em que liberavam recursos, sempre escassos, além das doações que passaram a ser 
rotineiras. Os ouvintes doavam os LPs à medida que faziam as substituições de suas discotecas para CDs. E as compras da emissora passaram a focar também nessa mídia, que chegava com força.

No finalzinho de dezembro de 1988, conseguimos alguns recursos da FCPRTV, sobra do orçamento daquele ano, para fazermos algumas aquisições de discos. Convidei os novos programadores que ainda seriam contratados, juntamente com o professor Flavio Oliveira, que colaborou muito no projeto trazendo sua experiência na Rádio Universidade ${ }^{166}$ da UFRGS, então a única emissora a veicular música de concerto em Porto Alegre. Conseguimos nessa primeira compra adquirir 100 LPs, entre música popular e clássica (ou de concerto).

O lançamento oficial da emissora aconteceu no dia 20 de março de 1989, com a presença do governador, autoridades, intelectuais, músicos, artistas e os profissionais. A rádio já era então reconhecida como um projeto que orgulhava não só a equipe como os ouvintes, os verdadeiros donos como contribuintes.

\subsection{O caso de São Paulo}

A TV Cultura de São Paulo, tida como bom exemplo por ter sido criada "como uma entidade de direito privado, sem finalidade de lucro, financiada pelo governo do Estado de São Paulo, mas constituída como uma instituição autônoma e independente...” (OTONDO, 2012), passou por situações de conflito e dificuldades para se consolidar como uma emissora independente. "Da sua compra pelo Estado, cercada de desconfianças, passamos pelo projeto elitista de levar erudição ao "povo inculto" e de, ao mesmo tempo, atender às elites com programas de "bom gosto" chegamos à constatação da existência de visões divergentes entre direção e produção, introduzindo a ideia da presença do conflito interior de um meio de comunicação que se pretendia homogêneo". A constatação de Lalo Leal foi feita em 1988.

Passados mais de 20 anos da avaliação do professor, observamos que a TV Cultura, embora promissora nos anos 1990, não teve o projeto consolidado. Para Beth Carmona, diretora da emissora naquela época, a TV Cultura "praticou efetivamente o conceito de TV pública, deixando de lado o modelo professoral didático”. Esse foi um momento decisivo,

\footnotetext{
${ }^{166}$ A Rádio Universidade era uma emissora AM. A FM Cultura, que chegava, era uma FM, ou seja, transmitia em Frequencia Modulada, o que prometia uma melhor qualidade sonora, principalmente para as músicas de orquestra/concerto.
} 
segundo a ex-diretora, não só pelo financiamento da TV pelo Governo do Estado de São Paulo, como também pela parceria com a iniciativa privada num sistema de incentivo cultural. Carmona enumera ainda "a dedicação, a consciência e o talento de uma equipe apaixonada" que garantiu a "marcante e duradora experiência da TV infantil nacional, como os programas Rá-Tim-Bum, Mundo da Lua, Cocoricó, X-Tudo, entre outros. Na grade de programação estava uma combinação de programas produzidos no Brasil, com outros selecionados em países como Alemanha, Inglaterra, Países do Leste Europeu, Estados Unidos, Austrália, transmitidos em horários estratégicos. Essa combinação, segundo Beth, deu ao público quantidade, qualidade e uma real dimensão de conversa, "ou seja, uma programação que respondia aos anseios dos telespectadores". A emissora chegou nesse período a dois dígitos de audiência (CARMONA, Beth, $2006^{167}$ ).

E nos anos 2000, voltamos a testemunhar conflitos na mudança de gestão das emissoras públicas, como a ocorrida na troca de presidentes da própria TV Cultura São Paulo, em 2007, com a saída de Marcos Mendonça, e a entrada de Paulo Markun. Este também não ficaria muito tempo no cargo. Foi substituído pelo economista João Sayad, que fora secretário de Cultura do Estado de São Paulo, formulador do convite para que Markun se candidatasse ao cargo. O grande problema é que as mudanças não ficam restritas aos cargos da cúpula. Alcançam áreas estratégicas na produção, interferem na programação e faz-se perder talentos formados internamente com a visão de que uma televisão educativa é um serviço público voltado ao cidadão e não ao consumidor.

Conforme os estatutos da TVC de São Paulo, a mudança do cargo de presidente não é coincidente com a mudança do ocupante do cargo de governador. Mas isso não impede, nem jamais impediu, as ingerências, de "caráter apolítico"168 , mesmo contando com um Conselho Curador como "principal barreira institucional às investidas do Estado e da iniciativa privada sobre as emissoras"169, já que, segundo Laurindo Lalo Leal, "nessa tarefa, o Conselho tem como instrumento legal o fato de a Fundação ser uma instituição pública de direito privado, o que impede a ingerência em sua gestão". Entretanto, são várias as limitações do Conselho,

\footnotetext{
${ }^{167}$ CARMONA, Beth. A marca da TV pública. In I Forum Nacional de TV’S Públicas. Diagnóstico do Campo Público. Ministério da Cultura, Brasília. 2006.

${ }^{168}$ LEAL FILHO, Laurindo. Atrás das Câmeras - relações entre cultura, estado e televisão. Summus, São Paulo, 1988 , p.60.

${ }^{169}$ LEAL FILHO, Laurindo. A TV Pública. In BUCCI, Eugênio (org). “A TV aos 50 - Criticando a televisão brasileira no seu cinquentenário. Editora Fundação Perseu Abramo, São Paulo, 2003. p.159.
} 
inclusive o fato de existirem nele cadeiras vitalícias e de haver presença excessiva de representantes de órgãos públicos e municipais". ${ }^{170}$

\subsection{BBC - nosso modelo também sofre revezes}

A pioneira $\mathrm{BBC}$, referência quando se fala em televisão pública, também enfrentou momentos de crise que forçaram mudanças em seu comando. Uma delas aconteceu em novembro de 2012, que resultou na mudança do diretor-geral. Foram dois escândalos de caráter jornalístico em menos de um mês. ${ }^{171}$ A reação foi instantânea. O presidente da Fundação BBC, órgão independente responsável pela orientação estratégica da emissora britânica, Chris Patten, afirmou na oportunidade que a rede passaria "por uma reestruturação para assegurar sua credibilidade". ${ }^{172}$ Dez dias depois, foi efetivada a troca de comando. O escolhido (pela Fundação) para ocupar a direção-geral foi Tony Hall, que ocupava o cargo de executivo-chefe da Royal Opera House. Hall trabalhou na emissora durante 28 anos, tendo exercido a chefia do departamento de jornalismo entre 1996 e 2001. A escolha foi estratégica, considerando-se que a origem do conflito foi na área jornalística, e Hall, pelo tempo de trabalho na instituição, é conhecedor dos códigos de ética e da missão da emissora. Essa foi a resposta da Fundação para garantir ao público a credibilidade cultivada ao longo de sua história. ${ }^{173}$

Em 2017, o panorama seria bastante positivo, conforme depoimento de Américo Martins ex-presidente da EBC a esta pesquisadora em 3 de janeiro de 2017. Martins que desde 2016 trabalha na emissora em Londres, manifestou em mensagem de email sua admiração pela $\mathrm{BBC}$ onde já tinha integrado o quadro de profissionais em outros momentos. Quando perguntei se achava que a TV pública tinha fracassado, respondeu dando como exemplo a televisão britânica. Reproduzo sua avaliação:

\footnotetext{
${ }^{170}$ Ibid, p. 160.

${ }^{171}$ A veiculação de uma reportagem em que um homem afirmava ter sofrido abuso, quando criança, de um político. A emissora não revelou o nome, mas informações que circularam pela internet apontaram o exintegrante da Casa dos Lordes Alistair McAlpine, que negou envolvimento. O acusador acabou se retratando e restou ao diretor geral, George Entwistle, pedir desculpas reconhecendo que a reportagem não deveria ter sido exibida. Um mês antes, em outubro, vieram à tona acusações de que o apresentador Jimmy Savile, morto em 2011, abusou de crianças durante 40 anos. Dois escândalos envolvendo pedofilia num curto espaço de tempo.

${ }^{172}$ Fundação BBC diz que emissora vai mudar. Em Folha de S. Paulo, 12/11/2012. p. A18.

173 Conforme Tereza Otondo a origem das crises nessas instituições sempre nascem dentro do Jornalismo, apesar dos princípios editoriais que regem a EBC, exemplares e inspiradores para o modelo brasileiro.
} 
não acho que a TV pública fracassou, de forma nenhuma. É claro que algumas estão em crise, mas se você comparar com as empresas privadas de comunicação... Não sei se estão melhores não, muito pelo contrário. E, no caso específico da $\mathrm{BBC}$, acabamos de anunciar novos investimentos em mais 10 línguas e estamos fazendo uma grande transformação nas nossas operações, deixando a empresa cada vez mais moderna e forte. Não vejo essa crise aqui, não. A BBC continua sendo a maior empresa de comunicação da Europa, líder no Reino Unido e com novos investimentos internacionais. Não vejo crise nisso. Agora, como todas as empresas da área (privadas, públicas, estatais, etc), está tendo que se adaptar às novas condições do Mercado --mas esse é um processo que vem de algum tempo e hoje já mostra alguns sinais muito bons. (MARTINS, Américo, 2017)

A aclamada TVE, televisão pública espanhola, também enfrenta uma crise de gestão, como noticiou em 07 de maio de 2017, o site do jornal El Pais ${ }^{174}$. Em reportagem com o título El fin del trienio negro en RTVE- La falta de independencia informativa, la caída de audiencia y los contratos con productoras marcan la etapa de Sánchez, descreve o olho da matéria. A reportagem informa que o mandato do presidente da RTVE José Antonio Sánchez chega ao fim com resultados negativos. Sobre o atual presidente, a reportagem faz um balanço negativo:

Su etapa en la corporación estatal está marcada a llevar a TVE a las cotas de audiencia más bajas de su historia. Además, los informativos han adolecido de falta de pluralismo e independencia y la polémica ha salpicado los contratos con las productoras privadas, que han asumido prácticamente todos los formatos de entretenimiento. TVE no ha sabido tampoco adaptarse a los nuevos consumos digitales y la gestión económica se ha saldado con déficit. (Grifo do jornal)

$\mathrm{Na}$ mesma semana em que foi publicada a reportagem, estava em discussão no Congresso a reforma da lei que nomeia o presidente da RTVE. Seu sucessor será nomeado por uma maioria de dois terços dos deputados, o que fica a cargo dos grupos de parlamentares que devem pactuar a escolha do candidato.

No Brasil, uma década depois da criação da EBC constata-se que a televisão chamada "pública" no seu sentido mais complexo, como nos ensinam pesquisadores como Omar

174 GOMEZ, Rosario. El fin del trienio negro en RTVE. El Pais. Disponível em: $<$ http://cultura.elpais.com/cultura/2017/05/06/television/1494084)124_205545 . Acesso em 7 mai. 2017. 
Rincón, Jesus Martín-Barbero entre tantos outros, ainda não chegou. Teresa Otondo, que lançou seu livro Televisão Pública - para quem e para quê?, em 2012, destaca:

“a TV Brasil, da Empresa Brasileira (Brasil) de Comunicação (...) têm a meu ver um estatuto ainda ambíguo nesse contexto: esta é pública por seus objetivos, mas estatal por sua origem e estrutura ainda que tenha integrado representantes da sociedade civil em seu conselho". (OTONDO, Teresa, 2012, p. 63) ${ }^{175}$

Em entrevista aos repórteres Ana Paula Souza e Pedro Alexandre Sanches, da revista Carta Capital, (edição14/05/2008), Beth Carmona ex-diretora da TV Cultura de São Paulo e ex-presidente da TVE do Rio de Janeiro (ACERP- como já observado) no primeiro mandato do presidente Lula, fez considerações em 2008 sobre o sentido de uma TV pública no País. Nome ligado aos maiores sucessos de uma emissora pública brasileira, o Castelo Rá-Tim-Bum (TV Cultura) e Um Menino Muito Maluquinho (TVE Rio), que conquistou premiações internacionais, e passagens ainda pela Disney e Fox Kids, Beth deixou a emissora federal em 2007. Questionada sobre sua saída das duas emissoras, em momentos de "grandes mudanças de fundo político", Beth disse:

"É difícil falar de tevê pública neste momento. A meu ver, nos dois casos, construímos alguma coisa que teve um problema de descontinuidade. Parece que algumas lições aprendidas e alguns percursos feitos não foram considerados. Não sei se é meu destino, mas me cansei um pouco dessa eterna construção. Acho que já contribui bastante para essa causa."

Adiante, Carmona reconheceu que o Brasil já teve algumas experiências e não conseguiu consolidá-las. Hoje há um orçamento definido, e uma nova lei que criou um Comitê Editorial e de Programação ${ }^{176}$, com atribuições bastante diferentes das previstas no Conselho Curador originalmente para a Empresa Brasil de Comunicação, como propôs o relatório do Senador Laiser Martins. Beth Carmona parecia pressentir que mudanças mais

\footnotetext{
${ }^{175}$ E agora, cerca de cinco anos depois da publicação do livro de Teresa Otondo, menos ainda com a aprovação pelo Senado Federal e Câmara dos Deputados, da Medida Provisória 744/2016, que alterou Lei de criação da EBC (Lei 11.652/2011), com a extinção do Conselho Curador, saída da Secom para o Gabinete Civil, entre outras alterações.

${ }^{176}$ POSSEBON, Samuel. Relator propõe que EBC tenha um Comitê Editorial e dá poderes ao Senado sobre empresa. Tela Viva News. 6 dez. 2016, $<$ http://convergecom.com.br/teletime/06/12/2016/relator-propoe-queebc-tenha-um-comite-editorial-e-da-poderes-ao-senado-sobre-empresa/?noticiario=TL $>$. Acesso em 15 dez. 2016.
} 
drásticas chegariam, como lá atrás Edgard Roquette-Pinto ao resistir em sua posição de doar a Rádio MEC ao Ministério da Educação e Saúde e não ao Departamento de Imprensa e Propaganda (DIP).

Como abordado anteriormente, no Seminário Modelo Institucional da EBC: balanço e perspectiva, realizado em agosto de 2015 , em Brasília, em seu documento final ${ }^{177}$, dividido por eixos ${ }^{178}$, vê-se que os debates levantaram as questões da autonomia e a vinculação com a Secom como pontos nevrálgicos. Temas que agora se intensificam com a vinculação da Secom à Casa Civil. Ou seja, a proximidade com a presidência da República e sua apropriação pelo governo de plantão fica assim mais latente.

Essas questões me reportam ao escritor e jornalista Sinval Medina em seu texto $O$ gigante sob suspeita ${ }^{179}$, escrito em 1996. Sinval propôs uma reflexão sobre as incertezas que cercavam o modelo de organização política "que convencionamos chamar de Estado Nacional". O escritor traça um "esboço do Estado como um aparato histórico das tempestades de um curto momento da trajetória humana", e enfatiza que ele reflete, em sua concepção, o paradigma intelectual da modernidade. Faz um retrospecto histórico sobre a noção de Estado a partir da Paz de Vestfália (1648) e sugere refletir sob novo angulo:

\begin{abstract}
Sugiro que vejamos o Estado moderno não como produto superior do espírito humano, e portanto, como a forma última de regulação social, mas como um aparato desenvolvido por certas sociedades para responder a determinados desafios que se colocaram ao longo de sua trajetória no tempo e no espaço (MEDINA, Sinval, 1996, p.352)
\end{abstract}

Numa conversa posterior (junho de 2017) com o escritor sobre seu texto de 1996, ele se propôs a fazer novas reflexões, com uma "leitura" do presente aflitivo. Sinval Medina cita o artigo de Marco Aurélio Nogueira (OESP, 27/05/2917, p.2) que define esse momento como "a crise estrutural da modernidade capitalista". Crise essa que, segundo Nogueira, citado por Medina, altera os relacionamentos entre grupos, classes e pessoas, o modelo de produção e o trabalho". (Cf. NOGUEIRA, OESP. 27/05/2017). Para Medina, "as fraturas do mundo

\footnotetext{
177 Disponível em: $\quad<$ http://www.ebc.com.br/institucional/conselho-curador/noticias/2015/10/publicadodocumento-final-do-seminario-modelo-institucional-da-ebc>. Acesso em jun. 2016.

${ }^{178}$ Os eixos foram: Autonomia e Vinculação; Financiamento e Sustentabilidade; e Gestão de Conteúdo e Participação Social;

${ }^{179}$ MEDINA, Sinval. O Gigante sob suspeita. In A Agonia do Leviatã: a crise do Estado moderno. MEDINA, Cremilda, e GRECO, Milton (orgs). Novo Pacto da Ciência 5. São Paulo: ECA/USP/CNPq. 1996.
} 
contemporâneo estão aí, expostas aos olhos de quem quiser ver. Nesse quadro de crise generalizada, não se pode esperar que os estados nacionais escapem incólumes. As antigas estruturas balançam, agitadas pela tempestade". Entre essas, situo as organizações de comunicação pública como as aqui estudadas. No entanto, Medina vê perspectivas de saídas em meio ao turbilhão contemporâneo. Essas estruturas que balançam

podem ser revitalizadas por políticas reformistas, ou então condenadas à ruína e de seus escombros surgirão regras institucionais completamente novas, não necessariamente mais justas, humanas e solidárias. Em síntese, o mundo tal qual o conhecemos, produto da Revolução Industrial, da Razão, da Ciência, da democracia liberal, dos ideais de justiça social poderá sair da UTI e ressurgir sob novas luzes, ou estamos a caminho de dias mais escuros? O futuro da humanidade é a distopia em vez da utopia? Essa é a pergunta para a qual ainda não temos respostas, no entanto, é a ideia de que o estado nacional é uma construção histórica e não um ente atemporal. Os rumos da história contemporânea, com suas tremendas transformações sociais, econômicas, geopolíticas estão sepultando o estado nacional tal como o conhecemos? Quem viver, verá." (MEDINA, Sinval. Informação verbal e texto de reflexão)

Esse é o desafio de reflexão que me propôs o escritor Sinval Medina. Não ficam incólumes as instituições de comunicações em todos os níveis - das privadas às públicas -, estas, por serem consideradas também "governamentais" pelos seus dirigentes, sofrem com os olhos vendados e o apagamento às informações inconvenientes. "Nessas circunstâncias, não podemos imaginar que tal aparato permaneça imune às borrascas (ou até mesmo aos naufrágios) da História" (MEDINA, Sinval, 1996). 


\section{Produção de sentidos na TV Pública: Educação? Cultura? Entretenimento?}

Cultura é o conjunto das práticas, das técnicas, dos símbolos e dos valores que se devem transmitir às novas gerações para garantir a reprodução de um estado de coexistência social. A educação é o momento institucional marcado do processo. (BOSI, Alfredo, 1992, p. 16) ${ }^{180}$

No se puede entender lo que está passando en las sociedades sin compreender lo que está pasando en los fenómenos de migración y las conexiones que la gente vive con las culturas outras y sus culturas propias. Habitamos una sociedade estallada en tiempos y espacios. (BARBERO, 2015, pp.13-14)

As TV públicas construíram sua trajetória no binômio educação e cultura, acompanhado do complemento - para formar cidadania. Assim se apresentavam, em suas missões e compromissos, as emissoras vinculadas aos Estados, Governo Federal e Fundações, incluindo a TVE Brasil ${ }^{181}$, gerida pela Associação de Comunicação Educativa Roquette-Pinto (ACERP), que daria origem, em 2007, à TV Brasil/EBC, junto com a Radiobrás, como já assinalamos. Esse conjunto de palavras também estava impresso nos Princípios Éticos da Televisão Pública Brasileira, documento firmado em abril de 1999, pelas emissoras associadas à ABEPEC - Associação Brasileira de Emissoras Públicas Educativas e Culturais, em encontro realizado no Rio de Janeiro. O documento abria com um parágrafo em destaque para afirmar o compromisso de suas associadas: “As emissoras de televisão educativa de todo o país criaram a ABEPEC - Associação Brasileira das Emissoras Públicas Educativas e Culturais, assumindo compromissos em torno de uma programação ética, de qualidade, voltada para os interesses da sociedade e do cidadão".

$\mathrm{Na}$ sequência, o texto enfatizava que essas emissoras, que integravam a rede pública de televisão, "reafirmaram, no ato de criação da entidade, a responsabilidade de prestar serviços públicos de educação, cultura, informação e entretenimento, sempre com o objetivo de promover cidadania e ser uma alternativa eficaz à programação da televisão

\footnotetext{
$180 \quad$ Disponível em: $\quad<$ http://www.iphi.org.br/sites/filosofia brasil/Alfredo Bosi Dial\%E9tica da Coloniza\%E7\%E3o.pdf > . Acesso em 24 abr. 2017

${ }^{181}$ A ACERP mantinha, quando foi criada a EBC, contrato de gestão com a SECOM, como já informado em capítulos anteriores.
} 
convencional". Lá estava impressa a sequencia de palavras com a intenção de caracterizar a programação das emissoras nascidas, muitas delas, no período da ditadura. Esse documento da ABEPEC foi um estímulo para que as emissoras se envolvessem na ideia de trabalhar em conjunto pela qualidade da programação que apresentavam a seus públicos, com um destaque: “o respeito aos direitos do cidadão, com atenção a especial para a criança e o adolescente, é o princípio número um a ser observado" (ABEPEC, 2003) $)^{182}$.

Trago citações anteriores da ABEPEC, para refletir, a partir delas, como esses termos eram percebidos no interior das instituições, onde se elaboravam as referidas programações. Lembro aqui um fato, quando dirigia a Fundação Cultural Piratini Rádio e Televisão (FCPRTV - mantenedora da TVE- RS e Rádio FM Cultura), por sugestão da Profa. Dra. Cremilda Medina, solicitei aos profissionais que trabalhavam nas áreas de produção, para que escrevessem sobre o que entendiam por cultura. A solicitação não teve caráter obrigatório e dos cerca de 30 produtores naquelas condições, 14 atenderam ao pedido. Na divisão do trabalho na FCPRTV, o quadro funcional era distribuído pelas diretorias de Programação, Jornalismo e Rádio, além da Técnica. Do Departamento de Jornalismo, a resposta foi inexpressiva. Na época, conclui que ali não houve o empenho dos chefes intermediários para que estimulassem a participação, diferentemente do que aconteceu na área de programação, “onde o gerente não só respondeu, como estimulou a participação de todos os produtores de seu núcleo". Pelas respostas, foi possível perceber que, para uma maioria, produção cultural representava na programação os programas dedicados a eventos voltados à música, nos distintos gêneros, ao teatro, literatura entre outros.

Os conceitos apresentados reproduziam descrições teóricas, sem fazer alusão à dinâmica do trabalho na televisão como criação cultural. Para eles, um atentado em Madri, como o ocorrido naquele período, em 11 de março de $2004^{183}$, por exemplo, não era pauta para o programa considerado uma revista cultural, chamado Estação Cultura, que ia ao ar por

\footnotetext{
${ }^{182}$ Abro um parêntese para lembrar a origem das emissoras que nasceram com o nome educativas. Surgem mais de uma década depois das TVs comerciais, que tiveram sua estreia nos anos 1950. A primeira foi a TV Universitária de Pernambuco, em 1967. Nos anos seguintes brotam mais pelos estados. No período de 1967 a 1974, anos áureos da Ditadura, foram criadas nove emissoras educativas, com vinculações distintas. O impulso para isso, foi o Programa Nacional de Teleducação, criado pelo Ministério da Educação, com o objetivo de coordenar as atividades de teleducação no País (FRADKIN, Alexandre, 2003 ${ }^{182}$ ). Desse período, ficaram os nomes na maioria delas, algumas exceções como a TV Cultura, embora reconhecidas como a 'mídia televisiva voltada para a educação e a cultura', as chamadas TVs públicas, que no Brasil acabaram sendo acomodadas sobre o impreciso e vago rótulo de emissoras educativas e culturais" (CARRATO, Ângela, s/d) ${ }^{182}$. (Grifo nosso). ${ }^{183}$ Os atentados de 11 de março de 2004, também conhecidos como 11-M, foram atentados terroristas que ocorreram quase simultaneamente, contra o sistema de trens suburbanos em Madri, Espanha.
} 
volta das $12 \mathrm{~h}$, pouco depois daquele acontecimento que ocupou a atenção e o espaço de rádio e televisão de todo o mundo. Questionei os produtores porque o tema não havia sido tratado pelo programa e recebi a seguinte resposta: "O assunto era de interesse jornalístico e deveria estar no telejornal”. Essa resposta mereceu reflexões e debates nos encontros semanais (que hoje eu chamaria de "laboratório", inspirada por Cremilda Medina) nomeados Seminário de Qualificação Profissional da TVE, ${ }^{184}$ que promovemos ao longo de três meses reunindo todos os profissionais das duas emissoras. Esse seminário teve como encerramento especial uma aula-conferência ministrada pela Profa. Medina ${ }^{185}$.

Repeti, mais tarde, a experiência de refletir sobre mediação, cultura, e produção de sentidos com os profissionais das Rádios MEC - AM e FM -, quando fui responsável pela gerência executiva das duas emissoras, então vinculadas à ACERP. Também desta vez contei com a Profa. Dra. Cremilda Medina para despertar os produtores para suas responsabilidades como mediadores das narrativas da contemporaneidade. Ao tratar da expansão da audiência referindo-se a uma afirmação da então presidente da ACERP, Beth Carmona, no livro TVE Brasil - Cenas de uma História (MILANEZ, 2007) -, Cremilda afirmou que "a potência de expansão de uma mídia contemporânea é explosiva e, diante desta explosão da mídia, surgem os compromissos sociais de quem prepara, de quem produz, ou seja, do comunicador social”. Inspirada pelos presentes que representavam as diferentes áreas da emissora, a professora lembrou as várias atividades que tem o comunicador social: "Pela divisão do trabalho, aqui dentro e por este auditório, vários de vocês são aglomerados em um setor, outros em outros, etc. Isto é a divisão do trabalho. Mas o espírito da coisa é que todos são produtores culturais, todos são comunicadores sociais”. Esta era a provocação que se esperava para tirar do casulo aqueles profissionais acomodados ao longo dos tempos a repetir rotineira e autonomamente um trabalho que deveria a cada dia inovar e surpreender. (Grifo nosso) Era o que esperávamos naquela gestão - tanto nas rádios quanto na televisão. Também foi oportuno um comentário de Cremilda Medina ao se referir a uma frase de Beth Carmona no mesmo livro: "a marca da TV educativa só é possível por meio do debate entre os profissionais, da observação do público, da experimentação de fórmulas, da formação de jovens diretores, programadores e

\footnotetext{
${ }^{184}$ Ao longo dos três meses, em dois encontros semanais, nos dois turnos para permitir a participação de todos os funcionários, o seminário provocou uma revisão de conhecimentos profissionais e a atualização de procedimentos. (MILANEZ, 2005, p. 97)

${ }^{185}$ A íntegra dessa palestra constou dos anexos da Dissertação Produção de Sentidos na TV Pública: perfil de uma experiência (ECA/USP, 2005).
} 
produtores com espírito público". Foi o elo para Medina destacar que a afirmação da presidente da ACERP resumia em um parágrafo os grandes desafios “de todos nós nessa sala. Meus, como educadora, que é a função que mais exerço hoje em dia, e de vocês como comunicadores diretos da produção da Rádio MEC" ${ }^{\text {186 }}$. Um profissional consciente para atuar no campo da "responsabilidade social do jornalista" (MEDINA, 1982). ${ }^{187}$

Alfredo Bosi (1992), que inspirou a epígrafe deste capítulo, nos apresenta em um parágrafo uma breve, mas complexa, noção de cultura a partir da Antropologia. Segundo ele, esse seria o significado mais geral que se conservava até aqueles dias de 1992, quando da publicação do livro Dialética da Colonização. A primeira frase, em sua complexidade, é uma provocação a qualquer projeto de televisão pública e, mais ainda, para a compreensão e entendimento de dirigentes, programadores, enfim, produtores de sentido dessas prestadoras de um serviço público de comunicação. A frase complementar de Bosi, situa o papel da educação no contexto, "como o momento institucional do processo". E aí justificava-se o binômio educação e cultura - se fossem dados a eles, na prática, o sentido proposto por estudiosos como Bosi, Canclini e Medina.

Jesús Martín-Barbero, Germán Rey e Omar Rincón escreveram a pedido do Ministério de Cultura da Colômbia, em 2000, o documento Televisión pública, cultural, de calidade ${ }^{188}$, com o objetivo de pensar a Televisão Pública a partir de três campos: "o sentido de fazer, pensar e desenhar uma televisão pública cultural e de qualidade; a televisão pública dentro do

\footnotetext{
${ }^{186} \mathrm{Com}$ as diretrizes apresentadas por Cremilda Medina, percebi, na escuta atenta, que muitos profissionais tinham aprendido aos "trancos e barrancos as fórmulas mais primárias da linguagem profissional, fixam-se nelas, ingressam numa mediocridade inconsciente e se rotinizam, no mínimo sem nunca aspirar - nem por curiosidade - a dinâmica da inovação". E então, segui um caminho - o que a professora afirmava sobre a linguagem, ajustava-se ao projeto de mexer com a cabeça dos produtores de sentido: “...na medida em que as ferramentas construídas ao longo do tempo são dominadas, torna-se mais viável a renovação, o aprimoramento qualitativo e a multiplicação de mensagens mais afinadas" (MEDINA, 1982, p. 111). O clímax do processo foram os encontros com a professora, narrados neste capítulo.
}

${ }^{187}$ Essas reflexões eram resultado da minha passagem pelo Mestrado na ECA/USP, quando transitei entre a academia e a televisão pública, procurando aproximar a universidade dessas instituições, o que ainda não era frequente na época e, neste 2017, constatamos com satisfação iniciativas assim como o crescimento do número de profissionais buscando a especialização em instituições acadêmicas. Cito como exemplo, pesquisas desenvolvidas pela Universidade de Brasília ${ }^{187}$ e a Universidade Federal do Rio Grande do Sul, nesta, com estudos desenvolvidos na Faculdade de Biblioteconomia e Comunicação ${ }^{187}$, ambas em parceria com a EBC, entre outras universidades brasileiras e emissoras públicas.

${ }^{188}$ Este documento buscou pensar a Televisão Pública a partir de três campos: "El sentido de hacer, pensar y disenãr una televisón pública, cultural y de calidad; La televisión pública dentro del nuevo escenario de la televisión y la televisón como escenario de encuentro de un país; La Televisión Pública como propuesta integradora de lo cultural y lo educativo". (REVISTA Gaceta, no 47, Ministeriomde Cultura, 2000, p.50-61). 
novo cenário da televisão e a televisão como cenário de encontro de um país; a televisão pública como proposta integradora do cultural e do educativo". Centravam nessas duas palavras, cultura e educação, a nova televisão pública que se idealizava naquele momento pelo Ministério da Cultura colombiano. Este foi um estudo amplo, conforme citado no capítulo 1, que traçou as linhas mestras que seriam seguidas mais tarde quando da transformação do Inravisión, que geria a Señal Colômbia, no RTVC - Sistema de Medios Públicos. Para os três professores e estudiosos da comunicação,

sólo es verdadeiramente cultural aquella televisión que nos se limita a la transmisión de la cultura-ya-hecha sino que trabaja en la creación cultural a partir de sus próprios "modos de ver" la vida social, de sus recursos, linguajes y potencialidades expressivas. Aquella televisión que realiza la conexión entre la acelerada y fragmentada vida urbana con el frujo de las imágenes, entendendo por éste tanto la polivalência mediante la que junta información y experimentación estética, conocimiento y juego, cultura y disfrute, como la composición y ensamblaje de los géneros y discursos más extraños entre sí.

Dois anos depois, Barbero (2002, p.71-72) voltou a tratar dessa televisão que não se restringe "à transmissão da cultura produzida por outros meios, mas trabalha na criação cultural a partir de suas próprias potencialidades expressivas", endossando a reflexão de Cremilda Medina com os "produtores culturais" da Rádio MEC. Para Barbero, essa noção ultrapassa a percepção singela e restritiva de ter alguma faixa da programação com conteúdo cultural, "mas sim ter a cultura como um projeto que atravessa qualquer um dos conteúdos e dos gêneros".

As provocações de Medina vinham das últimas décadas do século 20, como registra em várias publicações, mas trago aqui a referência do livro Novo Pacto da Ciência - A crise de paradigmas - $1^{\circ}$ Seminário Transdisciplinar, por ela organizado em 1990. Nas páginas 193 a 205, a autora reconstitui a visão do Jornalismo e a Epistemologia da Complexidade com um referencial na epígrafe de Néstor Garcia Canclini (1983), que também me acompanhou nesta pesquisa e nas experiências profissionais que envolveram produtores de sentido de instituições de comunicação pública entre 2003 e 2011. O antropólogo argentino adota o uso do termo cultura para produção de fenômenos que contribuem, por meio de representação ou reelaboração simbólica das estruturas materiais, para a compreensão, reprodução ou transformação do sistema social. (Grifo nosso) Em síntese, era o que deveria ser entendido pelo agente (ou produtor cultural), de uma maneira geral, qual seja perceber que "a cultura diz 
respeito a todas as práticas e instituições dedicadas à administração, renovação e reestruturação do sentido" (CANCLINI, 1983, in MEDINA, 1990).

Lohisse (1969) desqualifica a visão preconceituosa que se percebia entre alguns produtores em relação à noção de cultura. Isso se observava na referência a programas de música popular, na MEC AM, e de música de concerto da MEC FM (alta cultura), embora não manifestassem, percebia-se certo preconceito. Assim, a crítica que Jean Lohisse faz a autores como Friedmann e Adorno em relação ao conceito de "vulgaridade" e "cultura autêntica", se ajusta à situação que testemunhei em alguns momentos em emissoras públicas. Segundo Lohisse, "os críticos não são capazes de ver que os conteúdos aparentemente insignificantes, são capazes de assegurar a difusão de informações, de suscitar curiosidades, alargar horizontes" (Cf fichamento Cremilda Medina, de La Communication Anonyme, 1969).

Jesús Martin-Barbero escreveu em 1997, na primeira edição de Dos meios às mediações, que a comunicação tinha se tornado uma questão de mediações, mais que de meios, "questão de cultura e, portanto, não só de conhecimentos, mas de re-conhecimento". (BARBERO, 2003, p.28). Um reconhecimento que segundo ele foi uma mudança metodológica para ver o "processo inteiro da comunicação" a partir da perspectiva da recepção, ou seja "do outro lado". Passado essa etapa, "o reconhecimento se transformou na reapropriacão histórica do tempo da modernidade latino-americana, "encontrando uma brecha no embuste lógico com que a homogeneização capitalista parece esgotar a realidade” (Ibid).

Segundo o professor espanhol, residente na Colômbia desde 1963, na América Latina a diferença cultural não significa, como talvez na Europa e nos Estados Unidos, "a dissidência contracultural ou o museu, mas a vigência, a densidade e a pluralidade das culturas populares, o espaço de um conflito profundo e uma dinâmica cultural incontornável”. Em seus estudos Barbero revelou que o popular não fala unicamente a partir das culturas indígenas ou camponesas, mas também a partir da trama espessa das mestiçagens e das deformações do urbano, do massivo. (Cf. Barbero, 2003)

E eram também essas questões que nas reuniões internas posteriores que foram realizadas na Fundação Cultural Piratini Rádio e Televisão precisávamos debater para entender o conceito de TV Cultural, para que a noção de cultura atravessasse a estrutura televisiva - privada, estatal, pública. Talvez aí esteja, na produção de conteúdos televisivos e radiofônicos, o campo não passível de fronteiras estritas. Como afirmou Medina, o 
agente/produtor cultural, esteja ele numa empresa privada ou num órgão público, se debate entre administrar conteúdos oficiais ou estabelecidos pelos poderes instituídos, os "lídertipos" ou renovar e reestruturar os conteúdos com a dinâmica dos "osmotipos (osmose cultural), e a subjetividade dos "arquétipos" (LOHISSE, 1969). A receita aos produtores de sentido era abandonar a versão técnica de ouvir um contra e um a favor, uma marca do reducionismo vigente.

Ficou na experiência dos produtores das Rádios MEC e TVE-RS - que era fundamental, como ensinou Medina, que se dedicassem à "Teoria Cultural" e procurassem enfrentar "com seriedade de pesquisa, a questão da problemática da identidade cultural", independente da área em que atuavam (economia, política, música, artes e espetáculos, etc.). De qualquer delas, não deveriam ficar "à margem da Teoria Cultural nem da Identidade Cultural" (MEDINA, 1990, p. 194). Percebi que aqueles profissionais estavam "afetos ${ }^{189,}$ para serem autores das narrativas da contemporaneidade.

Considerando o alerta da professora Cremilda, em um segundo momento, introduziríamos as discussões para que entendessem o método da leitura cultural, conforme Renato Seixas (2017): buscar e compreender nas andanças da reportagem, "os elementos componentes do repertório cultural do indivíduo e/ou grupo relacionado com o fenômeno estudado". No caso da notícia de rádio ou televisão, entender e respeitar o repertório cultural do sujeito ou fonte de determinada pauta. Mas era preciso para isso também o Gesto da Arte, como nomeia Cremilda Medina (2003): “o gesto da arte em muito se afina com o gesto coletivo e assim como a literatura, a oratura traduz o humano ser”. Esse seria um aparato para os produtores de sentido de emissoras públicas - que também se afirmam como educativas e culturais - entenderem que o "laboratório de imersão na arte dá à linguagem dialógica uma motivação complementar ao trânsito social da reportagem" (MEDINA, 2011, grifo nosso). O artista exercita sua sensibilidade percebendo a "respiração social", se insere em meio ao povo e exercita sua narrativa com "marca identitária". Esse o caminho ideal aos "aprendizes da dialogia" desenvolverem seu lado criativo para a "narrativa autoral" (sonora, imagética ou impressa). Ou seja,

\footnotetext{
${ }^{189}$ A atenção e concentração na fala da Professora Cremilda Medina, demonstrava que todos estavam "afetos" a ela e à possibilidade de processar uma nova maneira de reportar a contemporaneidade. Os gestos estavam construídos. Era preciso praticar a dialogia social (MEDINA), com a perspectiva que aprendiam naquele momento - tratar o outro (a fonte) como sujeito.
} 
"tecer os sentidos contemporâneos num amplo contexto democrárico, reconstituir as histórias de vida num cenário das diferenças culturais que se assinam nas múltiplas oraturas e cruzar as carências sociais com o gesto generoso dos pesquisadores e dos artesãos de um outro futuro despertam uma sensibilidade altamente complexa e de fina sintonia com o presente" (MEDINA, 2003, p.53).

Esse era um ingrediente, antes era preciso vencer a visão reducionista. Com Canclini (1983, p.11) extraímos outros exemplos do reducionismo que nos impregna como comunicadores - a perspectiva colonialista e viciada que nos impõe o mercado, miramos os “produtos do povo, mas não as pessoas que os produzem", como se apenas interessasse o lucro que geram, e não nos damos conta de que "o artesanato, as festas e crenças ‘tradicionais' são resíduos de formas de produção pré-capitalistas”. É fundamental que as narrativas produzidas por emissoras públicas tenham em suas diretrizes e códigos essas premissas, considerando-se que se apresentam como formadoras de cidadania, mas predominam ainda as ideias de que Os jornalistas se valem do termo cultura, não nesta acepção - produção de
sentidos ou produção simbólica -, mas identificam o termo como a produção
artística, a produção científica, ambas enquadradas como intelectuais e
geralmente provenientes dos segmentos sociais de prestígio. No máximo,
tipificam as manifestações artísticas em cultura de elite, cultura de massa e
cultura popular. Falta, no entanto, na mentalidade dos jornalistas, noções
mais abrangentes do processo de produção de significados. (MEDINA,
1990, 193)

Cremilda chama a atenção para a visão reducionista de profissionais que resistem com "seus poros de produtores culturais entupidos". Essa resistência de certa forma transpareceu naqueles dois encontros - em 27 de junho de 2003, na TVE-RS e FM Cultura, e em 27 de agosto de 2007, na Rádio MEC. Cremilda lembrou aos funcionários da MEC, "naquele ato presencial" (MEDINA, 2016), que "cultura é exatamente esta possibilidade humana de criar sentidos para as coisas". Nesse momento de colóquio, a jornalista e professora revolucionou pensares e desconstruiu os conceitos que muitos ali carregavam consigo - "cultura não é, como a confusão que se faz por aí, páginas de arte nos jornais, jornalismo cultural”. Completou com a "complexidade $190 "$ " (MORIN, s/d) da noção de cultura propostas por autores

\footnotetext{
${ }^{190}$ Recorro aqui à noção de complexidade de Edgard Morin, no sentido de que o problema da complexidade tornou-se uma exigência social e política vital do século: "damo-nos conta de que o pensamento mutilante, isto
} 
como Canclini (1983), Martín-Barbero, Rincón, Rey (2002), e Medina (1990), expressando claramente

\begin{abstract}
Porque a economia é cultura, o esporte é cultura. Qualquer área que é dividida por motivos industriais e não por motivos de conteúdo, qualquer parte é cultura. Cultura é produzir significados para o mundo objetivo, material, as coisas concretas. É, então, uma atividade mental. Se o jornalista não tem uma observação, uma sintonia fina com a realidade, ele é incapaz de criar conteúdos para uma pauta. É incapaz de criar conteúdos para um debate, por exemplo, num estúdio. É incapaz de articular sentidos na internet. (...) Os estudos contemporâneos mostram que é preciso um sujeito que junta alhos com bugalhos, que faça articulações... (MEDINA, 2007, (palestra), 2016.)
\end{abstract}

O foco naquele encontro foi a Dialogia Social e a desconstrução das consciências ali vigentes para o difusionismo. A professora questionou o paradigma da difusão do conhecimento científico e da informação da atualidade e propôs a reflexão e laboratórios de mediação autoral, em que os sujeitos - repórter e protagonista da cenal social - interagem e se transformam no que nomeou Signo da Relação (MEDINA, 2016, p.13-14). O que marcou aquele grupo, conforme foi possível perceber nos meses seguintes, foi reconhecer a necessidade de estar afeto à arte, aguçar a sintonia fina e desenvolver a capacidade de articulação, para, conforme Medina e Kunsch ${ }^{191}$, entender que domínio sagrado de uma cultura é mergulhar na arte de um povo, no gesto solidário do artista. ${ }^{192}$

Rememoro esses eventos com profissionais de duas emissoras públicas, primeiro, porque aprendi na prática do trabalho a entender as dificuldades e as necessidades de se pensar, fora da rotina das atividades, o papel de cada um. E também, que as histórias de vida ali reunidas traçavam caminhos distintos. Para encontrar um denominador comum no exercício da comunicação pública em uma emissora nessas condições, era relevante provocar a reflexão. As duas experiências aqui citadas, praticadas em emissoras públicas, foram

é, o pensamento que se engana, não porque não tem informação suficiente mas porque não é capaz de ordenar as informações e os saberes, é um pensamento que conduz a ações mutilantes". Na perspectiva desta pesquisadora, a visão reducionista dos profissionais da tevê pública para a nocão de cultura mutila a comunicação. (MORIN, Edgard. O problema epistemológico da complexidade. Publicações Europa - América, Lisboa, s/d.)

${ }^{191}$ MEDINA, Cremilda e KUNSCH, Dimas Antônio. Andança mágica em outra História. São Paulo, 2001.

${ }^{192}$ MEDINA, CREMILDA, O abraço generoso da compreensão. In KUNSCH, Dimas (et. al). Comunicação e Estuto e Prática da Compreensão, São Paulo: UNI, 2016. 
promissoras. Lamentavelmente, as descontinuidades que perseguem essas instituições não permitiram que aqueles profissionais seguissem. A grande maioria dos que trabalhavam na Rádio MEC e na TVE Brasil, que era celetista, foi dispensada com a criação da EBC. Permaneceram por um período, enquanto eram discutidos o novo organograma e a realização de concurso para preenchimento de todos os cargos. E, no período em que permaneceram vinculados à ACERP, que prestava serviços por meio de um contrato para a EBC, esses profissionais ficaram subordinados a dois chefes - o antigo, da ACERP, e o novo, que chegava com a força de uma empresa nacional de comunicação, e com a arrogância de representar uma nova televisão pública.

Aqueles profissionais chegaram a ser vistos como desmotivados e acomodados. Quando Beth Carmona e Rosa Crescente, diretora presidente da ACERP, e diretora Geral da TVE Brasil, respectivamente, ingressaram na emissora em 2003, "muitos comentavam que elas sequer conseguiriam trabalhar na emissora estatal, que aquilo era uma repartição pública”, escreveu André Mermelstein, na revista Tela Viva (dez. 2006). A reportagem "Casa Arrumada" referia-se aos comentários que se ouviam no meio: que as executivas "vindas de experiências em canais internacionais, após uma passagem premiada pela TV Cultura não aguentariam". O autor da reportagem reconheceu no balanço que preparou sobre aquela gestão, que, passados quatro anos, a realidade se mostrava bem diferente das previsões pessimistas. A revista visitou as instalações da ACERP e constatou que "alguns progressos saltavam à vista". Mermelstein se referia ao novo prédio adquirido e reformado, com instalações modernizadas; as mudanças significativas na programação, com destaque para a programação infantil de ficção, como a série Um Menino Muito Maluquinho, que dias antes recebera o prêmio Japão como melhor série para crianças. Essas descrições indicavam que as TVs chamadas educativas e culturais tinham condições, apesar das dificuldades e falta de recursos, de criarem um protagonismo tanto para público externo, como para o público-alvo os telespectadores que acompanhavam a programação no Rio de Janeiro, Maranhão (onde a ACERP tinha canais abertos) e nas emissoras que integravam a rede pública, gerenciada pela ACERP.

Havia uma esperança de continuidade. As mudanças na programação da televisão naquela gestão caminharam sobre três eixos, como informaram Carmona e Crescente naquela reportagem da Tela Viva em 2006: "reforma de programas existentes, criação de novos títulos, vendo o que faltava na programação, e o relacionamento com a produção independente". Acrescento o investimento na produção interna, como a série Um Menino 
Muito Maluquinho, que deixou tradição de competência na casa. Quando perguntaram porque não usaram a produção independente, Rosa Crescente respondeu: "É porque temos que deixar aqui um certo know-how, tem que ser uma coisa regular, que fica na TV”. E o mesmo acontecia nas rádios MEC. A relação com os produtores independentes foi salutar no período, com a chegada de novas ideias e produções. "Há títulos, como o Programa Especial, que só podem vir dos independentes, por exemplo", afirmou Crescente (Ibid). Havia programas vindos da produção independente, mas que não se relacionavam com a TV, mas com seus patrocinadores. Isso também mudou. Vale lembrar: esses programas, considerando que estamos tratando da noção de cultura em emissoras públicas configuravam-se como “produções culturais": Expedições, Conexão Roberto D'Avila, Revista do Cinema Brasileiro, e 100\% Brasil. Alguns desses programas que permaneceram na TV Brasil por um período, trocaram de nome ou de casa. Infelizmente as descontinuidades que acompanham essas instituições bateram à porta da TVE Brasil logo depois em 2007.

Diante da observação-experiência aqui narrada, duas questões se impõem: Qual a noção de cultura que as emissoras públicas propõem na abordagem de seus programas, sejam eles jornalísticos, educativos ou de entretenimento? Qual é a noção de cultura que essas emissoras propõem aos seus profissionais?

À propósito, volto ao estudo dos professores Jesús Martín Barbero, Gérman Rey e Omar Rincón, Televisión pública, cultural, de calidad (2000), já citado, sobre o que "faz cultural a televisão" :

La televisión es cultural quando se assume a sí mesma como un lugar decisivo en la construcción de los imaginários sociales y las identidades culturales, dándose entonces como proyecto específico contribuir en el ejercicio cotidano de un cultura democrática, y en el reconocimiento de la multiculturalidad del país y del mundo.

Busquei entender a raiz dessas questões, na forma como as emissoras Señal Colombia/RTVC e TV Brasil/EBC se definiam e se apresentavam em seus manuais de jornalismo, em seus portais com informações institucionais definidas nas perguntas - Quem somos? ou Quiénes somos? - a partir das reflexões apreendidas no grupo de pesquisa Epistemologia do Diálogo Social, sob orientação de Cremilda Medina. Se assumirmos a noção complexa e abrangente de cultura enquanto produção de sentidos (reprodutores, renovadores ou efetivamente transformadores) ficam então integrados na criação autoral - 
educação, jornalismo e entretenimento. Toda a produção simbólica televisiva abrange estes campos narrativos sob a esfera cultural. Ainda que os espaços de produção acomodem em especificas divisórias como nos casos da tevê pública do Brasil e da Colômbia.

\subsection{Missões e pretensões - perspectiva institucional da educação e da cultura na Señal Colombia e TV Brasil}

Iniciamos as indagações a partir das apresentações institucionais dessas organizações consultando seus portais e outras publicações produzidas para o público externo. Um catálogo distribuído às agências de publicidade em 2012 informava: "Na TV Brasil você encontra uma programação artística, científica, cidadã e cultural". O Manual de Jornalismo da EBC, lançado em 2013, entre muitos temas e reflexões sobre o compromisso com a verdade ("valor soberano a ser preservado todo o tempo"), independência e credibilidade, dedica espaço às Orientações para situações especificas. Nessas orientações, que incluem temas como educação, saúde, ciência e tecnologia, economia, poder legislativo, a página 57 se dedica à Cultura - diversidade cultural, assim reunidos. Em cinco parágrafos abordam situações variadas. Recorto aqui a referência sobre a cobertura da produção cultural, embora há espaço também ao que é entendido como diversidade cultural:

No âmbito da cobertura da produção cultural, o jornalismo dos veículos da EBC deve cultivar conceitos amplos sobre a criação artística, de modo a também acolher a produção dos que não estão consagrados, a experimentação e as manifestações ligadas a públicos restritos, muitas sem escala de mercado. É essencial, nesse contexto, a acolhida a todas as regiões do país, especialmente das identidades pouco contempladas pela mídia convencional, como índios, quilombolas e migrantes. O jornalismo da EBC também aborda a economia da cultura - traduzida em modelos de negócios, empregos, investimentos, importação, exportação e mercado.

O Manual recomenda ainda que se cultivem "conceitos amplos sobre a criação artística, de modo a acolher também a produção dos que não estão consagrados", e mais - "o jornalismo da EBC também aborda a economia da cultura - traduzida em modelos de negócios, empregos, investimentos, importação, exportação e mercado", entre outras abordagens. Pergunto: é isso que a torna uma emissora educativa e cultural? 
Em 2012, a EBC/TV Brasil assim se apresentava em seu site ${ }^{193}$ :

\begin{abstract}
A Empresa Brasil de Comunicação é uma instituição da democracia brasileira: pública, inclusiva e cidadã. Criada em 2007 para fortalecer o sistema público de comunicação, é gestora dos canais TV Brasil, TV Brasil Internacional, Agência Brasil, Radioagência Nacional e do sistema público de Rádio - composto por oito emissoras. Estes, por sua independência editorial, distinguem-se dos canais estatais ou governamentais, com conteúdos diferenciados e complementares aos canais privados. Os veículos da EBC têm autonomia para definir produção, programação e distribuição de conteúdos. Atualmente, são veiculados conteúdos jornalísticos, educativos, culturais e de entretenimento com o objetivo de levar informações de qualidade sobre os principais acontecimentos no Brasil e no mundo para o maior número de pessoas. (Grifos nossos)
\end{abstract}

Já a RTVC/Señal Colombia se apresentava, em 2012, como uma entidade descentralizada indireta, "com o caráter de sociedade entre entidades públicas indireta, constituída mediante a Escritura Pública com n ${ }^{\circ} 3128$, de 28 de outubro de 2004”, tendo como objeto social a prestação de serviços de pré-produção, produção, pós-produção e emissão de rádio e televisão. Também informava que a Señal Colombia integra a RTVC, que tem como missão prestar serviços de rádio e televisão pública eficiente e de alta qualidade, com o objetivo de que os colombianos tenham uma programação divertida, de caráter educativa e cultural e que promova a participação democrática, a construção da cidadania e a geração de identidade nacional. Já entre os princípios éticos a gestora da Señal Colombia prometia "atuar com justiça, honradez e transparência, e servir com prontidão e sem preferências". Dois anos depois, a apresentação tinha mudado um pouco. Classificava-se como uma entidade descentralizada indireta, com o caráter de sociedade entre entidades públicas de ordem nacional, com a principal função de programar, produzir e emitir os canais públicos (já citados), com o acréscimo da Señal Memória e a web pública. Complementava com a afirmação:

RTVC Sistema de Medios Públicos está comprometido com a evolução até uma rádio, televisão e web contemporâneas, dinâmicas, atrativas e mais próximas da audiência para promover e fortalecer o desenvolvimento cultural e educativo dos habitantes do território nacional. ${ }^{194}$

\footnotetext{
$193<$ http://www.ebc.com.br/sobre-a-ebc/a-empresa>. Conteúdo criado em 6 dez. 2012, 19h06. Acesso em 3 nov. 2015.

${ }^{194}<$ http://www.rtvc.gov.co/quienes-somos/mision-vision-principios-y-valores $>$. Acesso em 20 de fev. 2016.
} 
Grifei os termos educativo e cultural porque eles se mantêm neste 2017 em Quiénes somos, como reproduzo a íntegra a seguir:

Somos una entidad descentralizada indirecta, con el carácter de sociedad entre entidades públicas del orden nacional con la principal función de programar, producir y emitir los canales públicos de Televisión Nacional: Señal Colombia, Canal Institucional y Canal Uno; al igual que las Emisoras Públicas Nacionales, Radio Nacional de Colombia y Radiónica.

Como parte del proceso de convergencia el Sistema de Medios Públicos ha avanzado para ofrecer a todos los colombianos servicios y contenidos digitales a través de sus páginas web, entre las cuales se destacan sus emisoras online Señal Clásica y Señal Rock Colombia.

Así mismo, implementó el proyecto Señal Memoria que busca preservar y poner a disposición de la ciudadanía la historia del país contada a través de la radio y la televisión.

RTVC Sistema de Medios Públicos está comprometido con la evolución hacia una radio, televisión y web contemporáneas, dinámicas, atractivas y más cercanas a la audiencia para promover y fortalecer el desarrollo cultural y educativo de los habitantes del territorio nacional.

Muitas informações se repetem, com pequenas alterações e ajustes derivados das inovações da tecnologia - e mudanças auto-afirmativas de cada gerente (cargo máximo da estrutura da RTVC) que chega - e, como já referido, foram vários nos últimos tempos segundo os ex-coordenadores da Señal Jaime Tenório, Marcela Benavides e a atual Diana Diaz Soto. Ainda no portal, encontro informações sobre Qué es Señal Colombia especificamente. A descrição foca na televisão diretamente, ao contrário das informações anteriores, mais gerais, sobre a RTVC, que inclui rádios, web e Señal Memoria. Mais uma vez, a educação e a cultura estão inseridas. Em três parágrafos se descrevem de forma mais complexa, incluindo a perspectiva das inovações tecnológicas:

Es un medio público, entretenido, comprometido con el desarrollo ciudadano, la infancia, la educación, la cultura, la memoria y el medio ambiente del país.

Es una alternativa a la oferta de contenidos masivos, donde la diversidad está presente en temas, formatos, estéticas y enfoques.

Es un medio contemporáneo atento a los cambios tecnológicos que apuesta a la experimentación e innovación de contenidos en diferentes formatos, ventanas, medios, dispositivos y soportes.

Excluem o binômio, que vai ser destacado nos sete compromissos a partir dos quais trabalham: 
Desde lo cultural - Señal Colombia debe ser un espejo de sus audiencias. El canal refleja la identidad nacional desde todos los aspectos de la diversidad, tales como la diversidad étnica, cultural, social o de género.

Desde lo educativo - Debe ser un recurso pedagógico. El canal desarrolla y presenta contenidos no formales, que facilitan y promueven el conocimiento.

Desde lo público - Debe ser una herramienta útil en la construcción de ciudadanía. El canal es un referente para el trabajo y divulgación de los valores culturales, y democráticos.

Desde lo audiovisual Debe ser una experiencia cultural en si misma. Los contenidos del canal tocan e impactan la vida de sus audiencias mediante la creatividad, la innovación, el entretenimiento, la movilización y la experimentación.

Desde lo local - global - Debe ser una ventana para conocer el mundo y sus culturas. El canal sirve de escenario donde circulan relatos locales con potencia universal y relatos universales con significancia local.

Desde lo administrativo - Debe gerenciar el recurso público con eficiencia y transparencia.

Desde lo tecnológico - Debe facilitar la circulación de sus contenidos en los medios disponibles. La oferta de servicios y contenidos del canal crece y se expande de acuerdo con las posibilidades tecnológicas.

Na conversa com Diana Diaz Soto, atual diretora da Señal Colombia ${ }^{195}$, ela relatou os momentos que definiram o caminho para uma programação voltada à educação e à cultura na Señal. Entre 1999 e 2000, dão início à formulação do que se chamou PROCEM Proyecto de Cultura y Educación en Medios. Esse projeto se constituiu, segundo María Consuelo Araújo, ex-ministra da Cultura entre 2002 e 2006 (governo Álvaro Uribe Velez), em um exercício de reflexão sobre televisão educativa e cultural que "se pretendia ter no País, na qual participaram entidades públicas, privadas e a academia. ${ }^{196}$

Já Diana Diaz recorda um fato positivo para a Señal quando da criação de RTVC - em 2004 - "a programação educativa e cultural” deixou de ser interrompida para as transmissões

\footnotetext{
${ }^{195}$ Quando nos encontramos em novembro de 2015, Dia Diaz era coordenadora do Proyecto de Comunicación, Cultura y Niñez, en la Direción de Comunicaciones del Ministério de la Cultura.

${ }^{196}$ A afirmação é parte de sua apresentação na sessão inaugural na VI Muestra y Conferencia Internacional TV de Calidad 2007, que se realizou em Bogotá, Colombia, entre 30 de agosto e 2 de setembro de 2007. Disponível em: $<$ http://www.comminit.com/la/content/se\%C3\%B1al-colombia-2000-2006>. Acesso 19 jun. 2017.
} 
do Congresso ou das manifestações do presidente da República. À Señal Colombia ficam reservados "somente os conteúdos educativos e culturais, enquanto o outro canal - Señal Institucional, "y todos los esfuerzos intitucionaes, el eco de los diretivos y presidentes de essas organizacions, se va por (Señal) Institucional. Eso fue muy importante para Señal Colombia”, afirmou Diana Diaz Soto. (Informação verbal). A atual coordenadora da Señal considera que a existência do canal Institucional ajuda para que os temas políticos que incidem nos conteúdos "ya solamente se van por lado que es Institucional - que digan lo que tienen que decir, y los contenidos educativos y de cultura se protegen".

Sobre a permanência do projeto formulado em 2004 depois de muitas discussões que envolveram diferentes públicos e formadores, e já alcança 13 anos, ela manifestou: “desde mi perspectiva, desde mi punto de vista el echo de que haya habido cierta permanencia en el proyecto comunicativo, educativo y cultural de Señal Colombia tiene que ver con el fator humano que se ha venido fortaleciendo en el mismo canal". Diana relembra ${ }^{197}$ sua participação no período inicial da emissora

Cuando yo estuve ahí, yo no tenía un cargo directivo, yo era una productora delegada contratista. Pero, com mis compañeros defendíamos mucho el Proyecto. Y comenzaron a crearse una red de protección del Proyecto, donde participaban los produtores independientes. Ellos comienzaban a ganarse los concursos, a producir contrenidos, y se dan cuenta de que hay una forma narrativa y audiovisual de contar historias para Señal Colombia distintas a la televisión comercial. Y comienza a darse el interés de mucha gente que se quiere formar para estar en Señal y no porque no le dieron trabajo en $\mathrm{RCN} /$ Caracol. Y esa gente comienza a proteger también el proyecto colectivo, es lo que percebo.

Foi no período que María Consuelo Araújo respondia pelo Ministério da Cultura, que aconteceu a mudança na televisão pública colombiana, como narrado no capítulo 3 . Na retrospectiva que norteou sua palestra em 2007, Araújo lembrou as mudanças: a televisão começou a se chamar Señal em 1995 (antes era Cadena Tres) e ali já se definiu como um canal educativo e cultural. Segundo a ex-ministra, o PROCEM esboçou as bases e princípios que mais tarde seria encabeçada pelos ministérios de Comunicações, Educação e Cultura. Basicamente, como afirmou, foram cinco princípios pensados para a programação da Señal Colombia, começando pela mobilização social; pelo reconhecimento da diversidade; respeito

\footnotetext{
${ }^{197}$ Quando a encontrei em 2015, ela trabalhava na Divisão de Comunicações do Ministério da Cultura para onde foi depois que saiu da Señal. Era então responsável por Mi Señal, a programação infantil.
} 
pelo conhecimento e a experiência; transversalidade e estabilidade e, por último, a permanência dos programas. Todo esse processo foi anterior a 2004, quando a Señal ganha nova configuração e vinculação, além da companhia da Señal Institucional, que vai assumir a cobertura dos órgãos do governo e outras instituições do estado, como já informado.

Em um rápido retrospecto, María Consuelo destacou o fato de que a televisão colombiana já nasce como emissora de interesse público (no Brasil chegam primeiro as comerciais):

El país cuenta con una tradición de televisión de interés público, que además en estos años logró diferenciar la misión de cada canal. Señal Colombia se empezó a construir y a ofrecer una propuesta educativa y cultural con una franja que priorizaba a la audiencia infantil y juvenil, atendiendo el principio de la Constitución que establece que los derechos de los niños prevalecen sobre los derechos de los adultos y dejando en cabeza del Canal Institucional los mensajes del gobierno, los mensajes institucionales, el Congreso de la República, etc.

Volto a frisar que Omar Rincón também se referiu à separação entre os canais dedicados ao público e ao governo. Nesse ponto, ele fez referências ao Brasil, que já teve essa separação antes da criação da EBC:

Es que Colombia tomó una decisión que ya Brasil la tenía antes y se la quitaron, que era: a los políticos les dejamos un canal, entonces hay un canal que se llama Señal Institucional para que ellos crean que eso les sirve de algo: una mala televisión que no ve nadie pero alaba el ego de los políticos.

O professor Rincón se referia à junção da Radiobrás com a TVE Brasil, antes da EBC, quando atuava independente, que resultou num emaranhado de processos de trabalho e confundiu a separacão entre a comunicação de governo e a comunicação pública. Para Rincón, um canal exclusivo aos políticos serve como um filtro para preservar a televisão dedicada ao público. É o caso do Señal Institucional:

En eso que hagan lo que quieran los senadores, los políticos, y la otra Señal se deja para la cultura y la educación. Entonces, resulta que a los políticos, mientras no haya información, mientras no haya noticieros, journals, no les interesa la televisión publica. La dejan libre. Dejan hacer porque piensan que eso no lo ve nadie ni les da imagen pública; como no les interesa, pues no les 
importa. Los políticos son muy cortos de mente, piensan que todo sirve solamente para evangelizar, propagandizar e informar.

$\mathrm{Na}$ opinião do professor colombiano, a separação dos canais impede o uso político e permite a liberdade de produção e a qualidade da programação:

Y cuando los intereses políticos desaparecen se pueden hacer cosas muy de calidad televisiva que fue lo que pasó con Pakapaka y con el canal Encuentro (Argentina), allí no hay informativo, ni jornalismo. Lo mismo con Señal Colombia que ha tenido la fortuna de ser un canal que, como no hace periodismo, no hace jornalismo, nadie se mete con él, entonces pueden hacer una gestión un poco más autónoma, que es donde estaba Marcela Benavides, Diana Díaz, ahora está Tenorio. Entonces ellos han logrado hacer una gestión mucho más independiente y dedicada, con muy poco presupuesto logran hacer televisión de calidad, poca pero de calidad. Entonces ellos han logrado tener un poco más de autonomía. Pero obviamente una autonomía relativa porque mientras se dediquen a hacer diversidad cultural, hablen de temas que no molesten el poder, hablen de indígenas, de niños, de negros no vamos a decir nada de la corrupción, de la inequidad social colombiana, no vamos a decir nada de las violencias que nos habitan, no decimos nada de lo malo... porque eso no se puede tocar... Entonces ellos se dedican a tratar temas que son importantes para la identidad pero que no son, a la final para el televidente cotidiano, al punto de tener poca importancia para los ciudadanos. (Grifo nosso)

Embora a baixa audiência, referida indiretamente por Rincón, a Señal Colômbia é hoje reconhecida na América Latina e Europa pela sua programação. O sucesso da Señal Colombia ao conquistar premiações internacionais, garante a continuidade do "projeto coletivo", mas lamentavelmente não corresponde à sua audiência, ainda baixa por falta de divulgação, conforme apontaram alguns ouvidos em Bogotá. A repercussão dessas premiações vem alcançando a imprensa local, que acompanha o desempenho da emissora em festivais nacionais e internacionais. Trago, como exemplo, o jornal Semana (28/03/2015 $5^{198}$ ), que dedicou longa matéria com o título: La fórmula de Señal Colombia, seguido do olho - El canal pasa por un momento inmejorable: gana premios nacionales e internacionales con recursos muy inferiores a los canales privados. A reportagem referia-se ao Premios India

\footnotetext{
${ }^{198}$ Disponível em: <http://www.semana.com/cultura/articulo/la-formula-de-senal-colombia/422398-3>. Acesso em jan. 2017.
} 
Catalina de Televisión ${ }^{199}$. A Señal Colombia chegou a disputar as 12 categorias para as quais foi indicada e ao final conquistou 11 estatuetas. O triunfo, de acordo com a reportagem, teve um sabor especial: venceu os canais privados em quase todas as categorias. A única estatueta que escapou dessa avalanche de prêmios foi a de melhor música original. Os prêmios foram outorgados por um júri formado por 600 membros da indústria de televisão nacional. O jornal destacou ainda que esses não foram os únicos. A Señal Colombia conquistou prêmios também na França, Japão, Bulgaria, Brasil, Canadá e Cuba.

Los India Catalina premiou a Señal Colombia mais uma vez em 2017, além de outras televisões públicas regionais. Conforme a coluna de Omar Rincón, no jornal El Tiempo $(05 / 03 / 2017)^{200},[1]$, “Las 62 nominaciones para la televisión pública colombiana demuestran que, por lo menos para los premios, la calidad de los contenidos es reconocida." Segundo o colunista, tratam-se de "propuestas híbridas de no ficción que se mueven entre el reportaje y el ensayo". E felicitou a Señal Colombia que alcançou 27 indicações, citando também os canais regionais como "Telecaribe con 16, Telepacífico con 6, Canal Trece con 4, Telemedellín con 3, Teleantioquia con 4, Canal Institucional con 1 y Canal Capital con 1". Este prêmio, tradicional na Colombia, celebra a qualidade do audiovisual, em mais de 40 categorias. Para Rincón, o vácuo deixado pela televisão comercial levou os canais de televisão públicos a se tornarem uma alternativa a outros formatos, outras agendas, outros estilos e a incluir mais formas de ser a Colômbia. Acima de tudo, na busca da participação dos cidadãos e de suas identidades. "Y en hacer programación para niños, jóvenes y lo regional. La televisión pública es, así, nuestro único laboratorio para generar otras experiencias televisiva". Para o professor, o paradoxo é que as 62 indicações para a televisão pública e que supõem qualidade, não tem público; são programas, segundo ele, “talvez bem feitos, mas sem audiência, o que indica o grande desafio desta televisão para conquistar telespectadores (RINCÓN, 2017, EL TIEMPO).

\footnotetext{
${ }^{199}$ Os Premios India Catalina são celebrados anualmente, desde 1984, e reúne representantes mais importantes da televisão colombiana. A cermimônia acontece no Festival Internacional de Cine de Cartagena na cidade de Cartagena de Indias. Os ganhadores recebem uma estatueta da India Catalina. Disponível em: $<$ https://es.wikipedia.org/wiki/Premios India Catalina $>$. Acesso em 12 de jan. 2017.

200 Disponível em: http://www.eltiempo.com/cultura/cine-y-tv/omar-rincon-los-india-catalina-calidad-sin-ratingel-otro-lado-64466 Acesso EM 16/03/2017
} 
A Señal voltaria a conquistar premiações, dessa vez, no Brasil, no Festival comKids Prix Jeunesse Iberoamericano 2017, que se realizou em São Paulo, entre os dias 14 e 20 de agosto. Nesta edição, a Señal Colombia alcançou seis premiações classificadas entre os $1^{\circ}$ e $3^{\circ}$ lugares, conquistados em diferentes categorias como produções para 0 a 6 anos; 7 a 11 anos; e 12 a 15 anos (incluindo conteúdos de ficção e não ficção) além de mais um terceiro lugar do Júri Internacional. É importante destacar que neste ano de 2017, foram inscritos no Festival 163 conteúdos audiovisuais vindos de 12 países: Argentina, Brasil, Chile, Colômbia, Cuba, Equador, Espanha, México, Peru, Portugal, Uruguai e Venezuela, produzidos nos últimos dois anos.

Jaime Tenorio ex-coordenador da Señal Colombia, com quem conversei em Bogotá (em 18/11/2015) enumerou algumas dificuldades para conquistar audiência. Mas reconheceu os avanços:

Para todos nosotros el desarrollo del canal y su crecimiento ha sido muy
importante desde muchos puntos de vista. Porque se está haciendo
producción de calidad, porque hay producción innovadora, pero tenemos
problemas presupuestales, burocráticos y de normatividad, que también hace
el trabajo más complejo. Presupuestal porque recibimos los recursos del
Fondo de la Televisión, que administra la Autoridad Nacional de Televisión.
El Fondo se nutre de lo que pagan los cable operadores y los canales
privados y luego la ANTV reparte los recursos a los canales públicos
regionales y a Señal Colombia. Sin embargo, el presupuesto solo se
incrementa generalmente en un $3 \%$ correspondiente a la inflación. Pero ese
incremento del $3 \%$ para todas las necesidades del canal no es nada. Sobre
todo cuando se quiere que seamos un canal convergente, multiplataforma,
que trasmitamos en HD, que tengamos más eventos deportivos... Entonces,
tenemos muchas limitaciones.

Mesmo com as limitações como apontaram também Diana Diaz Soto, Marcela Benavides, Alexandra Falla e Tatiana Duplat, a Señal Colômbia percorre um caminho que vem sendo vitorioso, na conquista de prêmios, na ausência de ingerências na programação embora ainda correm o risco de um determinado gerente da RTVC decidir intervir. Certamente haverá por parte de uma grande rede de apoiadores a defesa contundente do canal.

Como já abordado nesta tese, a televisão Señal Colombia teve suas marcas assentadas no educativo e cultural. Nos depoimentos de Marcela Benavides e Diana Diaz foi possível concluir que ela segue com esse projeto, com um entendimento dos termos educativos 
culturais dentro de uma visão mais complexa. E assim definem os temas que serão tratados ao longo do ano.

Em 2 de maio de 2017, recebi de Diana Diaz Soto a resposta a algumas questões que havia formulado, para completar a pesquisa. Ela assinou a mensagem como diretora do canal Señal, vinculado à Subgerencia de Televisión - Canal Señal Colombia. Transcrevo as perguntas e as respostas:

1. Me gustaria que hable de lo que cree que es más importante acerca de Señal:

R. En Señal Colombia lo que más importa es mantener y evolucionar un proyecto de televisión pública dirigido a los ciudadanos y no a los consumidores, que no intenta vender nada, sino que busca ser reflejo de la identidade de los colombianos, además de ventanda que mira hacia el mundo.

2. En cuanto la parrilla de programación, como se hace la distribuición de los programas? Mirei en el sitio web que uested tiene una división temática muy interessante sobre tipo de programas, por gêneros, tematicas, etc.

R. Cada mes tiene una temática particular, por exemplo, en marzo fue $E l$ machismo mata, en abril Colombia se escribe, y en mayo, Todo lo que podemos ser (lanzamiento de la nueva premissa del cal). Esto se plantea desde el año anterior. En el 2016, fue Colombia, lo que somos.

3. Distribuición del tempo de la parrilla, horas/dia para el siguiente:

Resposta:

Infantil - desde la 6:00 A.M hasta las 7:00 P.M.

Cine- Películas - familiar al médio día de lunes a viernes y fines de semana por la tarde (Cine tamaño familiar) y películas para público adulto todas las noches a las 10:00 P.M. (En cine nos vemos)

Documentales - Series y unitários documentales en el resto de los horários (Prime time entre semana y fines de semana.

Otros - Especiales culturales y deportivos (Deportes distintos al futbol professional masculino - ciclismo, natación, microfútbol, entre otros, festivales de música, de literatura, de danza).

Quanto aos valores de produção de programas, em média, Diana respondeu que dependia, mas "hablamos de, en promedio, 40 millones de peso (colombiano) ${ }^{201}$ por media hora. Sobre o número de programas produzidos em co-produção ou produção independente, ela não tinha a resposta no momento e acabei não insistindo.

Em relação à ausência de jornalismo, e noticiários informou: "tenemos una norma que nos impide hacer programas de opinión y noticieros”. Esta norma, na realidade, é a cautela e a salvaguarda às possíveis intervenções como confidenciaram os entrevistados na Colômbia.

${ }^{201}$ Cerca de US\$ $13.300,00$. 
Também perguntei sobre a audiência, acreditando que estivesse aumentando em virtude da melhoria da programação e a resposta foi: "la verdad, Ibope no nos hace justicia, estamos en 0,8 de rating, pero sabemos que el universo Ibope responde a intereses comerciales y que no penetra donde está nuestro público. Sobre os projertos futuros escreveu:

Estamos estrenando nuevo slogan. Pasamos de Todo lo que somos a Todo lo que podemos ser. Eso implica nuevos desafíos. Con la franja infantil estamos representando cada vez más niños colombianos en pantalla, así como contar con los mejores contenidos infantiles de todo el mundo que no necesariamente se encuentren en los canales de cable.

Voltei a indagar, como no encontro presencial em Bogotá, se sofriam pressões ou interferência política, se tinham autonomia e independência e a resposta foi: "por lo general, no". Encerrei questionando o que pensava e como via o futuro da televisão pública: "Es un proyecto que debe expadirse a lo digital. En lo digital lo público debe conquistar nuevos terrenos". (Diana Diaz Soto, por email)

Essa última pergunta também formulei ao professor Omar Rincón, com o acréscimo de qual era o déficit da TV pública, e sua longa explanação transcrevo na íntegra, a pesar de já ter citado rapidamente em partes:

Entonces creo que el gran déficit de la televisión pública de calidad - Canal Encuentro, Pakapaka, TV Brasil, TV Cultura, todos esos canales -, el gran déficit es cómo hablarle al pueblo. Porque le estamos dejando el pueblo a Globo, a Televisa, a Caracol, a Canal 13. Tenemos muy buenos contenidos y muy buena televisión pero no está en los códigos culturales estéticos narrativos de la gente y lo popular; por eso, el televidente no se reconoce en esa calidad. Entonces de alguna forma estamos despreciando a la gente porque no estamos llegando a ellos, que es realmente lo que nos interesa. La regla de oro de la comunicación es el reconocimiento. Por eso "yo veo la televisión que me genera reconocimiento, identificación, lugar en el mundo". Como no me reconozco ahí, me reconozco más en los reality, en las novelas de TV Globo, y no me reconozco en la TV Brasil. Este es el asunto: la tv publica puede ser una televisión bien hecha, pero no hecha para el pueblo; una televisión hecha por gente que no ve televisión, sino para que otros vean. Entonces, hoy en día en América Latina las televisiones públicas que funcionan son las que no hacen jornalismo, no se meten con eso, las que se dedican a los niños porque el público infantil es exitosísimo por calidad, por audiencia y por reconocimiento. Y porque, además, hay una lucha cultural muy importante; Pakapaka está luchando los imaginarios culturales de Disney, desde Argentina, lo cual es muy interesante, y además pelea desde conceptos locales con una televisión internacional. Entonces, yo creo que es claro que el modelo de televisión como está hecho fracasó. Creo que Brasil hizo la inversa. Brasil tenía un sistema de televisoras diversas con las cuales... cada una intentaba hacer algo y cuando una estaba bien, la otra estaba mal, pero estaban como balanceadas, entonces tienes la televisión 
educativa, tienes la TV Cultura, entonces todo eso. Y cuando juntan todos, asumen el problema de las televisiones públicas de América Latina, que es una decisión política y no una decisión televisiva, ni comunicativa. $\underline{Y}$ creo que lo que está mal no es tanto que estén juntas, lo que está mal es que no hay un concepto de comunicación pública, no hay un concepto de seducción televisiva, no hay un concepto de hacer televisión de calidad, sino está más detrás de hacer un concepto de propaganda política, de educación y de información. Y lo otro es que es un lugar de empleo, de corrupción política también. Porque le da empleo a mucha gente que no tiene ni idea.

Como Diana Diaz afirmou em sua resposta por e-amil, a Señal não tem programas jornalísticos por uma norma interna. Para Rincón, isso pode ser uma vantagem. Segundo ele, a Señal Colombia teve a "fortuna" de ser um canal que, como não faz jornalismo, nada se mete com ela, como já informado anteriormente em uma citação do professor.

\subsection{A origem do educativo na televisão pública brasileira}

"O Brasil tem condições de realizar a primeira experiência em larga escala de utilização da televisão para ensinar e habilitar, com títulos formais, grandes parcelas da coletividade brasileira, adolescentes e adultos" (MILANEZ, 2007, p. 31). As palavras de Gilson Amado faziam parte de sua peregrinação para criar uma televisão voltada exclusivamente à educação, feito que conseguiu efetivamente em 1973. Neste ano, o presidente Emílio Médici assina o Decreto $n^{\circ} 72.634$ que concedia à Fundação Centro Brasileiro de TV Educativa (FCBTVE), presidida por Gilson Amado, autorização para estabelecimento de uma estação de radiodifusão "de sons e imagens" (MILANEZ, 2007, p.47). Eram os primeiros passos da TVE do Rio de Janeiro que 34 anos depois seria absorvida pela EBC, transformando-se na TV Brasil. O nome perdeu o educativo, mas a classificação de educativa e cultural se manteve institucionalmente. Vale destacar que a TVE já não veiculava mais programas didático-pedagógicos mas defendia a educação e a cultura, como noções que perpassam toda a programação de qualidade voltada à formação de cidadãos conscientes.

Em reportagem da revista Tela Viva (dez. 2006), Beth Carmona, então presidente da ACERP (Associação de Comunicação Educativa Roquete-Pinto), e Rosa Crescente, diretora Geral da Televisão, elogiaram a iniciativa do Ministério de Cultura que naquele momento articulava a criação do fórum para debater e chegar a políticas para TV pública. Segundo elas, era importante porque cada um tinha um conceito do que fosse TV pública, e a partir daquelas 
discussões se chegava a denominadores comuns. "Antes achavam que eram só as educativas, mas hoje tem TV Senado, Câmara etc", argumentou Beth Carmona. Ela lembrou que as educativas abertas tinham passado por um processo que era diferenciado, e que essa diferenciação precisava ser entendida. Em relação à extinta TVE Brasil, antes de ela se transformar na TV Brasil, Carmona afirmou naquele dezembro de 2006:

\begin{abstract}
Nós mantemos o "E" da TVE, e acho que as educativas têm que se manter assim, sem ter vergonha da denominação". E argumentou que temas como meio-ambiente, entre outros, nem sempre eram abordados na TV comercial, precisavam estar presentes na programação de uma educativa. E completou: O importante é o reconhecimento público deste tipo de comunicação para o Brasil. Hoje podemos nos orgulhar de produtos como o Observatório da Imprensa, o Roda Viva, Castelo Ra-Tim-Bum, entre tantos outros, assim como exemplos regionais em Minas, Rio Grande do Sul. (MERLMESTEIN,2006, Tela Viva)
\end{abstract}

No Brasil, a situação é distinta em relação a Colômbia. Mesmo antes da intervenção do presidente Michel Temer que instituiu uma medida provisória extinguindo o Conselho Curador, a autonomia e isenção não existiam, como atestou a representante dos profissionais no Seminário Modelo Institucional da EBC: balanço e perspectiva, promovido pelo Conselho Curador da empresa, citada nesta tese (capítulo 2), e que acompanhei nos dias 11 e 12 de agosto de 2015, em Brasília (e introduzido no capítulo anterior). Foi um momento importante para encontrar antigos colegas e ver as mudanças que tinham ocorrido depois de minha saída da Rádio MEC em dezembro de 2011. Constatei nos encontros no hall de entrada, antes da abertura do evento, que tinha ocorrido movimentações, como trocas de cargo. Os fiéis ao partido do governo não saem nas substituições de dirigentes, mas mudam de posições no grande tabuleiro de partilha de cargos. Relataram algumas trocas de cadeiras - de superintendente para assessor (salários iguais dependendo do nível), gerente executivo para assessor, - enfim, pelo tanto de cargos da estrutura da EBC, as trocas de posições foram em número considerável. ${ }^{202}$ Perguntei para alguns ex-colegas qual era a expectativa com o novo presidente, Américo Martins, que dali a alguns dias tomaria posse. Um deles afirmou: "não vai resistir muito, não é político". Pensei naquele momento que Américo iria enfrentar dificuldades ao agir como um técnico que conhece televisão, ao invés de um bajulador de

\footnotetext{
${ }^{202}$ Logo depois da saída do Américo, em fevereiro de 2016, tento consultar o quadro de funcionários que estava disponível na internet no portal da transparência, e já não aparecia no dia 10/02/2016.
} 
partido.

Como um colegiado que deve representar a sociedade, a proposta do Conselho Curador para o seminário procurou ser democrática. No ato da inscrição, os interessados eram convidados a contribuir com ideias e sugestões para o debate. Essa convocação resultou em um Caderno de Debates com a compilação das contribuições selecionadas e aprovadas pela Comissão Organizadora do evento, e enviado por email a todos os inscritos. Recebi o meu exemplar no dia 08 de agosto, tempo suficiente para ler as propostas da sociedade civil e de alguns profissionais da EBC que alimentariam as discussões nos dois dias. Integrava a comissão organizadora representantes do Conselho Curador da EBC, sociedade civil, produtores independentes, academia, Governo Federal, Diretoria e funcionários da EBC.

Pelas coincidências que ocorrem na vida de um pesquisador, o seminário aconteceu no período de troca da presidência da EBC. Nelson Breve tinha deixado o cargo e retornado às atividades como secretário de imprensa da Secom (porta-giratória). Já fora nomeado como novo presidente Américo Martins, que vinha respondendo pela diretoria-geral da empresa desde 10/02/2015, e tomaria posse logo depois, em 02 de setembro. Era, portanto, um momento oportuno para esta pesquisa, primeiro, pela chance de ouvir discussões que pretendiam fazer um balanço dos sete anos da Empresa Brasil de Comunicação, segundo, para poder conhecer as ideias e projetos do novo presidente. Já conhecia Américo Martins dos tempos da BBC, quando eu exercia a presidência da Fundação Cultural Piratini Rádio e Televisão.

Os temas foram divididos em três eixos, como narrado anteriormente - Autonomia e Vinculação, Financiamento e Sustentabilidade, Gestão de Conteúdo e Participação Social. Pelo número de trabalhos apresentados e os questionamentos, percebi que minhas angústias eram compartilhadas com organizações como Intervozes - Coletivo Brasil de Comunicação Social, Centro de Estudos da Mídia Barão de Itararé, Fórum Nacional pela Democratização da Comunicação (FNDC), Sindicato dos Jornalistas do Distrito Federal, Comissão de Empregados da $E B C$, além de profissionais que representavam os empregados da empresa. Não eram fatos novos, como apontaram autores como Eugenio Bucci, Tereza Otondo, e os estudos mais recentes de Carolina Matos, Ivonete da Silva Lopes e tantos outros que estudaram a TV Brasil/EBC em suas teses.

A solenidade de abertura do Seminário contou com as presenças de ministros como o da Secom, Edinho Silva, da Cultura, Juca Ferreira, da deputada Luiza Erundina, representando a Frente Parlamentar pela Liberdade de Expressão e Política de Comunicação, entre outros convidados. Ana Luiza Fleck Saibro, então presidente do Conselho Curador, 
destacou que o objetivo do Seminário era ampliar a discussão com a sociedade civil, com uma preocupação: que "a EBC se torne um projeto robusto independente dos projetos de governo".

$\mathrm{O}$ próximo a falar foi Américo Martins, como presidente interino da EBC, tomaria posse na presidência dias depois. Estava ali ainda como diretor geral, cargo que exercia há sete meses, e levantou como uma das questões importantes o modelo institucional da EBC. "Meu histórico é o da BBC. Não acho que devemos fazer o mesmo, não é possível. Precisamos da nossa empresa de comunicação pública".

A conselheira Rosane Bertotti começou com uma questão: o que a comunicação pública no Brasil demanda? - e em seguida respondeu - "Entendemos que a comunicação pública da EBC precisa discutir seu papel social, como se dá o debate da democratização da comunicação, ser um espaço que fortaleça a comunicação, o jornalismo e a participação social”. Rosane exerceu atividades nos movimentos sociais, como Secretária de Comunicação da CUT Nacional, Coordenadora Geral do FNDC - Fórum Nacional pela Democratização da Comunicação, além de membro da Comissão Operativa Nacional da Coordenação dos Movimentos Sociais (CMS), agricultora familiar e militante da Região Sul, participa da Federação dos Trabalhadores da Agricultura Familiar (FETRAF Brasil), diplomada em Sociologia na Universidade Federal de Santa Catarina.

A sequência da solenidade seguiu o formato de um programa de televisão: uma apresentadora da Rádio Nacional, Mara Regia, fazendo o papel de entrevistadora. Os entrevistados foram os integrantes da mesa. Destaco algumas frases, em itálico, para reflexão daquele momento, pela ordem em que falaram:

Ministro da Secretaria da Comunicação Social (SECOM) Edinho Silva:

\footnotetext{
"Meu objetivo hoje é conhecer a EBC e seus desafios. Sou defensor da EBC. Muitas vezes um governo não tem coesão. As críticas vêm e temos que recebê-las como um desafio. São muitos os desafios da EBC - não só TV Brasil e NBR. Um dos maiores patrimônios é a Rádio Nacional. Temos que ter um projeto para a retomada da Rádio Nacional. Queremos uma empresa brasileira de comunicação, que não reproduza a TV de mercado, mas que consiga chegar efetivamente à sociedade. Se queremos de fato fazer a disputa de um novo projeto, temos que chegar à população que não teve formação sofisticada. Temos que popularizar a programação, disputar audiência e produzir conteúdo que não seja elitizado".
}

Senti, pelas colocações do ministro, que Américo Martins enfrentaria tempos complicados, como se veria adiante e aqui foi narrado. O ministro da Cultura, Juca Ferreira, que participou das discussões do Fórum de TVs Públicas, em 2007, na gestão do ministro 
Gilberto Gil, afirmou que daria ali sua primeira visão dos quase oito anos da EBC. “Acompanho desde o início. Fizemos (no MINC do GIL - Ministro Gilberto Gil) seminários que produziram ideias em cima de uma televisão pública de qualidade".

Algumas afirmações do ministro demonstraram que ele defendia a vinculação da EBC ao MINC:

A TV pública tem problema sério. Em quase todos os países a TV nasceu pública. No Brasil, foi a Ditadura quem favoreceu a TV privada e sufocou as rádios públicas. A fragilidade da comunicação pública é danosa. Exemplo: Faço as compras e vejo como os pobres precisam de orientação. Andam com os carrinhos cheios de alimentos industrializados, abandonam a alimentação tradicional e adotam os produtos que a publicidade divulga. Uma boa TV pública não é cópia da BBC, que é parte de uma estrutura pública eficiente, o que não é o caso do Brasil. O Brasil ainda não investiu devidamente e precisa compreender a importância da comunicação pública. Nos seminários que fizemos, chegamos a um meio termo. Louvo a coragem da implantação, mas nós cometemos erros na estruturação da EBC. Temos um caminho enorme. Precisamos revisitar esses seminários. Ainda está distante de uma comunicação pública.

A jornalista Linda Goulart, secretária-executiva da Secretaria de Políticas para as Mulheres -SPM/PR, se apresentou como representante de $52 \%$ da população brasileira, as mulheres. À questão sobre o que a EBC poderia fazer para as mulheres respondeu: “É preciso chegar ao povo, que fica contando com uma única versão bem embalada. Estamos contaminados pela lavagem cerebral. Penso, do ponto de vista das mulheres, uma pauta externa: mulher e cultura, mulher e saúde etc".

A deputada Luiza Erundina, representando "um coletivo da Câmara" - a Frente Parlamentar pela Liberdade de Expressão e Política de Comunicação, contou que viveu o processo de criação da EBC desde o início. Deu ênfase a:

Sistema público de comunicação é um direito da cidadania. Parte da crise brasileira inclui a crise das instituições sociais. Estão caducando. Não respondem mais pelas novas tecnologias. É produtivo que uma instituição com sete anos esteja revendo o passado, e projetando o futuro à frente do campo público da comunicação. É um equivoco de antigos governos que não perceberam o caráter estratégico da comunicação. O conselho curador tem vantagem, é ativo como representante da sociedade. Encerrou com a frase: "Temos que fazer com que a crise passe.

Encerrada a entrevista, o Seminário seguiu com a apresentação das propostas encaminhadas previamente. Os documentos foram lidos pelos representantes de organizações da sociedade civil e funcionários, para um auditório de cerca de 100 pessoas entre produtores 
independentes, funcionários com cargos de confiança que atuavam nas bases Rio de Janeiro, São Paulo e Maranhão, acadêmicos, entre outros.

O primeiro texto apresentado foi o do Conselho Curador, lido pela Conselheira Rita Freire, então vice-presidente do Conselho (assumiu a presidência no dia 09/12/2015). Resumo alguns parágrafos que contribuem para a reflexão:

- O Conselho Curador depende de momentos como esse. Ele compartilha a programação e outras responsabilidades. Essas responsabilidades dependem de uma interação com a empresa e as entidades que se fazem representar. Uma das responsabilidades é ajudar a consolidar a comunicação pública brasileira.

- Hoje, temos uma empresa vinculada à estrutura de governo e outra influenciada por uma comunicação pautada pelo mercado. Ela precisa se desenvolver independente dessas duas forças. Nesse sentido, o CC aderiu aos consensos que estão no Caderno de Debates.

- Há travas que impedem esse processo de avançar. Estão nas travas a vulnerabilidade que afeta a EBC, como cortes de recursos. Um tema comum a todas as contribuições recebidas está relacionado à sua autonomia. Queremos que não seja só a vinculação e financiamento, mas aquela autonomia ampla que pode incidir na programação - poder dialogar com a sociedade. Essa autonomia depende de um empoderamento das equipes da EBC. Essa falta impacta a qualidade. Precisamos que esse seminário nos ajude a construir empoderamento e pertencimento.

Sylvio Andrade, diretor-vice-presidente de Gestão e Relacionamento da EBC, apresentou dados sobre a empresa naquele momento: sete rádios, portal, agência e três TVs (Rio, Brasília e Maranhão); sobre o quadro funcional: “somos hoje (11/08/2015) 2.373 pessoas, sendo 201 servidores do regime único". Das 2.373 pessoas, mais da metade tinha entrado nos últimos três anos (por concursos, em substituição aos funcionários da TVE Brasil (RJ) que foram demitidos, alguns com mais de 20 anos de atividades).

A jornalista Priscila Kerche, funcionária da EBC em São Paulo, já citada no capítulo 2, falou como representante dos colegas. Reproduzo o texto, na íntegra, pela relevância dos temas e problemas que apontava:

Nós, da comissão de empregados da EBC, representamos os trabalhadores desta empresa e estamos muito felizes de participar desse momento de reflexão sobre o modelo institucional 
da nossa casa. Uma reflexão de suma importância, feita quase oito anos após a criação da empresa. Tempo que pode parecer pouco, mas suficiente para expressar uma personalidade e indicar um caminho, que nós todos estamos aqui para pensar em conjunto e influenciar.

Gostaríamos de lembrar que acontecimento similar, contudo, mais consolidado, também ocorre no Reino Unido. A Royal Charter (Carta Real), documento que regula as operações da $B B C$, está em processo de renegociação - o que ocorre a cada 10 anos - e o governo abriu um processo de consulta pública.

Vemos a iniciativa do Conselho Curador, encampada por diferentes segmentos da sociedade civil e também pelos trabalhadores, como uma oportunidade de consolidarmos esta prática de consulta e diálogo permanentes. Por isso, este seminário é salutar para repensarmos esse projeto acalentado como um divisor de águas no sistema de comunicação do Brasil.

A criação da EBC em 2007, com incorporação da antiga Radiobrás, veio em resposta a uma demanda da sociedade e aponta para um marco de novo entendimento sobre comunicação pública. Esta, que se difere da comunicação privada e de governo, e que tem foco no cidadão, com a vocação de ser plural, democrática, regional e participativa. Nós estamos na expectativa de que o debate a se desenrolar aqui resulte na efetivação dessa vocação.

A Empresa Brasil de Comunicação nasce vinculada à Secretaria de Comunicação Social da Presidência da República. Acreditamos que o desenho dado a empresa correspondeu à dinâmica e possibilidades políticas da época.

Porém, apesar de a autonomia em relação ao Governo Federal para definir produção, programação e distribuição de conteúdo, estar prevista em sua lei de criação, nós temos visto nesses anos de existência da EBC, uma relação árdua entre a empresa e o governo federal, em busca dessa autonomia.

É de conhecimento público a alternância de cargos assumidos na Secom e na EBC por determinados profissionais. É muito comum que o próprio governo enxergue a $E B C$ e a $E B C$ Serviços, TV Brasil e NBR, como se fossem a mesma coisa. Também é natural a dificuldade do público em diferenciar os veículos da EBC de veículos do governo.

Portanto, acreditamos que a mudança na relação entre EBC e Estado passa pelo descolamento da EBC do poder Executivo, mas, também, pela separação clara entre produção da Empresa e prestação de serviços, que não deve privilegiar a propaganda de governo com o melhor dos nossos recursos, inclusive humanos. A prestação de serviços ao Governo Federal, por mais que complemente o financiamento da Empresa, não pode comprometer a construção de sua credibilidade junto aos brasileiros e deve ocorrer somente se for possivel estabelecer o distanciamento necessário para que a comunicação pública floresça. Afinal, a prestação de serviços serve aos objetivos da comunicação pública e não o inverso.

É fundamental o estabelecimento de um mecanismo de indicação dos dirigentes da empresa que não seja vinculado ao governo, que privilegie o histórico de atuação na área da comunicação pública e o corpo próprio da empresa, e que garanta que a sociedade seja ouvida em sua indicação. A falta de regras na nomeação de cargos de livre provimento e a nomeação pela presidência de cargos e de representantes nos espaços de participação social prejudica, e muito, o conteúdo que vai ao ar em nossos veículos.

Enquanto trabalhadores, vemos como as diretrizes previstas na estrutura de criação da EBC se refletem no dia a dia da produção de conteúdo e no projeto de carreira nossos e dos nossos colegas. 
Hoje, mais de 60\% dos empregados da EBC têm em média três anos de empresa, tempo que coincide com a data de realização do último concurso público. Ao fazer o concurso, bater ponto e vir aqui debater o modelo institucional da EBC estamos acreditando no projeto nacional de comunicação pública. Um projeto que exige condições de trabalho para ser concretizado. Para que a estrutura esteja pronta e que os profissionais possam se dedicar a produzir conteúdo para o cidadão.

Reivindicamos que os trabalhadores envolvidos nesse projeto tenham garantia de permanência e possibilidade de realização de seus projetos profissionais e de vida. Estamos nos dedicando para além do desrespeito diário ao nosso acordo coletivo e da nossa carga horária, ou mesmo da falta de perspectiva de ascensão na carreira dentro da empresa.

A criação de um novo plano de cargos e salários na EBC se arrasta há quatro anos. Nós acreditamos que este plano deve refletir autonomia em relação ao governo. Com a objetivação da nomeação de cargos, por meio de processo seletivo interno. E impedindo que um novo modelo de gratificação permita que ela seja dada de forma discricionária, aumentando a subordinação e colocando limites aos profissionais na produção de conteúdo independente.

O Conselho Curador, que deve ser uma espécie de fiador dessa autonomia, protegendo contra influências indevidas, ainda sofre com a prerrogativa da Presidência escolher, entre uma lista tríplice, os nomes a serem nomeados a partir da indicação da sociedade. Cremos que ele é um espaço fundamental na garantia da autonomia frente a governos e ao mercado. Este Conselho só cumprirá seus objetivos legais se tiver condições concretas de atuar com liberdade, com a participação da sociedade civil em sua composição de forma majoritária, como prevê a atual legislação.

Mesmo no Conselho de Administração, a vaga destinada ao representante dos trabalhadores ficou dois anos vaga após a eleição - foi esse o tempo para que o eleito fosse empossado.

Precisamos avançar na criação e consolidação de comitês de programação e editorial, garantir projetos continuados de formação dos funcionários, como um programa de pósgraduação em comunicação pública, enquanto a criação da Escola Nacional de Comunicação Pública não é viabilizada.

E tão importante quanto o esforço para assegurar a autonomia no âmbito da gestão é dotar a empresa de fontes de financiamento robustas e estáveis. A $1^{a}$ Conferência Nacional de Comunicação, que reuniu dezenas de milhares de pessoas para discutir as prioridades para a mídia no país, aprovou a criação de um fundo para as emissoras públicas, em especial para a $E B C$.

É urgente avançarmos na regulamentação sobre os sistemas público, privado e estatal, de maneira a garantir às emissoras públicas, em geral, acesso a fontes de financiamento. Em especial, defendemos a regulamentação da Contribuição para o Fomento à Radiodifusão Pública, prevista na legislação que criou a empresa, para que ela atenda ao conjunto do campo público e não apenas à EBC.

Acreditamos que a EBC representa, antes de tudo, esperança. Esperança de uma comunicação democrática, plural, regional, inovadora, destemida, participativa. E entendemos que essa comunicação constrói, necessariamente, uma sociedade melhor e mais justa. Mas também com a participação e valorização daquelas pessoas que a fazem, aqui, no seu dia a dia. Acreditamos no modelo de comunicação pública, e estamos aqui para que a $E B C$ tenha vida longa e que amadureça. Que tenha forças para sobreviver a processos de 
sucateamento e emparelhamento, que hoje atingem a TV Cultura de São Paulo. Em solidariedade aos nossos colegas, queremos a TV Cultura Viva.

Queremos o fortalecimento da EBC em sua função de produtora, e afastar um possível projeto de empacotadora de conteúdo. Para além da questão primordial da garantia de uma linha editorial sólida no jornalismo, acreditamos que é somente valorizando a produção interna - que não está presa às amarras do mercado independente ou comercial - que a $E B C$ conseguirá se tornar o grande celeiro de inovação e experimentação que ela foi criada para ser.

E lutar contra esse sucateamento e terceirização da produção não significa fechar as portas para outros atores, especialmente de movimentos sociais e comunidades. Pelo contrário, significa abrir canais para que os brasileiros possam produzir dentro da nossa casa, a partir de nossa linha editorial, que carece de ser elaborada de forma coletiva, aproveitando os talentos que temos aqui.

A população tem o direito de contar com diferentes formas de produção e participação na comunicação, incluindo a possibilidade de definição, planejamento, monitoramento $e$ avaliação de todas as instâncias que fazem parte da gestão dos meios públicos. Por isso este seminário nos anima, em uma direção muito positiva.

Grifamos alguns parágrafos que apontam que naquele momento era unânime o reconhecimento da falta de autonomia tanto externamente, pelas organizações da sociedade civil, como internamente conforme indicavam os próprios profissionais, testemunhos diretos das operacões. Esse é um caso que entristece e, embora não tenha acompanhado diretamente a TV Brasil e as emissoras de rádio nos últimos tempos, recebo indicações de ex-colegas de que essas situações não mudaram, os cargos continuam sendo loteados entre "amigos" do poder governamental, e o jornalismo permanece submetido aos interesses dos mandantes.

\subsection{A visão de um ex-dirigente (que interrompeu seu mandato)}

$\mathrm{Na}$ troca de mensagem com o ex-presidente da EBC Américo Martins pedi para que descrevesse sua posição sobre o papel e importância da televisão pública para a sociedade. Sua resposta chegou no dia $1^{\circ}$ de maio de 2017:

A TV pública tem um importante papel a desempenhar na sociedade; ela deve informar as pessoas sem paixões, sem opinião, sem ser tendenciosa. Também é dever da TV pública complementar algumas áreas do mercado, oferecendo produtos que as TVs comerciais não têm interesse ou condições de fazer. Mas não pode ser só isso. Ela deve competir e tem que brigar por audiência. Ela é mantida com dinheiro do público, portanto precisa dar algo em retorno para toda a sociedade. Quem paga tem o direito de receber uma boa comunicação de volta. 
Atualmente exercendo o cargo de Editor de Parcerias Globais da BBC, em Londres, Martins escreveu que sempre defendeu a tese de que o melhor modelo para qualquer país deve incluir "as três pernas da comunicação: comunicação privada, comunicação pública e comunicação estatal". Declarou não ser um militante da comunicação pública - "sou um jornalista e executivo, que já trabalhou com várias formas de comunicação - e nem acha que ela seja necessariamente melhor do que as outras. Considera, no entanto, que são igualmente importantes e complementares e que um país que tenha essas três pernas de comunicação estará sempre mais bem equipado para proporcionar uma boa oferta de comunicação para seus cidadãos - "e tende a ser mais democrático também". Como um jornalista que trabalhou em emissoras comerciais, afirmou:

Não demonizo a comunicação privada. Pelo contrário: acho que a comunicação privada, forte e independente, é muito importante e fundamental em qualquer democracia. E a comunicação estatal é importante para informar, imparcialmente, a população sobre atos do Estado (e não de governos).

Martins deu o exemplo da BBC em que, nada menos do que $96 \%$ da população da Grã-Bretanha, utiliza algum dos produtos da empresa toda semana (TV, programas de rádio, internet, mídias sociais, celular). Ou seja, como o pagamento é "universal”, a empresa precisa produzir produtos que também atendam praticamente a toda a sociedade. A audiência é também praticamente "universal" no país. "O mesmo princípio deve se aplicar a todas as empresas públicas de comunicação: não pode ser só nicho, tem que entregar bom valor a quem paga. Com boa programação, coisas surpreendentes, informação de qualidade, etc.”

Questionei ainda, diante dos acontecimentos que impactaram a televisão pública no Brasil e na Argentina, quais são as principais fragilidades da televisão pública que provocam descontinuidades e desconstruções e que saídas vê para esses equívocos dos governantes: "A TV pública na América Latina não tem a tradição e a força das TVs públicas eruropéias ou mesmo dos EUA. A PBS americana tem boa audiência, boa aceitação na sociedade, e é independente de governos. É um bom exemplo”. Sobre o modelo de financiamento, Américo afirmou que o ideal seria um misto de taxas como a licence fee (da Grã-Bretanha) e arrecadações diretas na sociedade, como faz a PBS americana. Quanto mais fontes de recursos, mais independência. Também é possível e desejável que existam co-produções e parcerias com empresas e órgãos que financiem parte da produção - segundo regras públicas, transparentes muito rigídas de independência editorial. "Nas verbas que vem dos cofres públicos (seja por impostos ou licence fee) o ideal é ter uma receita fixa, determinada, por 
vários anos seguintes (e que não pode ser alterada pelo governo de plantão). Isso dá mais estabilidade e independência para a empresa".

Em relação às intervenções, escreveu que "no fim da linha o mais importante de tudo é a independência editorial. E isso não quer dizer dar liberdade total ao gestor. Isso quer dizer mostrar TODOS os lados das principais discussões, promover debates, ser plural. Não ter lado e nem opinião". Também perguntei a Américo Martins que relações essas emissoras devem manter com o Estado? E como se relacionar com a sociedade e seu público? Sua resposta: "O ideal é que a empresa pública responda diretamente à sociedade, muito provavelmente com supervisão do Poder Legislativo. Mas com independência. E deve ser aberta. Tudo numa empresa pública de comunicação pode e deve ser aberto ao público, quando demandado". E a programação, como deve ser definida a grade? Américo considera que a grade, como em qualquer outra emissora aberta, deve ter boas atrações, deve ter programas de todos os gêneros, deve ser plural. Também tem que abrir espaços para áreas que costumam ser mal "cobertas" por outras emissoras, como temas que não têm atrativo comercial. Martins deu exemplos do que não é atrativo para as privadas:

\begin{abstract}
Esportes amadores e de categorias inferiores; e programas infantis (no Brasil, que já não atraem mais atenção e interesse das comerciais). Mas deve sempre buscar maximizar sua audiência. Ela tem que oferecer coisas inteligentes e interessantes para todos os segmentos da sociedade - que, afinal, é quem paga pela TV pública. A grade também tem que seguir três linhas mestras: tem que informar, educar e entreter as pessoas.
\end{abstract}

Américo Martins encerrou o diagnóstico indicando caminhos para que as emissoras públicas ganhem audiência e apoio do público: “fazer programas de qualidade e surpreender". As respostas não foram muito diferentes das considerações feitas, em vários momentos desta tese, por Omar Rincón, estudioso e crítico de televisão na Colômbia.

A referência do ex-dirigente da EBC de que a TV pública deve informar, educar e entreter segue na linha defendida por Cremilda Medina, em sua experiência bem-sucedida com alunos da Graduação da USP, que deu origem ao livro de reportagem Farra e Alforria (1992). Nesse trabalho, os "jovens repórteres do projeto São Paulo de Perfil", saíram em busca da gargalhada. "A alegria que resiste aos constantes esquartejamentos da História aí está na rua, no bar, na brincadeira do carnaval, no faz e conta do sonho ou no mergulho do inconsciente", escreveu Cremilda Medina na Apresentação. E é esse entretenimento que deve rechear a programação das emissoras públicas: permitir ao brasileiro reconhecer-se nos 
dramas e alegrias de seu cotidiano. Ou, como escreve Cremilda Medina, "Na aventura humana do cotidiano, cada pequena ou grande farra assina uma carta de alforria". (MEDINA, $1992,7)$ 


\title{
Considerações semifinais
}

\section{Retrocessos, recorrência histórica: até quando?}

\author{
... América companheira \\ Brasil meu irmão, \\ esta é a hora exata \\ de caminharmos \\ de braços dados com a história; \\ Canta \\ sobre as vertigens das horas \\ e a terra acumulará a \\ voz rubra \\ da tua mensagem.
}

E quando esta hora vier à superficie visivel do nosso horizonte, quem te impedirá de assumir o comando do trem, escolher a rota e fermentar a velocidade locomotiva da tua história, com a força da tua combustão?! (PROENÇA, 1980 ${ }^{203}$ )

Abro essas rápidas considerações com a epígrafe em que o escritor da Guiné-Bissau Hélder Proença descreve um Rio de Janeiro de todas as épocas. Datada de setembro de 1980, sua percepção sensível do cotidiano carioca tece uma cena que se ajusta a qualquer momento e situação, incluso a contemporaneidade deste século 21. Vejo em seus versos a força que desejo para continuar na defesa da comunicação pública, representada por emissoras independentes, isentas e autônomas. Pode estar longe, mas seguimos na trilha como terroristas homeopáticos (MEDINA, 2004).

Nesses tempos de recuos, retrocessos, de recorrência histórica o poema de Proença é um estímulo: "quando o momento chegar quem te impedirá de assumir o comando do trem? Uma espécie de "desperta" para que encontremos forças na nossa combustão, na nossa coragem. Chegar a essa etapa da pesquisa com a sensação de que é preciso continuar, que não existe o ponto final, significa seguir como terrorista homeopática ${ }^{204}$ na busca por um sonho inalcançável no Brasil de hoje.

\footnotetext{
${ }^{203}$ Poema de Hélder Proneça, da Guiné-Bissau, citado in: MEDINA, Cremilda. Sonha Mamana África, São Paulo, Edições Epopéia, 1987.

${ }^{204}$ MEDINA, Cremilda. As expressões marcadas em itálicos foram proferidas por Cremilda Medina, em sua palestra aos profissionas da TVE RS, em 27/06/2003, em Porto Alegre. Repito aqui por perceber como elas impactaram nos profissionais da TVERS e Rádio FM Cultura. Terroristas homeopáticos, como ela lembrou, foi ouvida do escritor e médico Pedro Nava, em um encontro que tiveram pouco antes de sua morte. Nava se referia à sua "grande utopia na década de 30 que era trabalhar na prevenção e não na cura exclusivamente". As circunstâncias na época impediam que ele pudesse sonhar com a medicina preventiva na área da saúde. Expostos alguns avanços reconheceu que continuávamos caminhando. Foi então que manifestou: "temos que apostar no terrorismo homeopático". Segundo Cremilda, ele chegou a mais de 80 anos como "terrorista homeopático".
} 
Percorri nesses últimos anos, incluindo a fase anterior à entrada no Doutorado, um caminho que me permitisse entender os fatos vividos e/ou presenciados, com a ajuda da bibliografia, das trocas no grupo de pesquisa Epistemologia do Diálogo Social, nos encontros com profissionais colombianos, no convívio com profissionais brasileiros e na partilha com especialistas, estudiosos e militantes da comunicação pública. Em todo o percurso tive a consciência do meu papel como jornalista e pesquisadora, longe da tarefa de um historiador, pela falta de competência especializada. Usei a memória - minha e dos interlocutores ouvidos -, com o discernimento de que mesmo ela tem suas restrições, embora também sua validade, como aprendi com Elizabeth Cancelli durante sua disciplina Política, História, Cultura e Poder que percorreu uma fase da história do Brasil que coincide com a criação das televisões educativas, e da qual fui aluna atenta. E é a ela que recorro agora:

Nosso argumento de partida para a reflexão sobre memória e
História está ancorado na aversão à sinonímia entre memória e
verdade e/ou na sua consequente versão de que conhecer o
passado seria passo fundamental para que a História fosse
descoberta e sanada e, portanto, para que ela não se repetisse.
Ou seja, creio que como fomos contaminados na História pela
aceitação de uma fluidez entre memória e História que fez
prisioneira a rememoração. Uma espécie de rememoração
contaminada por um passado que passou a ser lembrado não
para o reconhecimento, ou destamponamento, como chamamos
atenção em nossa apresentação, mas para esconder, obliterar.
Um passado mostrado a partir de representações repletas de
ambivalências discursivas. (CANCELLI, 2017, p. 122. No
prelo)

Diante desse raciocínio, volto ao presente com a consciência de que as emissoras estudadas continuam sob risco, e a causa é a mesma: a vinculação aos governos. As consequências: a falta de autonomia, independência, isenção.

Trago esse testemunho, fruto de reflexões que nasceram de dúvidas, indagações e angústias. É o resultado de anos de observações colhidas no exercício profissional em diferentes emissoras "públicas" e de pesquisas desenvolvidas ao longo do curso de mestrado da USP, e para elaboração dos citados livros Rádio MEC - Herança de um sonho e TVE Brasil - Cenas de uma história, e dos encontros com profissionais colombianos. E também de percepções captadas no decorrer do trabalho na Rádio MEC, no período 2007-2011, quando surge e se implanta a Empresa Brasil de Comunicação (EBC). 
E, como essa constatação não é isolada da realidade, reproduzo aqui o que me disse o professor Omar Rincón quando comentei sobre as dificuldades que enfrentava a TV Brasil/EBC naquele momento, novembro de 2015, com os funcionários em greve e muitos questionamentos sobre independência:

Le voy a hacer como una introducción. En este punto, a este momento, yo creo que la televisión pública en América Latina y en el mundo y en Brasil es un fracaso. Yo creo que la televisión pública no funcionó y no está funcionando. Y no funciona y no está funcionando por múltiples razones. Una razón es que nunca ha podido ser autónoma e independiente de los gobiernos. O sea, no ha podido ser las voces, los relatos, las imágenes de los ciudadanos sino del gobernante de turno. Entonces, tanto en Brasil, por lo que tú me cuentas, como en Argentina, como en Bolivia, como en Colombia, como en España, como en toda parte, cuando ingresa un nuevo gobierno, cambian los directivos. Y al cambiar los directivos, se cambia la orientación de producción de contenidos, de formatos y de estilo de cada televisora o cada radio, o cada medio público. Entonces, creo que esa autonomía que nos venden como modelo $\mathrm{BBC}$ nunca ha existido ni siquiera en la $\mathrm{BBC}$ de Londres. $\mathrm{O}$ sea, que eso no es tan cierto que exista un proyecto claramente público como se quiere pretender. Entonces me parece que ese es el primer factor. No hay televisión pública ni medios públicos porque hay demasiada injerencia de los gobiernos en la gestión, programación de contenidos y diseño de los canales.

Lo segundo que pasa es que normalmente la televisión pública ha sido equiparada a que es... igual a televisión cultural y educativa, y creo que eso es un error, porque una cosa es la televisión educativa, otra cosa la televisión cultural y otra la televisión pública, porque lo público no es educar y culturizar, sino el escenario de la ciudadanía y la diversidad cultural y la pluralidad de opiniones, es la televisión de la gente... y si es televisión debe ser entretenimiento.... O sea, se debe hacer televisión de calidad, y eso no significa cultural y educativa, y que sea solo documental. ¿Por qué siempre tenemos que educar a la gente o tenemos que culturizarla? Educar y culturizar al pueblo es un acto de soberbia de los ilustrados y que creen que son cultos y educados. Se olvida que lo que hay que hacer es televisión, en el ritual televisivo, o sea ese espacio de relajación cotidiana que todos habitamos cuando prendemos la pantalla. Y por hacer educación y cultura, lo último que se hace es televisión. Primero hacen cultura, o primero hacen educación, pero lo último que hacen es televisión. Y al no hacer televisión se olvidan de que la gente, lo que "entra" es a ver televisión (relajación, reconocimiento, entretenimiento), no a educarse y no a culturizarse.

El tercer punto, de por qué ha fracasado, tiene que ver con que... como depende de los gobiernos no tiene políticas de gestión televisiva, sino de gestión política o de institución gubernamental. O sea, no se gestiona como un canal de televisión. Un canal de televisión se gestiona técnicamente, a largo plazo, o sea, no puede cambiar cada dos años, cada año de directivos; sino que se programa en tecnología, en programación, en contenidos, en proyectos, en modos de contratar por propuestas de calidad. Cuando se vuelve gubernamental, entonces para hacer un contrato te demoras un año, el programa que pensabas que te ibas a demorar haciéndolo 6 meses te demora tres años, la burocracia te mata. $\mathrm{Y}$ es lo mismo contratar un programa de televisión que un puente, o que una casa o que un edificio, o que una carretera o una rúa. Entonces, ese modelo de gestión atenta contra a 
televisión. A mí me gusta una idea tuya, te contrato y hacemos el programa de televisión, y con cada proyecto se evalúa su continuidad o no.

Y el cuarto punto por lo que ha fracasado es que está dedicada básicamente a un proyecto político sobre todo de carácter periodístico, "jornalístico". Y entonces resulta que a la televisión pública, el "jornalismo" le ha hecho mucho daño, porque los periodistas y políticos solo entienden una sola forma de hacer televisión, que es los informativos, los documentales y no entienden que la televisión es diversidad de formatos. Entonces, creo que siempre que los "jornalistas" manejan la televisión pública la vuelven una cosa de noticias y resulta que la gente está aburrida de noticias. No quiere ver noticias más en su vida. Y menos de propaganda del gobierno. Entonces es como crear una cosa de círculo propio para ellos.

En medio de todo eso, hay que asumir y quitar una mentira, o sea, ya no mentir más y decir: "como no puede ser independiente, no puede ser autónoma, no se puede hacer televisión, no se puede hacer buena televisión si no que lo que toca hacer es propaganda política, pagar favores políticos, dar empleo político". Pues lo mejor sería asumir que es una televisión gubernamental y olvidar la televisión pública. Asumir que somos gubernamental - y está bien -, porque siendo gubernamental tu le puedes exigir que tenga coherencia con el programa o plan de gobierno. El problema de lo público es que... se adueñan los gobernantes.

Dessa longa análise de Omar Rincón resta avaliar as ausências a serem preenchidas no decorrer dos tempos. Américo Martins, hoje na BBC em Londres, como informado, não considera que as emissoras públicas tenham fracassado. Não é um contraponto à análise do professor Rincón, mas uma opinião distinta. Em mensagem que trocamos por email em 03 de janeiro de 2017, quando já estava na BBC em Londres, como já informado, ele escreveu: "não acho que a TV pública fracassou, de forma nenhuma”. Reconheceu que algumas estão em crise, "mas se você comparar com as empresas privadas de comunicação... Não sei se estão melhores não, muito pelo contrário". E, nesse ponto, se referiu à $\mathrm{BBC}$ :

(...) no caso específico da BBC, acabamos de anunciar novos investimentos em mais 10 línguas e estamos fazendo uma grande transformação nas nossas operações, deixando a empresa cada vez mais moderna e forte. Não vejo essa crise aqui, não. A BBC continua sendo a maior empresa de comunicação da Europa, líder no Reino Unido e com novos investimentos internacionais. Não vejo crise nisso. Agora, como todas as empresas da área (privadas, públicas, estatais, etc), está tendo que se adapatar às novas condições do Mercado - mas esse é um processo que vem de algum tempo e hoje já mostra alguns sinais muito bons.

Dos capítulos aqui apresentados, colhi diagnósticos e prognósticos que apontam em direções múltiplas, ultrapassando em muito os limites propostos no título desta tese. No contexto da gestão do projeto de uma televisão pública estão inseridos desafios que ainda não se concretizam na programação das instituições em causa: 1) a definição pragmática da 
identidade entre TV pública, governamental e privada; 2) os parâmetros que balizam as noções de cultura, educação e entretenimento; 3) as especificidades histórico-culturais das origens dos projetos e as trajetórias coerentres ou não dos percursos políticos; 4) as opções dos projetos no que se refere a área estratégica do Jornalismo - informação de atualidade e contribuição para a cidadania; 5) o significado profissional e a formação dos grupos de trabalho autônomos; 6) a política econômica e as variáveis de financiamento da TV pública e da gestão independente e socialmente responsável.

Ao chegar a essas considerações semifinais, e a partir da análise de Omar Rincón e das observações de Américo Martins, reconheço os possíveis apagamentos - incidentais ou intencionais - que ficam nessa tese e me socorro mais uma vez Elizabeth Cancelli, com outra afirmação que adapto para esse momento: "Um culto de si que oblitera a História: moeda perversa do sigilo que nos impede, no exercício da profissão de Historiador de fazer aquilo que é fundamental: perguntar, perguntar, perguntar..." (CANCELLI, 2017).

Como jornalista e pesquisadora, me insiro nesta citação porque também é nosso ofício perguntar, perguntar, perguntar e, fundamentalmente, escutar. Sigo com as perguntas e com a escuta atenta. As interrogações que propus nesta tese seguem em busca das respostas, com a atenção voltada às causalidades múltiplas, às devidas contextualizações - históricas, sociais e políticas - aos diagnósticos e prognósticos, como apreendemos do Diálogo Social (Cf. MEDINA). Termino adaptando o que escrevi na apresentação, citando Borges e a lembrança do amigo e escritor Alfono Reyes: (...) para não mexer mais no rascunho, interrompo (encerro) essa etapa convencida de que seguirei com as reflexões e incertezas, consciente da incompletude. 


\section{REFERÊNCIAS BIBLIOGRÁFICAS}

ABEPEC - Princípios Éticos da Televisão Pública Brasileira. (Arquivo pessoal).

AGÊNCIA Brasil. Ricardo Melo é o novo presidente da EBC. Disponível em: $<$ http://agenciabrasil.ebc.com.br/geral/noticia/2016-05/ricardo-melo-e-o-novo-presidente-daebc $>$. Publicado em 3 mai. 2016. Acesso em 26 jan. 2017.

AGENCIA Brasil. Consad nomeia novos diretores da EBC. Disponível em: $<$ http://agenciabrasil.ebc.com.br/geral/noticia/2016-05/consad-nomeia-novos-diretores-daebc >. Publicado em 25 mai. 2016. Acesso em 26 jan. 2017

AGÊNCIA Brasil. Toffoli cassa liminar e Ricardo Melo deixa presidência da EBC; Rimoli reassume. Brasilia, 08/09/2016. Disponível em: $<$ http://agenciabrasil.ebc.com.br/geral/noticia/2016-09/toffoli-cassa-liminar-e-ricardo-melodeixa-presidencia-da-ebc-rimoli-reassume>. Acesso em 20 set. 2016.

AGENCIA Brasil. TV Pública não é mais comigo, pergunte ao Gil, diz Costa. Reproduzida pelo site da Tribuna do Paraná em 21 mar. 2007 (Por Agência Brasil). Disponível em $<$ http://www.tribunapr.com.br/noticias/tv-publica-nao-e-mais-comigopergunte-ao-gil-diz-costa/>. Acessado em 5 out. 2016.

AGÊNCIA Estado. Hélio Costa anuncia grupo de trabalho para definir funcionamento de TV pública (Da Redação). Publicado em 4 abr. 2007. Disponível em: $<$ https://www12.senado.leg.br/noticias/materias/2007/04/04/helio-costa-anuncia-grupo-detrabalho-para-definir-funcionamento-de-tv-publica>. Acesso em 13 fev. 2015.

AGÊNCIA Estado. Lula e ministros discutirão rede pública de TV. Disponível em $<$ http://politica.estadao.com.br/noticias/geral,lula-e-ministros-discutirao-rede-publica-detv,20070313p28169>. Publicado em 13 mar. 2007. Acesso em 13 nov. 2016

ALENCASTRO, Catarina. EBC cancela contrato polêmico com jornalista Sidney Rezende. Rio de Janeiro: O Globo, 21 Mai. 2016.

ALENCASTRO, Catarina; SOUZA, André de; NASCIMENTO, Bárbara. Governo muda comando da EBC, mas adia posse. O GLOBO. Rio de Janeiro, 03 Set. 2016, p.8.

AMADO, Guilherme. EBC suspende exibição de entrevista de Dilma com Luís Nassif. Rio de Janeiro: O Globo, 6 jun. 2016. Disponível em: <http://blogs.oglobo.globo.com/laurojardim/post/ebc-suspende-exibicao-de-entrevista-de-dilma.html>. Acesso em 7 jun. 2016.

ARENAS, Paula. El futuro de la televisión pública educativa y cultural. El caso Señal Colombia. In: Homenaje a la television colombiana. Boletim Cultural y Bibliografico, Número 87. Biblioteca Luis Ángel Arango, Bogotá, 2015, pp.41-52.

ARIAS, Andrés. Restreto y Gómez Agudelo: los tele-videntes. In: Homenaje a la television colombiana. Boletim Cultural y Bibliografico, Número 87. Biblioteca Luis Ángel Arango, Bogotá, 2015, pp 5-20. 
BARBERO, Jesús Martín. Dos meios às mediações - Comunicação, cultura e hegemonia. Rio de Janeiro: Editora UFRJ, 2003.

BARBERO, Jesús Martín. Hacia el Habla Social Ampliada. Entrevista Prólogo. In: In AMADO, Adriana; RINCÓN, Omar. La comunicación en mutación. Remix de Discursos. Bogotá: Friedrich Ebert Stiftung - FES Comunicación, 2015. Doc.nº 15, p.14.

BARBERO, Jesús Martin. Televisão pública, televisão cultural: entre a renovação e a invenção. In: RINCÓN, Omar. Televisão Pública: do consumidor ao cidadão. São Paulo: Friederich Ebert Stifung/ILDES, 2002.

BARBERO, Jesús Martin; RINCÓN, Omar; REY, German. Televisión pública, cultural de calidad. Bogotá: Revista Gaceta, no 47. Bogotá: Ministerio de Cultura. Diciembre 2000, pp. 50-61 (Arquivo Marcela Benavides). Disponível em $<$ http://www.robertosuarez.es/webs/comunicacionymedios/comunicacion/television/textos/ma rtin_barbero_tvpublicacalidad.htm>. Acesso em 8 dez. 2015.

BORGES, Jorge Luiz. Dialogo con Borges en la Facultad de Psicología de la UBA (Aula magna que proferiu na Facultad de Psicología de la Universidad de Buenos Aires, em 12 de setembro de 1984). Disponível em <http://oyeborges.blogspot.com.br/2010/05/dialogo-conborges-en-la-facultad-de.html>. Acesso em 7 jun. 2017

BOSI, ALFREDO. Dialética da colonização. São Paulo: Companhia das Letras, 1992, $1^{\text {a }}$ edição, cap. 1. Disponível em: <http://www.iphi.org.br/sites/filosofia_brasil/Alfredo_Bosi_Dial\%E9tica_da_Coloniza\%E7\%E3o.pdf>. Acesso em 24 abr. 2017.

BRASIL - TV BRASIL. Disponível em: $<$ http://tvbrasil.ebc.com.br/sobreatv $>$. Acesso em 6 jun. 2017.

BRESCIANI, Eduardo. TV Brasil programa entrevista com Dilma. Rio de Janeiro: O Globo, 5 jun. 2016, p.10.

BUCCI, Eugênio (org.), LEAL FILHO, Laurindo Lalo. A TV aos 50: criticando a televisão brasileira no seu cinqüentenário. São Paulo. Editora Fundação Perseu Abramo. 2003.

BUCCI, Eugênio. É possível fazer televisão pública no Brasil?:São Paulo: Novos estudos CEBRAP $\mathrm{n}^{\circ} \quad 88, \quad$ dez.2010. Disponível em: $<$ http://www.scielo.br/scielo.php?script=sci_arttext\&pid=S0101-33002010000300001\#ntb $>$.

BUCCI, Eugênio. O Estado de Narciso. A comunicação pública a serviço da vaidade particular. São Paulo: Companhia das Letras, 2015.

BUCCI, Eugênio. Temer errou com a EBC. São Paulo: O Estado de S. Paulo, 26 mai. 2016, A2. Disponível em: <http://opiniao.estadao.com.br/noticias/geral,temer-errou-com-aebc, $10000053509>$.

BUCCI, Eugênio. TV Brasil: pública, estatal ou governamental? Folha de São Paulo. São Paulo, 2 set. 2011. 
BUCCI, Eugênio; CHIARETTI, Marco; FIORINI Ana Maria. Indicadores de Qualidade nas Emissoras Públicas - uma avaliação contemporânea. Comunicação e Informação. Série Debates CI no 10 - junho 2012. Unesco. Representação no Brasil, 2012.

CANCELLI, Elizabeth. O Brasil na Guerra Fria Cultural: pós-guerra em releitura. São Paulo: Intermeios, Coleção entre(H)istória, 2017, no Prelo.

CANCLINI, Nestor Garcia. A Sociedade sem Relato. Antropologia e Estética da Iminência. São Paulo: Editora da Universidde de S. Paulo, 2012, p.245

CANCLINI, Nestor Garcia. As culturas populares no capitalismo. São Paulo: Ed. Brasiliense, 1983.

CARMONA, Beth (org.). O Desafio da TV Pública. Rio de Janeiro: ACERP, 2003.

CARMONA, Beth. A Marca da TV Pública. In: I Fórum Nacional de TV's Públicas. Diagnóstico do Campo Público de Televisão. Brasília. Ministério da Cultura, 2006 (Caderno de Debates).

CARMONA, Beth. Documentos Diversos (arquivo pessoal). ACERP, 2007.

CARRATO, Ângela. A TV Pública e seus inimigos. Disponível em: $<$ http://www.gepicc.ufba.br/enlepicc/pdf/AngelaCarrato.pdf $>$. Acesso em 2 out. 2016.

CASTRO, Ruy. Roquette-Pinto: o homem multidão. In: MILANEZ, Liana. Rádio MEC: Herança de um sonho. Rio de Janeiro: ACERP, 2007.

CIEGLINSKI, Amanda. Medida provisória e decretos modificam estrutura e trocam comando da EBC. Agência Brasil. Disponível em: <http://agenciabrasil.ebc.com.br $>$. Acesso em 02 set. 2016.

COLETIVO Intervozes. Comunicações: moeda de troca evidencia falta de política. Disponível em: <http:/www.cartacapital.com.br/blogs/intervozes/ministerio-dascomunicacoes-moeda-de-troca-evidencia-falta-de-politica-5992.html $>$. Publicado em 4 out. 2015. Acesso em 13 dez. 2016.

COMKIDS. Institucional. Disponível em <http://comkids.com.br/sobre/>. Acesso em 22 Ago. 2017.

CPDOC FGV - DIP - Departamento de Imprensa e Propaganda. Disponível em $<$ http://cpdoc.fgv.br/producao/dossies/FatosImagens/DIP > . Acesso em 25 out. 2016.

CRUVINEL, Teresa. Futuro da EBC em risco. Folha de S. Paulo, 2 jun. 2016, A3.

CUNHA LIMA, Jorge. Televisão pública em pé de guerra. IG/ Observatório da Imprensa, Disponível em:

$<$ http://jorgedacunhalima.ig.com.br/?s=O+governo + federal $+\mathrm{e}+\mathrm{a}+\mathrm{tv}+\mathrm{p} \% \mathrm{C} 3 \% \mathrm{BAblica}>$. Publicado em 13 mar. 2007. Acesso em 15 jan. 2017. 
DOSSE, François. Renascimento do acontecimento. São Paulo: Editora Unesp, 2013, p. 265-266.

EBC - Caderno de Debates - Seminário Modelo Institucional da EBC - balanço e perspectiva. Brasília: Conselho Curador da EBC, 2015.

EBC - Seminário Modelo Institucional da EBC - Documento Final - Sistematização das Propostas e Discussões. Comissão de Sistematização (Conselho Curador). Brasília, 2015. Disponível em:

$<$ http://www.ebc.com.br/institucional/sites/_institucional/files/documentofinalseminarioebc.pdf $>$. Acesso em 2 nov. 2015.

EBC - Institucional. Disponível em: <http://www.ebc.com.br/institucional/governancacorporativa/conheca-a-ebc>. Acesso 4 dez. 2011.

ELIAS, Norbert, SCOTSON, JOHN. Os Estabelecidos e os Outsiders. Jorge Zahar Editor. Rio de Janeiro, 2000.

FESTIVAL comKids Prix Jeunesse Iberoamericano. Disponível em: $<$ http://comkids.com.br/vencedores-do-festival-comkids-prix-jeunesse-iberoamericano2017/>. Acesso em 21 ago. 2017.

FNDC - Hélio Costa fala sobre TV Pública no Senado. Disponível em $<$ http://www.fndc.org.br/clipping/helio-costa-fala-sobre-tv-publica-no-senado-148372/>. Publicado em 11 abr. 2007. Acesso em 16 out. 2016

FOLHA de S. Paulo. BBC nomeia novo diretor para tentar sair de crise. Edição 23 nov. 2012. p. A 23

FOLHA de S. Paulo. Canal chapa-branca. Editorial. São Paulo, 26 jun. 2016, A2.

FOLHA de S. Paulo. Chefe da EBC exonerado por Temer reassume. São Paulo, FSP, 3 jun. 2016, A6.

FOLHA de S. Paulo. Fundação BBC diz que emissora vai mudar. Edição 12 nov. 2012. p. A18.

FOLHA de S. Paulo. TV Brasil, 5, luta contra traço de audiência. Edição 2 dez. 2012, p. E 9.

FOUCAULT, Michel. Microfísica do Poder. Disponível em: $<$ http://petletras.paginas.ufsc.br/files/2017/03/foucault-microfisica-do-poder.pdf $>$. Acesso em 10 ago. 2017.

FRADKIN, Alexandre. Histórico da TV Pública/Educativa no Brasil. In Desafio da TV Pública. Uma reflexão sobre sustentabilidade e qualidade. Rio de Janeiro: ACERP TVE Rede Brasil, 2003, p.56.

FREIRE, Paulo. Pedagogia da Autonomia, São Paulo: Paz e Terra, 1997. 
FREIRE, Rita. A disputa pela EBC. São Paulo: Folha de S. Paulo, 16 jun. 2016, A3.

FUENZALIDA, Valerio. Reformas en la TV pública de América Latina. In: De lo estatal a lo público. Medios: ?de quién y para quê? Rosa Maria Alfaro oreno (editora) Ed. Acs Calandria Y Veeduria Ciudadana de la Çomunicación Social. Lima, 2006, pg. 19-53. Disponível em: $<$ https://www.academia.edu/3191569/Reformas_a_la_TV_P\%C3\%BAblica_en_Am\%C3\%A 9rica_Latina>.

Informações Señal Colombia. Disponível em: $<\mathrm{http}$ ://www.sistemasenalcolombia.gov.co/index.php/informacion-general/quienessomos.html>.

INNERARITY, Daniel. A Transformação da Política. Lisboa, Teorema, 2002.

INPUT - International Television Public Screening Conference. Disponível em: $<$ https://en.wikipedia.org/wiki/International_Public_Television_Screening_Conference $>$. Acesso em 16 nov. 2016.

JUNGBLUT, Cristiane. Um mês depois - Foco de resistência, EBC é alvo do governo Temer. Rio de Janeiro: O Globo, 12 jun. 2016, 5)

$\mathrm{KÜNSCH}$, Dimas A. Andança mágica em outra história: uma conversa sobre a narrativa do mito. In: KÜNSCH, Dimas A. et al. Comunicação, Diálogo e Compreensão. São Paulo: UNI Editora, 2016. Também em Plêiade, 2014. p. 63-78. Disponível em: $<$ http://casperlibero.edu.br/wp-content/uploads/2015/04/E-book-

Comunica\%C3\%A7\%C3\%A3o-Di\%C3\%A1logo-Compreens\%C3\%A3o.pdf $>$.

LA NACION. Por decreto, Hernán Lombardi quedó a cargo de Paka Paka, Encuentro y DeporTV. Disponível em <http://www.lanacion.com.ar/1962447-transfieren-a-hernanlombardi-el-control-de-paka-paka-encuentro-y-deportv>. Acesso em 16 dez. 2016.

LARROSA Bondía, Jorge. Notas sobre a experiência e o saber da e o saber da experiência. Conferência proferida no I Seminário Internacional de Educação em Campinas, IEL, Unicampl, em 15 jul. 2001. Revista Brasileira de Educação. Universidade Estadual de Campinas, Instituto de Linguistica. Campinas, 2002. ScIELO. No19 (Jan/Fev/Mar/Abr 2002). Disponível em: <http://www.scielo.br/pdf/rbedu/n19/n19a02.pdf >.

LEAL FILHO, Laurindo Lalo. A melhor TV do mundo. O modelo britânico de televisão. São Paulo: Summus Editorial, 1997.

LEAL FILHO, Laurindo Lalo. Ameaçada, comunicação pública é vital para a democracia. In. LOPES, Ruy Sardinha. A Comunicação Pública em questão: crise na EBC. São Paulo: Socicom, 2016, p.20. Disponível em <http://www.socicom.org.br/55-conteudo/1023socicom-debate-a-comunicacao-publica-em-questao-crise-na-ebc $>$. Acesso em 11 jan. 2017

LEAL FILHO, Laurindo Lalo. Atrás das câmeras: Relações entre cultura, Estado e Televisão. 2.ed. São Paulo. Summus Editorial. 1988. 
LOHISSE, Jean. La Communication anonyme. Paris, Ed. Universitaires, 1969, coll. Encyclopédie universitaire, 198 p., gd. in-8, br.

MACÊDO, Lourival. O sequestro da EBC. São Paulo: Folha de S. Paulo 27 jun. 2016, A3.

MANUAL de Jornalismo da EBC. Somente a verdade. Brasília, 2013. Disponível em $<$ http://www.ebc.com.br/institucional/sites/_institucional/files/manual_de_jornalismo_ebc.pdf >. Acesso em 25 jun. 2017

MARINI, Ana Rita. Em vôo solo, ministro planeja rede estatal de televisão. Redação FNDC. Brasília, 25 jan. 2007. Disponível em <http://fndc.org.br/noticias/em-voo-soloministro-planeja-rede-estatal-de-televisao-121484>. Acesso em 5 out. 2016

MARTINS, Américo. Mensagem por E-mail - 1 mai. 2017.

MATOS, Carolina. Mídia e política na América Latina - globalização, democracia e identidade. Rio de Janeiro: Ed. Civilização Brasileira, 2013.

MEDINA, Cremilda. A arte de tecer o presente - Narrativa e Cotidiano. São Paulo: Editora Summus, 2003, ps. 61, 79, 80.

MEDINA, Cremilda. Ato presencial. Mistério e transformação. São Paulo: Casa da Serra, 2016.

MEDINA, Cremilda (Org.) Farra e Alforria. São Paulo: CJE?ECA/USP, 1992.

MEDINA, Cremilda. O invisível à luz da experiência e da compreensão (Prefácio). In: KÜNSCH, Dimas A. et al, (Orgs). Comunicação e Estudos e Práticas de Compreensão. São Paulo: Editora UNI, 2016. Disponível em <http://casperlibero.edu.br/wpcontent/uploads/2016/12/comunicacao-e-estudo-e-praticas-de-compreensao.pdf $>$. Acesso em 15 jan. 2017. E In: Comunicação e Estudos e Práticas de Compreensão. São Paulo: UNI, 2016.

MEDINA, Cremilda. Profissão jornalista: responsabilidade social. Rio de Janeiro: Forense Universitária, 1982, ps. 111, 270.

MEDINA, Cremilda; KUNSCH, Dimas Antônio. Andança mágica em outra História. São Paulo: Ed. 2001.

MEDINA, Cremilda, e GRECO, Milton (orgs). Novo Pacto da Ciência 5. São Paulo: ECA/USP/CNPq, 1996, p 351-359.

MEDINA, Sinval. Estado nacional, Estado terminal?. São Paulo, 2017.

MEDINA, Sinval. O Gigante sob suspeita. In A Agonia do Leviatã: a crise do Estado moderno.

MELO, Debora. O que está por trás da saída do presidente da EBC? Carta Capital, 4 fev. 2016. Disponível em: <http:/www.cartacapital.com.br/sociedade/o-que-esta-por-tras-da-saida-dopresidente-da-ebc>. Acesso em 26 jan. 2017 
MERMELSTEIN, André. Casa Arrumada. Diretoras contam como se deu a reestruturação da TVE Brasil, das instalações físicas à grade de programação. Tela Viva, 2006. p.42 - 44.

MESQUITA, Lúcio. O Modelo da TV Pública da BBC. In: O Desafio da TV Pública. Rio de Janeiro: ACERP, 2003.

MILANEZ, Liana. Produção de Sentidos na TV Pública: Perfil de uma experiência. Dissertação de Mestrado, defendida em 2005, ECA/USP, sob orientação da Profa. Dra. Terezinha FátimaTagé Dias Fernandes.

MILANEZ, Liana. TVE Brasil - Cenas de uma história. ACERP, Rio de Janeiro, 2007.

MILANEZ, Liana. Rádio MEC - Herança de um sonho. Rio de Janeiro: ACERP, 2007.

MINISTERIO de Cultura. República de Colombia. Marco Legal-Políticas Culturales. (Arquivo pessoal de Marcela Benavides).

MIOLA, Edna. Radiodifusão pública e participação deliberativa. Um estudo das características e dos modos de atuação do Conselho Deliberativo da FCPRTVE. Dissertação (Mestrado) Faculdade de Comunicação, Universidade Federal da Bahia, Salvador, 2009.

MORENO, Jorge Bastos. Dilma e a televisão que dá traço. Rio de Janeiro: O Globo, 11 jun. 2016, 1 e 2 .

MORIN, Edgard. O problema epistemológico da complexidade. Publicações Europa América, Lisboa, s/d.

NOBRE, G.F. Capital Social, comunicação pública e deliberação: a gestação do capital comunicacional público. In: Comunicação e política - Capital social, reconhecimento e deliberação pública. São Paulo: Summus, 2011.

NOGUERIA, Marco Aurélio Nogueira. Crises que se cruzam. São Paulo: O Estado de S. Paulo, 27/05/2917, p.2.

O ESTADO de S. Paulo. A TV chapa-branca. São Paulo: OESP, 7 jun. 2016. A2.

OBSERVATÓRIO do direito à comunicação. Fórum de TV's Públicas lança $\mathbf{2}^{\mathbf{0}}$ caderno de debates. Disponível em: <http://www.intervozes.org.br/direitoacomunicacao/?p=18137>. Publicado em 9 abr. 2007.

OTONDO, Teresa Montero. Televisão Pública: para quem e para quê. São Paulo: Annablume, 2012.

PERON, Isadora; AGUIAR, Gustavo. Ex-presidente da EBC entra com ação no STF. São Paulo: O Estado de S. Paulo, 19 mai. 2016, A5.

PORTALES CIFUENTES, Diego. Televisão pública na América Latina: crises e oportunidades. In: RINCÓN, Omar. Televisão Pública: do consumidor ao cidadão. São Paulo: Friederich Ebert Stifung/ILDES, 2002, pp.119-153. 
PREMIOS India Catalina. In: Festival Internacional de Cine de Cartagena. Disponível em: $<$ https://es.wikipedia.org/wiki/Premios_India_Catalina $>$. Acesso em 12 jan. 2017.

PRIOLLI, Gabriel. A TV pública é importante? São Paulo: Revista Cult, 2007. Disponível em: <http://revistacult.uol.com.br/home/2010/03/a-tv-publica-e-importante/>. Acesso em 10 out. 2016.

PROENÇA, Hélder. Guiné-Bissau. In MEDINA, Cremilda. Sonha Mamana África. São Paulo: Edições Epopéia, 1987.

QUINTANA, Mario. Velório sem defunto. Porto Alegre: Mercado Aberto, 1990.

REDAÇÃO Terra. Ex-ministro Luiz Gushiken deixa o governo Lula. Disponível em: $<$ http://noticias.terra.com.br/brasil/noticias/0,,OI1245157-EI7896,00-

Exministro+Luiz+Gushiken+deixa+o+governo+Lula.html>. Publicado em 13 nov. 2006.

RESTREPO, Javier Darío. Sessenta años esperando la democracia. Boletim Cultural y Bibliografico, Número 87. Biblioteca Luis Ángel Arango, Bogotá, 2015.

REY, Gérman. O cenário móvel da televisão pública. Alguns elementos do contexto. In: Televisão Pública: do consumidor ao cidadão. São Paulo: Friederich Ebert Stifung/ILDES, 2002, pp.81-118.

RINCÓN, Omar. A televisão pública: o mais importante, do menos importante. In: RINCÓN, Omar. (Org.) Televisão pública: do consumidor ao cidadão. São Paulo: Friedrich-EbertStifung/ILDES, 2002.

RINCÓN, Omar. Identidades en flujo, diversas maneras de ser colombianos. In: Homenaje a la television colombiana. Boletim Cultural y Bibliografico, Número 87. Biblioteca Luis Ángel Arango, Bogotá, 2015, pp.53-66.

RINCÓN, Omar. Los Indias son una buena señal/ El otro lado. Bogotá. El Tiempo, 29 Mar. 2015. Disponível em <http://www.eltiempo.com/cultura/cine-y-tv/omar-rincon-en-modotelevision-el-otro-lado-29417>. Acesso em 14 Nov. 2015

RINCÓN, 2017.) Los India Catalina, calidad sin 'rating' / El otro lado. Bogotá: El Tiempo. Disponível em: $<$ http://www.eltiempo.com/cultura/cine-y-tv/omar-rincon-los-india-catalinacalidad-sin-rating-el-otro-lado-64466> . Acesso EM 16/03/2017

SADOP. Los Sindicatos docentes rechazan el decreto que transfiere los canales educativos. Disponível em: $<$ http://www.sadop.net/los_sindicatos_docentes_rechazan_el_decreto_que_transfieren_los_ca nales_educativos $21466>$. Acesso em $\overline{1} 6$ jan. $20 \overline{17}$

SAMPER, Lucy Nieto de. La verdadeira historia de como llegó la televisión a Colombia. E1 Tiempo. Bogotá, 21 ago. 2014. p.18.

SECOM passa a ser responsabilidade da Secretaria Geral da Presidência, do ministro Luiz Dulci, que também comanda a pasta da Secretaria de Direitos Humanos. Portal 
Imprensa, $22 \quad$ jul. $2005 . \quad$ Disponivel em $<$ http://portalimprensa.com.br/noticias/ultimas_noticias/4340/gushiken + deixa $+\mathrm{a}+$ chefia $+\mathrm{da}+\mathrm{s}$ ecretaria + de + comunicacao $>$.

SEMINÁRIO Modelo Institucional da EBC - balanço e perspectiva. Documento Final Sistematização de propostas e discussões. Brasília: Conselho Curador da EBC, out. 2015. Disponível em:

$<$ http://www.ebc.com.br/institucional/sites/_institucional/files/documentofinalseminarioebc.pdf $>$.

SENADO Notícias. Hélio Costa anuncia grupo de trabalho para definir funcionamento de $\quad$ TV $\quad$ pública. $\quad$ Disponível em $<$ http://www12.senado.leg.br/noticias/materias/2007/04/04/helio-costa-anuncia-grupo-detrabalho-para-definir-funcionamento-de-tv-publica>. Publicado em 04 Abr. 2007. Acesso em 16 Mar. 2015.

SEÑAL - Plano De Programação Señal. Disponível em: $<$ http://www.senalcolombia.tv/industria/plan-de-programacion>. Acesso 6 jun. 2015.

SOUZA, Ana Paula. SANCHES, Pedro Alexandre. Do Estado ou do Governo. In: Revista Carta Capital, São Paulo, ed. 14 mai. 2008.

SOUZA, Renata de Paula Trindade Rocha. Políticas Culturais e televisão: O processo de conformação da Empresa Brasil de Comunicação/TV Brasil. 2014. Tese (Doutorado em Cultura e Sociedade do Instituto de Artes e Ciências). Universidade Federal da Bahia.

TELEVISIÓN de Calidade 2005 - IV Muestra y Seminário Internacional. Bogotá: Fundación Imaginario e Citurna. (Documento recebido de Adelaida Trujillo).

TVE RS. Fundação Piratini garante preservação de acervo histórico da TVE e FM Cultura. Disponível em <http://www.tve.com.br/2017/01/fundacao-piratini-garantepreservacao-de-acervo-historico-da-tve-e-fm-cultura-2/>. Acesso em 19 mai. 2017.

VALENTE, Jonas. Comunicações: moeda de troca evidencia falta de política. Do Coletivo Intervozes. Publicado 04/10/2015, em Carta Capital. Disponível em: $<$ http://www.cartacapital.com.br/blogs/intervozes/ministerio-das-comunicacoes-moeda-detroca-evidencia-falta-de-politica-5992.html>. Acesso em 13 dez. 2016.

VALOR Econômico. Américo Martins deixa presidência da Empresa Brasileira de Comunicação. São Paulo, 28/03/2016. Disponível em: $<$ http://www.valor.com.br/politica/4499760/americo-martins-deixa-presidencia-da-empresabrasileira-de-comunicacao>. Acesso em 26 jan. 2017

WEBER, Maria Helena. Nas redes de comunicação pública, as disputas possíveis de poder e visibilidade. In: Comunicação pública e política. Pesquisa e Práticas. Florianópolis: Editora Insular, 2017.

ZANATTA, Carlos Eduardo. Hélio Costa debate TV pública (ou estatal) na Câmara. Tela Viva, publicado no site do FNDC. Disponível em <http://fndc.org.br/clipping/helio-costa- 
debate-tv-publica-ou-estatal-na-camara-145312/>. Publicado em 29 fev. 2007. Acesso em out. 2016 


\section{APÊNDICES}

APÊNDICE A - DIANA DIAZ SOTO, atualmente, diretora/coordenadora da Señal Colômbia. Na data da entrevista, 17 de novembro de 2015, era coordenadora ela do Proyecto de Comunicación, Cultura y Niñez del Ministerio de Cultura en la Dirección de Comunicaciones (2015).

\section{Hable sobre la estructura de la Señal Colombia y su vinculación}

RTVC que es la Radio Televisión de Colombia - Sistema de Medios Públicos y a su vez Señal Colombia y RTVC está mas en la organización del Ministerio de las TIC (Tecnologías de la Información y la Comunicación) pero en la junta directiva de Señal Colombia y del comité Pronación (Programación?), tienen asiento también el Ministerio de Educación y de Cultura.

En la parte de la junta directiva digamos que es el órgano de RTVC en el que se van guiando las decisiones que se toma la gerencia y en el comité de Programación es mas un organismo de vigilancia, es mas de consulta, como una instancia consultiva de las decisiones de programación que se toma la Señal Colombia.

\section{Sabes si sufre de intervenciones gubernamentales, hacen presión política?}

Sí, claro. En Señal Colombia, eso va a ser una respuesta compleja, desde el 2004 cuando fue creada RTVC, se liquidó Inravisión. En ese momento yo fui una de las productoras delegadas pioneras que entró, bueno, entramos, como a hacer propuestas en términos de acompañamiento de producción de contenidos que en ese momento se habían licitado a realizadores independientes, pero luego comenzamos a ser lo productores delegados: una instancia importante en la definición de contenidos y estrategia de programación. Estuve por seis (6) años en el momento en el que Señal Colombia inicia bajo RTVC y se crea esta figura de productor delegado porque Señal Colombia (Pausa para atender alguién- interrupción)

Te estaba diciendo que Señal Colombia existía en Inravisión, que era el Instituto de Radio y Televisión de Colombia. Ese Instituto ha comenzado un momento en que, sugestionado por varios años en que se sindicaliza, pero se sindicaliza mal, o sea, se sindicaliza por el lado en que todos los sindicatos comienzan a hacer más difícil la operación y decae la calidad de los contenidos.

¿Y eso en que año? 
Eso empieza a suceder en los años 90. Entonces claro, llega un gobierno que decide: "no, liquidamos Inravisión, creamos RTVC, y lo pasamos a Señal Colombia”. Digamos que en términos legales pasamos a Señal Colombia y a la Radio Nacional también. De Inravisión a RTVC y en ese momento los ministerios de Cultura y Educación, junto con el Ministerio de las TIC, en ese momento se la juegan por revolucionar de alguna manera la programación, los contenidos.

\section{¿Esto en que año fue?}

Esto en los años de 2003. Hay un antecedente que es importante: entre el 1999 y el 2000, alguien que está muy cerca de la presidencia de Inravisión, Nicolás (..?), que entre el 1999 y el 2001 fue asesor de la presidencia, se monta la tarea de diseñar algo que se llamó el Proyecto de Educación y Cultura en Medios - el PROCEM. Y el PROCEM resultó ser un proceso de formulación súper bonito. ... Te decía que entre el 1999 y el 2000 se comienza a formular algo que se llamó el PROCEM, que fue el Proyecto de Cultura y Educación en Medios. Fue un trabajo muy interesante de formulación de un proyecto colectivo, porque se crearon mesas de trabajo mixtas, donde había gente de las entidades gubernamentales y de ONGs para tratar temas específicos. Yo lideré la mesa de Educación Inicial, o sea, la de los contenidos infantiles. Había allí gente de radio, de la tele, de algunas organizaciones, del Ministerio de Educación, y diseñamos y formulamos un proyecto. Todos esos proyectos que se formularon en cada una de las mesas de trabajo significan el PROCEM. Y el PROCEM tenía una gran ventana, o una gran sombrilla que hablaba como de los enfoques de la televisión educativa y cultural que aún se mantienen, como TV para la convivencia, diversidades culturales... todo eso se formuló desde el PROCEM. Lo que pasó en ese momento, que también fue uno de los detonantes para que se desapareciera Inravisión, fue que la formulación estuvo muy bien pero en el momento de la ejecución Inravisión aisló a todas las organizaciones que participamos en la formulación de los proyectos y comenzó a ejecutar el proyecto por sí sola. Y en el camino, eso se quedó. Porque sacan las convocatorias, ya la gente empieza a participar, y no se supo nunca con qué criterios seleccionaron los contenidos.

\section{¿Tú no conocías a nadie?}

No. Y lo que pasó es que la gente presentaba una propuesta, les daban la plata, entregaban unas "latas", unos proyectos, unos programas y nadie sabía si eso realmente correspondía a lo que se había otorgado. Entonces eso también detonó como... acelerar el proceso de acabar con Inravisión y de pasarla a RTVC. Se queda RTVC y en el momento entonces el Comité en el que estaba sentado el Ministerio de Educación y el Ministerio de Cultura y el Ministerio de 
las TIC decide implementar la figura de productor delegado, que es esta figura de una bisagra o un enlace entre los realizadores independientes y el canal, entre el canal y los realizadores independientes. $\mathrm{Y}$ en ese momento hacen un concurso muy grande para buscar personas con experiencia en TV y elegir los productores delegados, iniciales, los pioneros. En ese proceso de selección, gané yo una de las 6 plazas entre 60 y pico. Entonces comenzamos a trabajar en ello.

\section{¿Eso comenzó de forma muy democrática? Por que fue un concurso y no una indicación política?}

No. Fue un concurso que duró como un mes, pareció un reality. Había que hacer pruebas, juego de roles, cálculos, pruebas en línea con los EEUU...

\section{¿Y los que jugaban eran...?}

Los que participaban eran personas que, cuyo perfil, en el análisis de recursos humanos que revisaban el perfil, teníamos que tener experiencia en $\mathrm{TV}$, en coordinar proyectos con una mirada estratégica y conceptual. Y los que elegían eran como las cabezas de los ministerios, eran los asignados. No se volvió a hacer ningún concurso igual. Y luego comenzaron a entrar los productores delegados. Hubo un momento en que entraban por palanca, como se dice acá, porque tenían algún amigo político, pero lo que tiene particular ese rol es que si no cumples con el perfil, el mismo rol te expulsa. No lo puedes mantener porque o te parece que es burocrático o que hay mucho papeleo, que no entiendes, entonces esa gente que entra por palanca por lo general se va muy pronto, salvo que tengan una muy buena (fuerza)... y que no lo pongan para abajo, ¿no?, que pueda pasar de agache.

\section{¿Pero eso es raro, no?}

Sí, pasa muy poco. Entonces en 2004 nosotros asumimos como productores delegados y se liquida Inravisión, arranca RTVC y comienza esta lógica de que la programación de Señal Colombia se terceriza, el canal diseña unos términos de referencia donde establece las condiciones de lo que quiere en términos del contenido audiovisual específico, asignan un dinero y abren una convocatoria.

En esa convocatoria, ese proceso ha venido afinando en términos de cómo asignar esos recursos porque en el primer envión que se hizo en convocatoria, los jurados eran externos, y era gente de muchísimo conocimiento en TV pero la falta de apropiación del proyecto colectivo televisivo no permitía que eligieran cosas que realmente sirvieran al canal o que fueran incluso buenas, sino por capricho les parecía que eso estaba bonito. Entonces se llegó al final del proceso de convocatoria, y ya digamos que hay unos términos muy, muy, muy rigurosos y unos criterios de selección también muy rigurosos y ahí lo que se hace es 
conformar un jurado en el que participan un asesor del Ministerio de Cultura, uno del de Educación, algún productor delegado y productor ejecutivo de Señal Colombia. Entonces de ahí sale la selección de los proyectos. En donde se decía cuál era el perfil, las funciones, cómo se llevaba el procedimiento, del punto A al B, como sacar un proyecto que estaba en el papel y que debía convertirse en un contenido de calidad.

\section{¿Como una Biblia, un manual?}

Claro, como manual cumplía completamente ese rol. Luego, más adelante, ya con otro tipo de gente, incluso Marcela Benavides, escribimos el Manual General de Producción, que ya es como la gran biblia del canal donde están todas las reglas del juego, que propone el canal en términos de fases, equipos de trabajo, editoriales y de estilo, o sea hay una cantidad de consideraciones allí, es realmente un trabajo muy extenso y muy completo.

Entonces la pregunta sobre cuanto incide políticamente....

Cuando se creó RTVC, hubo una decisión que para Señal Colombia fue muy oportuna, muy buena, y fue que - hasta ese momento, en la frecuencia de Señal Colombia, la programación educativa y cultural se rompía, por ejemplo, con transmisiones del Congreso o con transmisiones del presidente. Cuando se crea RTVC, se dedican a Señal Colombia solamente los contenidos educativos y culturales y otro canal se llama Canal Institucional y todos los esfuerzos institucionales, el eco de los directivos y presidentes de esas organizaciones, se va por Institucional. Eso fue muy importante para Señal Colombia.

\section{¿En qué año fue creada Institucional?}

Fue abierta con RTVC.

Liana cuenta que ve la TV toda la noche, dice que le parece bueno que haya nombres diferentes...uno canal Institucional y otro para otras cosas en geral ...Diana está de acuerdo. Eso por un lado. La existencia del Institucional ayuda obviamente a que los temas políticos que inciden en los contenidos ya solamente se van por un lado que es Institucional, que digan lo que tienen que decir, y los contenidos educativos y de cultura se protegen. ¿Ahora, qué pasa? Desde mi perspectiva, desde mi punto de vista el hecho de que haya habido cierta permanencia en el proyecto comunicativo, educativo y cultural de Señal Colombia tiene que ver con el factor humano que se ha venido fortaleciendo en el mismo canal. Cuando yo estuve ahí, yo no tenía un cargo directivo, yo era una productora delegada contratista. Pero, con mis compañeros defendíamos mucho el Proyecto. Y comenzaron a crearse una red de protección del Proyecto, donde participaban los productores independientes. Ellos comienzan a ganarse los concursos, a producir contenidos, y se dan cuenta de que hay una forma narrativa y audiovisual de contar historias para Señal Colombia distintas a la televisión comercial. Y 
comienza a darse el interés de mucha gente que se quiere formar para estar en Señal y no porque no le dieron trabajo en RCN/Caracol. Y esa gente comienza a proteger también el proyecto colectivo, es lo que yo percibo. A pesar de que RTVC ha cambiado mucho de gerentes, su gente también, ha habido muchos cambios en los últimos años. Si un gerente alcanza 1 o 2 años en la dirección es mucho.

\section{¿Y eso impacta en la programación?}

Claro, impacta. Siempre van a querer hacer algo por su cuenta. Entonces, por lo general, lo que pasa es que terminan haciendo algún capricho, pero no pueden afectar toda la programación porque ya vienen con unos planes establecidos desde antes. Y eso ha sido porque está tan claro el Proyecto y, pues, porque ahí siguen estando el Ministerio de Cultura, de Educación, tanto en la Junta Directiva como en el comité de programación, que no permiten, que no es tan fácil salirse del...

Y lo otro es que en la rotación del equipo de trabajo (15'), este equipo de trabajo que lucha por proteger el Proyecto, ha habido como un proceso de formación y de sensibilización para que entre todos nos protejamos. Entonces, yo ya no estoy, desde el 2010 yo ya no estoy allí, entonces hace 5 años que no estoy allí. (Diana voltaria tempos depois)

\section{¿Pero lo sigues defendiendo, no?}

¡Claro! Desde acá, por supuesto. Yo sigo, por ejemplo, participando en las mesas de trabajo que hacen para Mi Señal, la franja infantil. O también he participado como jurado en el mercado de coproducción. Y ahí siempre, todo el tiempo, estamos protegiendo el Proyecto. Pero la gente que llega es gente que ya ha trabajado para Señal Colombia como independiente y que ya sabe para dónde va.

\section{Es una seguridad.}

¡Claro! Hubo un momento en que el Canal estuvo bastante acéfalo que fue hacia el 2009 particularmente, donde había un gerente interino, no se tomó la decisión de poner un gerente específico, incluso la coordinación de Señal Colombia, la persona que era la coordinadora no tenía una mirada estratégica muy profunda, sino que se dedicaba más a temas administrativos, entonces la mirada estratégica la ponía yo (risas). Yo asumí, digamos, fui contratada para ser asesora para los contenidos de programación de Señal Colombia. Entonces ya estaba asumiendo un poco la responsabilidad de los contenidos y la programación junto con el resto del equipo de productores delegados, en el que estaba también Marcela Benavides, y ahí como quedábamos en la lucha para que esta vaina no se cayera. Un cargo que es determinante es el de coordinador de Señal Colombia. Cuando hay coordinación de Señal Colombia que no comprende el Proyecto, eso se siente en pantalla, en algún momento. Para mí eso pasó en 
2010 cuando llegó un coordinador que tenía una perspectiva más de la TV comercial y se sintió, se sintió que no había como una fluidez de asuntos.

\section{¿Sale naturalmente o la gente lo saca?}

Llegado un gerente lleva a su equipo.

¿la gente sale?

Sí, las cabezas. Es como que está el gerente y naturalmente cambia el subgerente, no siempre el subgerente cambia al coordinador, pero muchas veces sucede. Como veníamos de una gerencia muy loca, muy rara, que ponen al subgerente que no se enganchó con el proyecto, cambió a su coordinador, que tampoco se enganchó, entonces se afectó, me sacaron a mí, hubo cambios radicales pero llegó otro gerente a recoger que ya sabía de televisión.

\section{¿a recoger el Proyecto?}

Sí. Dice "lo que ustedes vienen haciendo, no" cambia a su subgerente y él cambia al coordinador y pone a Marcela Benavides como coordinadora y ya, todos están felices porque Marcela es una persona (competente)...

¿Hoy el coordinador es Jaime?

Sí

\section{¿Jaime se alinea al Proyecto?}

Yo calculo que sí. Él viene del cine, no tiene mucha experiencia en TV, pero ha venido recorriendo la...

\section{¿él conoce Señal?}

Sí, sí. Y además escuchar al equipo. Eso es muy importante.

\section{Tener humildad y escuchar el equipo es lo más importante para el directivo.}

Yo creo que en la época de Marcela, el canal se consolidó enormemente porque logró consolidar un equipo de trabajo muy talentoso.

\section{¿Cuál fue la época de Marcela?}

Creo que del 2011 hasta comienzos del 2014.

\section{¿Ella que se quiso ir?}

Es que el cargo de coordinador es muy pesado. Marcela consolidó ese equipo, el Proyecto...

\section{¿Pero la sacó el presidente?}

No. Ella se fue por cuenta propia porque se saturó un poco. Ya le estaba afectando la salud. Porque claro, parte de lo que ella hacía, y que es una cosa muy valiente, para proteger el Proyecto del Canal, era proteger a su equipo.Y entonces todo lo negativo lo recogía ella, aislaba a su equipo para que ellos pudieran trabajar. Entonces se saturó porque siempre hay 
presión. Pero yo creo que lo que ha permitido que se mantenga algo del Proyecto es que hay gente que lo protege.

Creo que es importante crear una historia para que la gente lo continúe. La historia se hace cuando se trabaja con equipo, que hace la continuidad.

En resumen: siempre hay presión política, es así, pero Señal Colombia viene trabajando sobre un proyecto que se ha venido consolidando con el tiempo. Es muy difícil que desde la política - sola -, se destruya. Se necesita que haya otros factores. Porque ahora hay otros factores, como la convergencia, las multiplataformas, que están implicando al canal reformularse de muchas maneras. Apenas con la política es muy difícil que desaparezca el Proyecto como está porque, por ejemplo, franjas como Mi Señal han venido consolidándose ante los niños, ganan premios, eso.

¿Creo que hoy la tarea es conseguir audiencia, no? (Liana Habla de los juegos olimpicos nacionales, que los están transmitiendo).

Diana: La transmisión de deportes que no son fútbol es muy importante. Nos hemos enganchado con las Olimpiadas, Paralimpiadas, juegos nacionales, Panamericanos o con torneos como Patinaje, donde Colombia es potencia... es una oportunidad muy grande para enganchar. Ayuda mucho porque además se aprovecha para promover la programación tradicional, regular del canal. Entonces, sí, esa es una buena estrategia.

Vuelve a hablar de la audiencia de las TVs públicas. ¿Hacen divulgación? compiten con canales de pago.

Yo creo que con respecto a las audiencias hay varias cosas.

\section{Sí porque hay los publicos intelectuales que las ven...}

Creo que hay varias cuestiones de autocrítica que nos tenemos que hacer. Una es: claramente le falta mucha promoción, divulgación. Claramente eso también tiene que ver con que los recursos son insuficientes. O tienes recursos para producir o para promover, para las dos cosas no alcanza. Entonces eso es un gran problema. Segundo, es que yo creo que sí hacemos cosas muy lindas, representativas, pero todavía nos falta algo, un factor desconocido en lo narrativo que agarre al público más masivo, al público más general, al ciudadano de a pie. Que lo agarre y que lo enganche porque uno no se explica porque ese ciudadano se engancha con cosas en Discovery y no se engancha con cosas en Señal Colombia si hay unas cosas que incluso son mejores. Ahí hay un factor, que tiene que ver también con nuestra... el ciudadano común en Colombia tiene que tumbar el mito de que la tele pública es aburrida. Y por otro lado también tiene que ver con que hay una "doble moral" con respecto a algo que la audiencia dice que ve con lo que realmente consume. La audiencia dice querer ver más 
documentales, más TV constructiva, pero la verdad es que se pega a las telenovelas que son de los narcos, o de los cantantes que son polémicos, o a los realitiesy a eso es lo que le da marcación. Yo creo que hay otra dificultad ahí. Por un lado está la carencia de los recursos para promoción y por otro lado narrativamente nos falta un giro a la tuerca que no sé qué es para terminar de enganchar a la gente, que sientan que es de todos y que le den ese valor. Tres: nos falta trabajar más información de públicos para que la audiencia se enganche en los contenidos públicos. El otro factor es que no tenemos un sistema de medición que nos permita saber exactamente, que no sea el comercial.

\section{Son todas comprometidas}

Claro. Entonces nos hace falta un sistema de medición que nos diga en realidad qué tanto se está consumiendo toda la TV y no solo la TV pública porque además, de ese sistema que tenemos de TV pública que son regionales y Señal Colombia e Institucional, como tú ya sabes, también tenemos más de 500 señales comunitarias, que tienen otros alcances. Y de eso sí que estamos en pañales, desconocemos por completo su comportamiento. Aunque desde el Ministerio también hacemos un trabajo importante para intentar calificar algunas de esas señales. (26')

En Brasil, se hace una red con las regionales (EBC). Cuando cambia el gobierno de los estados que sea de un partido politico diferente, se cambia todo. En esto momento, la TV

Cultura de São Paulo que es de otro partido político, y tamién tiene una red.

Digamos que esas redes se establecen para proyectos particulares. Esa red no está permanente (en Colombia). Ella se activa para cosas específicas. O la activa la ANTV diciendo "a ustedes no les estamos preguntando sino que tienen la obligación de engancharse para tal señal en específico para un evento en particular", o algo así. O la ANTV, que es la autoridad, es la que impone, o ya para efectos como el que hicimos alguna vez entre Señal Colombia, las regionales y el Ministerio que fue una serie de coproducción que se llamó Hechos del Corazón. Esa serie está muy linda. Ya no está al aire. Sacamos 42 capítulos de 5 minutos. Cada canal ponía 5 capítulos de 5 minutos y recibía la serie entera pero lo bacana de esa experiencia fue que de principio a fin diseñamos el proyecto colectivamente. Se hizo el Manual de Estilo colectivamente. Me emocioné mucho cuando empezamos a recibir los capítulos y nos dimos cuenta que el de Telecafé se parecían a los del TRO y a los de Telecaribe porque, además, la mayoría de los regionales no tienen esa tradición de pensar el proyecto desde el para qué, sino que comienzan a hacer. Con Hechos del Corazón los llevamos a varias cosas, uno los llevamos a pensar un proyecto televisivo desde el principio. Primero el trabajo de mesa: escribir. Segundo que estructuramos narrativamente un proyecto 
colectivo, o sea, con necesidades narrativas de cómo solucionar una historia. Lo otro es que los obligamos a sacar las cámaras de sus estudios en las capitales más importantes de su región y también a que pusieran la cámara donde vive la gente.Porque eso algunos canales no lo hacen, hacen telesofá todo el tiempo.Y a que hicieran un trabajo de investigación en sus regiones buscando historias del cotidiano para que eso se diera. Entonces fue un proyecto muy bonito. Lo que pasa es que es un proyecto desgastante y volverlo a hacer ha sido difícil pero fue una experiencia muy rica. Entonces se activa la red en momentos muy específicos. Cuando se activa la red, a veces están todos los canales, a veces no están todos pero están los que siempre son más activos como Telecafé, Telecaribe, Telepacífico.

¿Señal hoy llega a todo el país?

Señal Colombia sí, llega como a 97\% del territorio y 95\% de la población. Estas son las cifras que tengo en la cabeza.(30min)

Liana Habla sobre el Consejo Curador en Brasil, nombrados por el presidente y otros. Consejo Administrativo formado por Ministros son los que deciden y no los curadores que representan los ciudadanos. Balanceo de los últimos 7 años de tv en el Seminario Conselho Curador - Criticas: falta de autonomía, independencia y la indicación de los directivos por parte del gobierno. Habla sobre vinculación Secretaria de Comunicación (Secom). Puerta giratoria. Y le pide a Diana que hable sobre su experiencia.

Aquí hay una ley que controla, que prohíbe la "puerta giratoria", es decir, yo por ejemplo fui durante unos meses Jefe de la Oficina de Contenidos y Defensoría del Televidente de la Comisión Nacional de TV. Terminado esos 6 meses yo no pude trabajar en ningún canal de TV por 2 años. No pude trabajar hasta que pasara una ventana de 2 años. Y ahora tampoco estoy en ningún canal, sino en el Ministerio, ¿no?

¿Te acuerdas de la ley?

Podemos buscarla rápidamente. (34'37)Es una ley que aplica a todos los sectores. (¿?)

Pregunta sobre cambios de los jefes), ¿cuánto tiempo te quedaste allá?

Yo estoy (o estaba?) hace 5 años como productora delegada y 1 año coordinando la parte de programación y contenidos del canal. Otra cosa que ha sido importante de todo el Proyecto de Señal Colombia es que tenemos criterios muy claros y fue un trabajo que vinimos haciendo, por ejemplo, para la compra de material de películas o de material internacional hay plantillas de criterios que se aplican a todos los títulos y que hay unos analistas/un productor delegado que se dedica a revisar eso y a aplicar esos criterios y no por capricho propio.Y además también se ha fortalecido el contenido de programación de pensar, de anticipar, una cosa que hizo Marcela, fue pensar temáticamente el canal en periodos, un tema anual para más temas 
mensuales, para más temas trimensuales, y planear con anticipación esos temas para orientar todos los recursos a que temáticamente se promoviera de esa manera. No significa que todos los contenidos sean sobre ese tema, sino que estratégicamente se orientara un énfasis temático para poder promover y cada vez más llamar la atención de las audiencias. Eso ha sido muy chévere. Hasta donde yo entiendo eso no se mantenido del todo. No me acuerdo que haya un tema en este momento.

\section{¿Qué consejos darías a Brasil para que se cambie eso de la indicación de un directivo por el Presidente? ¿Cómo se hace para que la sociedad tenga el poder de decidir eso?}

Me parece que la alianza entre la TV pública, particularmente Señal Colombia, y los productores independientes, que son los que quieren narrar el país, las comunidades, a la gente, desde sus propias inquietudes, esa alianza es muy importante. Eso es como lo primero que hay que hacer. Aquí, cuando los sectores se organizan, consiguen cosas. Por ejemplo, los cineastas, se han sobrepuesto a sus vanidades, egoístas, se sientan los artistas, los gurúes de los directores de cine y organizan una agenda y van y golpean la dirección de cinematografía del Ministerio y han sacado dos leyes, los cineastas. Una primera recomendación es que lleguen los realizadores independientes a criticarnos, chévere, pero lo mejor que puede pasar es que realmente sientan que esa voz que tienen puede decidir un asunto. Entonces, cómo fortalecer uno la alianza entre los productores independientes y las entidades, o sea, y el canal. De otra parte también es importante trabajar mucho la formación de públicos, más allá que la formación de públicos desde una perspectiva muy ingenua, es desde algo que yo le llamo "la autoestima como audiencia”. (39’31)O sea, el público se merece mejores cosas. ¡Que vean mejores cosas! Que vean cosas más chéveres, mejor pensadas, más dedicadas, con mayor inversión en la parte del diseño, en la parte del trabajo. El público se merece mejores cosas pero no lo sabe, por eso sigue viendo las porquerías que presentan en Caracol y RCN. Y también que haya conciencia crítica.

\section{En Brasil se hace mucha producción interna y aquí no.}

Aquí casi todo está tercerizado.

\section{¿Eso te parece bien?}

A mí me parece que sí, hay unas cosas que de pronto no necesariamente, porque hay que responder con mayor agilidad y tercerizarlo lo complica. Pero a mí me parece bien porque oxigena la pantalla, mueve más el sector, dinamiza más la creación.

\section{¿Trabajar con servidores públicos es complicado?}

Sí.

\section{La gente tiene que verse en la pantalla...}


Ahí es donde yo creo que está la gran crítica que nos tenemos que hacer nosotros, como colombianos, y es: teniendo cosas de tanta calidad, ¿por qué no resulta ser significativo para los colombianos? Y yo creo que es un asunto que tiene que recoger muchos eslabones en una cadena.Entonces, por un lado es que la política pública está orientada a fortalecer la TV y los medios públicos. ¡Yo creo que ahí falta! Yo creo que ahí faltan todavía más instrumentos de política pública que estén orientados a fortalecer. Luego, una organización institucional técnica preparada para responder a esa política pública y luego, un talento humano, que esté también formado, para comprometerse con ese Proyecto. Eso lo hemos hecho, a pesar de la carencia de la política pública. De hecho ahora están en curso como 4 proyectos de ley que buscan reformular un proyecto de ley del 2011 que quedó mal hecho, de TV, quedó mal hecha esa ley. Salió promulgada y todo. Fue la que acabó con la CNTV y creó la ANTV. Pero se quedó mal hecha. Una autoridad que no te raja ni te presta el hacha, o sea, no pasa nada ahí, y el contenido y la promoción y lo que hay que suceder, pues no pasa, ¿no? Eso por un lado. Yo pongo como ejemplo en algunos talleres que hago, si en este momento, por alguna razón, se acabara con Coldeportes en Colombia, que es la entidad pública que ha estimulado el deporte nacional y que permitió que en los últimos olímpicos nos hayamos ganado 11 medallas, eso fue como increíble, ¡la gente protesta, se indigna! Pero si en ese momento la TV pública se acaba puede que nos indignemos los mismos de siempre, ¿no?¿Entonces qué pasó? Hubo una suma de estos eslabones, ¿no? Una política pública, una institucionalidad técnica, preparada para eso, un talento humano, y una gente que respondió.Y, de ahí, la gente empezó a querer a los deportistas y a entender que no es solamente el fútbol, que hay otras cosas. Entonces yo sí creo que todavía estamos como que con una debilidad en política pública que hay que fortalecer. Pero, ¡mientras tanto, con lo que hay! Que, por ejemplo, si las estrategias establecen una alianza entre la producción independiente y el canal, y buscar maneras de ampliar, o sea, que la audiencia llegue más, meter a las universidades, por ejemplo, para los asuntos de investigación, para asuntos de formación de talento, eso es súper importante.

Fim.

Diana Díaz Soto - coordinadora del Proyecto de Comunicación, Cultura y Niñez del Ministerio de Cultura en la Dirección de Comunicaciones.

Fue productor delegado y productor ejecutivo. Ahora es la diretora de Señal

\section{Comlemento de mensagens pelo Messenger e por email}

Mensagem enviada para Diana Diaz no dia 23/11/2016

Ola Diana, 
Recuerdas la entrevista que hice con usted en el Ministerio de Cultura en el año pasado? Hicimos la transcripción, pero ahor usted está conduciendo la Señal, y esto es muy bueno. Estoy viendo a través de Facebook y la web las innovaciones. Pregunto se pudiera leer la entrevista del año pasado, si es posible y añadir información actual acerca de sus proyectos de Señal, como fue la invitación que recibiste para manejar el canal. Puedo escribir a su correo eletrônico? Abrazo, Liana

\section{Resposta de Diana recebida pelo Messenger, dia 28/11/2016}

Hola Liana. Qué bueno saber de ti. Ya respondí tu mensaje pero hay una parte de tu pregunta que te respondo por acá. La invitación original fue a coordinar la franja infantil Mi Señal y seguir también vinculada con el proyecto de niñez en el Ministerio de Cultura. Al mes haber iniciado renunció el director del canal, abrieron un proceso de convocatoria y me presenté. Felizmente quedé seleccionada. Ahora la idea es fortalecer y evolucionar nuestros módulos de programación: infantil, ficción, no ficción, deportes. Quedo atenta a cualquier duda. Un fuerte abrazo

Hola querida Liana,

Muchas gracias por tus palabras. Sí, somos conscientes que la situación de los otros canales de la región está muy complicada. Por lo que veo en la transcripción todo está acorde con lo conversado.

Con respecto al presupuesto, la ANTV asigna a Señal Colombia un total aproximado de 18 mil millones de pesos, que vienen siendo 6 millones de dólares que está destinado para producción, programación y promoción a través de autopromos y entornos digitales.

Nuevamente muchas gracias por tu deferencia y continúa siguiéndonos en Facebook que tendremos cada vez más novedades.

Un fuerte abrazo 


\section{Liana Milanez<limilanez@gmail.com>28 de abr}

para Diana

2017-04-17 19:33 GMT-04:00 Diana Díaz Soto

Hola Liana,

Perdona la tardanza en responder. Estaba en vacaciones. Te respondo cada cosa:

1. Sí, es comité de programación. Seguro hablé muy rápido.

2. No te envié ajustes porque vi todo en orden en la transcripción original.

3. Claro, mándame las preguntas de programación y te respondo.

Muchas gracias y un fuerte abrazo.

2016-11-28 11:50 GMT-02:00 Diana Díaz Soto <ddiaz@,rtvc.gov.coddiaz@,rtvc.gov.co>:

Hola querida Liana,

Muchas gracias por tus palabras. Sí, somos conscientes que la situación de los otros canales de la región está muy complicada. Por lo que veo en la transcripción todo está acorde con lo conversado.

Con respecto al presupuesto, la ANTV asigna a Señal Colombia un total aproximado de 18 mil millones de pesos, que vienen siendo 6 millones de dólares que está destinado para producción, programación y promoción a través de autopromos y entornos digitales.

Nuevamente muchas gracias por tu deferencia y continúa siguiéndonos en Facebook que tendremos cada vez más novedades.

Un fuerte abrazo

El 23 de noviembre de 2016, 12:39, Liana Milanez $<$ limilanez@gmail.comlimilanez@gmail.com>escribió:

Hola

Diana,

¿Todo bien? ¿Cómo se va Señal Colombia? Yo sé por Facebook las innovaciones web que usted ha hecho. El año pasado, cuando hablamos estabas en la dirección de Minsitério de Cultura Comunicaciones. Y habló con gran afecto de la Señal y continuó trabajando para el canal. Al participar en todos los procesos de reestructuración Señal Colombia en la década de 2000, su regreso a dirigir el canal es muy importante y muy bueno para el televidente. 
Aquí en Brasil la situación de la televisión pública es muy difícil. TV Brasil - EBC está experimentando cambios profundos, con muchos despidos y salidas. $\mathrm{Y}$ en el sur de Brasil, en Rio Grande do Sul, la crisis económica del estado está dando lugar a la probable cierre de la televisión.

Envío la transcripción de la entrevista que hicimos en el último año para su revisión. Por favor, ver si es correcta, si es necesario alguno ajuste. También me gustaría saber acerca de Señal hoy, proyectos y otras informaciones que le parezca importante .

El año pasado, Jaime pasó algunos datos sobre el presupuesto que Señal recibe de ANTV. ¿cuántos de estos fondos se invierten en la programación? Y en qué se define la cantidad?

Fuerte abrazo,

Liana 


\title{
Mensagem gmail
}

\author{
Diana Díaz Soto <ddiaz@rtvc.gov.co> 28/11/2016 \\ para Liana
}

Hola querida Liana,

Muchas gracias por tus palabras. Sí, somos conscientes que la situación de los otros canales de la región está muy complicada. Por lo que veo en la transcripción todo está acorde con lo conversado.

Con respecto al presupuesto, la ANTV asigna a Señal Colombia un total aproximado de 18 mil millones de pesos, que vienen siendo 6 millones de dólares que está destinado para producción, programación y promoción a través de autopromos y entornos digitales.

Nuevamente muchas gracias por tu deferencia y continúa siguiéndonos en Facebook que tendremos cada vez más novedades.

Un fuerte abrazo, Diana

Aquí las preguntas para usted evaluar

Me gustaría que hable de lo que cree que es más importante acerca de Señal.

En Señal Colombia lo que más importa es mantener y evolucionar un proyecto de televisión pública dirigido a los ciudadanos y no a los consumidores, que no intenta vender nada, sino que busca ser reflejo de la identidad de los colombianos, además de ventana que mira hacia el mundo.

En cuanto a la parrilla de programación, como se hace la distribución de los programas? Vi en el sitio web que usted tiene una división temática muy interesante sobre tipo de programas, por generos, temática etc.

Cada mes tiene una temática particular, por ejemplo, en marzo fue el machismo mata, en abril colombia se escribe y en mayo todo lo que podemos ser (lanzamiento de la nueva premisa de canal). esto se planea desde el año anterior.

\section{Distribución del tiempo de la parrilla, horas / dia para el siguiente:}

Infantil - desde las 6:00 a.m. hasta las 7:00 p.m.

cine - películas - familiar al medio día de lunes a viernes y fines de semana por la tarde (cine tamaño familiar) y películas para público adulto todas las noches a las $10 \mathrm{pm}$ (en cine nos vemos)

documentales - series y unitarios documentales en el resto de los horarios (prime time entre semana y fines de semana

otros - especiales culturales y deportivos (deportes distintos al futbol profesional masculino ciclismo, natación, microfútbol, entre otros, festivales de música, de literatura, de danza) 
Los valores de producción en promedio?

Depende mucho pero hablamos de, en promedio 40 millones de pesos por media hora.

Número de programas producidos en co-producción o producción independiente por año transmitido por la Señal?

No tengo el dato exacto ahora.

Acerca de la información periodística, noticieros, ¿qué te parece? habría interferencia política si tenían noticias?

Tenemos una norma que nos impide hacer programas de opinión y noticieros.

Y las tasas estimadas de las audiencias? ¿Como esta? Debe haber aumentado en los últimos años, imagino, por la calidad de la programación.

La verdad, Ibope no nos hace justicia, estamos en 0,8 de rating, pero sabemos que el universo ibope responde a intereses comerciales y que no penetra donde está nuestro público.

Los proyectos futuros?

Estamos estrenando slogan. Pasamos de "todo lo que somos" a "todo lo que podemos ser". Es implica nuevos desafíos. Con la franja infantil estamos representando cada vez más niños colombianos en pantalla, así como contar con los mejores contenidos infantiles de todo el mundo que no necesariamente se encuentren en los canales de cable.

¿Sufre presiones y interferencia política, tiene autonomía e independencia?

Por lo general, no.

?Lo que piensa y cómo ve el futuro de la televisión pública?

Es un proyecto que debe expandirse a lo digital. en lo digital lo público debe conquistar nuevos terrenos

Muchas gracias y te mando un fuerte abrazo. Diana 
APÊNDICE B - PROFESSOR OMAR RINCÓN - Profesor Asociado y Director del Ceper. Ensayista, periodista y analista de las relaciones entre medios, cultura, política y tecnología. Crítico de Televisión de El Tiempo. Consultor en comunicación para América Latina de la Fundación Friedrich Ebert de Alemania. Profesor invitado en Argentina, Chile, Uruguay, España, Puerto Rico, El Salvador y Ecuador.

Gravado dia 17/11/2015

Local: CEPER - Facultad de Artes y Humanidades - Universid de Los Andes

\section{Por favor, identifíquese}

Mi nombre es Omar Rincón

He acompañado sus ideas sobre televisión pública, observado Señal Colombia, y hoy en Brasil me incomodan las discontinuidades de los medios por la política (cargos directivos nombrados por presidente e ministros - TV Brasil- EBC vinculada con la Secretaria de Comunicaciones de la República)... ¿Qué caminos tenemos y cómo hacer para que se cambie eso? (el formato, la falta de autonomía y independencia...) Según su visión de Señal Colombia (que no está tan vinculada al gobierno).

Le voy a hacer como una introducción. En este punto, a este momento, yo creo que la televisión pública en América Latina y en el mundo y en Brasil es un fracaso. Yo creo que la televisión pública no funcionó y no está funcionando. Y no funciona y no está funcionando por múltiples razones. Una razón es que nunca ha podido ser autónoma e independiente de los gobiernos. O sea, no ha podido ser las voces, los relatos, las imágenes de los ciudadanos sino del gobernante de turno. Entonces, tanto en Brasil, por lo que tú me cuentas, como en Argentina, como en Bolivia, como en Colombia, como en España, como en toda parte, cuando ingresa un nuevo gobierno, cambian los directivos. Y al cambiar los directivos, se cambia la orientación de producción de contenidos, de formatos y de estilo de cada televisora o cada radio, o cada medio público. Entonces, creo que esa autonomía que nos venden como modelo $\mathrm{BBC}$ nunca ha existido ni siquiera en la $\mathrm{BBC}$ de Londres. $\mathrm{O}$ sea, que eso no es tan cierto que exista un proyecto claramente público como se quiere pretender. Entonces me parece que ese es el primer factor. No hay televisión pública ni medios públicos porque hay demasiada injerencia de los gobiernos en la gestión, programación de contenidos y diseño de los canales.

Lo segundo que pasa es que normalmente la televisión pública ha sido equiparada a que es... igual a televisión cultural y educativa, y creo que eso es un error, porque una cosa es la televisión educativa, otra cosa la televisión cultural y otra la televisión pública, porque lo 
público no es educar y culturizar, sino el escenario de la ciudadanía y la diversidad cultural y la pluralidad de opiniones, es la televisión de la gente... y si es televisión debe ser entretenimiento.... O sea, se debe hacer televisión de calidad, y eso no significa cultural y educativa, y que sea solo documental. ¿Por qué siempre tenemos que educar a la gente o tenemos que culturizarla? Educar y culturizar al pueblo es un acto de soberbia de los ilustrados y que creen que son cultos y educados. Se olvida que lo que hay que hacer es televisión, en el ritual televisivo, o sea ese espacio de relajación cotidiana que todos habitamos cuando prendemos la pantalla. Y por hacer educación y cultura, lo último que se hace es televisión. Primero hacen cultura, o primero hacen educación, pero lo último que hacen es televisión. Y al no hacer televisión se olvidan de que la gente, lo que "entra" es a ver televisión (relajación, reconocimiento, entretenimiento), no a educarse y no a culturizarse.

El tercer punto, de por qué ha fracasado, tiene que ver con que... como depende de los gobiernos no tiene políticas de gestión televisiva, sino de gestión política o de institución gubernamental. O sea, no se gestiona como un canal de televisión. Un canal de televisión se gestiona técnicamente, a largo plazo, o sea, no puede cambiar cada dos años, cada año de directivos; sino que se programa en tecnología, en programación, en contenidos, en proyectos, en modos de contratar por propuestas de calidad. Cuando se vuelve gubernamental, entonces para hacer un contrato te demoras un año, el programa que pensabas que te ibas a demorar haciéndolo 6 meses te demora tres años, la burocracia te mata. Y es lo mismo contratar un programa de televisión que un puente, o que una casa o que un edificio, o que una carretera o una rúa. Entonces, ese modelo de gestión atenta contra a televisión. A mí me gusta una idea tuya, te contrato y hacemos el programa de televisión, y con cada proyecto se evalúa su continuidad o no.

$\underline{Y}$ el cuarto punto por lo que ha fracasado es que está dedicada básicamente a un proyecto político sobre todo de carácter periodístico, "jornalístico". Y entonces resulta que a la televisión pública, el "jornalismo" le ha hecho mucho daño, porque los periodistas y políticos solo entienden una sola forma de hacer televisión, que es los informativos, los documentales y no entienden que la televisión es diversidad de formatos. Entonces, creo que siempre que los “jornalistas" manejan la televisión pública la vuelven una cosa de noticias y resulta que la gente está aburrida de noticias. No quiere ver noticias más en su vida. Y menos de propaganda del gobierno. Entonces es como crear una cosa de círculo propio para ellos.

En medio de todo eso, hay que asumir y quitar una mentira, o sea, ya no mentir más y decir: “como no puede ser independiente, no puede ser autónoma, no se puede hacer televisión, no se puede hacer buena televisión si no que lo que toca hacer es propaganda política, pagar 
favores políticos, dar empleo político". Pues lo mejor sería asumir que es una televisión gubernamental y olvidar la televisión pública. Asumir que somos gubernamental - y está bien -, porque siendo gubernamental tu le puedes exigir que tenga coherencia con el programa o plan de gobierno. El problema de lo público es que... se adueñan los gobernantes.

\section{¿Pero no es como el Institucional aquí?}

Sí... como es gubernamental está a favor del gobierno. Pero tú le preguntas - usted es del PT vea su televisión como es de mala, con respeto a ustedes, el PT. Ustedes dicen que tienen un país con prosperidad, pero la televisión no está diciendo eso. Pero en el momento en que es pública es como una cosa neutra, higiénica, que no es de nadie, que no es ni del partido político, ni del presidente de la república, ni del gobierno, ni de los ciudadanos, ni de los periodistas, ni de los de cine, ni de los realizadores. Es como que nadie se hace dueño de la televisión pública por ser una cosa pública. Lo publico termina siendo lo de nadie. Visto de ahí, entonces, todas las televisiones de América Latina tienen el mismo problema. En Colombia es lo mismo, o sea, el presidente de RTVC, que es la Radio y Televisión de Colombia (em 2015) era un tipo que era periodista de un canal privado y que luego fue el jefe de comunicaciones del presidente.

\section{¿Es Jaime Tenorio?}

No, Jaime Tenorio es el director de Señal Colombia, pero encima de él hay una burocracia que es como la de TV Brasil. Ahí está Radio y Televisión de Colombia (RTVC), luego está Señal Colombia, Señal Institucional, Radionica, Radio Nacional de Colombia debajo de eso... Entonces, es como eso. Los directivos ahí (RTVC) son totalmente puestos por políticos, nunca nombran una persona que sepa de televisión, nunca nombran a nadie que sepa de lo público, nombran gente que pertenece al grupo de ellos...entonces corresponde a la misma lógica de Brasil y de toda parte, que es una lógica política, no una lógica televisiva, una lógica burocrática, no una lógica de concepto. (\#00:08:38-5\#)

\section{¿Cuál es la diferencia que de alguna manera tienen Señal Colombia y Argentina, que están yendo en una cosa muy buena? Pakapaka...}

Es que Colombia tomó una decisión que ya Brasil la tenía antes y se la quitaron, que era: a los políticos les dejamos un canal, entonces hay un canal que se llama Señal Institucional para que ellos crean que eso les sirve de algo: una mala televisión que no ve nadie pero alaba el ego de los políticos. 


\section{En Brasil era Radiobras.}

Exacto. En eso que hagan lo que quieran los senadores, los políticos, y la otra Señal se deja para la cultura y la educación. Entonces, resulta que a los políticos, mientras no haya información, mientras no haya noticieros, journals, no les interesa la televisión publica. La dejan libre. Dejan hacer porque piensan que eso no lo ve nadie ni les da imagen pública; como no les interesa, pues no les importa. Los políticos son muy cortos de mente, piensan que todo sirve solamente para evangelizar, propagandizar e informar. Y cuando los intereses políticos desaparecen se pueden hacer cosas muy de calidad televisiva que fue lo que pasó con Pakapaka y con el canal Encuentro, allí no hay informativo, ni jornalismo. Lo mismo con Señal Colombia que ha tenido la fortuna de ser un canal que, como no hace periodismo, no hace jornalismo, nadie se mete con él, entonces pueden hacer una gestión un poco más autónoma, que es donde estaba Marcela Benavides, Diana Díaz, ahora está Tenorio. Entonces ellos han logrado hacer una gestión mucho más independiente y dedicada, con muy poco presupuesto logran hacer televisión de calidad, poca pero de calidad. Entonces ellos han logrado tener un poco más de autonomía. Pero obviamente una autonomía relativa porque mientras se dediquen a hacer diversidad cultural, hablen de temas que no molesten el poder, hablen de indígenas, de niños, de negros - no vamos a decir nada de la corrupción, de la inequidad social colombiana, no vamos a decir nada de las violencias que nos habitan, no decimos nada de lo malo... porque eso no se puede tocar... Entonces ellos se dedican a tratar temas que son importantes para la identidad pero que no son, a la final para el televidente cotidiano, al punto de tener poca importancia para los ciudadanos.

Hacen buena televisión, muy buena, pero como el presupuesto de ellos no es muy alto, es una televisión anti televisiva. En dos sentidos. Es una televisión en que se produce muy poco. Entonces ellos hacen programas con que ganan premios internacionales y todas esas cosas. Pero hacen 10 capítulos de una serie y la televisión es 24 horas, entonces el televidente colombiano no ve Señal Colombia porque nunca sabe qué están pasando ni a qué horas lo están pasando. O sea, no hay una conexión entre lo que ellos hacen y la gente. Y esta falta de conexión se debe a dos cosas: una, a que no hay una producción estilo televisiva, de tener 50 capítulos, de tener unos rituales._No los tienen, hacen todo muy pequeño. Y lo segundo, es que a pesar de una estética muy buena, televisivamente bastante buena, me gusta, es una estética muy letrada y clase media. A mí me gusta, pero a mí mamá no le gusta. Mi mamá me dijo un día: "es que eso es como un restaurante donde venden una comida que no es para mí". Entonces es como si fuera una televisión para nosotros del mundo civilizado y letrado y no una televisión para el pueblo. Pero, ¿y no es publica? Entonces creo que el gran déficit 
(11:59) de la televisión pública de calidad - Canal Encuentro, Pakapaka, TV Brasil, TV Cultura, todos esos canales -, el gran déficit es cómo hablarle al pueblo. Porque le estamos dejando el pueblo a Globo, a Televisa, a Caracol, a Canal 13. Tenemos muy buenos contenidos y muy buena televisión pero no está en los códigos culturales estéticos narrativos de la gente y lo popular; por eso, el televidente no se reconoce en esa calidad. Entonces de alguna forma estamos despreciando a la gente porque no estamos llegando a ellos, que es realmente lo que nos interesa. La regla de oro de la comunicación es el reconocimiento. Por eso "yo veo la televisión que me genera reconocimiento, identificación, lugar en el mundo". Como no me reconozco ahí, me reconozco más en los reality, en las novelas de TV Globo, y no me reconozco en la TV Brasil. Este es el asunto: la tv publica puede ser una televisión bien hecha, pero no hecha para el pueblo; una televisión hecha por gente que no ve televisión, sino para que otros vean. Entonces, hoy en día en América Latina las televisiones públicas que funcionan son las que no hacen jornalismo, no se meten con eso, las que se dedican a los niños porque el público infantil es exitosísimo por calidad, por audiencia y por reconocimiento. Y porque, además, hay una lucha cultural muy importante; Pakapaka está luchando los imaginarios culturales de Disney, desde Argentina, lo cual es muy interesante, y además pelea desde conceptos locales con una televisión internacional. Entonces, yo creo que es claro que el modelo de televisión como está hecho fracasó. Creo que Brasil hizo la inversa. Brasil tenía un sistema de televisoras diversas con las cuales... cada una intentaba hacer algo y cuando una estaba bien, la otra estaba mal, pero estaban como balanceadas, entonces tienes la televisión educativa, tienes la TV Cultura, entonces todo eso. Y cuando juntan todos, asumen el problema de las televisiones públicas de América Latina, que es una decisión política y no una decisión televisiva, ni comunicativa. Y creo que lo que está mal no es tanto que estén juntas, lo que está mal es que no hay un concepto de comunicación pública, no hay un concepto de seducción televisiva, no hay un concepto de hacer televisión de calidad, sino está más detrás de hacer un concepto de propaganda política, de educación y de información. Y lo otro es que es un lugar de empleo, de corrupción política también. Porque le da empleo a mucha gente que no tiene ni idea.

En Brasil la mayoría de las producciones son hechas internamente, se hace un concurso público que entran jóvenes que no tienen una mínina idea porque no tienen formación en televisión publica y los cargos directivos se quedan con las indicaciones políticas. Hoy (noviembre 2015) la televisión en Brasil está en huelga porque se reclama que no tuvieran ajustes de salario, que los cargos de confianza que son como 287 , los salarios 
son altos, el presidente de la televisión gana como 29 mil reales y los chicos que entran ganan 2 mil y poco y los jefes ganan 9 mil (minimo). He visto que los temporarios llegan, cambian todo y salen y los permanentes continúan en medio a ese cambio todo. Diana me ha dicho que aquí todos son por producción independiente que hacen un concurso (convocatórias) y selección, qué te parece que funciona mejor, trabajar con producción independiente o quedarse con 3 mil funcionarios?

Manuel Castells decía en su libro La sociedad de la información que el modelo de trabajo del futuro era la televisión y lo decía porque la televisión trabajaba para ser eficiente por proyectos no por empleados permanentes. Porque era un oficio que dependía de la creatividad con lo cual no podía tener funcionarios...

\section{En eso la Señal está bien...}

Eso era la idea, entonces eso haría que para el dinero que hubiese para invertir se invirtiera el $90 \%$ en hacer TV y el 10\% en gestionar la televisión con lo cual la inversión se va directamente a hacer la televisión. Lo que pasa en la mayoría de canales públicos incluído Señal Colombia es que la mayor cantidad de dinero se va en la burocracia y no en hacer televisión. En gente que trabaja para la televisora pero que no hace televisión. Los 'funcionarios/establecidos' se ganan la mayor parte del dinero, y los presupuestos para los productores independientes y para la gente que hace televisión, los realizadores, los roteiros, el director, es mas bien poco.

Señal Colombia intenta ser un modelo de producción independiente, pero sigue siendo muy pesado para actuar, tiene presidente RTVC, director de Señal Colombia, director Señal Institucional, director de esto... productores de contenido, productores delegados, productores de campo... entonces, todo es muy pesado... todavía la estructura hace que se gaste mucho dinero en la gestión y menos en la producción. Aunque es producción independiente, el hecho de que todo sea por concurso, crea un modelo más o menos perverso porque ganan los concursos los que cobren menos (las grandes empresas) y se hacen producciones de poco dinero. ¿Es bueno que sea por concurso? sí. ¿Es bueno que sea ser independiente? Sí. Muy bien, pero resulta que en televisión hacer un concurso para hacer 4 programas no es bueno, no es industrial, llaman a hacer concurso (convocatoria) y el total es 1 millón de dólares, con eso dan 20 proyectos entonces yo presento y por 20 mil dólares me toca hacer 4 capítulos, no es negocio, no es televisivo, ni industrial. Si en cambio tuviera que hacer 50 capítulos, de pronto los puedo hacer a 5 mil dólares capítulo pero tengo 50 para hacer; entonces, creo que está bien el principio pero no la ejecución porque nadie independiente se puede presentar porque no te 
conviene, no es buen negocio. ¿Quiénes se presentan? Las empresas que ya tienen un gran aparato, que todo les va a sumar y que todo ingreso importa; así casi siempre terminan ganando muchas empresas que son las mismas de siempre porque tienen la tecnología, el saber y no permite que gente joven entre, que experimente.

Pero creo que Señal Colombia y Canal Encuentro buscan que la producción sea independiente. Encuentro no tenía ni estudio, ni sala de edición, ni nada, era un canal donde tú llegabas y había una cámara y una sala de edición para promociones.

Señal Colombia, es otra cosa, ya tiene doble problema porque hacer producción independiente pero ya tiene estudios, cámaras, un equipo pesado de gestión y un equipo lento de producción. Entonces el equipo pesado, como hay un estudio, tiene que hacer mucha producción en directo, que son programas de estudio, que no son muy significativos. La idea es quitarle peso a la burocracia y darle más importancia a la producción independiente, que es lo más importante.

\section{¿Ese sería un camino para una televisión pública?}

Sí, totalmente. Yo me imagino que una televisión pública es: un gerente y, para cada franja tener un productor creativo y el resto independiente. Lo que yo imagino es: yo te nombro directora del canal - tengo alguien del financiero, alguien de jurídico, alguien de contenidos y programación. Y divido la programación por ocho franjas - 6h a las $9 \mathrm{~h}$ de la mañana, entonces te nombro a ti productora general de esa franja; le nombro a una persona que sea de realización para que piense en lo estético, y otra persona que sea de mercadeo. (22:20). Entonces ustedes tres van a gestionar ese pedazo del canal, de 6 a las 9 de la mañana. Otros tres de 9 a $12 \mathrm{~h}$, otros tres y así por delante. Y ustedes contratan a la gente que necesiten para llenar eso. Y cada 6 meses yo evalúo si el rating está bien, si la calidad está bien, si el mercado está bien.... Saco a los tres en caso de que no funcionen bien. Entonces, al final, en el canal seríamos 20 personas, y los demás, sería por producción independiente con lo cual se cumple con lo que es lo propio, estimular la producción, estimular la diversidad, crear talentos nuevos. ¿Sería algo de lo que se habría que buscar, no?

Creo que aquí, como en Brasil, en la TV Globo, la gente está allá desde hace mucho tiempo, empiezan una carrera y van lejos.

Sí, pero no tiene competencia, cuando no tiene competencia puedes hacerlo. El problema es que si Globo tuviera competencia, tendría que innovar, como no la tiene, ¿por qué tendría que innovar? Como pasa con Caracol en Colombia, Televisa en México, Clarín-Canal 13 en 
Argentina. Cuando tú eres monopólico, tú no tienes que innovar porque tú vas a sobrevivir tranquilamente. Me contabas de Globo que están yendo con cosas digitales pero no están muy preocupados porque... invierten mucho en tecnología eso sí, y hacen internet y algo de transmedia, por si acaso... pero el negocio va bien en lo de siempre, el negocio está bien como está, no es necesario buscar donde no está. ¡Los jóvenes están en internet y en el celular! Sí, pero el negocio se maneja por otro lado: por la pauta, la influencia política... y los jóvenes nunca han visto la tele.

\section{Hablas que hoy hay el conflicto de pantallas, me acuerdo de una conferencia que hizo sobre ese tema (...) .}

Creo que la otra gran revolución de la televisión pública, de los medios públicos es lo que yo llamo de las ciudadanías celebrities, que es que los ciudadanos se tomen las pantallas, las radios, no hace falta que seamos los expertos que aparecemos y representamos a los otros. Hoy, la gente, por culpa de los teléfonos celular y muchas otras cosas, tienen la posibilidad de tomarsen las pantallas y de existir allí. Eso es algo clarísimo, que la gente tiene el derecho y la posibilidad de meterse en las pantallas. Que hoy, el éxito sería que en Brasil la mitad de la programación fuera hecha por las personas.

Todo el mundo va a poner, televisión barata, baratísima, porque las personas van a mandar lo que tienen y como quieren ser y con los recursos que tengan. Y cada ciudadano se va a volver una celebrity porque va a estar en las pantallas. Su autoestima va a crecer, su manera de pensar, lo mismo. (26:00) Lo mismo en la radio: ya no habría porque tener tanta gente trabajando allá - ¡que la gente venga y haga el programa de radio como quiera! Que la radio sea de la gente. Creo que eso es lo que tiene que ser lo público, ya romper con que el público es un contenido de educación, un contenido de cultura y que la gente se tome las pantallas. Si lográramos eso, mira como que... creo que el aspecto que va a permitir eso cambiar. Y eso es ejercer la lógica del reconocimiento.

Y hacemos al contrario: la pasamos comprándole a CNN, a Fox, a BBC, a Discovery, a todos, como si ellos fueran los que saben - y no saben, porque no saben de nuestras culturas! Cada vez la comunicación se parece más con la forma de hacer y ser cultura local. El caso brasileño es único, pero es cierto que el que revolucionó a la televisión brasileña fue Glauber Rocha. Y Glauber Rocha la revolucionó sacando la cámara a la calle, haciendo un relajo, yéndose ahí... Glauber lo hizo asumiendo la estética del hambre y asumiendo el despelote y asumiendo el desaforo y eso lo hizo y, a partir de lo que hizo Glauber Rocha, después toda televisión 
brasileña pasó a hacer parecido a lo que Glauber Rocha hizo, porque se atrevió a hacer algo brasileño. En cambio, ahora no nos atrevemos sino que copiamos a lo que hacen en Miami. Entonces ahora todos los presentados son lo mismo, todo. Creo que nos falta pensar desde lo local, trabajar desde lo local y desde ahí construir una cosa distinta pero cercana.

\section{¿Televisiones comunitarias en Brasil serian un camino?}

Pues es que Brasil es tan grande que todo es un camino. Me parece que Brasil, más que las televisiones comunitarias que pueden funcionar, creo que van bien, lo que funciona en Brasil muy bien son los puntos de encuentro digital (Ministerio Cultura). Creo que por ahí Brasil está trabajando bastante bien. Un encuentro proporcionado por Youtube, por Facebook, por Twiter, por redes, por ahí, hay una juventud deseosa de participar. Mientras que las televisiones comunitarias, es una alternativa, pero por ahora cometen el mismo error que cometen las televisoras grandes, que es como que la televisión de Brasil quiere parecerse a Globo, Globo quiere parecerse a Fox, entonces las televisiones comunitarias quieren parecerse a Globo, entonces todo es imitación, imitación, imitación. No hay construcción de formatos y de estéticas propias. La internet se permite eso porque a la gente no le da pena ser como es, entonces en internet la gente ya es más como es.

\section{Liana habla del "Projeto Plural", coordenado por la Prof. Dra. Cremilda. ¿Quales los cambios necesarios para formar comunicadores?}

Yo creo que los cambios están indicados. Son como cuatro, digamos así, básicamente.

1. Creo que el periodista tiene que demostrar que es necesario en la sociedad. Hoy pueden desaparecer todos los periodistas del mundo y no pasa nada. Mi mamá puede hacer periodismo, mi papá puede hacer periodismo, mi hermano puede hacer periodismo. Nosotros no estamos haciendo diferencia, no estamos demostrando que somos necesarios para el mundo. Y no estamos demostrando porque o somos vendidos a los gobiernos y a las empresas; o somos amarillistas, sensacionalistas, morbosos; o estamos pasando twitters de presidentes, de los gobiernos y de los políticos y ese tipo de cosa. No estamos sirviendo a la sociedad. Entonces hay que demostrar que sí hacemos diferencia para el mundo, cumplir el mandato que dice que sin periodismo no hay democracia; por ahora, el periodismo legitima la ceocracia o la capitalcracia... no la ciudadaníacracia.

2. Tenemos que formar periodistas transmediales, que sean capaces de narrar en diversas plataformas. El problema es que la mayoría de la formación de periodistas se hace sobre el periodismo escrito. No se enseña ni periodismo televisivo, ni siquiera radiofonico, nada! 
Entonces, hoy que estamos en la convergencia, tendríamos que entrar a las clases de periodismo y decir "todas las pantallas son posibles". Usted es un periodista para todos los medios; tienes que ver si esa historia se cuenta mejor en radio, o mejor en televisión, o mejor en internet, o mejor escrita, qué ponemos de escrito, qué ponemos en foto, entonces toca formar en medios y convergencias mediales para que pueda funcionar. $Y$ enseñar que cada pantalla narra distinto, y que cada pantalla interactúan distinto.

3. Y tercero, hay que cambiar las agendas de información, las agendas de información del siglo XX (Política, economía, nación, justicia...) ya no sirve, ¡el mundo cambió! Hoy todo tiene que ver con todo. Por ejemplo, la agenda ecológica medioambiental tiene que ver con economía, con justicia, con juventud, con sociedad, con deporte, con cultura... la minería tiene que ver con todo... las agendas cambiaron y las agendas que interesan a la ciudadanía son otras. Le interesa medioambiente, le interesa espectáculo, le interesa minería, le interesa sexualidades. Entonces, cambiar las agendas.

4. Y, por último, yo creo que hay que experimentar los formatos periodísticos. En eso nos vamos a diferenciar. Yo siempre tengo la teoría de que uno, en lugar de decirte a vos "mira, ve a la realidad y me trae una crónica al medio", es "ve a la realidad y me traes una historia, en el formato que tú la encuentres". Que los formatos los dé la realidad y no que tu le impongas el formato a la realidad. Entonces, eso es difícil porque implica que el periodista tiene que estudiar mucho, tiene que formar su cabeza de manera narrativa y expresiva.

El profesor Jesús Martín Barbero dice una fórmula que a mí me encanta mucho: primero, el buen periodista, dice, tiene que pensar con la propia cabeza. Y eso, tú que ya tienes más edad como nosotros, tú te das cuenta que antes lo hacíamos. Antes veíamos arte, veíamos pintura, veíamos historia, veíamos antropología. El comunicador ahora no ve nada de eso, no le interesa el mundo. Segundo, el buen periodista debe tener qué decir. Y para tener qué decir hay que investigar. Si no se investiga...(habla como ejemplo de Vargas Llosa que se fue a Africa a vivir alla para escribir un livro ...) toca ir a investigar para poder escribir, pero el periodista hoy no investiga. La pasa en internet, la pasa en google, la pasa hablando con el ministro (no va a la calle, no escucha a la gente) y va con los políticos. Y tercero, ganarse la escucha, o sea, narrar bien. Contar bien la historia. Escuchar bien para poder contar bien la historia. Escribirla bien, hacer bien las imágenes, funcionar adecuadamente para el tipo de situación. Entonces yo creo que eso es lo que hay que hacer. 
En Brasil hay campaña pela exigencia do diploma para atuar como periodista- ¿qué te parece?

Eso va en contra del derecho humano de informar. Uno tiene que demostrar que uno es capaz para hacerlo bien. No porque tiene un título. Si es un derecho humano, no hay por qué limitar eso. Si somos tan buenos, si somos mejores que los demás, ¿por qué requerimos un diploma que el diga?

(agradecimientos, despedida). 
APÊNDICE C - JAIME TENORIO - Coordenador (diretor) Señal Colombia

Primeira parte gravado Dia 18/11/2015

Politólogo de la Universidad de Los Andes (Bogotá), Máster en Gestión Cultural del Instituto Universitario Ortega y Gasset (Madrid) y Productor de la Escuela Internacional de Cine y Televisión de San Antonio de los Baños en Cuba. Se ha desempeñado como Jefe de la Cátedra de Producción de la Escuela Internacional de Cine y Televisión, asesor en la Dirección de Cinematografía del Ministerio de Cultura de Colombia, coordinador de varias muestras audiovisuales en Colombia, consultor de contenidos multiplataforma para el canal de televisión de Telesur con sede en Venezuela, y asesor para el Ministerio de Tecnologías de la Información y las Comunicaciones en el eje transmedia de Colombia 3.0.

\section{¿Usted está aquí desde cuándo?}

Jaime: Yo estoy desde diciembre, 30 del 2013. Ya voy, en diciembre voy a completar dos años.

\section{¿Cuándo llegaste acá ya existía un trabajo, desde 2004, cuándo fue creada la Señal, pero con todos los cambios, tu venías de la televisión?}

Yo venía de haber trabajado para el Ministerio de Cultura y para el Distrito de Bogotá, con la parte de cultura. Estudié cine y televisión en San Antonio de los Baños, en la EICTV de Cuba, y luego, trabajé durante un buen tiempo en cultura y luego en cine. También me dediqué durante un buen tiempo a estudiar, yo creo que desde el 2010, todo el tema de convergencia de medios y transmedia. Me salí de trabajar en políticas culturales de cine y empecé a estudiar y a trabajar en la convergencia de medios, empecé a investigar transmedia y la convergencia. Porque para mí era claro que las cosas no venían bien en la industria de los contenidos audiovisuales, que el mundo estaba cambiando rápidamente. Y más en el cine, que estaba muy golpeado con la entrada de Internet. Y cuando empiezo a encontrarme con determinados proyectos convergentes, me impresionó mucho. Descubrí proyectos muy interesantes como libro digitales que también eran animaciones, con videos, fotografías... ¡Me interesó mucho! a partir de ahí empecé a hacer varios seminarios en Colombia junto con el Ministerio TIC, con el Ministerio de Cultura, que me apoyaron, traje expositores y expertos en el tema de Europa y de Estados Unidos. Y luego, esa experiencia fue la que me llevó a Venezuela, a Telesur, a dar una asesoría por un tiempo en convergencia de medios - eso a través de la Red Tal también, que me recomendaron y yo alcanzo estar un poco más de cinco meses en Telesur. Estando en Telesur, la Gerente del Sistema de Medios Públicos de Colombia me buscó, para que me presentara al cargo de Director del Canal. Yo no había estado 
propiamente en televisión, por lo que gran Paula Arenas, asesora de contenidos de la gerencia fue en gran medida mi guía.

\section{¿Ella está aquí hoy día?}

Hoy no, los miércoles ella es defensora de televidente en otro canal, que es CityTV, y los miércoles es su día de defensora de CityTV.

\section{¿Y como llegaste a Señal? ¿Fue una indicación, quién te invitó?}

Me invitaron por mi experiencia en área transmedia justamente porque supongo que necesitaban una persona con una mirada más amplia, la Gerente, Diana Celis, y Paula Arenas se interesaron en mi nombre. Paula había asistido a varios de los eventos que yo había organizado previamente de transmedia y de convergencia.

Gente innovadora que viene a complementar para mejorar... ¿Y cómo veías la Televisión cuando llegaste y que piensas hoy sobre el trabajo de la Señal para qué se construya mayor audiencia?

Mira: Yo creo que aquí hay varios temas que son complicados. Llegue con muchas expectativas, pero me di cuenta que la realidad es otra. Cuando entré a Señal Colombia, invité a Astrid para que fuera jefa de los productores delegados. Astrid venía de haber trabajado en la parte de televisión o de comunicación desde el Ministerio de Cultura, durante un buen tiempo estuvo allá. Para todos nosotros el desarrollo del canal y su crecimiento ha sido muy importante desde muchos puntos de vista. Porque se está haciendo producción de calidad, porque hay producción innovadora, pero tenemos problemas presupuestales, burocráticos y de normatividad, que también hace el trabajo más complejo. Presupuestal porque recibimos los recursos del Fondo de la Televisión, que administra la Autoridad Nacional de Televisión. El Fondo se nutre de lo que pagan los cable operadores y los canales privados y luego la ANTV reparte los recursos a los canales públicos regionales y a Señal Colombia. Sin embargo, el presupuesto solo se incremente generalmente en un 3\% correspondiente a la inflación. Pero ese incremento del 3\% para todas las necesidades del canal no es nada. Sobre todo cuando se quiere que seamos un canal convergente, multiplataforma, que trasmitamos en $\mathrm{HD}$, que tengamos más eventos deportivos... Entonces, tenemos muchas limitaciones. ¡Adelante! (llega Jerson Parra, Productor General del Canal y Jefe de los Productores Ejecutivos. Sigue.) Entonces con el dinero que nos gira la Autoridad Nacional de Televisión para producir contenidos, también tratamos de hacer esa convergencia, más desde un punto de vista de promoción, porque es más complejo hacer proyectos que sean naturalmente transmedia. Si 
queremos hacer una serie web, no podemos. Tienen que ser proyectos que sean naturalmente de televisión, y luego para la parte de promoción si usar otros medios. Por otra parte, cambiarle el chip, la mentalidad a la gente, también es muy complicado, seguimos pensando en la televisión tradicional, pero no en cómo expandir los contenidos. Los públicos son también cada vez más complicados y al ser un canal generalista, un canal público, nacional, en el que estamos obligados a abordar todas las audiencias desde $3^{\text {a }}$ edad, niños, pero afrodescendientes, LGBTI, todas las poblaciones, se vuelve más complejo. ... la televisión en la actualidad tiende a enfocarse en nichos, en diferentes nichos de mercado. Cuando tú tienes un canal generalista, es muy complicado porque hoy en día, la gente tiene la posibilidad de escoger. De hecho, Argentina, tiene canales como Acua mayor, que es un canal para la $3^{\text {a }}$ edad, o tiene Pakapaka para el público infantil, o Deportv, para los que le gustan los deportes, es una televisión más especializada. Están más enfocados, y se ajustan a las formas de consumo, donde el público ve desde donde quiere y cuando quiere la televisión. El otro tema es la juventud y los adolescentes. Nosotros si bien nos hemos fortalecido mucho en la televisión para los niños, para la infancia, nos faltan contenidos para los adolescentes, que es un público mucho más esquivo a la televisión. Es un público mucho más complicado, que quizás está más en la web, que flota más entre pantallas. El problema es que un canal generalista, la parrilla no alcanza a cubrir todos los públicos! Nuestra parrilla en la mañana y la tarde es principalmente infantil, y luego casi que pasamos a una franja de adultos. Que en esa franja de adultos tenemos otro problema como la misma ley de la televisión, que nos obliga a tener un gran porcentaje de producción nacional, un 70/30, que tiene que ver mucho con la contratación de equipo técnico y artístico nacional. Esto se entiende para los canales privados, para que no empiecen a comprar telenovelas internacionales y se desarrolle una industria nacional, de alguna manera, obligan a los privados a que hagan producción nacional y a contratar técnicos y artistas. A nosotros nos perjudica mucho porque no tenemos suficiente músculo económico para estar haciendo producciones todo el tiempo. ¿Entonces qué hacemos? Pues documentales de calidad, series documentales o contenidos infantiles. Las series patrimoniales de ficción las compramos, que suelen ser series de los 90, de los 80 . Digamos que nos va bien, pero también por eso es un público quizás mayor. En la noche tenemos el cine. Es una sumatoria de muchas complejidades.

Producir contenidos transmedia en la TV pública es complicado porque, justamente, si vas a hacer una serie convergente, evidentemente estás hablando de un público más joven que sería el potencial consumidor. Pero ese público más joven no es el público que está viendo el canal. 
Ibope, nos dice que nuestro público es mayor de 40 años. Es de todas formas un público que quiere ver contenidos alternativos. Que de hecho, si tu miras y revisas las redes sociales de Señal Colombia, agradecen continuamente por ser una alternativa a los canales privados, que se han dedicado mucho a hacer telenovelas, o series de narcotráfico, realities y mucha gente no quiere ver eso. Otro agravante que tienen los canales privados es la homogenización de la cultura. En la televisión colombiana, fue muy interesante las novelas regionalistas, que ayudaron a generar identidad, ahora cada vez que se van por esas series internacionales donde tienes un actor peruano, otro venezolano, otro mexicano, yo creo que eso paulatinamente ha cansado a la gente, el latinoamericano es diverso y tiene sus diferencias.. Entonces como abordar...la gran pregunta para nosotros es ¿Cómo atraer nuevos públicos, como enganchar nuevas audiencias? Pero para eso también necesitas presupuesto. Nosotros no tenemos comerciales, pauta comercial, sólo las autopromociones pero no tenemos la capacidad para hacer promoción por fuera del canal.

El hecho de estar en otras plataformas, creo que es algo que nos permite empezar a tratar de llegarle sobre todo a una población más joven, o niños, por supuesto dependiendo del tipo de contenidos. Por lo pronto se está pensando en una plataforma OTT, pero para ello necesitas muchos contenidos, porque sino estás renovando la gente se te va. Es como Netflix, que genera continuamente contenido nuevo.

Liana comenta sobre los contenidos en Brasil y en Colombia, las telenovelas, que la gente tiene que reconocerse en lo que ve. Que en Brasil el futbol es muy difundido en la televisión pero no otros deportes, como el billar, y que está mirando la programación de Señal durante esos días en Colombia, están las olimpíadas en la tele, que eso fortalece la consciencia nacional y es importante. ¿Es una exclusividad de ustedes, con los deportes la audiencia sube?

Sí, generalmente, con los deportes crece la audiencia, sobre todo cuando tenemos deportistas importantes con competencias internacionales. Lo que ha buscado el canal es acompañar a nuestros deportistas a todos los eventos, nacionales e internacionales, que no son, justamente lo que dices, el futbol tradicional, es buscar otro tipo de deportes. Pero ahí también se nos presentan nuevos retos y problemas. Porque nosotros hemos apostado por tener grandes competencias como por ejemplo el Tour de Francia y la Vuelta a España. Ahora, nos acaban de quitar los derechos Caracol porque ofrecen más presupuesto para pagar los derechos y nosotros no tenemos como superar esa oferta. Ahora: ¿porque Caracol se mete en eso? Justamente porque ganando colombianos y saben que generan más audiencia. Sin embargo, 
Señal Colombia siempre ha acompañado a los deportistas, desde mucho antes que se vuelvan populares o que empiecen a ganar las competencias. Los privados por el contrario solo se interesan cuando están ganando y porque el canal empieza a ganar audiencia, la verdad no es una situación justa.. En el caso de los Juegos Nacionales de alguna manera también son importante por lo que dices, somos el único canal que estamos transmitiendo muchas disciplinas deportivas, desde esgrima, billares, el tejo, muchos deportes populares. Ahora bien, el tema de deportes es complicado porque es un público intermitente que solo ve el canal cuando tienes deportes, y en cambio el público que ha sido fiel a la otra programación se le rompe sus hábitos para transmitir las competencias. Aquí se genera un problema porque es un público que se puede ir a otros canales o plataformas y luego recuperarlos cuesta trabajo. Ganas unos por un tiempo pero puedes perder a los que te han sido fiel. Claro, tenemos unas obligaciones y compromisos gubernamentales para acompañar a los juegos nacionales. Pero como te digo ese es el problema que nos plantea el tema de los deportes, de verdad que nos enorgullece acompañar a los deportistas y estar con ellos, y el público lo agradece, pero quizás sería ideal un canal de deportes. Cuando tenemos el Tour de Francia, o Vuelta a España, se incrementan las audiencias e inmediatamente pero eso va en detrimento del público seguidor de los otros programas de Señal Colombia de la parrilla habitual. Otra cosa que sucede en Colombia es que los que más han perdido audiencias, han sido los canales privados. Más que los canales públicos. Aquí el problema es que un público que se pierde, no necesariamente se distribuye entre los demás canales, es un público que se va, seguramente a Internet o que ya no vuelve a ver TV abierta.

"Eso pasa en Brasil también...la competición entre medios, mucha gente se ha ido pero siempre sigue siendo un medio importante. El caso de la televisión pública brasileña y las redes con canales regionales. $Y$ el impacto de los cambios políticos, que causan problemas sobre todo por la falta de autonomía y de independencia de la TV pública".

¡Eso te iba a comentar! (Jaime convida dois asesores para participarem da entrevista)

Astrid Castrillon (responsable por productores delegados): ¿tú conoces el marco institucional de la televisión de Colombia?

No, cuénteme por favor.

Jaime: Espérate, antes que tu hables de eso, de la independencia, por fortuna, hasta el momento, a nosotros nos han respetado. Antes de mi entrada, la directora era Marcela Benavides una persona técnica con mucho conocimiento de la TV que ayudó a poner orden en 
el canal, y los gerentes de la entidad por fortuna hasta el momento han respetado las decisiones del canal y no se ha politizado. Somos un canal que efectivamente seguimos siendo independiente y quizás se debe al bajo perfil, somos el canal cultural y no tenemos ni noticieros, ni programas de opinión, esto quizás nos permite permanecer en la penumbra, olvidados, no somos políticamente atractivos. En el momento en que empecemos a tener programas de opinión, noticieros, creo que hasta ahí llega la independencia, seguramente empezaría un desfile de políticos queriendo y exigiendo pantalla. Nosotros ahora podemos pasar los documentales que queramos, documentales críticos frente al gobierno, frente a cualquiera porque no se dan ni cuenta.

\section{¿Ellos no están preocupados con el Canal Institucional?}

Jaime: ¡Así es! Pero digamos que podría ocurrir que me cambiaran, pero por fortuna hay gente que lleva tanto tiempo en el canal, lo cual es bueno porque garantizan continuidad, por ejemplo Jerson (Parra) lleva cuatro años siendo el productor general, estaba antes de que yo llegara, o la misma Paula Arenas que lleva más tiempo.

Relata una situación de Brasil y sigue: ¿el tiempo que permanece un equipo de la televisión pública tiene relación con la continuidad en el Canal acá?

Jaime: No, aquí hay continuidad, a mí y a Jerson nos ha tocado tres cambios de gerente seguidos, en prácticamente año y medio tuvimos tres gerentes..

\section{¿Porque salieron?}

Jaime: Porque los gerentes son más cargos políticos. En el nivel técnico hay más continuidad ¿Ellos están abajo o arriba de ustedes?

Jaime: Ellos están arriba. ¡Claro!

\section{¡Ah, porque hay la RTVC! Allá están...}

Jaime: Entonces, hay un gerente de todo el Sistema de los Medios Públicos; hay una subgerente de televisión; una subgerente de radio. En RTVC administramos tres canales Señal Colombia, Señal Institucional y una franja de Canal Uno, que es privado, pero eso es temporal. Es algo loco, pero...

\section{P: ¿Es privado?}

Astrid: Es concesión, mejor dicho. Concesión a los espacios. 
Jaime: Eran cuatro programadoras, cada una tenía el 25\% de esto canal. Una se fue y le encargaron a RTVC administrar el 25\%. Para lo cual es el 25\% del horario de programación y también hay un presupuesto que da la ANTV para que se pueda programar ese $25 \%$.

¿las iglesias evangélicas no están también ahí?

Jaime: ¡Estaban! Justamente en ese 25\% lo ocupaban muchos programas de iglesias y lo que hizo ahora RTVC fue sacarlas, ¿no?

Jerson: son más periodísticas.

Jaime: Pero, digamos eso ha sido una ventaja y la ventaja también es de la continuidad. No es una continuidad como la de INRAVISION, donde había sindicatos, funcionarios, ahora creería que la continuidad ha sido para bien. La gente trabaja con las ganas, no son funcionarios públicos tradicionales.

Porque abajo la gente se queda. Se cambian los gerentes, se cambian los coordinadores... ¿Tú eres responsable por la Señal Colombia?

Jaime: Sí.

\section{La Señal Institucional es otro...}

Jaime: Sí, está aquí al frente mío. Entonces lo que iba a decir es que yo creo que nos han respetado mucho, se contrata gente que por lo menos viene del sector, profesionales más técnicos y no políticos. Y otra cosa que seguramente nos ha ayudado para protegernos son los premios que por otra parte pueden ser también una maldición. Es positivo porque son una muestra de que estamos haciendo las cosas bien y por eso no nos tocan, pero a su vez, a veces se engolosinan con los premios.

Astrid: Lo que está funcionando...

Sí, ¡la competencia de ustedes para ganar premios! Ustedes y Pakapaka son los competidores de Brasil. El equipo de Beth Carmona que hacía programas maravillosos, como "Menino Maluquinho", de Ziraldo (...), se ha dedicado mucho a programas para la infancia, en poner la diversidad en la tela...

Astrid: Ha estado como asesora del Ministerio de Cultura de Colombia, Beth ¿Beth Carmona?

Astrid: es jurada en las convocatorias 
Liana habla de encuentros...y del "Conselho Curador de EBC" que debería representar la sociedad, pero hay indicados por la presidencia. Actualmente hay reivindicaciones para que los miembros sean elegidos democráticamente y que sean representativos de los diversos grupos de la sociedad.

Astrid: ¿hacen curaduría para dar la clasificación?

Liana explica la función de ese consejo y que hay otro, Consejo Administración, representado por los ministros del gobierno. ¿Qué creen que sea necesario para que exista esa independencia y como asegurarla? ¿Y por cuanto tiempo todavía te quedas, tú sabes cuándo sales?

Jaime: Yo creo que queda mucho por hacer y, por el momento, por fortuna creo que me queda tiempo en el canal, salvo que la subgerente o el gerente me quieran cambiar, pero no han mencionado cambios. Mi vinculación con la entidad es bajo una modalidad de funcionario público que es nueva para mí. Yo antes trabajaba en el Ministerio pero no conocía esta modalidad. Soy trabajador oficial, eso quiere decir que cada seis meses me renuevan el contrato, es como si fuera un funcionario de libre nombramiento y remoción, pero realmente a mí se me renueva a cada seis meses. Tengo todos los beneficios de un funcionario público. Y la ventaja, de ser... ¿sabes que es un libre nombramiento y remoción? Están los funcionarios que es de planta, que no los puedes sacar y los de libre nombramiento si.

Astrid: son los administrativos

Que tienen estabilidad y nadie los puede sacar

Jaime: A los funcionarios de carrera nadie los puede sacar, y deben hacer concurso (administrativos). Y están los de libre nombramiento y remoción, que es la gente nombra un ministro o un directivo dentro de su equipo.

Astrid: que también puede ser proceso de selección, pero que no tiene que pasar por un concurso.

Jaime: Y en mi caso, si pasé por un concurso, pero interno y, de todas maneras, cada seis meses me pueden cambiar. Por ejemplo, el 30 de diciembre la subgerente me puede decir: que termina mi vinculación porque yo empecé en 30 de diciembre. En cambio a un funcionario público de libre nombramiento y remoción lo pueden sacar en cualquier momento. Si pasado el 30 de diciembre no me han dicho nada, quiere decir que automáticamente se renueva mi permanecia por otros seis meses. Por ahora no creo que vaya a haber cambios. 


\section{Liana pregunta para Jerson Parra (Productor General del Canal) y tú estás aquí hace} cuatro años, antes de eso donde estabas tú?

Jerson Parra: yo estaba trabajando también aquí para Señal Colombia pero a través de unos contratistas, a través de un tercero, en la casa. Aquí en el área de promociones y en el área cultural, como productor de una franja cultural.

\section{¿Y ahora también viniste por invitación o entraste por concurso?}

Jerson: La directora de este momento me llamó.

\section{¿Marcela Benavides?}

Jerson: Sí

\section{¿y usted hace la producción de...?}

Astrid (responde por Jerson): ¡General! Mira, aquí trabajamos el proceso de seguimiento a los proyectos. Nosotros hacemos una producción... aquí se terceriza toda la producción, nosotros no producimos nada en casa. Todo lo invitamos a convocatorias y las productoras independientes, las casas productoras producen. ¿Cómo hacemos para mantener la línea editorial y la ejecución de esos proyectos? Tenemos unos seguimientos y esos seguimientos funcionan en duplas de productores. Hay un productor delegado, que es el que se encarga de la línea editorial, de la parte narrativa, la parte conceptual del proyecto. Y hay otro productor ejecutivo que está haciendo el seguimiento a la parte operativa, modelo de producción, presupuestos, cronograma, inversión del recurso. Entonces, esas duplas que venimos a hacer, en la parte de líeles, Jerson y yo. Así mismo trabajamos por proyectos. Entonces yo soy la lía con los productores delegados y Gerson es productor general, que es el productor general del Canal pero está a su cargo toda la gerencia de productores ejecutivos.

Jaime comenta: Jerson es el malo y los dos somos los buenos (risas).

Astrid: Entonces, para cada proyecto que se asigna, a través de convocatoria o invitación, se hace un seguimiento desde esas dos áreas, de la parte creativa y desde la parte de producción. ¡Así! Y el equipo, los productores que yo soy jefa, los productores delegados, son cinco en este momento. $\mathrm{Y}$ con eso hacemos el seguimiento a sus proyectos.

\section{¿Y quién decide la parrilla? ¿Disculpen la distribución de la programación aquí se llama parrilla?}


Astrid: bueno, hay un área de programación, que tiene un jefe de programación. Hay un asesor de contenidos, que es Paula Arenas, está el coordinador...

Jaime: Paula es la asesora de contenidos de la Gerencia, pero realmente está más vinculada a Señal Colombia (Toca el teléfono, todos hablan más bajo...)

¿Ella es una asesora de ...?

Jaime: ella es asesora de contenidos de la gerencia.

¿ella no es un cargo político es por competencia, no?

Jaime: ¡Ella está por contrato de prestación de servicios!

\section{¿Y tú estás por contrato?}

Astrid: yo por contrato.

Jaime: funcionarios solamente somos dos personas, la persona de adquisiciones del Canal y yo. Cuando se acaba INRAVISION y se reforma esa entidad, yo creo que cometen también un error ahí, en la reformulación. Y es que ellos, por tratar de no tener más sindicatos ni problemas, hicieron una planta muy pequeña. Pero a mí me parece que es ridículo que un canal de televisión tenga solamente dos personas de planta. De hecho, Institucional tiene... ¿cinco o tres?

Jerson: son cuatro.

P: ¿los que no son funcionarios como se llaman?

Astrid: contratistas. A término fijo.

P: ¿y los que entran por concurso como se llaman?

Jaime: funcionarios de planta... ¿de carrera administrativa?

$\mathrm{P}:$ ¿Y en total cuantos trabajan?

Jerson: de planta son como 140 y en total son como unos... 400?

Jaime: de RTVC

P: ¿y sólo de Señal?

Astrid: setenta. Y de planta son dos.

¡Mira, qué diferente de Brasil! 
Jaime: pero sabes que eso en Colombia suele ocurrir... la gente, por ejemplo, que antes venía de cine se quedaba impresionada de la poca gente que trabajaba en la dirección de cinematografía en Ministerio o en Proimagenes, porque también las instituciones como la Ancine, el Incine en México son gigantescos...

\section{En Brasil es una percha de empleos.}

Jaime: aquí ellos ponen a marchar mucho los productores.

\section{Qué bueno que están hace cuatro años porque allá se cambia...}

Astrid: pero yo te voy a contar de la estructura... porque la institucionalidad general influye mucho también en la estructura del canal. Entonces nosotros hablamos de la Autoridad Nacional de Televisión que viene de lo que antes era la Comisión Nacional de Televisión, ahora tiene menos funciones pero mantiene las funciones de fortalecimiento y desarrollo de la televisión pública, control de concesionarios de televisión y promoción de la industria. En la Autoridad Nacional de Televisión si hay esos representantes que tú dices. Hay una autoridad que es elegida por la sociedad civil o propuesta por la sociedad civil; hay una autoridad propuesta por los gobernadores, que son como las municipalidades o los estados; hay una autoridad que es propuesta por las universidades...

\section{¿Quién es?}

Astrid: Beatriz Quiñones. No, Olga Castaño. Hay una autoridad delegada por el presidente y la otra...no sé quién es...

Jaime: el Ministro

Astrid: una por el Presidente de la República y hay otra por el Ministro de las Comunicaciones.

Jaime: es el Ministro TIC

Astrid: Entonces aquí los tres ministerios están separados. Entonces aquí la estructura es: Ministerio de las Tecnologías y las Comunicaciones - es el que tiene más recursos, que tiene el Fondo TIC, que es el fondo para las tecnologías de la información y las comunicaciones y que tendría que traer los recursos para todas esas propuestas transmedia que no son televisión, pero que no hay una asignación fija para los canales para ese tipo de proyectos. Está el Ministerio de Cultura que es un socio permanente, sin embargo no tiene recursos pues no tiene tantos recursos como para apoyar muchas iniciativas. Y está el Ministerio de Educación. 
Están separados. Esos tres ministerios formaron parte de toda la conformación de lo que fue el canal por un proceso que se llamó el Procem.

\section{Eso es bueno porque no hay un ministro preponderante en la decisión.}

Jaime: Sí y no. Nosotros somos entidad adscrita al Ministerio de las TIC, Ministerio de las Tecnologías de la Información y las Comunicaciones. Somos adscritos a ellos. Guardamos cierta independencia pero quien decide el cargo del gerente de aquí (RTVC) es entre el Ministro TIC y el Presidente de la República.

Astrid: ¡ahí sigo! Entonces aquí hay una junta directiva. Cuando se conformó toda la, digamos que en el 2006 hubo un proyecto, el Procem, que fue un proyecto para cultura y educación a través de los medios masivos. A partir de ahí salieron unos compromisos y esos compromisos son los que regulan, los que dan origen a crear Señal Colombia. Con las intenciones de diversidad, de movilización social, de todos los principios que tiene el canal. En eso participan estos ministerios. Entonces, puede haber imprecisiones en mi historia, puede haber muchas imprecisiones porque yo en esa época no estaba vinculada, estaba estudiando (Pregunta si Gerson estaba, tampoco). Eso fue en 1999, que es cuando se pasa a INRAVISION, Diana Días tiene más el panorama de eso. Ella estuvo en eso. Y Paula Arenas. Pero entonces aquí tenemos una junta directiva y en la junta directiva están los tres ministros. Jaime: la junta directiva de RTVC

Astrid: ellos hacen la junta directiva - Ministerio TIC (Ministerio de las Tecnologías de la Información y las Comunicaciones), está Min. Cultura y Min. Educación

\section{¿ese sería el consejo de administración?}

Jaime: sí, pero ahí hay otros dos, la junta completa estaría una persona de Canal 13, que es uno de los canales regionales, porque cuando se acaba, se liquida INRAVISIÓN, digamos que le pasan todo a Canal 13, que era un canal regional. Luego se crea RTVC pero ellos siguen, por eso Canal 13 tiene también oficinas aquí.

\section{¿Pero no tiene nada que ver con ustedes?}

Jaime: no, lo único es que sigue la gerencia aquí.

P: ¿pero no tiene poder de decisión sobre la programación?

Jaime: no. Pues, es miembro de la junta, ellos aprueban presupuestos...

\section{¿Y acompañan resultados, hacen la evaluación?}


Jaime: de los proyectos, no.

¿de la entidad, los resultados?

Jaime: RTVC tiene que mostrarle el reporte financiero. Aquí le falta uno, que es 472, Correos de Colombia. Eso también es porque es otra entidad adscrita al Ministerio TIC, ahí es otro donde el Ministro TIC es como un gran jefe de todos ellos.

Astrid: Entonces así es. El Ministerio de TICs está en la junta directiva como en la ANTV, que es la autoridad que regula toda la televisión también está. Digamos que ahí tiene una presencia más fuerte un poco como... en partes como que regula, formula, legisla y a parte también está en la junta directiva. Luego viene la Gerencia General de RTVC, que es nombrada por el Presidente y por el Ministro. Y luego vienen las divisiones por Subgerencia de Televisión, Subgerencia de Radio y Subgerencia de Soporte. Aquí en televisión está la Subgerente y de ahí dependen los dos canales, Canal Institucional y Señal Colombia. Y el porcentaje del otro canal. Y aquí está Radiónica y Radio Nacional. Esa es la estructura. Y hay las áreas de apoyo, de archivo, corporativo, financiero...

\section{¿Cuándo hacen la cobertura de un gran evento, como las Olimpiadas de Rio, tienen autonomía para planear, cómo es?}

Astrid: lo que se proponga surge del presupuesto pero, digamos, si son proyectos estratégicos de la entidad, o que la entidad considera, para los que no hay recursos entraría a hacer como gestión de recursos.

\section{¿Junto a TIC?}

Astrid: también, en las áreas que se requiera. Digamos, si es deportes hay otros aliados. Generalmente estos son más soporte como apoyo.

\section{P: ¿recursos humanos, el departamento que hace las contrataciones, es aquí?}

Astrid: oficina de la asesoría jurídica.

Jerson: (¿más lejano?) para asunto contractual, asesoría jurídica. Pero Recursos Humanos solamente en el equipo del Ministerio(?)

\section{¿y los concursos son frecuentes?}

Astrid: cuando hay una necesidad. Aquí hubo un gran concurso en el 2006 para carrera administrativa. Cualquier persona se podía inscribir, presentar... y se asignaron unos cargos en todas las entidades públicas del País. Hay personas que fueron delegadas a ministerios, a 
otras entidades...yo no tengo conocimiento si aquí llegaron personas de ese concurso para carrera administrativa. Pero en teoría tendrían que haber sido, ese fue un gran concurso en el 2006. Para administrativo y también áreas técnicas, hay personas en el Ministerio que llegaron por el concurso de la función pública.

(Liana presenta una planilla de cargos y ocupantes que sacó de internet para entender quiénes son - gente de subgerencia; de Señal Colombia identifican a Jaime Andrés Tenorio y María Teresa Osorio). Compara Colombia y Brasil, conceptos diversos de administración. ¿Acá cómo funcionan las contrataciones, tienen estabilidad?

Jerson: no, estabilidad sólo como te dijo Jaime, por seis meses.

Astrid: los que tienen carrera administrativa sí. Los que han participado de los concursos que te dije, sí.

\section{(sigue con diagramas, cargos y remuneración de la Ancine en Brasil etc)}

Astrid: hay dos consideraciones cuando uno piensa en el modelo de Brasil, que hay que tener en cuenta. Una es la cobertura, porque el área que tienen de cobertura es mucho más amplia, y tienen oficinas descentralizadas, que no están en la capital, nosotros estamos todos en la capital y la producción regional son las productoras que hacen... que ganan las convocatorias en su región. Pero no tenemos infraestructura en otros municipios, sólo en Bogotá. Eso es un tema. Y otro es el tema del canal generalista y no de actualidad en noticias. Porque un contenido de actualidad en noticias, sí, es una planta mucho más grande.

explica un poco sobre sistema brasileño.

Astrid: Allá también tercerizan una parte. Nosotros tenemos, digamos que esta es la ... que esto está un poquito desactualizado, la cobertura del canal y la estructura, aquí, tú sabes, es un canal nacional, público, educativo-cultural, que es Señal Colombia, y hay ocho canales regionales

Jerson: esos canales sí tienen informativos

Astrid: esos sí tienen un modelo generalista.

uno nacional...

Astrid: y ocho regionales

¿esos ocho regionales son mantenidos por los gobiernos de los estados?

Gerson y Astrid: sí. 
Astrid: (presenta un mapa) en esos sí pasa lo que tú dices - cuando cambia la gobernación, cambia la estructura. Inmediatamente. Y todos...la ANTV regula, financia todo a través de la Ley de Televisión. Entonces mira, aquí donde están los punticos es donde quedan las sedes de sus regionales. Entonces si ves, nuestra área es mucho más pequeña pero además tenemos una cobertura en región.

\section{¿están en todo el País?}

Astrid: sí. La cobertura es lo rojo y los puntos amarillos es donde están los otros canales, regionales. ¿Ves? Entonces, nosotros estamos en la capital, tenemos un alcance nacional y nuestro contenido es cultural y educativo. Institucional también tiene cobertura nacional. Y los regionales, digamos que tienen informativos, están dedicados y se crearon pensando en eso que el canal nacional no llega a cubrir que era lo que ocurría en el entorno, lo local y de interés público. Entonces está Caribe, Telecaribe, que está en Barranquilla; en el Archipiélago de San Andrés y Providencia, Teleislas; en el oriente está el Canal TRO - Televisión Regional de Oriente -; está Teleantioquia en toda la parte del Urabá antioqueño, de Antioquia y todo lo circundante; está Telecafé, que es en la región cafetera, que ahí son tres departamentos o municipalidades; Telepacífico, que es todo el Pacífico de Colombia; y TV Andina que tiene sede en Bogotá pero que abarca otros nueve departamentos. Esta es nuestra cobertura estatal. Esta cobertura cubre $94 \%$ del territorio. Este mapa está viejito pero hay toda esta parte de selva. Esa estructura que ustedes tienen en São Paulo, todo eso, eso lo cubren los regionales. Entonces eso no es de competencia nuestra.

\section{Vuelve a relatar aspectos de la realidad brasileña (comparan salarios mensuales, estructuras...)}

Gerson: vámonos todos para Brasil

Astrid: (comenta como son estos valores en pesos, costo de vida, infraestructura...) Bueno, entonces voy a seguir... te estaba explicando los canales regionales. Entonces, mira: está la Autoridad, está una entidad nacional pública que produce y emite radio y televisión públicas, que son RTVC, públicas que no son gobiernistas. Son del estado pero es de interés público. Y aquí está el Ministerio de Cultura, que tiene una dirección de comunicaciones que se encarga del fomento de contenidos propios y tiene incidencia sobre contenidos y políticas en televisión pública. En una época, en el origen del canal, a esta dirección le encargaban hacer la programación para Señal Colombia. Entre sus funciones estaba: "tienen que hacer programación para Señal Colombia”. En esa época, cuando todavía se diseñaban formatos allá 
y todo esto, estaban Marcela Benavides y Paula Arenas en esa dirección. Ya luego esto se reformuló y el Canal, como empezó a estructurarse como está ahorita dijeron "no, ellos hacen parte asesora, están en el comité de programación, están en otras instancias, evalúan convocatorias, pero la programación la formulamos desde el canal, con las recomendaciones que nos hagan los ministerios. Entonces aquí hay un comité de programación que vincula un delegado de los mismos ministerios, que están en la junta directiva, pero ya más del nivel técnico. Que sepa de contenidos, que sepa de programación, que sea como un par para el coordinador o para los productores delegados o generales, que sepa de televisión. Y en ese comité digamos que se discute la programación del canal anualmente, que se va a hacer, y se plantean las ideas desde los ministerios. Cada mes nos encontramos y se presenta como le ha ido al canal, la programación del mes anterior y qué se está pensando para el mes siguiente.

¿se hace una evaluación de cómo fue y se planea el futuro, eso?

Astrid: digamos que se hace un plan general anual y luego el detalle de cada mes se va presentando de acuerdo a que ocurran estrenos, cuando se hace un cambio entonces se comentan todas esas cosas...

\section{Y la rendición de cuentas, ¿cómo es acá?}

Jerson: la subgerente es quien lo lidera pero Jaime apoya cuando sea preciso. Los gerentes y los subgerentes son los que hacen la rendición.

Astrid: y hay los informes de las entidades públicas, de los ministerios, de la presidencia de la República...

\section{Me pareció interesante porque la gente pregunta “'porque no hicieron tal cosa...?"}

Astrid: lo que se planea y lo que se hizo.

\section{¿Eso continúa?}

Gerson: sí

Astrid: Bueno, eso es en cuanto a... la parte institucional. Hay las productoras independientes o casas productoras, que son las que hacen las producciones a través de las convocatorias que hacen el canal y la busca a niveles...

\section{¿Cuantas convocatorias se hacen por año?}

Astrid: varia, dependiendo de recurso y la necesidad de parrilla. El año pasado se abrieron ocho 
Gerson: sí, en general son entre seis y ocho anuales

Astrid: convocatorias, que son invitaciones

\section{En Brasil se llaman "editais"}

Astrid: listo. Pero además el canal tiene otro modelo, que es el mercado de coproducción.

¿lo hacen con España, con varios países, no?

Astrid: con todos, está en nivel internacional. Voy a acabar la regulación y ya entramos en eso. Entonces digamos que, a nivel de sector, el sector de la televisión no está tan organizado como el del cine acá en Colombia, que tienen agremiaciones, que hacen parte...como que tienen un delegado en instancias donde pueden participar por los derechos del sector de producción como tal. Digamos que es un reto que están tratando de suplir, pues, las instancias que están trabajando producción - ver cómo se organiza el sector para entrar a discutir temas de leyes, de legislación, en bloque, como lo hacen en cine. En regulación, bueno, nosotros tenemos una fuerte protección a la infancia, hay fomento a la infancia y la adolescencia, tenemos un fomento a la diversidad, respeto por las poblaciones excluidas, las minoritarias, digamos que hay unos compromisos a ese respeto. Existen unas cotas de pantalla para sectores, como el cine colombiano, tenemos cotas de pantalla para cine colombiano, comunidades étnicas y niños. Programación para niños, programación producida por comunidades étnicas y cine colombiano. Existen unas cotas de pantalla para producción propia, producción nacional, que era de lo que estábamos hablando ahorita. Los canales privados deben emitir por lo menos un $70 \%$ del prime time con la producción nacional. Y el porcentaje en el caso de los regionales es de $50 \%$ en esa franja, que sea nacional. Con la entrada del TLC, del tratado de libre comercio con Estados Unidos, hubo una disminución de esas cotas en los fines de semana. Pero digamos que...

\section{Eso ha dicho Diana.}

Astrid: los tratados.

\section{¿Es que la influencia de Estados Unidos todavía es muy grande en Colombia, no?}

Astrid: ¡Claro! Que digamos que si el sector estuviera organizado y tuviera ese tipo de demandas podríamos entrar a pelear más en bloque ese tipo de medidas.

\section{Sí, Latinoamérica tiene una producción tenemos que fortalecerla.}


Jaime: ¡Claro! Bueno, cuanto a los canales, hay dos canales privados nacionales de televisión abierta, que son Caracol y RCN, que digamos que se reparten la torta publicitaria. Que ellos sí pautan, sí cobran, es comercial.

¿Cuál es el que tiene la...el que domina acá, Caracol?

Gerson: lo que pasa es que el sector, actualmente sí es Caracol, pero...

En Brasil es Globo, hay un canal de la Iglesia Universal (Record), que creo que está aquí también...

Jaime: aquí hay temporadas, lo que dice Jerson. En ese momento está predominando Caracol pero...

\section{Ellos son grandes...}

Astrid: y son grandes como emporios de la comunicación, que tienen filiales en radio, en prensa, en...

¿y El Tiempo?

Jaime: lo que pasa es que muchas se han dividido, los medios, por ejemplo: Caracol Radio y Caracol Televisión son aparte, ya son dueños diferentes. En un momento fueron los mismos pero hoy en día son medios diferentes. En el caso de El Tiempo, lo vendieron a prisa, si mal creo a un grupo español que tiene mayor número de acciones, creo yo. Antes era la familia del presidente, la familia Santos, y ya no. Y ahora...

Astrid: no sé

¿Cuál es el diario más fuerte de aquí?

Astrid: El Tiempo

He leído una columna en El Tiempo de Omar Rincón ayer sobre las cable operadoras...creo que lo que pasa es eso mismo, que ha escrito...

Astrid: El Tiempo es el más leído pero está ligado a todo el tema que fue de la familia presidencial entonces está un poco como no objetivo, como muy oficialista. Aquí hay un alternativo que es El Espectador, que sale los domingos ahora, únicamente. Y El Tiempo es que, digamos que en regiones tiene otros nombres...

\section{¿uno que sea crítico, en contra del gobierno no existe?}

Astrid: anti gobierno, de frente no. 


\section{En Venezuela existe...}

Jerson: ese socialista... ¿La Voz?

Astrid: La Voz pero es muy alternativo. Bueno, entonces hay un canal público de televisión abierta que es nacional, educativo, cultural, subsidiado, no puede pautar y tiene un régimen militar(?), que somos nosotros (risas).

\section{¿tú tienes una copia de eso para mí?}

Jaime: te pasamos (por favor, se puede, me lo pasa?)

Astrid: yo te paso, es que esta es...del Ministerio. Yo pido autorización para dártela.

Jaime: pero te damos igual la información

Astrid: sí porque como también te vas a ver con ellos, esto fue una presentación que hicimos en alguna reunión bilateral

Jaime: pero te damos toda la información, digamos que eso se los hemos pasado para mostrarles a... ¿quiénes fue? A México y yo no sé quién más...

Astrid: Continuando, un canal público nacional abierto de contenidos institucionales de entidades públicas, o sea, realmente la naturaleza del Institucional es que todas las entidades que le prestan un servicio al ciudadano puedan mostrar que prestan ese servicio ahí, en el Canal. Es un canal de interés público donde las entidades que le prestan servicio a la ciudadanía pueden presentar sus programas para que la gente se entere que están ahí para servirlos. Ese es Institucional porque es de entidades públicas que le prestan un servicio a la ciudadanía. Hay otros canales regionales públicos que tienen cobertura local en sus regiones. Y existen canales universitarios, religiosos, comunitarios - hay una gran treta en canales comunitarios -, indígenas, digamos que aquí estamos... otros canales.

¿eso en el cable, no?

Astrid: no, hay unos en televisión abierta pero local y el resto son cables. Bueno, esto ya son análisis que se hizo como de...en qué es buena la televisión. Que ha sido tradicionalmente buena en series documentales, en formatos atractivos para narrativas antropológicas. Digamos que aquí se habla de una financiación suficiente...

\section{sí, estoy de acuerdo, con lo que miro siempre... ¿financiación es suficiente?}

Astrid: eh...no, pues digamos que es poca, pero ya ahorita con la Autoridad Nacional de Televisión... Y hay unas, como retos, que son: falta de continuidad en las políticas; amenaza 
al Institucional; en todo este tema de lo regional se siente mucho con el cambio de gobierno, no hay tanta continuidad en los proyectos.

\section{Los regionales... ¿pero a ustedes no, no les cambia la programación?}

Astrid: se procura, se blinda un poco para que no, se blinda...

¿si tu sales puede cambiar todo, no?

Jaime: ¡no!

\section{Porque a la gente le gusta mucho lo que tienen.}

Jaime: mira, lo que digo es: depende, sí es un tema que depende del gerente...digamos que podría ocurrir, es lo que te digo, hasta el momento, los tres que han pasado han respetado...

\section{Su dirección y su autonomía.}

Jaime: pero...podría pasar, que alguien llegue y quiera cambiarlo todo.

Astrid: bueno, entonces, Señal Colombia trabaja con siete compromisos

Jaime: ¡Ah, eso es importantísimo! que eso es como nuestro manifiesto y es:

1. Desde lo cultural, debe ser un espejo de sus audiencias. Entonces el Canal debe reflejar la identidad nacional desde todos los aspectos de la diversidad, tales como la diversidad étnica, cultural, social y de género;

2. Desde lo educativo, debe ser un recurso pedagógico. El Canal presenta contenidos no formales que facilitan y promueven conocimiento.

3. Desde lo público, debe ser una herramienta útil en la construcción de ciudadanía. Es un referente para el trabajo y la divulgación de valores culturales y democráticos.

4. Desde lo audiovisual, debe ser una experiencia cultural en sí misma. Sus contenidos tocan e impactan la vida de sus audiencias mediante la creatividad, innovación, entretenimiento, movilización y experimentación.

5. Desde lo local/global, el Canal debe ser una ventana para conocer el mundo y sus culturas. Entonces en ese escenario deben circular relatos locales con potencia universal y relatos universales que tienen una significancia a nivel local.

6. Desde lo administrativo, debe gerenciar los recursos públicos con eficiencia y transparencia.

7. Y desde lo tecnológico, debe facilitar la circulación de sus contenidos en los medios disponibles. La oferta de servicios y contenidos del Canal debe crecer y expandirse de 
acuerdo con las posibilidades tecnológicas y con las necesidades de los contenidos y las audiencias.

Digamos que esos son los 7 compromisos que nos dirigen. Cada vez que hacemos algo, pensamos ¿sí estamos respondiendo a alguno de esos compromisos? ¿Sí? ¿No? Y si no, no deberíamos estar haciendo eso.

Jaime tiene un octavo, que es ¿Cómo trabajar con la convergencia de las telas, como entender esto y cómo hacer para captar la audiencia? Y también, creo que tiene un otro: ¿Cómo cambiar de una televisión para todos para una televisión que atienda a cada segmento diferente? ¿Yo he captado bien?

Jaime: sí, así es.

Astrid: ¿Cómo trabaja el Canal? El origen de los contenidos, es que no hay producción interna, la casa no hace producción. ¿Entonces cómo hacemos? Adquirimos licencias, que es compra de contenidos; tercerizamos y es: abrimos convocatorias para que los productores independientes, las casas productoras del sector audiovisual del País, produzcan esos contenidos para nosotros.

¿ustedes tienen una idea de determinado tema que quieren? (Pregunta como son las reglas para participar).

Astrid: exacto, presentar un proceso de convocatoria

¿y ustedes tienen el planeamiento de todo lo que va a ser necesario?

Astrid: exacto, hay modalidades. Hay veces que el formato está muy desarrollado, y es: programa de cocina presentado por una niña. Los productores lo que tienen que hacer es conseguir la niña, las recetas ... Pero el formato ya está hecho. Convocatoria tema libre, y eso: lo que se les ocurra en el ámbito de lo cultural, lo educativo ... Con la cantidad de capítulos establecidos, con los recursos. Entonces hay variedades, hay cosas con formato ya que sale en la invitación o hay proyectos para que nos propongan el formato con una temática. Entonces queremos hablar sobre inventos en Colombia, inventores en Colombia. Entonces se saca la invitación, se hace un mapa temático que podría tener la invitación como para ilustrar a quien se quiera participar, a quien se quiera presentar y el desarrollo lo presentan ellos, determinan los formatos, los modelos...

¿no tienen nada de programación en vivo?

Astrid: ¿En directo? No. Las transmisiones y los magazines. 
Jaime: como nosotros no tenemos...

\section{de entrevistas así...}

Jaime: digamos que procuramos no tener tanto. Nosotros no hacemos lo que llamamos telesofá que viene a ser una producción que te puede salir más económica, pero se vuelve también muy coyuntural. Y nosotros tratamos de que nuestras producciones sean perdurables en el tiempo. Los documentales que pasamos este año y en el otro año los volvemos a pasar y el otro año lo volvemos a pasar. Hay mucha repetición de acuerdo a los ejes temáticos de programación, como por ejemplo el mes de la mujer; el mes de rompiendo fronteras; el mes de...no sé, los inventos. De alguna manera tratamos de armar la programación de acuerdo a esos ejes temáticos. Entonces, por eso, un documental sobre Totó, la Momposina, que es una de nuestras principales cantantes, cabe dentro de diferentes ciclos de programación, de acuerdo al enfoque que demos. Y además está bien porque la gente, no alcanza a ver el material cuando lo emitimos. No es que lo repitamos inmediatamente, sino durante los cilcos

\section{¿hay una reprise en otro horario?}

Jaime: no, y a veces puede ser en cuatro meses o al otro año, no es que sea en el mismo día o en la misma semana.

\section{¿y no es difícil de mantener una parrilla con cambios? Porque es complicado tener que} pensarla a cada día (cuenta de su experiencia en TV Brasil - programas fijos y cambiables)

Jaime: digamos que aquí es...

\section{¡es que es muy complicado!}

Jaime: no, y sabes que es lo que pasa, lo que hemos tratado de hacer por eso es más de ubicar unas franjas.. Teníamos un programa que veremos si volvemos a rescatar, "En Órbita". "En Órbita" era un programa de actualidad cultural, que estaba en radio, en web, en televisión. Lo que pasa tenía un presupuesto muy costoso, aquí es importante tener en cuenta que si haces producción web no es barato porque tú tienes que estar continuamente produciendo contenidos. Lo que hemos intentado hacer es que la gente empiece a identificar franjas. Como por ejemplo en la mañana se sabe y en la tarde, que son contenidos infantiles. A las ocho de la noche la gente empieza a saber que que viene el espacio para los documentales. O, a las siete de la noche las "Series para Recordar", que son estas series de los 80, colombianas, o 90. Entonces, que sepan: a las siete me voy a encontrar con series para recordar, patrimoniales. A las ocho, con documentales para pensar, que te ayudan a reflexionar sobre el mundo, te 
ofrecen diferentes miradas sobre un tema determinado. $\mathrm{O}$ a las diez de la noche, en cine, o diez y cuarto, "en cine nos vemos". Lo que pretendemos es que la gente ubique y genere recordación con las franjas horarias.

¿seriado no sería un camino, tienen algún programa que continúa? Es que Globo lo hace mucho, con base en la literatura...

Astrid: ¡en ficción! Lo que estamos haciendo para esos seriados es las series patrimoniales, que son las series para recordar, que son estas series de los $80 \ldots$

Jaime: como si fuera "Xica da Silva"

Astrid: adquisiciones.

Jaime: compradas

Astrid: Y ahí va. Y ahora estamos fortaleciendo mucho una franja de series de ficción a las nueve de la noche

¿y eso son producciones independientes?

Astrid: son adquisiciones, nosotros no las producimos.

P: ¿y no hacen convocatorias para eso?

Astrid: es muy costoso

Jaime: pues, no nos da el dinero.

Astrid: el presupuesto no... y lo que estamos haciendo es que son series latinoamericanas de México, chilenas...

Jaime: ...chilena; Presentes, argentina, de Encuentro...

Astrid: digamos que eso es una...y eso está funcionando muy bien.

Jaime: tratamos justamente de que, persiguiendo nuestro objetivo de comprarle a nuestros canales hermanos, públicos, ya que nosotros no producimos...

Astrid: pero además porque son relatos más cercanos a nosotros

Jaime: sí, realidades latinoamericanas que, de alguna manera, se asemejan más a las nuestras.

el problema de Brasil es el portugués, ¿no? Pues hay que hacer una versión...

Jaime: aunque, ¡no creas! De todas maneras ahora en Latinoamérica... Nosotros pasamos en Señal..El reemplazante, que es chilena, y claro, digamos que, en mi caso, yo entiendo el 
acento porque al estudiar en la Escuela de Cine de San Antonio, aprendí a reconocer los acentos latinos y a entenderlos ...

Es difícil para todos, ¿no?

Jaime: y sobre todo, digamos que si es un acento de barrios populares, en El reemplazante tiene muchos modismos y cosas muy chilenas que la gente no necesariamente entiende.

Astrid: y hicimos una estrategia web, que es un glosario.

\section{Muchas veces a los portugueses de Portugal no los entendemos}

Astrid: pero funcionó una estrategia en redes muy interesante. Como se dice novio...

"noivo"

Astrid: ...en México, en Chile, en Colombia. Entonces, novio, pololo...

Ah, en Brasil es noivo. ¿El que se va a casar con la chica?

Jaime: antes de eso.

Astrid: un glosario, para que entendieran el chileno un poco más.

Diana me ha dicho que acá, cuando empezaron el Canal, hicieron un manual de la programación, un manual de conducta para la televisión. ¿Todavía hay eso?

Astrid: sí, manual general, a cada año se actualiza, de acuerdo a lo que serán los proyectos.

¿y el retorno de la sociedad, qué es lo que más encanta a la gente? ¿A los adultos, por ejemplo, son las series y esas cosas de la memoria?

Astrid: hay audiencias para cada cosa. Entonces nos pueden escribir muy bien para un ciclo de cine específico, o para unos documentales específicos, en el tema de la paz, pero digamos que, o en las series para recordar... Y son amores y odios. Pues como son series de antaño, los jóvenes dicen: "están presentando viejeras”; los que estuvieron en esa época dicen: "qué bueno que vuelvan a pasar esas series, con las que crecimos", pues digamos que hay comentarios...

Mira, ustedes hicieron una cosa que fue muy hermosa, yo lo compartí en Facebook y fue un suceso, que era sobre la paz en que hablaba Mojica y otros...

Astrid: eran mensajes de campaña

¿cómo es? 
Jaime: esa es nuestra manera, en ese momento era la campaña por la paz, pues justamente... ¿eso fue producido en Colombia, ustedes lo encomendaron?

Jaime: no, esa es nuestra, esa sí es hecha por nuestro equipo de autopromociones.

Astrid: es campaña

Jaime: campaña promocional

¿fue hecha aquí?

Jaime y Astrid: ¡sí!

¡es maravillosa!

Jaime: porque digamos que lo único que nosotros sí producimos directamente, in house, son nuestras autopromociones y, como esa era una campaña realmente más corta, no son programas así producidos. Entonces es nuestra manera, digamos aquí hubo un año que era el mes de la energía, yo todavía no estaba, y autopromociones a lo largo de un año e hicimos la campaña sobre la energía. Nuestra intención el otro año es volver a reforzar el tema de la paz por lo que va a estar...y pos-conflicto porque todos esperamos que se firme la paz. Entonces digamos que eso sí.

¿van a firmar con las FARC, no?

Astrid: 23 de marzo

\section{yo pensé que era en noviembre}

Jaime. No, 23 de marzo seria la firma.

¡Mira que tengo una gana de conocer mas de las FARC! Cuando estuve en Santa Marta, hace cuatro años, fui hasta la Sierra Nevada...

Astrid: aquí hay unas particularidades por las personas que han vivido, pues que han sido víctimas del conflicto, porque siguen con unos pensamientos políticos, sí, muy definidas pero por el camino empiezan a atacar la misma sociedad que dicen defender. Entonces...

Ese "Las Niñas de la Guerra", de Hierro, es una "serie" maravillosa ¿no?

Astrid: entonces, en el tema de la programación, lo que procuramos hacer es, más que esos seriados en tira, tenemos dos franjas que son esos seriados en tira que nos dan, lo que te dice Jaime, manejamos franjas. De las seis de la mañana a las doce del medio día tenemos TV infantil, con una especificidad, para pre-escolares; para teens; para niños-niños, o sea que se 
subdivide la franja infantil. Esa parilla después te la podemos enviar junto con la documentación. Luego viene una programación que hace el enganche familiar a la hora del almuerzo; luego vuelve otra vez para niños más grandes; y a partir de las siete de la noche empieza la franja para más adultos que tiene documental, seriados de ficción hasta enganchar en la noche con el cine. Que la apuesta es...

\section{¿Y "Cuentos de Viejos"?}

Astrid: Cuentos de Viejos. Esa es una coproducción.

\section{¿pero es una idea de ustedes?}

Astrid: es una idea de Hierro (productora)

Astrid: lo que pasa es que... una de las maneras de hacer que lleguen pequeños contenidos son las convocatorias que sacamos, a invitar. Y hay otro modelo que es un modelo en el que el canal se estableció como pionero - en televisión, porque es un modelo muy del cine - que es el mercado de coproducción. Y, cada año, invitamos a los productores a que nos presenten proyectos que tengan en un estado avanzado y que nos digan ellos más o menos: "este es nuestro proyecto, en este estado está y necesitamos tantos recursos para finalizar”. Y ahí es una coproducción. Y quedamos cada uno con un porcentaje de participación. Entonces, es una invitación abierta a proyectos que estén en un estado avanzado de desarrollo, que sean innovadores, apuestas que tengan que ver con nuestros modelos de programación. Y ahí no se les dice: "este es el objeto", no se dice: "necesitamos una serie con este tema"; sino que lo que estén produciendo lo cuentan y aquí el canal hace el proceso de selección donde determinan...

¿los recursos, los determinan diciendo "tenemos tanto de plata"?

Astrid: exacto. Hay unos mínimos (y máximos). Se dice el canal no puede aportar más de $70 \%$. Entonces, cuando presentan el presupuesto el top para lo que invierta el canal es el $70 \%$.

De ahí en adelante...

\section{¿Señal entra con $70 \%$ ?}

Astrid: máximo.

¿y $\operatorname{los} 30 \% ?$

Astrid: los tiene que poner el coproductor que nos trae la idea.

¿y tienen lucro con esto?

Astrid: tienen porque el presupuesto les contempla las utilidades que requieran 
Jaime: ¿cuando, en las convocatorias?

Astrid: en coproducción

Jaime: Ah, sí.

En coproducción, por ejemplo, ustedes entran con 70\%. Digamos que cuesta 100.000 pesos...

Astrid: entonces ponemos 70.000 y ellos 30.000

¿y ellos como captan los 30.000 ?

Jaime: ellos lo aportan en especie, o porque han ganado convocatorias en otro lado, y luego las ventas, digamos, se ponen de acuerdo.

\section{¡Ah! ¿Por qué los venden para otros canales, licencian para otros?}

Jaime: sí

¿Por qué no tienen publicidad, no?

Jaime: no

¿y cuál es el interés de una productora en poner esos $30 \%$ si no va a lucrar?

Jaime: no necesariamente, ellos aspiran a ventas internacionales y a tener parte de los derechos. Pueden conseguir otros socios, coproductores en otros países o aquí mismo, y si ya tienen los equipos mejor para ellos; y luego también por ventas internacionales, se reparte proporcionalmente.

Astrid: y es más seguro

¿en las ventas internacionales se divide, $70 \%$ para ustedes y $30 \%$ para ellos?

Jaime: sí, dependiendo del porcentaje. Diría, inclusive, que cada vez son menos las coproducciones en que nosotros aportamos el 70\%. Es más (común) menos, es decir, generalmente es 60, 40, 30, depende del proyecto. ¿Por qué? Porque hay, por ejemplo, en el caso de los documentales unitarios, muchas veces son documentales que ya buscan al canal es para finalizarlos. Porque ellos ya han ganado premios, o qué sé yo, y ya tienen la financiación y lo que buscan en Señal Colombia es una exhibición ...

\section{Porque no tienen plata para aquello}

Jaime: exacto 
Liana - cita el ejemplo de Comkids: para participar es necesario tener un canal exhibidor. Y se acuerda que muchos de los programas son de productoras independientes, exhibidas en Señal Colombia

Astrid: nosotros somos exhibidores, esos coproductores, entonces, cuando tú dices ¿qué ganan?, ¿no se trata de eso?

Por ejemplo, "Las niñas de la guerra" no es una coproducción

Jaime: ahora va a ser una coproducción. Digamos que ellos hicieron unos pocos capítulos con el dinero que ganaron con un premio de Ministerio de Cultura, pero eran pocos capítulos, eran como cinco capítulos. Ahora, sí, vamos entrar nosotros como coproductores, podemos hacer en una temporada.

¿Cuántos episodios están pensando?

Astrid y Jaime: doce

en general una temporada son...

Jaime y Astrid: trece, aquí es una temporada

¿entonces van a hacer trece?

Astrid: ellos ya tienen producidos cinco y la negociación fue producir siete con el canal y participación sobre esos cinco que ya tienen para que tengamos una temporada de doce.

Hablaba con Beth Carmona sobre la posibilidad de exhibición de "Las Niñas..." en TV Brasil pero ¿sería difícil en la programación para los niños de allá?

Jaime: no, realmente no es una serie infantil.

No es una serie infantil, no

Jaime: pues, "Cuentos de Viejos" de alguna manera sí, aunque es de historia, pero de alguna manera sí, cabe, es familiar.

Es muy interesante porque es una historia muy dolorosa y está hecha en animación, entonces es una cosa que encanta, pero es...por ejemplo, ¿en qué franja ustedes lo van a poner?

Astrid: "Niñas de la Guerra" está en la noche, como son cortos, de cinco minutos, están como ¿cómo interprogramas, no?

Astrid: sí, interprogramas. 


\section{¿a ver qué más te quiero preguntar, Jaime?}

\section{Las principales dificultades encontradas en la plata y los principales entrabes}

Jaime: sí. La normativa

\section{¿la normativa cómo entrabe?}

Jaime: sí, digamos, de leyes. ¿Porque lo digo? Porque, los recursos que nos da la Autoridad Nacional de Televisión, además de ser insuficientes para realmente ser competitivos, dicen que tienen que ser para televisión.

Astrid: entonces, aquí, esta presentación que es la que tenemos ahí, tenemos la Ley 14, o sea como es toda la legislación de los acuerdos que nos obligan la programación en ciertas franjas, el tema de las cinematográficas, entonces toda esa legislación que nos regula a nosotros. El Fondo para la Televisión, todos los contenidos...

(Lee un poco del material - fondo para desarrollo de la TV) ¿y si ustedes quisieran, por ejemplo, empezar a hacer producciones propias y aumentar los empleados fijos, la planta?

Astrid: ¿para producir acá?

sí para producir acá

Astrid: no tenemos infraestructura. Eso requiere...

Jaime: de infraestructura y yo diría también que, un poco lo que responde, como responde la mayoría de canales hoy en día, es a tratar de tercerizar todo. Es porque te sale...

Astrid: los equipos, la preparación de los equipos, licencias...

Se van quedando muy "viciados" los funcionarios...

Astrid: eso pasaba en INRAVISION

Jaime: sí, entonces es un tema de negocios. Mira Discovery, tiene una línea editorial pero terceriza todo. Se vuelve también un tema de costos. Aún RCN y Caracol también están teniendo que tercerizar porque se te vuelve muy costoso hacer una producción propia in house.

Astrid: además el hecho que sean muchos productores, también te da otra visión... que sean personas, distintos productores, entonces la producción in house...

\section{Es muy difícil crear todo}


Astrid: exacto.

Lo mismo han dicho otras personas, como Omar Rincón. Pero una crítica que hizo es que participan siempre las mismas productoras, que tienen condiciones. Para las más jóvenes, que están empezando ahora es muy difícil participar de las convocatorias

Jaime: ¿pero sabes que no? En el caso de Señal Colombia es solo lo contrario, yo creo que la gente que hoy en día está produciendo... Hierro es un caso; todas esas productoras de las producciones infantiles son empresas pequeñas que empiezan primero ganando premios con el Ministerio de Cultura, que los premia en desarrollo, y hacen unos pocos capítulos, y luego vienen ya más maduros a Señal Colombia. Pero todas han empezado muy pequeñas.

Astrid: y hay varios niveles, digamos que con el mercado de coproducción hay varios niveles. Con el mercado de coproducción, digamos, lo que hemos notado es que, quienes se presentan en el mercado de coproducción, como ya requiere un músculo financiero y una experiencia, entonces son las productoras que tienen más experiencia. Tienen un musculo financiero que pueden aportar una producción. Y las que se están presentando en las convocatorias son productoras más pequeñas. ¿Qué pasa? Los que ya han recorrido ese camino, que ya han hecho convocatorias con nosotros, que han ganado convocatorias con el Ministerio, que han empezado a ser como empresas estructuradas ya dejan de presentarse a las convocatorias porque ya los recursos, de pronto, son más pequeños. Y entonces empiezan a presentarse al mercado, o sea, a hacer otro tipo de financiación. Y lo que estaba haciendo el canal es ese acompañamiento en que las pequeñas productoras empiecen a fortalecerse para que ya, luego, no se presenten a convocatorias, sino que puedan hacer otro tipo de coproducciones. Eso es lo que hemos visto, o sea, los que han crecido a lo largo de esos diez años con el canal, que empezaron a diseñar formatos con el canal, empezaron a inventarse este modelo de producción por encargo, ya son producciones que, hoy, el recurso que se entrega para un capítulo en convocatoria es menor, entonces prefieren desarrollar sus propios proyectos y decirle al canal: "tenemos este porcentaje, entre usted con este otro porcentaje". Y nos vamos. Como coproductores. Entonces digamos que esa percepción que hay, sí, evidentemente al tiempo que han ido creciendo esas productoras, en su producción, en su calidad, en sus contenidos, el canal también ha crecido y el standard se ha vuelto más alto. Porque estamos ofreciéndole cada vez más contenidos a las audiencias y no podemos echarnos para tras, hay que mejorar. Entonces el standard a nivel de las productoras es alto. Pero las condiciones de participación, sí, requieren una experiencia, no puede ser una productora que no esté constituida, que no tenga alguna experiencia en manejo de contratación pública por unos 
cupos, por unos montos específicos, pero es bastante abierta como para empezar a hacer ese camino. Digamos que sí, hay una crítica, pero también creo que el detalle no lo indagan un poco.

Sí ¿y cómo creen que se debe preparar la gente, los profesionales que salen de las facultades de comunicación, para hacer comunicación pública, para hacer televisión pública? ¿Tienen una idea sobre eso? ¿Hay acá alguna facultad que tenga esa preocupación de preparar las personas que vengan a trabajar con televisión pública?

Jaime: no particularmente, yo creo que casi que todo el mundo sabe diferenciar lo que es la televisión pública. De hecho, las grandes productoras de ficción muchas se nos acercan porque quieren producir con el canal. El problema es no tener el presupuesto, ni siquiera en el mercado de coproducción alcanzamos a tener ese presupuesto, para nosotros es realmente muy costoso. ..a mí la palabra educativo a veces no me gusta utilizarla tanto...

\section{Parece didáctica, ¿no?}

Jaime: sí, parece didáctico. Para mí, finalmente, cualquier televisión cultural, cualquier programa cultural es educativo.

\section{sí, para mí también.}

Jaime: un documental tiene un impacto en la educación

\section{Se quedó en el siglo pasado la idea de televisión educativa que es como una clase}

Astrid: aquí el educativo hay que mirarlo desde otra perspectiva

Jaime: desde otra perspectiva

Astrid: eso, educativo es algo colateral en las producciones. O sea las producciones son entretenidas, tienen un contenido y lo colateral es que aprendes algo, o que entiendes algo o que reflexionas sobre algo

Jaime: y finalmente, para mí la televisión, lo importante es que puede generar reflexión y ahora ante las nuevas generaciones que son audiovisuales, tenemos la manera de llegarles a través de las historias. Un profesor puede empezar sus clases con programas de TV. En el caso nuestro que son producciones de cinco minutos, diez minutos es muy fácil captar la atención del estudiante. Con el Ministerio de Educación estamos trabajando en unas guías didácticas a partir de los programas producidos. E inclusive tenemos un colegio en Cali en el que vimos como una profesora utilizaba la serie animada "Guillermino y Candelaria", que se 
está pasando hoy en Brasil, la profesora tomó el programa y adaptó el programa de clases de acuerdo a toda las serie". Ella enseña sobre alimentación, sobre vivienda, sobre medio ambiente y todo a partir de los contenidos del programa. Es una manera de entrarle a los estudiantes y hacer formación de públicos. Yo diría que casi todas las productoras saben qué es realmente la televisión pública y cuál es la misión. Y se nos acercan porque además en RCN y Caracol no se pueden salir de ese formato porque sino no funcionan. Nosotros tenemos mucho más libertad. De jugar, de experimentar, de hacer cosas. Y nosotros de verdad que quisiéramos meternos en ficción para, siempre hemos querido, pero el problema es (plata)...

Todavía más tú, que eres de cine, ¿no?

Jaime: sí

mira ¿y Netflix no se ha interesado por programas de ustedes?

Jaime: sí, acabamos de vender El Quijote de la Láctea, que es una coproducción nuestra; El Show de Perico", esa es producción 100\% colombiana; y...son tres, Pipo, Mi Amigo Imaginario.

\section{Es muy hermoso, yo me acuerdo}

Jaime: Esos tres se acaban de vender a Netflix, van a estar en Netflix, eso ya está asumido

Astrid: ya está

Y cuando tienen un contenido para vender, hay que negociar con la coproductora, porque como es una coproducción...

Jaime: claro, se quedan con el porcentaje

Eso es bueno porque captan...

Jaime: mira, el mercado para mí ha sido muy bueno porque ha permitido también potenciar a los productores, y a coproductores independientes. Así no se quedan viviendo solamente de los subsidios del estado, de alguna manera los obliga a ser más profesionales, a buscar en otros lados la financiación y a sobrevivir.. Y se internacionalizan. Hierro es una productora que ha venido creciendo, por ejemplo, y ellos ya, hoy en día, podrían hacer no necesariamente Yo creo que ustedes son un modelo de TV pública moderna (compara con el elefante blanco que es TV Brasil, con mucha plata que pone la sociedad, para muy poco) 
Jaime: ¿y sabes qué? Que hay otra cosa que es importante, yo creo, y eso hablando con gente de otras partes, que son coproductores nuestros, los argentinos, nos valoran mucho. Uno, el proceso de selección de la coproducción es muy serio y riguroso. Abrimos, generalmente, hacia finales de febrero y cerramos hacia mayo la recepción de propuestas. Aquí los productores hacen una evaluación muy rigurosa de cada uno de los proyectos. Hay un comité que está conformado, que está Astrid, está Paula Arenas, está el Ministro de Educación, está el Ministro de Cultura, estoy yo, está Jerson, somos como siete personas. Los productores analizan cada uno de los proyectos y nos los presentan al comité. Son los mismos productores del canal. Luego, el comité está en la potestad de decir, por ejemplo, el productor puede decir: “este proyecto no le conviene al canal, o no es pertinente", pero el comité puede decir: "no. Sí es pertinente y queremos que pase a pitch". O vice-versa

\section{Puede decir cómo mejorar, ¿no?}

Jaime: exacto

Astrid: y en este sentido, yo creo que vale la pena volver a la pregunta del tema del aprendizaje, de la responsabilidad con la gente que sale de las escuelas de comunicación ...

\section{Porque ustedes pueden hacer oficinas, ¿no? en las universidades}

Astrid: yo creo que si bien el canal no tiene como una misión explicita que diga "tienen que enseñarles a los nuevos productores", no sé qué, no sé qué, sí lo hace. Con todo este tema de empezar a presentarse a modelos de mercado que luego van a tener, pues que en el sector internacional se mueven de esa manera, y en el mismo seguimiento a los proyectos, o sea, el hecho de que trabajemos de la mano con los productores, sí es un aprendizaje, o sea, sí es una puerta a todo ese tema de capacitación de personas

Jaime: Y entonces luego viene...

\section{Imagino que ustedes haciendo oficinas dentro de las universidades puede ser una forma de pensar una producción para Señal}

Jaime: sí, eso es muy bueno, sí, que tenemos que empezar a trabajar

Astrid: y ahí digamos que misionalmente ahí el Ministerio de Cultura tiene mucho que ver. Y el Ministerio hace muchas capacitaciones para presentación de proyectos, donde lo que utilizan de modelo, como currículo, un poco es el manual general de producción del canal. Y es como se escribe y se produce en el canal. 
Jaime: entonces, lo que te iba a decir es que luego, los proyectos seleccionados pasan a pitch y lo que he escuchado es que la gente tiene una muy buena percepción del canal, nos ven serios porque hay una retroalimentación, por la formulación de las preguntas que les hacemos. Hay un respeto y se nota que los productores han estudiado el proyecto, en otros países entiendo los comités también están muy politizados o son muy de amigos. Somos muy transparentes en esa evaluación. Y luego una vez se seleccionan pasan a pitch, como decía Astrid, ese acompañamiento, también los productores son muy respetuosos de los procesos, hay de verdad un trabajo llave con eso.

Astrid: cuando uno pregunta, también, ¿Qué otros canales tienen este tipo de modelo?, de “presénteme su idea y su proyecto que está ahí, yo aporto como coproductor”, entonces, ese modelo en canales es muy raro, o sea, es un modelo muy de cine. Entonces, también cuando se presentan productores de otros países y todo eso, tratamos de preguntar: ¿en sus países hay canales que hagan este tipo de cosas? No. Hay convocatorias temáticas específicas, no sé qué. Pero, así, que sea coproducción en que yo aporto una parte, usted otra parte y hacemos mi proyecto, un poco, es un modelo que en canales no se ve mucho

¡sí, ustedes son únicos! Mira te voy a decir una cosa ahora, esto he visto en el encuentro de "La televisón es possible", que se realizó en Argentina. Me han dicho algunas personas que fue una estrategia para fortalecerse porque hay un riesgo de que todo se cambie, con el cambio de gobierno. Entonces, que fue mucho más un encuentro político como una defesa del proyecto, ¿ustedes participaron?

Jaime: participamos, de todas formas es muy importante, más allá de que fuera un momento político, la TV pública argentina son nuestros socios con quienes hemos coproducido mucho y valoramos mucho lo que ellos hacen. Estos encuentros son importantes para fortalecer relaciones.

Ustedes fueron utilizados para su fortalecimiento, ¿no?. (comentários sobre possíveis mudanças com Macri).

Jaime: si queda Macri, creo que van a cambiar. Yo creo que sí, puede ser, pero para mí y para nosotros Encuentro y Pakapaka han sido muy importantes como modelo, hacemos muchos trabajos con ellos, coproducciones. Perseguimos los mismos objetivos.

\section{Ellos son muy competentes}

Jaime:, sí, hacen producciones de calidad 
Yo tengo una admiración, ellos están en segundo lugar, primero Señal, ¿no? Por las cosas que miro allá y que exhiben acá, tenemos que reconocer que son competentes y que tienen coraje. Porque en Brasil, donde tuvimos una dictadura tan sanguinaria como la de ellos, uno no se puede meter con los militares. Es muy difícil. ¡Y tenemos un gobierno de izquierda! Que tengan coraje de hacer esa programación para los niños es impresionante, no sé si continuarán

Jaime: no, no creo. Si queda Macri...

¿van a cambiar, no? Y tengo una angustia pues es lo mismo en Brasil, que seguramente van a cambiar. Y esta es la razón de yo estar aquí

Jaime: yo creo que eso es interesante...

Astrid: tengo que retirarme porque tengo justo una cita...

\section{Muchas gracias}

Jaime: y de todas maneras...

Mantengo el canal abierto y cualquier cosa que no entienda les pregunto, por Skype Jaime: nosotros todo cuidamos...

Astrid: mucho gusto

Muchas gracias, mucho gusto. Y felicitaciones por tu compañera de trabajo

tú no las has traído, ¿ella ya estaba aquí?

Jaime: sí, yo la traje, yo me la robé del Ministerio

\section{Y los otros canales? Canal Capital?}

Jaime: interesante, yo creo que ellos empezaron a dar otra mirada de muchas cosas, porque Canal Capital para mí era un canal que no tenía nada, ellos le dieron otro enfoque pero, cuando los medios empiezan a funcionar de acuerdo a la línea política del gobernante se desvirtúa todo ¡se pierde la independiencia,! Y aquí, ya se fueron al otro lado. Porque eso qué quiere decir que ahora que hay un gobierno de izquierda, el canal responde a ese lineamiento, pero si llegara un gobierno de derecha, entonces qué pasaría?, tendrían el mismo derecho de cambiar todo, tendrían derecho a que todos los medios informativos tuviesen otro enfoque. Yo creo que ellos sí hicieron cosas buenas - y resalto a los noticieros porque dan otra mirada, 
más de izquierda -, pero pueden estar muy parcializados, como Telesur. Si son muy parcializados..no se les puede permitir

Lo mismo en Brasil, con el gobierno de PT, los gobiernos de izquierda se pierden porque quieren doctrinar a la gente y eso es malo. El gobierno de izquierda todavía no ha aprendido a manejar la comunicación pública, ¿no?

Vamos terminando...

Jaime: sí. Bueno, lo que necesites, sabes que estoy a tu disposición...

Jaime: ¿hasta cuando estás?

\section{hasta martes}

Jaime: si quieres reunirte con Paula Arenas (que te puede hablar de la historia) y con Tatiana Duplat (Señal Memoria), con Gerson (estrutctura de presupuesto, organización..) que es mi productor general, sabe todo sobre presupuesto

Sin quiero. Gracias. Te admiro, agradezco... ¿cómo piensas, si sales de aquí, que debería ser la selección, cuando salgas, la selección del dirigente de Señal?

Jaime: yo creo que lo más importante es que tiene que ser gente técnica, que conozca el medio, que venga del medio, pero también que tenga otra mirada. Tengo muchas preocupaciones con el futuro de la televisión en general, tanto con el sostenimiento como con el tipo de contenidos que se están haciendo y las diferentes formas de consumo. Creo que infortunadamente no se están tomando las medidas necesarias. En el canal tengo una muy buena relación con Paula Arenas, asesora de contenidos para la gerencia. Paula es una mujer a la que le reconozco su trayectoria y experiencia en la televisión, con ella solemos a veces tener discusiones muy interesantes, ella es el polo a tierra que jala hacia la pantalla, y yo en cambio intento jalar jalar para el lado digital. Porque mi preocupación es con los públicos, no estamos haciendo mucho por construir nuevas aundiencias, y la de este canal se está envejeciendo, salvo por el público infantil, pero una vez crece no les estamos ofreciendo nada, por tanto es una audiencia que se puede ir a otros canales o plataformas. Es muy importante que nos preocupemos por las nuevas generaciones. Debemos hacer más proyectos interactivos, más innovadores, experimentar más. Nosotros el año pasado le pedimos recursos al Ministerio TIC, a cuatro años, de la plata que es del Fondo TIC, infortunadamente el año pasado no lo aprobaron y mi intención es volverlo a pedir. El otro año empezar a hacer... 


\section{¿Hay que pedir ahora para el presupuesto del próximo año, es ahora que tiene que pedir?}

Jaime: No nos aprobaron en 2015 para el 2016. La idea es que el 2016 pienso volver a pedir para el 2017.

\section{¿En 2016 no les dieron?}

No nos dieron porque era un proyecto a cuatro años, si volvemos a pedir recursos ahora tendrá que ser a tres años. Pero tenemos que volver a insistir porque, me parece absurdo que nosotros siendo una entidad adscrita al Ministerio de las TIC no nos aporten recursos para contenidos digitales y apropiación de las nuevas tecnologías.

¿cuál sería la estrategia? porque alguna cosa que no fue aprobada este año, necesita de otra estrategia para fortalecer el pedido. Algo hay que cambiar en la estrategia, seguramente, ¿no?

Jaime: había otro ministro - es que es un tema muy político - y que la gente entienda... yo creo que hay un problema, y es que la gente todavía no entiende la televisión como una estrategia, los gobernantes no entienden la importancia de la televisión como un medio muy fuerte para llegarle a toda la gente, para enseñar, educar, entretener. Yo he tenido reuniones con el Ministerio de Educación, con el Ministerio de las TIC y ha sido muy complicado hacerles entender la importancia de los contenidos al Ministerio de Educación, nosotros podríamos ser un socio fenomenal. ¡Fenomenal! Pero a ellos les cuesta comprender. Esto es algo que valoro del gobierno de Argentina, que lo entienden como una herramienta de educación muy fuerte, política también, obviamente, pero ¡está bien!. Mi intención es tratar de empezar a hacer más gestión, de empezar a tocar más puertas; estamos tratando de reestructurar de todas maneras nuestra manera de trabajar, de los equipos - no tenemos un equipo totalmente "creativo", por decirlo así - y creativo no para hacer producción propia, pero sí para proponer. Para proponer más, para pensar. Yo creo que eso hace falta para poder hacer más gestión frente a las mismas entidades pero con proyectos en mano, de poderle decir al Ministerio de Educación: "venga, está este proyecto concreto que le puede servir en sus objetivos así como en los nuestros", debemos encontrar sinergias para que nos aporten recursos para nuestras coproducciones. Este año hicimos una coproducción con la Secretaría de Educación de Bogotá, y lo importante es que no son programas institucionales, sino que son contenidos que sirven para nuestra pantalla porque son entretenidos.

\section{De educación}


Jaime: sí, culturales. Entonces yo creo que, ahí está, entonces por eso la próxima persona yo creo que tiene que ser una persona que venga del medio, es clave. No pueden ser personas políticas, no pueden ser personas administrativas, tiene que conocer el medio, y con una visión mucho más amplia. Yo, cuando estuve liderando todo el tema de los temas transmedia y los seminarios, mi interés siempre fue juntar, hacer convergencia de verdad; hacerle entender que la persona de audiovisuales tiene que juntarse con el ingeniero o con el programador, con el de videojuegos, con el desarrollador de aplicaciones. No es necesario saberlo todo, no tengo porqué saber cómo hacer una aplicación, ni cómo hacer un videojuego, pero si saberme asesorar y hacer sinergias, tener la mente abierta de ver yo cómo hago para juntarme con otros en determinados proyectos. Eso no lo pude lograr con el Ministerio TIC durante los años que le ayudé al Ministerio TIC en Colombia 3.0 en el módulo de transmedia. Este es un evento que ellos organizan y donde logré congregar gente del diseño, de la animación, de los videojuegos, del cine. Todos iban a las conferencias que yo organizaba, pero quedaron faltando talleres y laboratorios de cocreación. Yo quería era hacer talleres o laboratorios con proyectos donde se pudieran juntar a cocrear. Cuando me vine al canal y tuve que dejar de apoyar a Colombia 3.0, prácticamente el área transmedia se acabó. Si yo me fuera de aquí, probablemente volvería a a impulsar este tipo de inciativas. Me encantaría juntar a profesionales o estudiantes de videojuegos, de aplicaciones, a cambiar la mente de las personas para ampliarles su visión.

\section{La convergencia de temas, mirada general...complejidad}

Jaime: Pues yo acabo de estar en Power to the pixel, que es para mí una de las entidades líderes en este tema en Londres, que viene tratando de incentivar proyectos convergentes. El primer día son solamente conferencias; el segundo día, me parece muy interesante, se presentan los pitch de los proyectos - no todos presentan pitch, solamente algunos de los que van al mercado. Cuando presentan el pitch se sientan en la mesa con el directores de empresas o medios relacionados, por el ejemplo el director digital del periódico The Guardian; con alguien de Netflix; con alguien de Discovery, todo depende del tipo de proyecto. También te pueden sentar con alguien de un museo, el director de la parte digital del museo... Y esas personas retroalimentan el proyecto con sus miradas y les dan orientaciones. No solamente son profesionales que saben de lo audiovisual o cinematográfico, te pueden sentar con alguien de un periódico, un museo, dependiendo de que perfil tenga su proyecto. Pero eso es muy interesante.

\section{Reunir la diversidad para encontrar la mirada...}


Jaime: Y aquí, en Latinoamérica, yo empecé en Colombia, por eso en algún momento me dediqué a viajar e ir a dar conferencias y todo... Pero en Latinoamérica hay algunos que están comenzando... Damian Kirzner, en Argentina, está tratando de hacer un evento que se llama Mediamorfosis, en Brasil está Rodrigo Terra y otros chicos que he conocido que están tratando de incentivar el tema de los transmedia. Rodrigo viene de las universidades.

Tienen muchas cosas para games, diversidad de cosas, reunir todo en comunicación porque hay una crisis de mirada...

Jaime: yo siempre trato de mirar lo que consumen mis sobrinos, que siemrpe están pegados al computador, al celular o la tableta. Su forma de consumir y acceder a los contenidos es diferente, el tipo de contenidos que les gusta es diferente. Ellos tienen otro tipo de relación. A mí me sorprende porque me aburre profundamente lo que ellos ven. A ellos lo que les entretiene son los famosos youtuber y los streamers gameers, estos últimos son chicos principalmente son europeos, españoles, que se graban jugando. Se graban jugando y van narrando mientras juegan. Mis sobrinos pueden permanecer dos, tres horas pegados viendo eso.

Yo conozco una chica de 10 años, todo el tiempo se filma, va documentando y narrando todo lo que ve, la interactividad con el celular...

Jaime: hay otra cosa que nos hace falta, ahora que lo dices, y importantísimo, los estudios de audiencias que apenas este año voy a tener. Hace cuatro años no se hacía en el canal.. y no me refiero a Ibope. Ahora más que nunca tenemos que estar revisando qué está pasando, es decir: cómo esos jóvenes están consumiendo para yo tener las medidas necesarias o por lo menos algún tipo de orientación.

\section{Yo no confío en Ibope, hay que tener otra forma}

Jaime: es verdad, requieres de estudios de audiencias cuantitativo y cualitativo y cuando yo digo el cualitativo tiene que ser principalmente un trabajo etnográfico. Etnográfico donde yo esté mirando...

\section{¿Etnográfico?}

Jaime: Etnográfico. ¡Claro! Y netnográfico. Netnográfico es el de la web, estudios de cómo la gente se comporta y consume en la web, ... Sí. Entonces, etnográfico porque en un estudio cuantitativo la gente a veces miente o mejor dicho no necesariamente refleja la realidad, salvo que sea un estudio de números para analizar tendencias comprobadas. Una persona te puede 
decir en una encuesta que compra tal tipo de jabón, pero en la realidad cuando llega al supermercado, no necesariamente compra la marca que dijo. El contexto, el momento puede hacer que compre otra marca. Por eso los estudios de comportamiento y la observación pueden ser más fiables. En una encuesta muchos diran que si ven Señal Colombia porque es el canal educativo y cultural, dirán que si ven documentales, pero en su cotidianidad, seguramente se irán por un canal que les ofrezca novelas realities, etc.

\section{No lo ven.}

Jaime: Entonces ahí cobra importancia el estudio etnográfico para estudiar los hábitos de consumo de la gente en su propio ambiente. Que pueda entrar a las casas, que pueda entrar a las cafeterías, pueda sentarse y mirar cómo, cómo la están mirando, porque entra ahí, eso es. $\mathrm{Y}$ en el netnográfico puedo observar como se comporta la gente en la web cuando consume contenidos.

\section{Otra forma de medir accesos en internet, recursos actuales.}

\section{El viernes tengo encuentro con Germán Franco.}

Jaime: Germán Franco es importante porque él era antes el Director de Comunicaciones del Ministerio de Cultura. O sea, era nuestro aliado para ...lo que te estábamos hablando que el Ministerio de Cultura ha sido muy importante, ellos tienen una oficina que es la Dirección de Comunicaciones que realmente no es de comunicaciones sino de televisión, así como hay una Dirección de Cinematografía, que se encarga del cine, la Dirección de Comunicaciones se encarga de la televisión. Germán fue Director de Comunicaciones del Ministerio de Cultura. Hoy es Ricardo Ramirez.

Jaime le dará el contacto y la localización, que es donde está Diana Díaz.

Porque Diana Díaz está en el Ministerio de la Cultura. ¿Diana Díaz colabora con la Señal?

Jaime: Sí, ella, digamos que, cómo hace parte...nosotros somos muy aliados, muy parceros.

¿quién hace parte del comité de convocatorias de la cultura, quien representa la cultura?

Jaime: Entonces, ellos hacen parte, tanto de la junta directiva, como del comité de programación. Yo me reúno, mensualmente, con una persona del Ministerio de Cultura y con una persona del Ministerio de Educación. Las convocatorias nuestras y el mercado de coproducción siempre vienen también con un representante del Ministerio de Cultura y un 
representante del Ministerio de Educación. Para las convocatorias, algunas veces viene o Sandra Téllez o Diana Díaz. Como representante para el comité de programación, sí viene Ricardo Ramírez.

P: Diana y Sandra estuvieron en Brasil apresentando un trabajo del Ministerio.... (Jaime contesta al teléfono;

Jaime le llama a Marcela Benavides para que puedan hablar una con la otra. Y luego se despiden, agradecimientos).

\section{Parte 2 (Gravação dia 23/11/2915)}

\section{Hable sobre la cifra que reciben.}

Jaime: Tuvimos incremento de 3\% al año. Espera que ya te doy la cifra exacta.

\section{Después te lo dejo para que puedas ir a tu reunión}

Jaime pregunta a alguien: ¿Este año cuanto invirtió la ANTV?

Elizabeth (del financiero): 16.385 millones. (Pesos colombianos)

Jaime: Eso es lo que nos da la ANTV. Pero espérate esto entonces, a 3 mil el dólar, sería 5 millones, 462 mil dólares. Eso es lo que nos da la Autoridad Nacional de Televisión. Haz de cuenta que a eso, cada año nos dan un incremento de $3 \%$. No es que nosotros necesitamos tanto, sino que esa es la cifra que nos dan.

¿si lo necesitan hacen un plan, no?

Jaime: con eso, sí, no. Ya lo hemos hecho y no funciona.

Elisabeth: se apegan a la cifra del ITC, que es el incremento porcentual del gobierno.

Jaime: Entonces nos aumentan en 3\%. Pero nosotros luego tenemos recursos propios de la entidad, por la Ley 14.

Elisabeth: este año nos dieron 900 millones, al comienzo del año, 927 millones de pesos colombianos.

Jaime: Eso nos entra por una ley, que es la Ley 14, que es lo que las entidades públicas tienen que pagar, es una especie de impuesto, cuando hacen comunicaciones, cuando ellos pasan promociones, tienen que pagar un impuesto y parte de eso nos entra a nosotros. De las comunicaciones de las empresas públicas. 
Jaime: públicas. Lo que ellos hagan por promoción, por publicidad, pagan un impuesto y parte de ese impuesto se viene para acá. Y mira, en ese caso son...

Elisabeth: eso sí ya es poquito, como 300 mil dólares

Jaime: Entonces a ese otro le sumas 300 mil dólares. Haz de cuenta que serían casi seis millones de dólares, casi. Luego hay veces que nos puede entrar, a la entidad le puede entrar más plata y a veces nos dan un poco más de plata a la entidad. No porque lo recibamos de la ANTV, es que la entidad, porque Señal Institucional vendió más, o qué sé yo, entonces nos dan un poco más de plata.

\section{¿Señal Institucional cuando gana más divide con ustedes?}

Jaime: nos pueden dar a veces un poco de los recursos.

¿los honorarios de todos salen de ese montante?

Jaime: No, de aquí hay parte. Todos los productores y la parte misional, técnica, se paga de ahí, de esa plata. La parte de la gente que trabaja en la web de Señal Colombia, de los contenidos de web de Señal Colombia, las autopromociones, todo eso se paga de ahí. Pero lo que es el soporte administrativo - contabilidad, la oficina jurídica - eso son gastos de funcionamiento de la entidad, de RTVC.

¿y Radiónica es otra cosa, no?

Jaime: es otra cosa.

¿y ustedes tienen una unidad de marca, como Radiónica?

Jaime: radio sí, tiene porque radio produce, obviamente, ellos no tercerizan como nosotros.

\section{¿y Señal Colombia no tiene una marca?}

Jaime: cuando hacemos una administración delegada, cuando contratamos un tercero, a veces, sí, dependiendo puede tener. Y entonces lo que hacemos es que se brandea esa marca. Se le pone la marca. Pero propia no tenemos.

\section{Porque como Radiónica tiene...}

Jaime: radio sí.

Porque tienen movimiento ¿no? Mientras no haya una oficina que tenga la participación de todas las regionales, en que cada regional entre con lo que pasó en su región y ustedes lo unifiquen...mientras eso no pasa... Tienen equipo de reporteros, ¿no? 
Jaime: no

Para eso sería necesaria más plata y más cosas... ¿ella (Elizabeth)es quien cuida de la plata?

Jaime: Sí, ella y Gerson.

¿Elizabeth, eres el brazo derecho de Gerson?

Elisabeth: sí

Una cosita más...hoy estuve con tu vecina...

Jaime: ¿de Institucional? ¿Tatiana?

No, con Tatiana voy a hablar a las cuatro. Con Alexandra Falla (Patrimonio Filmico). Pero quiero contarte algo, ya que te gusta el cine. Estuve el viernes en el Museo Nacional, caminando me metí en una saleta donde se presentaba la historia de la televisión nacional, que había varias cosas y, además, películas de Marta Trabas, que hacía el 1954 programas de arte. Yo ya estaba encantada con ella desde Brasil, lástima que se murió muy temprano. Y después me metí en otra saleta, de arquitectura. Ahí había una película hermosísima, con una narrativa perfecta de Bogotá en los años 1963, su nombre es "Rapsodia en Bogotá". ¿La conoces?

Jaime: sí

¿no es hermosa?

Jaime: es linda

Y hoy hablé con Alexandra, porque esa pelicula es de Patrimonio Fílmico, y le hablé de eso. La encontré en Youtube. Y me hizo recordar de la película de Fellini, "Roma". Y en esa película no hay necesidad de palabras. Y en la película de Bogotá es así, con música de Gershwin. Primero pensé: “es toda perfecta”. Después estuve pensando, la música debería ser de Colombia, pues la película es financiada por la Alcaldía, pero la música es hermosa, es internacional, de todas formas está linda.

Y finaliza agradeciendo

Mensagem trocada por email posteriormente

Jaime Tenorio 05/12/2016

Para Liana 


\section{Hola Liana, van las respuestas, en el correo anterior te adjunte el documento corregido con la entrevista. Van las respuestas, un abrazo}

\section{Me gustaría que comentara su partida, por que salió de Señal}

Como lo había comentado en la entrevista, en año y medio tuve tres gerentes, y estos cambios me desgastaron mucho. Cada gerente viene con un nuevo método de trabajo y suelen cambiar a las áreas administrativas como el área jurídica, planeación, etc, esto implica cambios en los procedimientos y procesos. Venía de trabajar mucho tiempo en el sector público y se me presentó la oportunidad de irme al sector privado.

y lo que usted piensa sobre el futuro de la televisión pública, las dificultades (recursos, audiencia, etc.)

Vienen tiempos muy difíciles para la televisión y en especial para la televisión pública. Claramente los contenidos no se van a acabar, por el contrario la gente consume cada vez más contenidos. Sin embargo, no veo a la televisión abierta adaptándose con la suficiente rapidez. Las audiencias son cada vez más complejas, los jóvenes están consumiendo otro tipo de contenidos y ya ni ven la televisión abierta. Están en Youtube viendo youtuber, gamers, gags, o algunas series a través de plataformas OTT como Netflix. Para competir con Netflix o HBO será necesario invertir mucho en las series que usan ahora un lenguaje más cinematográficos. No se pueden seguir haciendo solamente telenovelas, hay que diversificar, ahora hay mucha demanda de series de gran calidad. La financiación para los canales públicos será cada vez más compleja. En el caso colombiano que se financia del fondo al que aporta la TV privada y los cableo operadores, se corre el riesgo que estos aportes sean cada vez menores. Los canales privados han visto reducir el rating, y si baja el rating baja también la publicidad, y por ende el fondo de la televisión recibe menos recursos. Yo diría que por lo menos el cine, la TV y la publicidad en Colombia están en crisis, hemos dejado de escuchar a las audiencias, el colombiano no ve cine nacional salvo una que otra comedia familiar, el rating de TV ha bajado, y la publicidad es poco efectiva, porque la gente ve cada vez menos comerciales. Ese es otro universo que cambiará rápidamente, ya no seguriemos viendo esas producciones tan costosas de publicidad y con tan poco impacto. Internet y las nuevas tecnologías han impactado la forma de crear, consumir y circular los contenidos y nos está costando adaptarnos al cambio. El negocio de la música se tuvo que reinventar, y lo mismo tiene que hacer la televisión. 
Ahora estoy en una productora que ofrece servicios de cine y televisión, lo que me parece interesante es más hacia futuro, porque los dueños de la empresa, tienen otras empresas en otros sectores, y teniendo en cuenta mi interés en la convergencia creo que puede haber posibilidades interesantes. Si no logo hacer la convergencia que quiero, entonces seguramente lo seguiré buscando por otros lados. 


\section{APÊNDICE D - MARCELA BENAVIDES \\ Gravação dia 19/11/2015}

Perfil: Marcela cuenta con experiencia en televisión cultural, siendo productora ejecutiva y creativa de seriados y unitarios, así como de proyectos convergentes de carácter infantil, cultural y educativo. Como coordinadora de Señal Colombia orientó, lideró y administró estrategias de contenidos, producción, programación, financiación y distribución del canal en todas las plataformas. También diseñó e implementó el Mercado de Coproducción, estrategia internacional de cofinanciación de contenidos. Actualmente (en 2015) orienta la construcción del Plan Nacional para las Artes 2015-2020 del Ministerio de Cultura y es consultora de La Lupita Producciones para el diseño de canales públicos culturales de Perú y Chile.

\section{Preséntate, por favor}

Yo soy Marcela Benavides soy realizadora de cine y televisión, llevo 17 años trabajando en televisión pública desde distintos ángulos en primer lugar yo dirigía el Centro de Producción Audiovisual de la Universidad Nacional de este País. Ahí hacíamos producciones de documentales y seriados que tenían que ver con investigaciones académicas de la universidad, con temáticas relacionadas con ciencias humanas, medicina, ciencias políticas y esos contenidos se los presentábamos a través de convocatorias a Señal Colombia. Esto en una etapa previa al 2004, donde Señal Colombia era más un programador del Estado que un canal como ocurrió posteriormente. Lo que hacían entonces, era dividir la parrilla y entregar espacios durante un año a las universidades, a otras programadoras independientes, y a distintas instituciones del estado (salud, educación, ciencia, etc), tenía en su parrilla también las transmisiones en directo del Congreso de la República.

En el año 2004, hubo un cambio fundamental en la Televisión Pública. Señal Colombia dependía del Instituto de Radio y Televisión (INRAVISION se llamaba) toda la gente que trabajaba en el canal estaba en planta, eso significa que los equipos eran propios, la infraestructura y también la gente, se dice que había cerca de $\underline{600}$ personas en planta, contratadas a término indefinido. Venía dándose una crisis del modelo de operación y un déficit presupuestal porque no había suficientes recursos para las pensiones. El déficit pensional hizo que se liquidara esa entidad, INRAVISION desapareció. Y surgió RTVCSistema de Medios Publicos, que es la empresa que maneja en Colombia Señal Colombia. Actualmente. $\mathrm{Y}$ en ese momento decidieron liquidar a todos los empleados y dejar una planta 
muy pequeña de, más o menos, 70 personas y que la contratación para producción se hiciera a partir de terceros.

\section{¿Fueron demitidos?}

Sí. Entonces ya no había producción interna sino todo contratado externamente. En ese momento hicieron un rediseño donde Señal Colombia dejó de tener a su cargo la programación institucional y asumió exclusivamente la programación educativa-cultural. Desde ese momento surgieron dos canales además de Señal Colombia, un canal Institucional, en donde están todas las emisiones del congreso de la república y todos los contenidos de los Ministerios de Defensa, de Salud y de las demás instituciones. Fue algo muy bueno porque Señal Colombia era un canal un poco frankenstein porque había simultáneamente programación para niños y luego transmisiones del Congreso de la República, luego del Ministerio de Defensa, era todo terrible para las audiencias.

Entonces en el 2004, lo más importante que ocurrió fue que se dividieron los dos canales y se cambió el modelo de producción porque ya no habría producción interna, sería todo tercerizado. En ese momento yo estaba trabajando como asesora de Televisión en el Ministerio de Cultura. En esa nueva estructura (4:18) la junta directiva del canal estaba conformada por el Ministerio de Educación, el Ministerio de Cultura y el Ministerio de Comunicaciones. Con esos tres ministerios se hicieron una mesas de trabajo para diseñar los contenidos de lo que programaría el canal, el modelo de programación y el modelo de tercerización, de cómo se iba a contratar la gente y como se iban a hacer las convocatorias. Entonces, lo que se hizo en ese momento fue dividir salomónicamente la parrilla mitad para (Ministerio de) Educación, mitad para (Ministerio de) Cultura lo que fue un error también porque la audiencia no tenía por qué consumir los contenidos según lógicas institucionales). Por la mañana de 8 a 5 de la tarde era de Educación y de 5 de la tarde a 12 de la noche era de Cultura.

Como decía, en ese momento yo estaba en el Ministerio de Cultura y trabajé de la mano de mi jefa que era la directora de Comunicaciones, ella se llama Guiomar Acevedo. Yo estoy trabajando con ella en este momento, en el Ministerio en la dirección de artes. Guiomar había asistido a todos los talleres, ella conocíó a Beth (Carmona), conoció también el trabajo que hizo en... un compromiso con televisión de calidad.

Que no sé si conociste a Patricia Castaño y Adelaida Trujillo.

Sí en 2003, cuando estaba escribiendo el libro de la televisón TVE, en Rio de Janeiro, conoci a Patricia. Las voy a encontrar sábado. 
Entonces, Adelaida Y Patricia firmaron un acuerdo por la televisión pública de calidad y ellas empezaron a traer conferencistas de todas las partes del mundo y los canales públicos y regionales siempre participaron. Y Guiomar Acevedo, inspirada como en todas esas experiencias que se contaban desde afuera, ella lo que dijo fue: 'tenemos que hacer un diseño de TV de calidad inspirada y también con unas referencias muy claras a ese tipo de cosas". La televisión de calidad tiene participación de la audiencia, nos hizo leer una cantidad de documentación sobre la $\mathrm{BBC}$, sobre cómo debería ser todo eso, y en ese momento el canal decidió implementar la figura de productor delegado para hacerle seguimiento a la programación que se tercerizaba y empezamos la construcción de herramientas de seguimiento que fue el Manual General de Producción que tiene cuales son lineamientos para que los contratistas externos produzcan los contenidos y también empezamos a hacer el diseño de las convocatorias.

Entonces, desde el Ministerio (Cultura) se establecieron cuáles eran los mínimos para el desarrollo de la producción realizada por terceros, exigiendo que hubiera un desarrollo de investigación más profundo en donde estuvieran justificados los temas, los enfoques, los personajes, donde estuviera también planteada una consistencia entre el tratamiento audiovisual y la audiencia a la que estaba dirigido. Porque antes la gente recibía los contratos y hacía el programa como le gustaba al director y no pensando en todos estos aspectos. Se empezaron a hacer unas fichas de convocatoria, en donde cada ficha tenía cuál era el objetivo temático, cuál era el objetivo para las audiencias y que tipo de narrativas se estaban buscando. Y se empezaron a abrir esas convocatorias.

Todo este proceso desde el Ministerio (Cultura) generó una primera versión de como se hace una convocatoria, como se evalúa, quienes son los jurados que pueden evaluarla, como se producen los contenidos; y como se hace el seguimiento de esos contenidos, como se hace la evaluación. Y en esos primeros años se empezó a fraguar toda esa base conceptual. Fue un trabajo muy arduo y difícil para convencer al sector audiovisual que entrara en esas dinámicas porque no estaban acostumbrados y no querían que el canal interviniera en sus creaciones. $\mathrm{Y}$ fue un poco convencerlos de que no es un premio como cuando tú te presentas a un fondo concursable, sino que estás haciendo algo por encargo para un canal que tiene unas políticas editoriales, unas políticas para cada franja de audiencia y que tiene que ser consistente con eso. Entonces tomó muchos años la transición, fue mucha planeación, ensayo y error, además porque tuvo muchas interrupciones. Señal Colombia (RTVC) en estos 15 años ha tenido demasiados cambios en sus directivos, ha tenido ya 7 o 8 gerentes, ique es mucho! lo que resta posibilidades de continuidad y de consolidación de procesos. Y los cambios de los 
directores del canal y demás. Entonces lo que ha sobrevivido a los años un poco es la metodología, y aunque a veces la han querido tumbar porque es importante señalar que, también esa metodología, además de pensar en la televisión de calidad, rompió con un tema político y es que algunos directores anteriores contrataban con criterios de cercanía a sus amigos, contrataban gente de la vieja guardia, que no necesariamente es malo, pero en este caso mucha de esa gente llevaba haciendo televisión 30 años y no estaba interesada en aprender nuevas miradas, nuevas narrativas y entonces eso también generó como una limpieza de qué tipo de gente se presentaba y empezó a entrar gente joven, empezó a entrar gente muy joven, salida de las universidades, independiente, que estaba con sus propias ideas y, pues, eso fue muy bueno porque renovó el canal.

\section{¿Cuánto tiempo duró el proceso de construcción, del 2004 o empezaron antes?}

Empezaron unas mesas del trabajo antes del 2004, en 2004 se empezó a implementar, fueron dos años de trabajo.

En Brasil fue en el 2007. Pero fue todo muy loco, había gente de cultura, cineastas, periodistas, cada uno con una idea, era un conflicto, la Secretaria de Comunicación representaba grupo periodista y del otro lado la gente del Ministerio de Cultura de Gilberto Gil con los cineastas, una confusión. Y han llegado como 14 gerentes, cada uno con una cabeza.

Marcela: Aquí no fue muy diferente porque, lo que te digo es que el Ministerio de Educación tenía una mirada muy curricular, con la que no estábamos de acuerdo desde Cultura, entonces por eso no se pudo hacer una parrilla articulada. Y lo que hicimos fue: bueno, partamos ustedes a las 8 de la mañana hasta las 5 de la tarde -, que era una cosa también un poco loca pero no había manera de compaginar las cosas porque ellos querían que los niños aprendieran matemáticas, ciencias, lectura y que además los pudieran evaluar y que fuera un instrumento para las aulas, y desde cultura estábamos convencidos de que la televisión no debe ser eso. Y aunque claramente, sí, sirve para apoyar procesos educativos no de esta manera tan instrumental, más formación. Entonces, en esos primeros 3 o 4 años el canal se manejó con esa parrilla diferenciada hasta que en los análisis y estudios se vio que eso no funcionaba.

Las bases del canal fueron las que cambiaron el modelo fueron la tercerización, el perfil de gente que entraba a trabajar, que entró un proceso de seguimiento y aprobación de cada una de las fases de producción. Que eso antes no existía. Antes, cuando el canal producía, contrataba a quien le producía y recibian el producto final pero no había aprobación de los guiones, aprobación de los personajes, del casting de todo esto y lo que se empezó a 
implementar desde el 2004 fue que había una aprobación de cada una de las fases. Y eso, pues, fue un cambio también de mentalidad para todo el sector

Otro gran cambio fue pensar en que, también, a fuerza de que nos dieron la parrilla de las 5 de la tarde a 11 de la noche, también queríamos hacer programación para niños pero entonces los horarios no parecían convenientes y empezamos a hacer contra-programación, entonces empezamos a programar por la noche para los niños, contra el prime y nos fue mejor, fue una cosa más bien casual. ¡Y nosotros empezamos a producir contenidos muy malos! Nuestros contenidos infantiles inicialmente eran muy malos porque venía la gente con el imaginario de diseñar lo que a ellos les hubiera gustado ver cuando ellos eran niños y no con la producción que se hace con los niños de hoy. Y romper con eso también fue algo muy difícil pero se generó un movimiento importante del sector independiente que viajaba a Prix Jeunesse y al empezar a ver las cosas que se hacen en el resto del mundo, se capacitan y funcionó todo muy bien. Básicamente eso fue lo que ocurrió como que en la primera etapa del canal.

Hubo también un hito importante en el 2005 hasta el 2007, que fue la producción de dos contenidos que rompieron un poco la visión que tenían los televidentes de la televisión pública. Porque, claro, demoró siempre unos dos años en empezar a verse al aire lo que se estaba proponiendo hacer y romper con lo que se venía viendo antes que era un canal que tenía mezcladas cosas institucionales con cosas educativas-culturales y de niños, pues todo esto que te conté. Y cuando empezaron a ver una parrilla un poco más organizada y con unos contenidos diarios frescos y nuevos para jóvenes y para niños, se inició un cambio visible.

Porque es que lo que antes se hacía era que a todo el mundo le daban una serie de 52 semanas para todo el año y entonces se las repartían a 23 empresas y todo el mundo tenía una hora y así se llenaba la parrilla y no había tampoco ninguna estrategia de programación.

Fueron dos programas, tres en realidad. Uno que se llamó La sub 30 que fue un programa para jóvenes, que era programa para menores de 30. El nombre, parte de que en futbol se dice a la selección juvenil la sub 20, entonces esto se llamó así. Este era un programa diario en donde había dos presentadores muy jóvenes que viajaron por todo el país haciendo el registro de toda la movida cultural de los jóvenes rurales, indígenas, pero también de los jóvenes urbanos mostrando clips, deportes, artes, audiovisual, cultura y se empezó a dar a conocer una cantidad de cosas. Este programa se volvió referente para enseñanza en facultades de comunicación y de cine porque a los muchachos les gustaba mucho. Entonces se volvió un programa para este nicho hasta entonces desatendido.

Antes no había nada así, ya ahora hay muchas más posibilidades pues, en esa época no existía Netflix, ni nada. Entonces, fue algo que demostró que la televisión cultural podía ser 
entretenida y que con el mismo presupuesto se podían hacer cosas que podían ser interesantes para nichos, porque nunca fue masivo. El otro programa fue Culturama, que fue un programa, era un magazine cultural diario también, que tuvo ese espíritu de descentralizar. Porque Colombia, es un país muy centralista y muy regionalista a la vez, hay 9 canales regionales y esos canales solo se miran a sí mismos y lo nacional, en realidad, es muy bogotano. El gran objetivo de estos programas fue mostrar el resto del país pero desde la mirada de ellos, de traerlos y fue también una cosa novedosa en ese momento.

Y también se hizo una franja de cine, diaria, con un pequeño intro, en donde alguien que era experto, un especialista, hacía una introducción temática o, según los ciclos, hablaba de cada una de las películas, dando un contexto. Y la gente le escribía y él contestaba, y con un fuerte énfasis también en el cine Colombiano. En el cine, entendido el cine no solamente como ficción, como también documental, cortometrajes. Y fue muy interesante porque en ese momento Señal Colombia empezó un posicionamiento de ser la casa del cine nacional. Y el cine también en Colombia, paralelo a todo esto empezó a tener un crecimiento en esta época se estrenaban tres películas anuales, hoy se estrenan 17. Entonces fue también como ir de la mano mostrando todo este fenómeno, ¿no?

\section{¿hoy 17?}

Marcela: 17, sí, pues de calidades muy diversas, pues no es que todo sea bueno pero, pues se está viendo, de todas formas. Eso fue en esa etapa. Yo dejé el Ministerio en el 2007 y empecé a trabajar...

\section{¿estuviste hasta el 2007?}

Marcela: desde el 2004 hasta el 2007 en el Ministerio asesorando esta estructura, convocatorias todo eso... que es el cargo que tiene German (Franco), el que tenía, perdón, ahora es Argemiro Cortes.

\section{¿Diana (Diaz Soto) es su asesora, no?}

Marcela: sí. Entonces, en el 2007 me fui para Señal Colombia como productora delegada.

¿Productores delegados son los que se responsabilizan por coordinar los productores independientes?

Marcela: ¡Exactamente! Ahí yo trabaje junto con Diana (Diaz Soto). Diana y yo trabajamos juntas en esa época. Todos habíamos estado aquí y allá.

\section{El mismo equipo, ¿no? Y todos hablan muy bien unos de los otros}

Marcela: Sí, ella coordinaba muy bien. En esa época entonces, como productora delegada, yo tenía muy claro todo esto que era lo que se había implementado y era tratando de ponerlo en marcha, porque desde afuera lo que yo había hecho era asesorarlo, escribirlo y proponerlo 
pero no ejecutarlo. Entonces ahí, pues, teníamos a cargo cada uno más o menos unos 7 proyectos. Y era implementar todo esto. Ahí, mientras yo estuve de productora delegada, yo tuve tres jefes diferentes, como coordinadores de canal y subgerentes... Entonces cada vez que llegaba cada uno de ellos era explicarles porque se hacía todo esto. Porque les parecía que era muy enredado, y que no había necesidad, que más fácil era contratar la gente y ya no ponerse a hacer ningún tipo de seguimiento, ni tan intenso, porque para qué, en fin... Y volver a convencerlos. Porque nosotros, con los productores delegados, teníamos un equipo así súper unido y cada vez que había un cambio, así como soldados, defendiendo que no fueran a cambiar esto porque casi siempre venían con ideas de traer sus personas cercanas, cambiar...

\section{¿Todos esos nombrados políticamente, no?}

Marcela: Sí. Todavía es así. Todavía sigue siendo así. Los que llegan a los cargos de subgerente y en gerencia (RTVC) casi siempre han sido personas que vienen de cargos políticos y luego siguen trabajando en cargos diplomáticos o políticos, que en la mayoría de los casos no tienen nada que ver con los medios de televisión, ni públicos, ni privados, ni nada.

\section{Y los coordinadores también son de confianza de la gerencia?}

No necesariamente porque yo no era de la confianza de nadie. Yo me mantuve ahí porque creían que les funcionaba, porque conseguía resultados. Cuando querían hacer cosas que no correspondían a los objetivos o principios del canal, siempre estaba como (resistente)...

Fueron 7 años de lucha, entonces

Sí. Es que coordinadores del canal ha habido pocos, solamente ha habido 4 desde esa época.

\section{¿Tú fuiste la que ha quedado más tiempo, no?}

Sí. Porque antes estuvo Yolanda (?), que estuvo en la primera parte ya se jubiló, después entro yo.

\section{¿Tú saliste porque quisiste?}

Sí, yo estaba muy cansada.

Si es desgastante, yo nunca más voy a querer algo así en mi vida, yo tuve experiencia en televisión y después en la radio en Rio, en cuanto estuve con Beth Carmona. Porque Beth fue invitada por el ministro pero porque tenía un nombre técnico importante, no fue por cuestión politica... pero los otros que entraron, después de Beth fueron unas cosas más políticas. 
Este cargo, (25:37) (coordinador del canal) generalmente ha estado gente que le importa y para arriba no, entonces siempre es tratando de convencerlos, de evitar que tomen decisiones que afecten el presupuesto, este tipo de cosas.

\section{Sí, teniendo que defender siempre el canal}

Sí, así es. Y estuve un año de productora delegada y de ahí ya como Coordinadora del canal. Eso es una cosa buena, yo creo, mira cuando ponen la gente que conoce, que saben es un gran avance para la institución, ahora están todos los empleados de la EBC en Brasil en el paro se está divulgando un documento donde critican el ministro y quieren que la gente que está en la planta tenga acceso a los cargos de gerencia... ¡y es una cantidad de gente! Si ustedes tienen 70, allá mucho más...sólo en la televisión, que es mucho más que en las radios...

No, pero ya esto creció, ya no son sólo 70. Ya creció, creció. Setenta fue en el 2004 pero... (hace una pausa para hablar con Diana). Cuando cambiaron eran como que 600 y quedaron 70. Y ahora yo creo que debe ser más de 200 en la planta, pero no estoy segura.

\section{¿Solamente en Señal?}

No, con todo (RTVC). En Señal Colombia, en planta, cuando yo estaba éramos 5 personas y como 70 contratistas en el 2013. En Señal Colombia, solamente, 5 en planta y 70 contratistas.

¿Esos contratistas son...?

Productores delegados, productores ejecutivos...

¿pueden salir a cualquier momento?

Sí, pueden salir a cualquier momento, exactamente. Pero aparte de eso eran más o menos $\underline{80}$ casas productoras produciendo para el canal, para un año. Entonces, estos 70 contratistas entraban por procesos de selección y los elegía el coordinador. Y esas $\underline{80 \text { casas productoras }}$ entraban por convocatoria pública.

¿Aquí estaba en gerencia política en esa época?

No, sólo Señal Colombia,

¿Pero Señal Colombia no depende de indicación, son contratados por el coordinador?

Sí, por el coordinador, generalmente.

\section{¿Y ellos no tienen estabilidad?}

No. Los únicos que tenían estabilidad eran 5 , todos los demás eran contratados por meses o por el año y los podían renovar o no.

Por que mira, Jaime me ha dicho que tiene un contrato que a cada seis meses lo tienen que renovar. 
Es igual que yo, era igual que yo. Pero no es así. Eso es lo que se llama, no sé cómo se llamará en Brasil, contratos por libre nombramiento y remoción, son cargos de confianza, y a uno lo pueden evaluar a cada seis meses pero no es que se te van a sacar. ¿Si está bien tu trabajo, porque te van a sacar? Pues yo nunca me sentía como en riesgo, a no ser que hubiera un cambio de jefe, entonces yo decía: sí el cambio de jefe coincide con mi cambio, posiblemente quiere traer a alguien cercano. Pero, generalmente, mi cambio, mi terminación de contrato siempre coincidía con resultados de premios o cosas así, entonces venía con los premios y llegaban y decían, "no, mejor sigamos" (risas).

Por ejemplo en Brasil, en la Globo, la gente está hace muchos años, hasta 20 años, las cabezas y jefes. Y en la TV pública no, si cambia el gobierno cambia la dirección completa. Pero mira ahora la EBC tiene 8 años, porque veo que aquí todo empezó antes, la TV Nacional se ha creado en 1954 en el gobierno del general Rojas Pinilla y se quedó poco tiempo, fue creada por un hombre muy joven (Fernando Agudelo). Después en el 2004 se convirtió en la Señal Colombia y se crea una nueva dinámica del sistema de medios públicos.

En Brasil, en 2007, se creó la EBC y lo asumieron las emisoras vinculadas al gobierno federal, lo que era separado, la Radiobras, lo juntaron con la TVE Brasil (ACERP), hoy TV Brasil. La crítica que se hace en Brasil, es porque están vinculadas a la Secretaria de Comunicación del governo (SECOM), que son responsables por la imagene y por la comunicación del gobierno y junto la programación para la sociedad (TV Brasil). En Brasil fue Radiobrás y TVE Brasil independientes entre sí. Cuando es separado, es un mejor modelo, como en Colombia. Tienem el Institucional. ¿Que te parece?

$\mathrm{Si}$, de todas maneras es difícil porque en los cambios que ha habido (34:48) (pausa para buscar documentos)

Brasil me parece esta atrás de Colombia tanto en la creación, como en la producción de la TV pública. Eso en los canales privados existía, pero no en los públicos.

Pero mira que por ejemplo "Pakapaka" y "Encuentro" (Argentina) empezaron mucho después y consiguieron resultados mucho más rápidos porque había una continuidad y también una rigurosidad como en toda la parte editorial y metodológica, yo siento que ha sido muy bueno, mucho mejor que el proceso de acá. Pues aquí el proceso ha tenido que volver a empezar 3 o 4 veces porque justo cuando todo está más interiorizado por parte de los equipos nuevos, del gerente, el sector, llega alguien nuevo, y hay que volver a comenzar... Y los procesos son muy largos, los procesos estatales de contratación son muy largos. Entonces nombran un jefe de jurídica, un jefe de administrativo, generalmente, lo misional ha estado supeditado a los 
procesos de apoyo logístico, administrativo y jurídico, llegan personas que han sido expertas en contratación estatal pero para construir puentes o para hacer cosas de salud y no de televisión y entonces les parece que no se puede, que no se debe. Y también tenemos la vigilancia de la contraloría, la fiscalía, la procuraduría, los que hacen vigilancia sobre el gasto público, y ellos sí que tienen una mirada obtusa y no entienden que una animación de un minuto pueda costar mucho más que un programa de dos horas. Eso ha sido algo muy complicado porque poder explicarle a la contraloría que no se debe tener ese tipo de mirada respecto a eso, la calidad, para ellos da lo mismo una cosa que la otra. Entonces es muy difícil.

\section{¿Y eso pasa todavía?}

Todos los años la contraloría hace ese trabajo.

\section{¿Tú crees que eso haya cambiado mucho?}

No lo sé.

Jaime me ha dicho y me hablo sobre su experiencia pero yo entendí que quiere continuar, ha llegado una chica que se llama Astrid, que trabajó con Diana.

¡Ella es muy buena! Si Astrid trabajó mucho en la dirección de comunicaciónes del Ministerio de Cultrua.

Hable con ella y con Jerson que esta mas desde ese tiempo

Si él era mi productor

No hable mucho con Jerson, pero Jaime dice que no sabía todo, que él piensa mucho en la convergencia, lo que los niños de hoy están mirando

Digamos que si ha habido una relativa continuidad porque los procesos son muy largos, cuando el llego había muchas cosas que ya estaban andando y recién contratadas por dos años.(coproducciones internacionales)

¿Él ha conversado mucho contigo cuando ha comenzado? Porque tener una inmersión en el proyecto es importante.

$\mathrm{Si}$, digamos que cada persona tiene una mirada y él tiene una mirada sobre la convergencia, pero acabó el único proyecto de convergencia que había en camino acabó porque le parecía que era muy caro, pero estaba apenas madurando llevaba un año que se llamó En órbita.

Estuve mirando el portal, miraba siempre, pero de repente parece que lo cambiaron mucho, había los programas, algunas cosas ya no las encontré.

$\mathrm{Si}$, para mí a pesar de que me fui por voluntad propia fue difícil separarme del proyecto por tantos años y decidí por bienestar, también, tomar un poco de distancia, porque estar pendiente de lo que hacen o lo que no hacen no era tan buena idea, sobretodo porque duraron 
un poco de tiempo antes de que entrara Jaime y el canal estuvo en manos de los directivos que sé que sí tenían una mirada muy distinta. Luego desde que él está, que ya van a ser 2 años, él ya ha tenido 3 jefes diferentes.

\section{Jaime me ha hablado de Paula, ¿quien es?}

Paula (Arenas) es asesora de contenidos de RTVC

\section{Del gerente?}

De todo el canal, ella es muy buena y ella también estuvo en el comienzo, ella estuvo en el Ministerio de Cultura. El cargo que yo tuve era de ella en el Ministerio, ella comenzó con Omar Rincón en una investigación.

Lo que se hizo al principio, (yo te voy a pasar esta presentación,) se llamaba INRAVISION desde el 1964 hasta el 2004; RTVC del 2004 a la actualidad. Aquí están los distintos cambios que tuvo el canal educativo-cultural, se llamaba primero Canal 11; Canal 3; en el 95, Señal Colombia; de 2001 al 2005 La Señal. (Muy buena la presentación)

\section{¿Y en la pantalla cambiaba también el canal, el nombre del canal?}

$\mathrm{Si}$, le cambiaban todo, el logo todo. Y también había una programadora estatal que se llamaba AUDIOVISUALES que también coincidió en el 2004 (se liquido) cuando se hizo la liquidación de INRAVISION y el surgimiento del Canal Institucional. Y bueno, la otra cuestión es que la televisión pública se financia con los fondos de la Comisión Nacional de Televisión, que ahora se llama Autoridad Nacional de Televisión. Esos fondos vienen de los operadores de cable y de la venta publicitária de los canales privados. Ese modelo hace que tenga asegurado un presupuesto del 1\% o menos dependiendo. En algún momento fue 1\%, ahora ya no sé, tendría que confirmarlo. ( $1 \%$ de la venta publicitária?) http://www.antv.gov.co/index.php/la-antv/fomento-para-el-desarrollo-de-la-television-y-loscontenidoshttp://www.antv.gov.co/index.php/la-antv/fomento-para-el-desarrollo-de-latelevision-y-los-contenidos

http://www.antv.gov.co/index.php/component/jdownloads/send/46-fontv/665-documentoregulatorio-que-soporta-la-res-0292-de-2013?option=com_jdownloads

Mira: en la estructura hay Señal, Radionica, Señal Institucional y arriba hay un jefe, en cada uno de esos canales hay un responsable. La Radionica y Señal Memoria tiene otro, ¿no?

Sí. Señal Memoria es lo máximo, empezó en el 2013, yo estaba allá, apenas este año está empezando a mostrar cosas.

¿Eso fue tratando del acervo que se tenía? 
Sí, porque el acervo estaba muy bien organizado y catalogado, el de radio, pero no el de televisión, están empezando a digitalizarlo, tienen una asociación con Patrimonio Fílmico Colombiano, que está en las mismas instalaciones donde tienen las cavas y las neveras para tener todo en buen estado. Pero, por ejemplo, cuando pasó esto en INRAVSION, que cerraron, fue violento porque entonces estas 600 personas se quedaron sin trabajo. Ellos se tomaron las instalaciones y entiendo que se robaron parte de los acervos, se llevaron mucho, mucho, mucho. Fue una forma de protesta Eso nunca se recuperó. No se sabía que había para poder saber qué hacía falta.

En Brasil también hicimos proyectos con bancos de acervo con financiación pública, había muchas cosas y cuando los productores se iban se llevaban las cintas, aunque tenemos muchos materiales e en las radios CDs, pero es difícil de mantener la cosa física, ¿no?

$\mathrm{Si}$, entonces digamos que para mí el mayor logro de los últimos años de allá es Señal Memoria porque sí creo que estaba descuidado todo el tema del archivo de la catalogación. Nosotros tuvimos un subgerente, en el 2007, en televisión que venía de trabajar en Discovery y él tenía una mirada muy clara... él fue el único de todos los jefes que había, que había trabajado en televisión, tenía una mirada muy de televisión.

¿Este jefe está arriba de coordinador?

La estructura es: coordinador de Señal Colombia, coordinador de Institucional, director de Radionica, director de Radio Nacional y arriba de ellos los subgrentes de radio y televisión y arriba de ellos el gerente de RTVC

¿Por que no es director en la televisión?

Porque les parece que costaba más caro poner ese nombre, porque realmente opera uno como director, porque coordinador es otra cosa en mi opinión pero bueno (risas)

\section{¿Por que Radionica tiene tanta importancia?}

Radionica tiene mucha acogida entre los jóvenes, tiene más audiencia.Tiene una apuesta muy clara y contundente.

\section{¿Entonces más plata se va para la radio que para la televisión?}

No, es más barata que la televisión. Señal Colombia es la que tiene mayor presupuesto para producción pero es que los modelos son distintos, porque Institucional tiene un modelo de operación diferente. A ellos no les dan presupuesto como el que viene de la ANTV, sino que ellos venden servicios a las entidades del estado. Ellos producen plata. Luego está, arriba de los dos canales de televisión, está el subgerente de televisión. Arriba de los dos canales, ese es 
el jefe. Y, luego, arriba de los dos de radio hay un subgerente de radio. Y arriba de esos dos subgerentes está el gerente general de RTVC.

¿Ese es más político?

El de arriba, el gerente, ese es político, de RTVC, generalmente es un cargo político. Los subgerentes, en el radio no. En radio, la subgerente ha sido una persona que lleva mucho tiempo y que ha sido muy buena. Pero en televisión si ha habido muchos cambios y ha habido gente que no es tan buena. Ahí es donde te dije que estuvo alguien que trabajó en Discovery y él estaba muy preocupado por el archivo y por los cambios de tecnología. Porque nosotros estuvimos grabando en SD (Standard Definition) hasta que el llegó, el empezó a pedir que se grabara en HD aun cuando no se emitiera en HD (High Definition) y empezó a pedir que en el manual técnico se exigiera aun entrega en donde hubiera un master en HD y otro en SD. Y se entregaran también los roches de ciertas cosas de la grabación, pero no había una política de archivo. Entonces recibíamos todo y era debajo del escritorio de tráfico y ahora con Señal Memoria se espera que sí, haya una política de archivo.

Cuando yo era gerente de la Radio MEC en Brasil había un acervo inmenso. Cuando escribí el libro de TV para Beth Carmona descubrí que durante la dictadura todos los programas que había, que eran sobre cultura y más críticos, los dirigentes exigieron que los borraran todo, algunos tuvieron la idea de colocar en el nombre de la cinta "Fútbol" para engañar, y no los borraban. Más tarde, cuando trajeron equipos nuevos, abandonaron los viejos, pero se guardaron los acervos, los materiales antiguos, que sólo eran reproducidos por esas máquinas abandonadas. Entonces era necesario mantener aquellas máquinas, y algunas televisiones han abandonado.

Sí, aquí se llevaron muchas cosas y había cosas que no había como verlas, equipos para poder verlas y entonces no sabíamos que había.

Algunas empresas creo que hacen la recuperación de cosas antiguas pero es caro.

Creo que además también en la televisión privada no había políticas de archivo, entonces Señal Colombia también empezó con una estrategia de programación de recuperar programas que se habían hecho en la Televisión Nacional hace 20 años, comedias que habían sido un hito dentro del país. Y se encontró con que había muchas cosas con que no tenían los archivos Yo hice un estudio en artes de América Latina sobre una criticas de arte más importante y había un programa en Señal, era una Argentina, Marta Traba, que fue casada con un Uruguayo (Angel Rama), ella vivía aquí en Colombia, murieron en un accidente de avió... ella hacia crítica de arte para la televisón. Y salía por la calle con la gente, hablando, y la gente junto, era una forma de llevar el arte a los pueblos. Y, con eso, más 
aún empezó a mostrar que la gente tenía que empezar a salir. Un día estaba en un lugar y otro, en otro lugar, siempre con la gente, no sé si la gente la entendía pero... Hay programas de ella en Museo Nacional

Fue muy importante el trabajo de ella para el arte contemporáneo, en ese momento fue muy importante. En el museo de arte moderno creo que también tenían algo, en el canal estoy segura de que se perdieron muchas (14:11) cosas importantes. Y, de hecho, un programa que fue muy bonito al principio que se llamaba Remedio para la memoria y era con los archivos viejos mostrando los primeros aviadores, los carnavales. Eso lo hicimos en el 2004 pero recuperando archivos antiguos, mostrando como era todo. Ese programa tenia éxito, a la gente les gusta mucho ver esas cosas.

Siempre creemos que las cosas buenas son las que están sucediendo hoy y que antes no era así, entonces creo que es importante que los jóvenes miren que ha habido gente importante.

Yo creo que hay otras 3 cosas que son claves dentro del canal;

- Una es el trabajo de descentralización se planteó desde el 2007 y aun todavía permanece una franja regional, que se llama Colombia desde adentro. Ella empezó porque el canal empezó a producir fuera de Bogotá, se empezaron a hacer talleres de formulación de proyectos en 9 o 11 ciudades donde había facultades de comunicación, donde había canales regionales buscando un poco el desarrollo del sector. Porque siempre que se presentaban perdían porque no sabían escribir los proyectos, entonces empezaron esos talleres, se les entraban a las universidades las metodologías para que ellos las empezaran a desarrollar. Igual se presentaban y tenían puntajes muy bajitos, entonces lo que hicimos fue inventarnos una franja sólo para ellos para que no tuvieran que competir contra Bogotá, que había más desarrollo desde la parte de escritura y de todo eso. Y empezó un proyecto como... con unos contenidos que siempre les faltaba un poco pero, pues, igual años tras año empezaron a mejorar y, después de 3 años, ya los contenidos eran comparables con los nacionales - no en todos los casos. Y empezaron a poder presentarse a las convocatorias nacionales a competir y a ganar y a ser muy importantes dentro de sus propias regiones.

- Otra cosa fue el mercado de coproducción, fue en el 2011, una manera de organizar que el canal recibía muchas propuestas de productores independientes que decían: "tengo adelantado esto, ustedes que me dan, como le podemos hacer". También por los pedidos políticos, gente que el gerente decía: "viene esta persona con este proyecto". Entonces dijimos, bueno, vamos a formalizar esto de tal manera que el canal organice en un 
calendario anual cuando recibe proyectos de coproducción y en qué condiciones. Entonces también pusimos un mínimo de calidad, que es bastante alto, más alto incluso que la producción nacional porque si es internacional es algo que queremos que tenga visibilidad internacional. Esto se hizo de la mano con el trabajo que hacía Claudia Rodríguez. Porque Claudia empezó a trabajar en el canal en esta época y ella empezó a asistir el mercado internacional, a muestras y festivales, internacionales no solamente en América latina, sino también en Europa y en Estados Unidos (19:07). Y entonces lo que se hizo fue empezar a hacer una convocatoria anual de coproducción en donde el canal tenía una bolsa de dinero destinada a distribuir en los proyectos que más le interesara, que pudieran tener proyección internacional, proyectos que el canal no podía hacer solo porque era muy costoso. Y de ahí fue que se empezaron a hacer la mayoría de proyectos infantiles, porque los proyectos infantiles son costosos y son más largos. Empezamos a producir con Argentina, con Pakapaka, con Brasil también, se hizo Migropolis... En fin, se empezaron a hacer coproducciones que pudieran tener mayor proyección en distintos canales de América latina o incluso se hizo un programa infantil con Francia o con Inglaterra que se llama La pregunta que es carísimo y es espectacular y nosotros pusimos 9 mil euros y pudimos ser socios. Este programa está en español, en inglés y en francés. Es un proyecto que viene de un libro Francés. Claudia lo consiguió, ella cazaba proyectos en distintos mercados y los traía. Entonces allí se presentaban proyectos destinados a productos colombianos y otros internacionales, ellos lo que hacen es presentar el grado de desarrollo en el que esta cada proyecto y el grado de financiación y el canal lo único que pide es que sea el último que cierra el negocio para poder garantizar que es viable. Porque si le falta, pues, puede pasar mucho tiempo. Claudia (Rodriguez Valencia) está en Señal y creo que continua haciendo eso, Jaime también, yo casi no viajaba, Claudia estaba destinaba a eso.

\section{Me acuerdo mucho de Claudia en Brasil, en el Comkids}

Este mercado fue el que siento yo que catapultó a Señal, por permitirle hacer unos proyectos de otro nivel. Sola no podía hacer y empezó a tener visibilidad en festivales y ganó respeto afuera y adentro.

Creo que eso ha influenciado a los productores, yo soy encantada con las producciones de Señal. Y me acuerdo que Claudia (en los festivales Comkids) entraba de primera y se quedaba sentada viendo todo, con mucha atención. Siempre la gente de Colombia, algunos salían, pero los colombianos siempre se quedaban mirando todas las programaciones.

Sí, yo estuve solamente en el año 2013. 
Aquí es cada cosa linda, que tratan de las diferencias. Ahora en Brasil están con programas de Señal, eso es muy bueno porque cuando hacen la evaluación ellos pueden decir que estan influenciando Brasil, para las directivas políticas eso es sensacional

Sí, Guillermino y Candelaria lo vi en portugués y me pareció lo más bonito, en portugués suena más bonito que en español

\section{¡Es un éxito! La Lleva me encanta también, ¿todavía está al aire?}

No, esa fue anterior, empezó cuando era productora delegada. Fue una idea desde el Ministerio de Cultura, cuando estaba Guiomar. Cuando empezó había un grupo que es el que hoy dirige Diana, que es de Televisión para infancia y juventud.... ¿pues, cómo es que se llama el equipo de Diana? (pregunta, no saben, pero después le informan: Comunicación Cultural y Niñez - Mi Señal). Ese equipo empezó desde que estaba Guiomar, mi jefe, y llevó tiempo que es que empezaron a hacer investigación y a escribir televisión infantil. Y La Lleva fue el primer contenido que salió, German Franco era el que estaba en ese momento.

Las convocatorias contemplan la parrilla de todo el año, ¿hay algunos momentos que no tienen cosas nuevas que poner, hay dificultades para hacer la parrilla?

Nosotros, en la época que yo estaba, empezábamos a diseñar la parrilla del año siguiente en el segundo semestre del año anterior. Y lo que hacíamos era proponer cuales son las temáticas anuales que tuvieran que ver con la historia y con la coyuntura de efemérides importantes que fueran significativas para la vida nacional. Este año, por ejemplo, los 30 años de Palacio de Justicia. En los años anteriores tuvo que ver con el asesinato de Jaime Garzón; o con un deportista que ha ganado la vuelta España, el único colombiano; temas que se buscara también que tuvieran... el año de la energía, que fue como el 2012. Se buscan temas generales que puedan ser explorados desde distintos ángulos durante todo el año para poder escribrir las convocatorias y que se abran muy al comienzo del año y se puedan ver hacia el segundo semestre de ese año.

Planean y, ¿si hay alguna cosa, una referencia de algo muy importante que ocurrió en otro momento, lo colocan ahí?

Sí, hay una modalidad de contratación que había que se llama Administración Delegada que es como una bolsa. Y entonces hay una para especiales culturales y otra para especiales deportivos. Y en la de especiales culturales era donde había la posibilidad de reaccionar inmediatamente. Había un programa diario, que te dije que quitaron, se llamaba En órbita que ahí es donde se podía cubrir para una coyuntura. Ese programa tenía una parte en radio, el presentador iba a Radionica por la mañana, a Radio Nacional por la tarde, tenía el programa de TV que salía 4 veces al día en capsulas de 15 minutos y la página web donde estaba todo. 
Lo que pasó en Paris, en este momento, por ejemplo, los ataques, no he visto en la Señal. ¿La gente no tiene el derecho de saber que está pasando, todo, lo que está ocurriendo en el mundo?

En Órbita tenía la Agencia F, tenía corresponsales en Europa y en Estados Unidos, era mucho más relacionada con cosas culturales pero también coyunturales.

\section{Sobre no tener perdiodismo. En esos dias tuvo que mirar a RCN para saber que pasa en} el mundo. Y habla de la falta que hace "en Órbita" ¿Cómo fue creado?

Nosotros contratamos un equipo (....) teníamos la inquietud de hacer algo que fuera convergente pero no sabíamos todavía bien que significaba eso. Porque todo el mundo dice muchas cosas, pero no hay nadie que lo esté haciendo y todavía es algo muy gaseoso. Lo que nosotros planteamos fue, bueno, esta empresa tiene dos emisoras de radio, dos canales de TV $\mathrm{y}$ podemos tener un sitio web. Entonces, la persona que nosotros trajimos a diseñar el contenido fue Claudia Bautista, la misma persona que desarrollo $L a S u b 30$, que funciona muy bien, y la que dirigió La Lleva. Y dijimos bueno ¿Y qué podemos hacer? La contratamos a ella y a otros dos creativos durante 3 meses para que estuviéramos botando corriente y ver qué tipo de cosa podía surgir. Entonces lo que planteamos fue "bueno, por el momento lo que podemos hacer es una cosa que sea multiplataforma, o sea un programa, que pueda tener unos contenidos que se desarrollen de una manera diferente, de acuerdo a las características, lenguaje y posibilidades de cada medio. Entonces si, por ejemplo, hacemos una entrevista con Totó, La Momposina, podemos hacer entrevista para radio; podemos tener para TV un trozo de un concierto; podemos tener para la web unas fotos y una selección musical para que la gente la descargue en MP3... se empezaron a buscar maneras de articular. Y era muy difícil porque de todas maneras las lógicas de producción de cada medio son distintas, los tiempos. Pues fue algo muy difícil, era ensayo error, salía más caro, era difícil.

También lo que empezamos a notar fue que se hacían unas piezas de colaboración, en donde la gente hacía cosas, empezaron a mandar cosas y lo que empezó a pasar en la web era interesante porque había un acervo vivo, online, de todas las cosas de cultura que estaban pasando. Y que podían estar en video, que podían estar en audio, se hacía infografía, periodismo digital. Eso duró un año y medio y estaba empezando a mutar y a madurar, lo quitaron. Todavía le faltaba madurar pero dijeron que no, que resultaba costoso. Pues no sé bien cuáles fueron las razones pero después de que lo cortaron ese proyecto ganó premios de la RED TAL Televisón América Latina, concursos en Europa como una iniciativa convergente. Lo que yo sé es que en este momento en el canal cuando van a congresos internacionales lo muestran como caso exitoso pero lo quitaron, entonces no entiendo. 
Son los casos de discontinuidad. Eso es más desconstrucción que discontinuidad. Planea, invierte y después para...

La otra cuestión que se diseñó durante...más o menos entre el 2012 y el 2013 fue Mi Señal, que es la programación infantil, pero en la web. Entonces en el mercado de coproducción, en las coproducciones, cuando nos empezamos a dar cuenta del tema de convergencia y toda la cosa tecnológica, no sabíamos cómo hacerlo tampoco porque ni nuestros productores ni nosotros éramos productores de APPs, ni video juegos, ni nada, entonces lo que empezamos a hacer fue a ponerle en el contrato a todos que se necesitaba desarrollar 3 contenidos derivados que podrían ser un juego de tales características, o actividades, o en fin, lo que sea.

Uruguay también tiene algunas cosas interesantes, hay un canal que lo hace para las escuelas, todos los niños reciben un kit de equipos para acompañar la TV.

Si, esto fue lo que se hizo y a cada uno, a Max Rodríguez, al Show de Perico, a todos que eran nuestros coproductores les empezamos a pedir que entregaran juegos. Entonces esta web se puede filtrar por programas o por los contenidos. Entonces hay juegos, entonces tú puedes entrar acá... Entonces ellos tuvieron también que aprender porque tampoco sabían o asociarse con otros ramos del sector. Cuando estuvimos en Comkids mostramos - Guillermino y Candelaria tiene libros para pintar, tarjetas de cumpleaños, cosas para que los niños recorten, para que los coloreen.

\section{¿Y hacen una evaluación de eso?}

Ellos tienen, ahora, hay un área que hace toda la métrica de web y televisión. También hay videos en la web, hay descargas de canciones, wall papers, ring tones, unas actividades para poder colorear etc.

\section{¿Están bien desarrollados aquí en Colombia los desarrolladores de games, no?}

Sí. También salió una ley, pues un CONPES, que es como un decreto en donde se piensa que puede ser una industria de exportación, le han metido mucha plata para que la gente haga emprendimientos alrededor de eso, las canciones... Entonces esto fue algo que empezó también a producirse uno a uno. Entonces los productores era: "que yo no sé hacer eso". Entonces vas a empezar a hacerlo. Ellos ahora ya están inventándose los programas incluido todo eso. Saben que tienen que sacar unas canciones, que se las pueden vender, que tienen cosas para colorear... Y, gracias a eso, este espacio se enriqueció para los niños. Así es, esas son las cosas como se hicieron que creo que vale la pena tener en cuenta (39:16)

(cuento de charla con Beth) Trabajar con TV para niños es muy enriquecedor, la importancia de la audiencia de niños. Y hay proyectos importantes, como Pakapaka en 
Argentina, en riesgo por el cambio de gobierno. Habla del encuentro organizado por el canal en Buenos Aires “Otra televisión es posible”. Y muchos han percibido en el canal que la gente estaba muy preocupada con eso, con toda la chance de que se cambie todo con el cambio de gobierno (Macri)

Sí, yo estuve en Chile, estuve con Facundo Agrelo, de Pakapaka, y sí estaban preocupados por el tema. Y entonces estaban poniendo todo el manifiesto de televisión en las redes sociales.

Ellos están preocupados con lo que todo mundo piensa. ¿Tienes algo más a decir sobre la programación?

Pues, no sé, tantas cosas que había. Pienso que con eso ya estamos, si encuentro, te envió.

¿Qué piensas tú de cómo será el futuro de la televisión pública, que se va a hacer o que se puede hacer para preservarse? Por que Omar Rincón ha dicho que la televisión pública ha fracasado, la TV educativa es del siglo pasado y no cree en los formatos. Yo creo que como la Señal está diseñada, con las producciones independientes, la innovación siempre es un camino. Por que en Brasil lo veo como un elefante blanco, mucha gente perdida pensando una cosa diferente y no se compromete. Cuál es la salida para la televisión pública en Latinoamérica y en todo, que sugerencia tienes tú, que manejaste tanto tiempo, primero en relación a las indicaciones políticas, como hacer para tener independencia que tampoco creo que la BBC la tenga.

Siempre creí que para que estuviera preservada de esa mirada política-coyuntural debería haber un plan a 10 años por lo menos, que se tendría que estar renovando, con unas metas que se pudieran vislumbrar cuáles son los cambios sociales, culturales y tecnológicos que se venían adelante, que implican una investigación y una mirada de todos los medios del mundo para ver a donde apuntan y tratar de hacer un plan a por lo menos unos 10 años. Porque siento que si no hay un plan y una estrategia de mediano y largo plazo todo se vuelve tratar de conseguir unos resultados inmediatistas. Entonces pasaba una cosa muy mala y es que los jefes de arriba, cuando empezó a haber premios, empezaron a poner dentro de los indicadores y las metas de acción "número de premios". Pues que ¿yo como te puedo garantizar que nos vamos a ganar premios? Lo importante no es ganar 5 premios, ni 18, lo importante es tratar de hacer las cosas bien, gane premios o no gane premios. Era como una mirada en lo que no debe ser, digamos que un plan estratégico planteado en términos de tecnologías, de temáticas... En este país, en este momento, pos conflicto, si se firma la paz. Siempre tratar de ver un paso más adelante y tratar con todos los cambios tecnológicos, el consumo de televisión ha cambiado y creo que es importante tratar de hacer otro tipo de contenidos. También había un preacuerdo 
con la National Film Board de Canadá, que son como los pioneros en convergencia, estaba ya firmado y también eso se cayó, que era un tema para que nos enseñaran a hacer convergencia. Creo que por un lado está la planeación, que no es siempre que pasa, pues que esté por encima lo público y no el gobierno, y que pudiera ejecutar un plan que sea más a largo plazo, que sea evaluado si está funcionando, que se pueda ajustar para mejorar; poder tener las capacitaciones en las instancias y en los eventos internacionales para tener retroalimentación y que haya una producción innovadora en otros medios. Y, posiblemente, coincido con Omar en que tendría que haber una migración hacia otro tipo de estrategias y de pantallas, porque creo que el tema de la TV pública en América Latina y en Colombia es que por los presupuestos también siempre ha estado rezagada y nosotros nunca pudimos hacer ficción porque el presupuesto anual es lo que cuesta un mes de ficción de un canal como RCN o Caracol. Entonces, hacer ficción con poca plata es terrible, la audiencia lo nota inmediatamente.

Por ejemplo, sí fuimos buenos haciendo programas de nicho y el consumo es de nicho cada vez más en la redes. La TV cultural debería ser para todos pero finalmente los que están excluidos en la TV privada son minorías, que no se ven reflejadas ahí, trabajar hacia esos nichos puede ser interesante. Los jóvenes están excluidos de la TV porque ellos no tienen poder adquisitivo y no hay mucha programación para ellos. Pero si uno tiene contenidos interesantes en televisión y que tengan cosas complementarias puede ser interesante, donde se vean ellos. La TV cultural creo yo que la misión principal que tiene es la de visibilizar lo que no está visible en otros canales. Y eso parece que nunca fuera a cambiar. Entonces, ya los jóvenes buscan ser visibilizados en otros espacios y empiezan a sentirse identificados. Por ejemplo, acá, los negros del Pacífico, uno va al Choco y tienen unas estéticas mucho más parecidas a las de New York, en el Bronx, es estética del Hip Hop, pero es que aquí no les estamos dando nada. Entonces es poder buscar esos nichos pero necesariamente dialogar con las nuevas, pero no sólo son los aparatos, sino son las maneras de interactuar. Y por eso se necesita trabajar con gente muy joven, yo siento que los creativos tienen que ser muchachos muy jóvenes que entiendan muy bien cómo funciona esto. Y no uno de 46 años tratando de decir, no, eso es así...entonces hay que enseñarle a uno como es la cosa.

¿Cuál es el perfil de directiva de la TV pública y como se podría hacer la selección si no fuera por el gobierno? Por que en Brasil es el consejo administrador que son 5 ministros y no pasa por los otros. ¿En tu visión cual sería el perfil y como escogerlos?

Yo creo que debería ser una persona que pueda tener conocimiento de narrativas, audiencias, de formas de consumo y de tendencias de los medios públicos de todo el mundo. Que no 
tenga una mirada limitada al país únicamente, sino que pueda entender toda la cosa globalizada y que entienda también de temas administrativos sin que se tenga que dedicar a ellos. Porque lo administrativo es el gran enemigo de lo que se puede hacer o no se puede hacer. En el caso de Señal Colombia, muchos de los cargos eran más administrativos que creativos o conceptuales, no había mucho criterio para poder decidir cuándo una cosa era buena o mala o tenía calidad o no, y ellos simplemente estaban administrando. Un director de un medio público y cultural no es un administrativo, es una persona que aunque tiene que saber administrar recursos, su mayor fortaleza no es esa. Y para eso estaría su segundo a bordo, que sería un productor general o ejecutivo-administrativo, pero su misión es poder conocer de políticas de calidad y de TV y medios, de calidad en el mundo. Y no sólo de televisión, de medios, pues, pensando en toda esta convergencia. Y la forma de escogerlo, yo supongo, yo siempre he diseñado pruebas específicas y en todos los casos se aplica, es decir, que además de revisar la la hoja de vida, puedan hacerle a uno una prueba de por ejemplo un problema ficticio para resolver y proponer. Porque así se puede ver un poco cual es la mirada, que es lo que está en capacidad de proponer, cual es la creatividad... Porque a veces las hojas de vidas son engañosas, la gente puede tener títulos, o puede no tener ninguno y ser sensacional, entonces creo que una hoja de vida no basta.

\section{¿Quien haría esta selección, como librarse del gobierno?}

Ese es el problema porque los comités técnicos, en las juntas directivas, generalmente son los mismos con los mismos, entonces es difícil. De ahí para abajo nosotros, también, dentro de todas las metodologías que hicimos en el canal, sacamos un manual de roles y perfiles de qué es lo que uno espera de cada uno de los cargos, y cuál es la contribución y cual es el perfil. Generalmente hacíamos pruebas a casi todos los cargos. Y nos inventábamos pruebas prácticas - "tenemos esto y esto, dime como lo resuelves". Y lo mirábamos. Y eso no era necesario, legalmente. Nos decían los jefes: ‘“ustedes porque se enredan tanto así, en todo”! La ley, lo único que pide es que tengas tres candidatos y generalmente ya tienen escogido un candidato o otro. Nosotros hicimos pruebas muchas veces para diversos cargos tratando de identificar...también afinidades. Hacia los principios y los valores del canal

Marcela, muchas gracias, ;fue muy bueno! Me fui a un seminario que fue promovido por el Consejo de curaduría de la EBC (Conselho Curador) que no tiene el mínimo poder, todo el poder está concentrado en su presidente y en su dirección y el Consejo de Administración que tiene como 5 ministros y un representante de los empleados. También el Consejo Curador tiene representación de los trabajadores y este consejo hoy tiene representación también del movimiento de las mujeres de los afros, de los 
discapacitados, tiene representación de todos, pero es una cosa no tiene injerencia en la programación; los funcionarios que están en la huelga, en este momento, hicieron y mandaron una carta al Conselho Curador, con reivindicaciones y denuncias. Tenemos mucha preocupación, es una lucha bien ingloria como dicen.

Gracias querida por su atención. 
APÊNDICE E - ENTREVISTA: ADELAIDA TRUJILLO - Co-directora de Citurna Producciones y Fundación Imaginario

Entrevista grabada en 21/11/2015

PERFIL: Adelaida Trujillo Caicedo estudió antropología en La Universidad de Los Andes y se especializó en cine y televisión en la London International Film School y la BBC de Londres, con una beca del Consejo Británico (1987-89). Trabajó en el Departamento de Música y Artes de la BBC. En 1986 con Patricia Castaño y Doris Eder, fundó Citurna Producciones - casa productora líder en Colombia en cine y televisión documental, televisión escolar e infantil. En 1999, con Patricia Castaño y otros socios fundó Imaginario para trabajar de manera más amplia e interdisciplinaria con la televisión, los medios y la comunicación, como parte de estrategias para la educación y el cambio social, con foco en las audiencias infantil y juvenil, a nivel local, nacional e internacional. Desde el 2007 Imaginario y Citurna se han especializado en la la implementación de plataformas de eduetretenimiento multimediales para el cambio social y de comportamiento en derechos sexuales y reproductivos y prevención de embarazo adolescente.

\section{Adelaida, ¿en su opinión lo que falta en la televión publica hoy?}

Yo creo que la calidad de la producción está bien, la calidad de lo que se está haciendo está bien. Pero me parece que falta el debate y la convocatoria de los otros actores, faltan eventos de discusión donde la política pública se pueda discutir, falta esa intersectorialidad. Creo que la TV pública la hacen muchos actores, incluye la academia, los productores, pensadores, la sociedad civil - como nosotros, la gente que está en la educación. Yo creo que ha perdido ese sentido que tuvo cuando hicimos el Compromiso (Nacional por una Televisión de Calidad para la Infancia), por lo menos en cuanto TV infantil, en que uno vinculaba todos los sectores y discutía y ponía sobre la mesa a todos los actores. Entonces ahora está muy restringida a Señal Colombia, al sector público. Creo que falta ese nivel de discusión y creo que lo que está faltando también es que están separados Ministerios de Comunicaciones con las nuevas Tecnologías del Ministerio de Educación, cada uno está trabajando un poco desarticulado otra vez, y ahora con la interactividad, la web, los medios sociales y las multiplataformas, yo creo que tiene que haber un debate otra vez sobre el contenido, y la política pública sobre eso.

El actual cordinador (novembro 2015), Jaime Tenorio, me ha hablado ... ese es el momento para llamar a todos y hacer una discusión. ¿Estás de acuerdo? 
Claro. Yo creo que se tiene que volver a armar el debate. Estamos muy orientados a la producción. Yo pienso que Señal está haciendo una buena calidad de producción pero está muy dedicada solo a producir. Creo que tiene que ampliarlo un poco más.

\section{Hay convocatórias pero no se produce nada allá?}

Claro, son con terceros. Pero si tú produces con terceros los tienes que vincular como sector. Yo ya estoy completamente desconectada del sector como tal, es decir, nosotros hemos sido líderes en producción y en innovación. Sigo haciendo mis cosas, trabajando con el Ministerio de Salud, Ministerio de Educación, financiación internacional, pero ya hace rato no trabajo con Señal Colombia. Porque tú te presentas y no te escogen, y aunque no se ha seleccionado, pero era convocar, vincular, mantener en el debate, está un poco cerrado. Hay unos productores que están dominando la programación y ha cerrado un poco el espectro. Debería haber más gente involucrada.

\section{¿Incluso la gente que tiene gran experiencia con los nuevos?}

Está bien que estén vinculando a los jóvenes, me parece perfecto. Tiene que tener esa experiencia juntos. Por lo menos para ampliar la mirada, es decir, el productor joven solo piensa en su producción, no tiene la idea de conjunto, del sistema, no piensa en los fondos, no piensa lo que va a pasar a futuro, está solamente concentrado en lo suyo.

\section{¿Y cómo ves la indicación de los dirigentes por parte del gobierno para RTVC? En Brasil, en EBC, todavía falta autonomia. ¿Cómo una televisión que es de la sociedad debería tener la indicación de sus directivos?}

Yo creo que en Colombia está un poco menos politizado que en Brasil. Yo creo que hay menos tendencia a que el canal - RTVC - sea propagandístico del gobierno de turno. Yo no creo que eso pase tanto acá. Pasa más en los canales regionales, está pasando en TeleAntioquia, eso se está dando más que el gobierno porque como son canales que tienen que ver con las gobernaciones. Yo creo que en lo regional no se está pasando más que a nivel nacional. Porque Canal Capital, hasta estos 4 años, son muy del alcalde, y ahí es más abierto, más pluridiverso, plurienfoque, y así ha pasado en TeleAntioquia. Yo creo que Señal por lo menos tiene claro que tiene una Señal cultural y educativa y otro canal que es Señal Institucional. A mí me parece que eso está bien, por lo menos tú sabes que en ese canal está Congreso, los gobiernos, los Ministerios haciendo su tema institucional. Y eso pasa menos acá que en Brasil. Pero sí me preocupa que se nos esté abriendo, que no haya espacios de debate. Aunque hay algunos, me parece que se repiten, no hay innovación en el tema. Omar 
Rincón está más metido en la academia, los Martínez que estaban dedicados iban a retirarse. Entonces quienes lideramos ese debate ya no estamos. Yo creo que ya hicimos la tarea, y yo creo que ahora falta alguien que haga eso que nosotros hicimos en un contexto, 10 años después. Porque si tú pienas, el Compromiso ya va a cumplir 10 años. Alguien tiene que tomar esto y actualizarlo. Nosotros estamos en la línea de edutainment, de impacto, de cambio, y con eso tenemos mucho que hacer. Pero sí lamento que quien está tomando la bandera un poco. Eso es muy triste.

\section{¿No son ustedes otra vez que deberían encabezar el movimiento? ¿no tienes ganas de hacerlo?}

Ahora yo estoy muy preocupada en lograr datos de impacto sobre comunicación, estrategias de comunicación con TV. Eso me parece que ya es un debate complejo en sí mismo. Porque ahora que nosotros nos salimos un poco del sector de la tele, estamos tratando que el Ministerio de Salud, por ejemplo, en vez de invertir toneladas de millones de pesos en campañas para hacer estrategias de TV, edutainment, comunicación, educación que se puedan medir.. que sean más constantes, que se puedan medir y que generen cambio de comportamiento. Estos son procesos, plataformas, de largo plazo y estamos viendo, con nuestra última serie, (que te voy a copiar aquí en los documentos) que hemos generado cambio de comportamiento. Los chicos que ven programas son mejores en matemática, los chicos que ven Revelados se ponen condón, hablan de sexualidad con sus padres, en fin, estamos viviendo un impacto en el comportamiento individual y social, ahora como que estamos en esa nueva esfera.

Y es interesante lo que tú hablas de cosas de la salud que se confunden con las de educación

Estamos mucho en lo que se llama hoy Social Behavior Change Comunication. Esa es la tendencia internacional y en eso estamos nosotros. Entonces por eso, y como es un tema complejo, ya estar en ese debate es suficiente.

\section{En Brasil el Ministerio de Salud gasta mucho plata con publicidad haciendo divulgaciones de campañas temporales. Por ejemplo, sobre el dengue hacen campaña pero no cambian comportamientos.}

(Adelaida le enseña el plano estratégico para el 2007 que hicieran con el Compromiso y vuelve a hablar sobre Señal). 
Sí, yo creo que lastimosamente está faltando ese debate, yo siento que Señal Colombia está muy cerrado. Creo que años después están finalmente logrando estar en festivales, en sitios como comKids, en Prix Jeunesse, entonces han ganado premios importantes. No basta ganar premios... yo creo que aquí hay que tratar de que se promuevan mucho más, yo creo que hay que hacer mucho más trabajo de promoción, hay que invertir más en promoción, en escuelas, en divulgación en medios sociales, eso yo creo que es el gran faltante. El debate sectorial de la multimedialidad, de las nuevas plataformas, de la interactividad, de los nuevos medios, de los medios sociales, todo ese debate, para donde vamos, y la promoción...

Por eso que es tan importante guardar todos estos documentos (Adelaida mostra as várias salas com material preservado).

Si viene alguien y retoma ese legado y no lo puede retomar. Lo que pasa es que son esfuerzos muy grandes y cuando tú sientes que por ejemplo, hoy, Señal Colombia no te reconoce, no te invita y tú dices "bueno, pero ya", si no les importa, bueno...

Compromiso: yo creo que hicimos una buena base pero que se puede perder si no se actúa.

(Adelaida mostra outros documentos) Esto es después de TV de Calidad, en 2000-2008. En el 2009 empieza la muestra iberoamericanas y ahí se disuelve la Comisión Nacional de TV y se pierde el esfuerzo.

(Adelaida enseña Compilación de propuestas que trajeron para la mesa.. cosas que de afuera.. evaluación de la TV infantil, eso fue una preocupación nuestra.) Estoy muy metida en el tema de la evaluación.

Uds empezaron haciendo documentales para adultos y luego para niños. ¿El Compromiso con la TV pública fue direccionado para los niños?..

Creo que son nichos distintos. Yo creo que también se necesita tener un foco para adultos. Nosotros, personalmente, nos enfocamos en niños porque creemos que ahí es donde se puede generar mucho más cambios. Hoy, nosotros estamos muy concentrados en jóvenes.

\section{En Brasil está Beth Carmona a preparar produtores...}

Ustedes en Brasil tienen una buena participación de la sociedad civil.

\section{Hable sobre las produciones de Citurna.}

Hacemos Franja Metro que tiene ese carácter educativo, interactivo, público donde programamos muy buena TV porque tenemos las licencias de emissión de todos esos 
provedores, Channel 4, BBC, Kimbersly ... nosotros hacíamos producción nacional, que era solamente 1 hora. De las $3 \mathrm{~h}$ nosotros producíamos original $1 \mathrm{~h}$. La otra hora en estudio, en el set, con El boneco de Hugo, interactivo, invitaba a los niños; Y la otra hora era de licencias internacionales.

La Franja era 3h: 1h local hecha por productores locales, otra en vivo y la otra $1 \mathrm{~h}$ de internacional, de licencias de TVs educativas, de muy alta calidad. Todos los días teníamos $1 \mathrm{~h}$ de El boneco de Hugo en vivo. La escuela de la que tú hablas, el training, de toda esa gente que empieza a pensar la TV infantil. Realmente empieza con Franja Metro. Porque antes El Rincón del Cuento, Jungla del alfalto, Viva Bogotá Viva, y otras producciones que habíamos hecho, pequeñas, eran como Boutique, pues teníamos más tiempo, más dinero, pero en Franja Metro eran todos los días, y teníamos que entrenarlos, entonces pasó mucha gente por acá, eso armó como una escuela pero también generó impacto en Bogotá. Lamentablemente Franja Metro no la continuaron cuando entra el otro alcalde (él se quedó 2 años). Nosotros la tratamos de vender, pero al otro lado Inravisión, porque todavía no existía Señal, no teníamos interlocutor, no había con quien. Allá no estaba formado nadie.

\section{¿Qué transmitía Inravisión en esa época?}

No me acuerdo, pero durante mucho tiempo Inravisión cedía espacios a concesionarios. Entonces podía haber porquerías...En eso (tiempo), nos llaman a participar en un grupo que la Fundación Rockefeller convoca en el 1997, por primera vez, un gran debate internacional sobre la Comunicación para el cambio social. Fue un gran conferencia que invitaron a unas 20 personas en el mundo y me invitaron a mí, a nosotros por la experiencia que teníamos con El Rincón del Cuento, Jungla del alfalto.

\section{¿Era un debate sobre comunicación?}

Sobre comunicación y desarrollo y sobre comunicación y cambio social. De aquí salió el Término "comunicación y cambio social" y desde entonces somos parte de ese grupo. Yo fui la que más me involucré en ese debate. Estas son las personas invitadas (muestra el doc que entregó Liana). Pero lo interesante aquí, y por eso te lo traje, es que aquí fue cuando nosotros empezamos. Esto coincidía históricamente con lo que yo te estoy contando, es decir, habíamos hecho exitosamente Jungla de Asfalto, teníamos 7 entradas en el canal y mucha incidencia. Pero no había la política, no había plata para fomento ni capacitación, no había un pensamiento sistémico. Eran esfuerzos aislados. Entonces Franja Metro nos demostró, mira la fecha, más o menos coincide. Vale la pena decir que podíamos a ver con la Secretaría de 
Educación, y nosotros en Franja Metro hicimos una conexión directa con la Secretaría de Educación, en ese momento la secretaria de educación, que después fue la ministra de Educación durante 8 años, fue muy buena. Ella entendió el concepto, ella entendió que si ella tenía un canal, Canal Capital, público, y era miembro de la Junta Directiva ella tenía obviamente incidencia sobre el contenido del canal, si quería, y que ese canal podía llegar gratis a todos los estudiantes vía escuela o vía hogar, que obvio, el sistema de TV escolar era facilísimo de montar, entonces nosotros hicimos unos experimentos con la Secretaría de Educación muy interesantes, y ahí empezó otro proyecto nuestro, que se llama APTV (Aprender TV) - “Aprender a prender TV, que en español es un juego de palabra e hicimos la sigla. Esto fue lo que empezamos a (Liana interrompe pra pra perguntar em qual secretaria foi): Sec de Educación del gobierno de Peñalosa de la Alcaldía de Bogotá) en el 1998/2000, cuando estamos con Franja Metro. Entonces estaba que la secretaria de Educación que después fue ministra, Cecilia María Vélez, dijo "listo, hagamos el ensayo!". Ella sí nos entendió. Y nosotros hicimos una evaluación de estos contenidos en tantas escuelas. Ahí empezamos a evaluar. A tratar de ver el impacto de esa tele educativa en los chicos, en los niveles de aprendizaje, en cómo los docentes se entrenaban.

\section{¿Fue el momento más fuerte de la TV educativa?}

Sí. No sé porque. De todas maneras ahora viene parte de la historia, porque después Cecilia María pasa al Ministerio de Educación y dura 8 años allí. Y yo creo que ahí se fortalece a nivel nacional el concepto de TV educativa porque ella viene de haber hecho, en el districto, el ejemplo de APTV y ellos empiezan a montar, en el Ministerio de Educación, una unidad de TV educativa, que existía pero era muy pobre, muy floja, muy pequeña. Y allí se empieza a fortalecer toda una línea de uso de la tele. No me acuerdo cómo llamaban las unidades pero allí hubo todo un pensamiento sobre como el Ministerio de Educación se vinculaba de una manera mucho más estructurada a Inravisión, a RTVC. Y ahí hay una serie nuestra que se llama Chinkanarama - fue la primera producción totalmente hecha con el Ministerio de Educación de Colombia en 2005. (gobierno de Álvaro Uribe) 
APÊNDICE F - PATRICIA CASTAÑO - Directora de Fundación Imaginario e Citurna Producciones

\section{International)}

Perfil - Estudió trabajo social y comunicación rural en los años 70 en Colombia, Inglaterra y Holanda, con becas de los gobiernos británico y holandés. Después de una intensa carrera en estudios socioeconómicos y de desarrollo en el país y América Latina a través del IDRC (International Development Research Centre ) - CRDI (Center de reserches pour le développement International), se vinculó de lleno al tema del cine y televisión documental y educativa a mediados de los años 80. Gracias a una beca honorífica del Consejo Británico y su trabajo en Colombia con la BBC y televisión pública y educativa, estudió en Inglaterra cine y televisión con la BBC y la Open University. En 1986, Adelaida Trujillo con Doris Eder, fundó Citurna Producciones - casa productora líder en Colombia en cine y televisión documental, televisión escolar e infantil. En 1999, con Adelaida Trujillo y otros socios fundó Imaginario para trabajar de manera más amplia e interdisciplinaria con la televisión, los medios y la comunicación. Desde el 2007 Imaginario y Citurna se han especializado en la implementación de plataformas de eduetretenimiento multimediales para el cambio social y de comportamiento en derechos sexuales y reproductivos y prevención de embarazo adolescente. Entre el 2000 y el 2004, fue miembro de la Junta Directiva Internacional de INPUT y del grupo de productores latinoamericanos que promueven Prix Jeunesse y desde el 2007 es miembro de la Junta Directiva del World Summit on Media for Children. A raíz del World Summit de Rio en el 2004, promovió la conformación de la Red Colombiana de Medios para Niños y Adolescentes y la estructuración de un plan de trabajo y consolidación de la política pública e intersectorial, a favor de la televisión infantil: Compromiso por una Televisión de Calidad para la Infancia en Colombia.

\section{Patricia, ¿cómo empezó la televisión pública en Colombia? (Habla sobre la Televisión Nacional)}

En todo caso (Televisión Nacional) fue una televisión muy artesanal y muy interesante porque se desarrolló en la Radio Teatro Nacional que es un poco la cimiente de las telenovelas, era tele teatro en vivo. Salían al aire, y de eso queda muy poco grabado. Cuando cayó (General) Rojas Pinilla en el año 1958, en realidad duró muy poco, esta imagen de la TV en poder del gobierno, en poder del establecimiento, y sobretodo en poder de un gobierno autoritario, hizo que inmediatamente empezara la presión para que los particulares tuvieran acceso a la 
programación. Es decir, que la idea de una TV pública se confundió con la idea de una TV de gobierno. Aquí no entendieron que la BBC era independiente, ni Rojas Pinilla ni los demás, no querían que el poder de la TV se lo quedara el gobierno. De manera que desde muy pronto empezaron a hacer licitaciones e invitaciones a ese único canal que había a unas industrias que se llamaron programadoras, las cuales licitaban unas convocatorias, espacios en ese canal, en esa parrilla. Cada día esas licitaciones se volvieron más complicadas y más "políticas" o sea el poder que tenían las programadoras. Curiosamente, los que más defendieron eso fueron los dos primeros directores de la TV en el gobierno de Rojas Pinilla que eran Fernando Gómez Agudelo y un señor que se llamaba Fernando Restrepo Suárez. Por alguna razón Fernando Restrepo, primero era gente de una alta clase social bogotana pero habían trabajado con el dictador (Rojas Pinilla), el gobierno. Ellos fueron los primeros que dijeron: "No. Esto no se puede quedar en manos del gobierno", y vieron el negocio, que era un buen negocio, entonces fundaron una programadora que se llamaba RTI pero luego empezaron a surgir unas 5 ó 6 programadoras importantes y se fueron metiendo en el negocio de la TV Caracol que era una Radio privada, RCN (Radio Cadena Nacional) también privada.

Esto tiene un proceso en el tiempo que yo no te podría decir exactamente, yo recuerdo que como en el 1961 pero no te podría dar la fecha, se hace la primera estructuración de las licitaciones más formales.

\section{¿Cuándo empezó el nombre INRAVISION?}

Antes de INRAVISION se llamaba Radio Televisora de Colombia, todo esto es nacional, pero acuérdate que duran muchos años y que la TV en que estaban cadena nacional de verdad pueda llegar a todo el país porque no era fácil.

\section{¿El nombre era?}

Televisora Nacional de Colombia. Creo que era Radio Televisora Nacional de Colombia. Aquí había algo que se llamaba la Radio Nacional que era muy importante y cumplía una función cultural, no tanto porque recogiera o les interesara las manifestaciones culturales regionales o autóctonas sino más bien era una TV culta y este señor Gómez Agudelo fue nombrado por el ministro de Educación como director de la Radio Nacional, era un tipo culto de la música y estando allá es cuando el dictador Rojas Pinilla lo manda a montar la televisión. La calidad de la TV, a parte que era en blanco y negro, pues no llegaba a todas partes, eso se demoró mucho, y luego en los años 60 una mujer que era periodista muy hábil y muy corrupta de alguna manera creó de una manera ilegal, no me preguntes cómo lo logró, 
cómo lo hizo, pero ella montó un segundo canal que se llamaba Tele Tigre, y ese canal, que fue muy criticado, muy cuestionado, se convirtió finalmente y lo lograron quitárselo a ella (no recuerdo muy bien cómo lo hizo), pero ese canal, que era un canal local de Bogotá, se convirtió en el segundo canal nacional. Entonces lo volvieron a empezar a invertir.

Por otra parte, a mediados de los años 60, en los EEUU, los cuerpos de paz y con intención de ayudar en la educación, se llevaron a una señora (??) que ahora está trabajando en el empalme político y la formaron para ser directora de la TV educativa. Y esa TV educativa fue un canal que se llamaba Canal Educativo, se llamaba la Cadena 3. Esa Cadena 3 era malísima, no tenía recursos, eran clases por TV como si fueran un aula con tablero y eso debió durar... esa Cadena 3 vivió moribunda. Empezó con ese ánimo de modernización financiado por la AID (Agencia Internacional de Desarrollo de los EEUU). La AID, los cuerpos de paz, a partir de ahí fue que salió esto del tercer canal, que era el canal educativo, al comienzo con muchas buenas intenciones que después se volvió una cosa moribunda estatal o sea de todo el gobierno, hibernó y medio se murió hasta el gobierno de Belisario Betancourt en 1982/1986, cuando él, que tenía una cosa muy visionaria en el sentido de que en eso entonces no había ni Internet, decidió que debía hacerse educación a distancia y que había que mejorar las condiciones del canal. Y en algún momento que tampoco me acuerdo muy bien cuando fue.. por esa misma época del 1983/1984, un loco costeño se inventó un canal de la costa, que fue el primer canal regional, entonces ese canal lo legalizaron y fue el primer canal regional que se llama Telecaribe. Por esa misma época se creó Teleantioquia, la ministra de Comunicación en eso entonces era Noemi Sanin y que le tocó la toma del Palacio de Justicia, ella dio la orden de que no se siguiera dando la noticia por radio en ese momento y eso ha sido muy cuestionado si han debido seguir dejando o no. Luego entonces se creó Teleantioquia, que fue el segundo. Por esa misma época se creó Telepacífico, después uno que se llama Canal 13 (no tenía ese nombre antes), que buscaba cubrir de Bogotá hasta los llanos orientales. Ese tuvo su propio desarrollo.

Todos estos canales debían ser sostenidos por las regiones, después se creó el canal de Santander - el Tro (que creo que es el último), y después se creó el canal de San Andrés y Providencia. El Tro es del oriente (límite con Venezuela) que ha sido foco de corrupción. Y después se creó otro que es Telecafé.

Lo interesante de eso es que empiezan a surgir como hongos los canales regionales, pero sin mucha claridad política. Son públicos, canales de servicio público, independientes, es decir, son autónomos pero terminan dependiendo - inicialmente deberían ser financiados por las 
regiones pero terminan siendo parte de la Red Nacional de Canales Públicos y los financia en su mayoría la Autoridad Nacional de TV, que es lo que se creó (antes fue la Comisión Nacional de TV), que es la que maneja los dineros públicos para la televisión.

\section{¿Como se define los porcentajes de dinero que va para cada uno?}

No porque otra forma de financiación es comercial, entonces es un sistema mixto en donde dependen mucho de publicidad y dependen de lo que les de la región. La ANTV les da dinero para mejorar las condiciones técnicas, para gastos de infraestructura, y para programación de un fondo (FONTV), esa Comisión Nacional de TV fue un foco de corrupción espantosa, eso se creó en el gobierno de Ernesto Samper, en los años 1994-1998 (e fica pensando qdo foi...),

\section{¿El año más corrupto fue el de Samper?}

No. Él creó la Comisión. Y cuando leí esa ley me pareció lo máximo, que era una idea brillante, pues era una manera de financiar y regular todo el concepto de televisión pública, la Señal Colombia que era la Señal Nacional y los canales regionales. Lo que no me di cuenta era que el cáliz envenenado estaba en la manera cómo se elegían los miembros de la comisión. Habían miembros que eran los representantes del Congreso, los representantes de las organizaciones de televidentes que no existían, estaban las asociaciones de facultades de comunicación teóricamente, los representantes de gobernadores, un representante del presidente, además era una tragedia porque además del hecho de que fueran 6 siempre hizo que tuvieran que corromperse (eran las facultades de comunicación y educación, los representantes de los canales regionales no de los gobernadores, esos cargos los habían creado el gobernador del estado local, los representantes de las organizaciones de televidente.. ese no era muy sólido. Era para ser lo más independiente y se volvió el más corrupto). En todo caso esto fue la tragedia más espantosa porque los salarios eran superiores a los salarios de un ministro. La Radio Televisora Nacional era financiada en parte por Telecom (empresa de telecomunicaciones) dueña de las redes. RTVC se crea después en 2004.

Habíamos quedado en que existía un canal 3, que se fue convirtiendo en señal Colombia, la peor de todas se quedó en Señal Colombia, no me acuerdo que año pero hace poco, pero lo más importante es que privatizan los canales entonces estaban el Canal 1, el canal de Teletigre y el tercero era la Red Educativa, en algún momento deciden privatizar y entregarle el derecho de un canal a $\mathrm{RCN}$, que es un conglomerado de medios, que era una de las programadoras, detrás del cual está uno de los más grandes empresarios del país que es Ardila 
Lule que tiene las gaseosas y les dan uno de los canales, el otro se lo dan a Caracol (que era radio y TV) que pertenece a los Santo Domingo (ellos tenían las cervezas) que son los grupos más ricos y poderosos del país. Ellos son los dueños de los dos canales privados, el espectro sigue siendo del Estado y ellos pagan una suma muy grande por ese derecho.

\section{En Brasil no pagan nadie, esa lucha que se quiere para que se financie la TV pública.}

Ellos pagan precios altos, hay peleado y han tratado que les bajen los costos que tienen que pagar y han conseguido, su argumento de que cuando tuvieran su propio canal iban a hacer una mejor programación porque antes lo único que ello recibían eran 8 horas en la semana la licitación, entonces ellos decían que si tuvieran más espacios harían televisión educativa, mentira! no han hecho nada de eso, lo único que hacen es telenovelas que no las están haciendo porque la gente se aburrió del dominio de la TV y entonces ya la tecnología permite meterte por Netflix e Internet.

Entonces antes de los canales privados era así: Inravisión, Señal Colombia, infraestructura Audiovisuales, Ministerio de Cultura, canales regionales (Tele islas), Canal Capital que es de la alcaldía que se crea cuando Antanas Mockus (pero no lo puede poner a funcionar porque no tiene modelo) (estaba de alcalde de Bogotá en el 1996) y la programación inicia con (Enrique) Peñalosa. (Antanas) Mockus se inventa una cosa entre los productores (joint venture) y el canal que nunca funciona y nosotros con Adelaida y dos socios presentamos a Mockus 11 propuestas para programas que como no se hizo ese esquema, cuando llegó el gobierno de Peñalosa nos llamaron y nos dieron la franja infantil, se llamaba Franja Metro. Peñalosa fue del 1998 al 2000.

\section{¿Cuando comienzan a trabajar con televisión aquí, ustedes hacían tele con los documentales?}

Sí, pero no los hacíamos para Colombia, lo hacíamos más para el exterior, pero esto fue el primer programa de televisión que hicimos, eran dos horas diarias de TV, allí comenzamos con TV infantil.

\section{¿Esas 11 propuestas fueron la base para la programación de TV en Colombia?}

No, porque la televisión hubiera sido pública con una buena programación si no se privatiza desde el comienzo por un problema político que era TV pública igual a televisión del gobierno, y TV del gobierno peligrosa porque a raíz de esta dictadura militar el país quedó muy preocupado por la libertad de expresión porque cuando estaba este presidente, él cerró estos dos periódicos que eran El Tiempo y El Espectador, la libertad de expresión en este país 
es una cosa que tú no puedes tocar y en aras de la libertad de expresión defiendes cualquier cosa, por ejemplo, el negocio privado de la televisión, por ejemplo, en este país no hay ninguna posibilidad de que tú tranques un programa porque te parece un horror, ni siquiera en la radio, una radio que pertenece a Caracol ó a $R C N$, que hacen unos programas aterradores para niños donde se les ocurren cualquier clase de obscenidad. Tú no sabes la reacción porque una asociación de padres que se llama Red PaPaz, trató de trancar y pedir que cambiaran los contenidos, como si estuvieran mandando los programas más importantes para la cultura occidental, ningún medio se deja tocar un pelo.

Creo que esas cosas pasan en toda parte yo creo, salvo Europa donde hay una independencia, por ejemplo la BBC, es totalmente independiente, se financia con una licencia, con la gente que paga. Aquí la idea que pague alguien está fuera de toda posibilidad pero sobretodo ese concepto de la televisión pública independiente del poder gubernamental es muy complicado, por ejemplo en este momento, Canal Capital, este alcalde lo convirtió en su megáfono para gobernar. Puso a un tipo que es el único de los concejales de la ciudad que fue elegido del gobierno de (Gustavo) Petro (ex-prefeito de Bogotá), él que se va, era el director de Canal Capital, él es periodista contestatario, aunque en el canal hay cosa buenas y plurales, se convirtió en una cosa totalmente de la izquierda militante y a través de ahí gobernaron, pero al mismo tiempo tenían una franja de opinión que era más independiente, pasaron los conciertos del teatro Julio Mario Santo Domingo. Entonces fue una mescla que aparentemente la TV pública y estaba haciendo muy bien su labor con una cosa totalmente politiquera, este es el caso más evidente. No te sabría decir pero creo que Teleantioquia es muy regionalista, cuenta con un programa icónico que se llama Serenata, que saca grupo de cuerdas, pero yo no creo que Teleantioquia haya sido una tribuna de politiquería.

\section{¿Hay otros canales que son politiqueros}

Seguramente deben serlo pero no tan descarado como este de acá. Porque por otra parte también ellos dependen de publicidad y tienen que tener cosas comerciales, pero la verdad es el que el más evidente fue del Canal Capital, que se volvió una cosa terrible, y el argumento era que ellos le daban un espacio a los temas que normalmente no se trataban en las televisiones comerciales (la tele privada), lo cual es un poco cierto.

Indudablemente la cosa comercial es terrible, por ejemplo tenemos en los dos canales unos realities de niños cantando (Voz Kids y Factor FX - que es la familia cantando), los ponen a la misma hora los dos programas, se convierte en una cosa absurda, y muchísimas telenovelas, tienen ahora telenovelas importadas, unas 10 telenovelas por día, la televisión 
privada es una (...) Claro si tú te pones a mirar la parrilla de Canal Capital por lo menos hay temas interesantes y posiblemente vistos, por decirte, cuando la televisión comercial hizo Pablo Escobar y todas estas cosas, estos hicieron un muy buen programa que se llamaba "Las víctimas de Pablo Escobar" era desde un punto de vista histórico y li importante era mostrar que Pablo Escobar era un (peligroso) y quienes habían sido víctimas de Pablo Escobar, pero también hicieron cosa que no habían hecho nunca por costoso, una especia de telenovela que era sobre la historia del M19, el alcalde había sido guerrillero del M19 entonces era una cosa de una cursilería que era realmente patética en que contaban toda la historia del M19 y el robo de (la espada de Bolívar), todas las cosas que ellos habían hecho. Había una cosa tendenciosa hacia la izquierda, no que los planteamientos de la izquierda sean malos, sino que no puedes ponerlos a tu servicio, que si eres del M19....

\section{Comenta sobre o caso do Brasil ... o uso político das TVs públicas}

Eso fue Canal Capital, yo en otros canales no lo he visto nunca, los canales regionales tienen cosas malas, regulares y buenas pero yo no creo que haya habido ningún caso en el que el gobernador haya usado el canal para su servicio.

\section{¿Y como esta la señal Colombia hoy?}

Bien, yo creo que es muy interesante y tuvimos influencia nosotros en el sentido...,

¿como te parece, porque ustedes crearon la idea de lo que seria una buena televisión de calidad

- sobretodo para niños, trabajamos en la necesidad de producir televisión infantil, pero lo cierto es que ese fondo de financiación ha servido para hacer buenos programas. Señal Colombia tiene cosas buenas, yo te diría que desde que empezó... en el primer gobierno de Uribe trabajamos mucho con su esposa peleando contra la Comisión Nacional de Televisión, que era una mierda, pero digamos que ese fondo ha servido para producir programas interesantes, yo diría que la Señal está relativamente bien, que tiene cosas buenas, pero no tiene audiencia, en parte porque no le hacen ninguna divulgación. Sí tienen plata para hacer divulgación porque pueden hacer Free Press... pero yo creo que como reciben plata de la (ANTV).. la verdad es que nosotros hace mucho que no nos metemos con la Señal Colombia. Antes hicimos licitaciones y nos ganamos programa pero yo no podría ser juez de Señal Colombia, a veces tiene cosas muy interesantes. Hay una cosa que a mí me parece interesante, es que cada día hay menos enlatados de telenovelas. Aquí hubo una cosa muy interesante, no sé si también pasó en Brasil, en Colombia hubo una ley que obligó a las programadoras a usar el $40 \%$ o $50 \%$ del talento nacional y al usar ese talento tenían que hacer programas con 
talento nacional, al comienzo patalearon y después se dieron cuenta que era una mina de oro porque desarrollaron todo el mercado de telenovelas y se volvió una cosa muy importante.

Hoy en día está muy mal la producción acá. Los actores están tratando de hacer valer que haga más televisión acá porque parece que los números son aterradores, hasta en los barrios tienen TV a cable. Ya uno no está obligado a mirar la TV abierta. En el 2012 empezamos a trabajar el compromiso con la TV de calidad intentando incidir en las políticas de TV infantil, trabajamos muchísimo, hicimos este compromiso por la TV de calidad. Si te soy honesta lo más importante que hicimos fue crear la conciencia de que debía haber una TV infantil y una producción de TV infantil en los canales públicos porque a los otros los canales privados no les importa (17:03), no logramos lo que queríamos con eso y sobretodo formar gente, hicimos muchas cosas que se llamaban, eventos de Televisión de Calidad, entonces traíamos a Beth (Carmona), a gente, hacíamos talleres, seminarios, presentábamos el Festial Prix Jeunesse aquí.

\section{¿Tu crees todavía en la televisión publica?}

Yo creo, sí, pero creo que incluso ha mejorado.

¿Tiene autonomía e independencia, por ejemplo Señal Colombia, fora las regionales, tiene indepedencia, te parece? Ajuda a tener un canal institucional?

Ayuda la Señal Institucional? Sí porque tiene una separación. Eso acá era muy grave.

Sí, yo creo que eso ha sido muy bueno y fíjate que todos esos han sido como unos offsprings de la Señal Colombia. El Canal Institucional, el Canal Congreso (ellos también tienen su canal) lo cual le quita obviamente plata al...(e fala ao telefone)

Entonces digamos que los puntos claves fueron, por un lado, la privatización de los canales que de alguna manera financió la Comisión Nacional de Televisión y que a pesar de toda la corrupción eso creó este fondo de financiamiento de la programación y de los canales. Ha permitido hacer cosas. Entonces yo te diría que por un camino bastante sinuoso sí hemos llegado a fortalecer la televisión pública, porque ese fondo permite que se hagan programas que no son comerciales. Hay cosas buenas, menos buenas. Por ejemplo hay un tercer canal privado que es local de Bogotá y se llama City TV que es del periódico El Tiempo. Si tú miras, todos tienen un soporte comercial muy fuerte, de grupos de interés muy fuertes (los privados). Los regionales tienen el potencial de hacer cosas locales, de mostrar cosas más locales, y creo que en esta alcaldía se podría plantear un muy buen canal público porque Peñalosa no va a volverlo un balcón para contar su política, pero sí le interesa mucho la juventud, la cultura, el embarazo adolescente. 
¿Hay esperanzas que las cosas mejoren Canal Capital en Bogotá con Enrique Peñalosa? (Foi o Prefeito eleito, resultado saiu naquele domingo)

Sí claro, de eso estamos seguros.

Una cosa que en Brasil tiene en la TV Brasil no es de facto la televisión nacional porque solo tiene canal abierto en Brasilia, en Rio y Maranhão, que es mantenido por la sociedad Brasilera, entonces ellos intentan hacer redes con los canales regionales, pero cuando el gobierno tiene afinidad con el gobierno federal funciona. Usted que consejo daría para la televisión en Brasil, te parece que debería seguir el modelo de Colombia, para no depender del gobierno?

Muy complicado. Primero porque de alguna manera algunas, todos estos esquemas y estructuras surgen de una manera intrincada y orgánica, puntual. Yo creo que lo grave es que ustedes no cobren por los derecho del espectro, porque aquí es lo único que financia. No sé si lo puedan hacer porque no sé si el Estado es dueño.

La concesión es gubernamental, pero lo usan y no lo pagan. ¿por qué no pagan?

Los canales comerciales luchan en los tribunales contra el pago. También en Brasil el espectro es del Estado. Ahora están intentando con las operadoras de celulares y están todas en la justicia. La Globo, no paga, SBT no paga, la Record no paga que es la Iglesia Universal.

Qué va a pasar con el gobierno en Brasil? Si esto no lo consigue el PT no lo va a conseguir nadie.

Hasta ahora no lo han conseguido, si lo han intentado y está en justicia.. hay una discusión muy complicada. Estamos en crisis económica grave, la popularidad de Dilma ha caído mucho, entonces no consigue aprobar nada en el congreso. El parlamento es corrupto y conservador, el presidente del congreso hoy esta con dinero en Suiza que es propina de corrupción esta en juicio con la justicia (em novembro de 2015).

Yo no sé, creo que hay que defender. Está por un lado la privatización de los canales que ha habido una gran discusión de que si se hace un tercer canal privado porque el Canal Uno y el Canal A se lo dieron a estas dos empresas pero quedaron unos sueltos.

Ahora están vendiendo espacios. Todos son del gobierno nacional. Y ese más. Lo que pasa es que lo dejaron para las programadoras independientes que licitan espacios, mientras que cada uno tiene su canal este tiene que licitar espacios y se han unido varias programadoras pequeñas tratando de competir contra las grandes, han podido relativamente. Hay un 
periodista que se llama Yamid Amad, que tiene un noticiero independiente pero él tiene tendencias políticas. Él es el que tiene más poder y más prestigio en ese otro canal. Lo grave es que la televisión abierta está jodida.

Si. Para Omar Rincón ha sido un fracaso, hay un articulo la semana pasada por la crisis de la televisión a cable porque hay una pelea por las Teles, hay muchos aparatos y formas. ¿Tener noticiero en la televisión publica es una cosa complicada? Mañana me encuentro con Alexandra Falla que fue de la ANTV...

Que te cuente ella en que consistió el cambio de CNTV para ANTV porque yo no sabría decirte... Y hasta que puntos se fueron independizando, que cuente la experiencia de como es ser miembro de una asociación que define todo.

Define todo pero le quitaron mucho poder. La Comisión tenía muchísimo poder. La verdad es que yo no sé en qué se diferencia.

\section{¿ Usted cree que tiene independencia, los miembros son escogidos con autonomía?}

Realmente fue tanto lo que sufrimos con la Comisión que parecen mejores pero yo creo que es en parte porque les quitaron mucho poder, pregúntale tú y nos cuentas en qué se diferenció una cosa de la otra con relación a la Comisión y la ANTV. A ella le fue bastante bien, ella ahora está en Patrimonio Fílmico....

(Adelaida habló con ella por teléfono para que me atendiera para conversar sobre el papel de la ANTV)

Creo que ellos han hecho cosas interesantes con la financiación de espacios pero pregúntale quiénes son los representantes porque ellos quitaron unas cosas, peleamos, sufrimos por la Comisión. Lo que sí logramos fue poner el tema de la televisión infantil, eso no existía, y tú no sabes lo que cuestan que lo entiendan porque los canales privados no les importa. Ahora ya no hay franjas y los niños ven todos los canales.

En Brasil hay normas para los horários (Classificação Indicativa), no se puede colocar en cualquier horario las programaciones, entonces los niños se quedan a mirar los canales a cable, porque no hay control de publicidad en ciertos programas y es muy difícil porque como Brasil es grande los horarios no son los mismos (fuso horario)

Aquí me impresiona muchísimo que todo el mundo tiene cable, ya sea por 10.000 pesos en Santa Marta, es una mierda, pero tiene programación infantil. Toda la gente tiene, los niños tienen canales solo para niños.

Brasil es complicado, en las favelas donde vive la gente pobre ellos hacen un cable clandestino y todo tienen TV a cable. Cuando Beth Carmona entra al Televisón Cultura 
fue tanta calidad la TV infantil y ha repercutido y Globo empezó a hacer programaciones infantiles, pero hoy toda la mañana la programación de Globo tiene programas para adultos.

Aquí nosotros trajimos para Señal Colombia una programación maravillosa de todo el mundo a través de una licitación. Lo que me acordaba es que la veían en contra jornada los niños y los maestros no sabían, era una programación que se llamaba Espacio Maestro pero los niñitos todos veían franja Cuatro Caminos, unos programa divinos, ingleses. En fin, lo que pasa es que llega un punto en el que uno se cansa de jalar la carreta.

Es la misma cosa que acontece con Beth Carmona, ella esta muy preocupada en la formación de productores y hace eso muy bien y mucho comKids, tiene festival que estimula mucho o independiente y también unos talleres y ha hecho mucho, hace en las escuelas para los maestros, pero es una lucha que no tiene financiamiento.

Yo me cansé, la verdad...

Gracias Patricia, es tarde, más de 10 h de la noche. Realmente aprecio mucho su atención y paciencia. Gracias por todo. 
APÊNDICE G - TATIANA DUPLAT - Diretora del Proyecto Señal Memoria de RTVC

Grabada día 23/11/2015

\section{Preséntese, por favor}

Soy Tatiana Duplat, diretora del proyecto Señal Memoria de RTVC que es la Radio Televisión Nacional de Colombia. Nosotros somos un sistema de medios públicos. Eso que tú has descrito de Brasil tiene uno equivalente aquí más pequeño, somos un país más pequeño, entonces nuestro sistema de medios públicos tiene dos canales de televisión, tiene Señal Colombia, el otro se llama Canal Institucional, esta es la gran diferencia con lo que tú me estás contando (Junção Radiobras $/ A C E R P=E B C / T V$ BRASIL). Es un modelo que llama mucho la atención en América Latina, porque aquí se ha diferenciado, se ha separado la televisión educativa y cultural de la TV institucional. Y aunque las dos funcionan en el marco democrático, el quitarle el lenguaje institucional a la TV educativa y cultural, las hacen con más posibilidades, más rica, pueden expresar más cosas, pueden decir...y es vista desde la audiencia con menos prevención. Y todo lo institucional - la voz del estado - va por el canal Institucional, se distribuyen por franjas, por espacios, distintas instituciones y además siempre tienen prioridad nichos de interés de la sociedad como el presidente que va a hablar o cosas así. Y ese canal Institucional no tiene noticieros. Se le quitó la opción de dar noticias, lo que hace es informar desde distintas perspectivas lo que hace el Estado colombiano. Y Señal Colombia, que es lo que tú conoces, que está dedicada desde el 2004 exclusivamente a la TV educativa y cultural.

\section{¿Y que tuvo su origen en la Televisión Nacional, Inravisión?}

Sí. Voy a contarte ahora la historia. En el sistema de medios públicos está la Radio Nacional de Colombia y una emisora joven que se llama Señal Radiónica, que es una derivación de la Radio Nacional especializada en público juvenil, y como quinto elemento de ese sistema de medios públicos tenemos La Señal Memoria que no es un medio, ni una emisora, ni una TV, es un proyecto. Ese proyecto busca recuperar el archivo audiovisual y sonoro, el archivo de la TV y el de la radio y convertirlo en un archivo patrimonial, un archivo para el país para que pueda alimentar las discusiones públicas de lo que hemos sido y de lo que queremos ser. El proyecto Señal Memoria reúne 61 años de historia de la TV colombiana y 75 años de historia de la radio.

La radio se creó en Colombia en el año 1940 y la televisión en el año 1953 y se fueron acumulando los registros, las cintas, los soportes, se fueron acumulando y acumulando hasta 
que llegó a ser inmanejable, muy difícil de sostener, pero ahí estaba, lo tenían, lo guardaron, y en el 2004 cuando se acaba Inravisión (Instituto Nacional de Radio y TV), se liquida administrativamente. Fue una época muy difícil, muchos problemas económicos, una planta muy grande, un sindicato también muy complicado. Esto lleva a que se liquida el Instituto Nacional de Radio y Televisión, que era inmenso, y se crea RTVC, esto que te estoy contando. Del 2004 hacia acá es la RTVC. Y en ese momento, en 2004, cuando se va a crear RTVC, el decreto que la crea dice "el archivo de la Radio Nacional es muy importante!", y se garantiza por decreto que ese archivo tiene que tener una gestión y un cuidado especializado, y desde el 2004 hacia acá, sobretodo desde el 2006 hacia acá, ya hay acumulado una experiencia gestionado la Fonoteca. Entonces nuestro archivo existe antes del proyecto Señal Memoria. El archivo es más viejo que nuestro propio proyecto.

Bueno, voy a volver a contarte, en orden. La radio se crea en 1940 con el gobierno de Eduardo Santos, y la tele pública se crea en 1954 con el gobierno de (General) Rojas Pinilla. Se mezclan, se juntan, en el 1964 y se crea el Instituto Nacional de Radio y TV (Inravisión).

\section{¿ Hay una publicación sobre eso?}

Hay en la internet, el boletín monográfico de la Biblioteca Luis Ángel Arango. El boletín del primer semestre de 2015 está dedicado a la historia de la TV. Todos tienen acceso, está online. Está impresa pero creo que en parte. Lo venderon en mayo pero puedes ir a la Biblioteca y preguntar a ver si te lo venden.

En 1964 se crea el Instituto de Radio y TV (Inravisión) que va a funcionar hasta el 2004. Era un gran instituto con un montón de empleados. No tengo esa historia tan exacta.. y empieza a tener muchos problemas económicos y deciden terminarlo, lo acaban, y a cambio crean RTVC. En este edificio donde estás era donde el Instituto funcionaba, con una planta inmensa de empleados, todo se producía aqui (...) pero eso fue quebrando la Institución. Y la deuda que tenían con los trabajadores, todavía no la terminan de pagar.

Entiendo que el modelo era inviable. Termina el modelo y se crea RTVC como una empresa social y comercial del Estado. Funciona como un instituto mixto. Es una empresa comercial y industrial del Estado, es decir, tiene que generar ingresos, poder vender servicios, cambian el modelo. Y en ese cambio de modelo (yo no soy la más experta en esto pero te estoy contando, así, muy general para que tengas un marco), bueno, en ese modelo, parte de lo que hacen es que Señal Colombia empieza a sacar unas convocatorias para que sus contenidos sean producidos por otras productoras, y se establece el sistema de la coproducción. Por eso tu 
comentario cuando llegaste, pensabas que "todo se hace aquí!". Aquí se hacen los lineamientos, hay un manual de calidad - ya famoso-, y se hacen las convocatorias, se consiguen los recursos y se sacan convocatoria y la programación es hecha por los que ganan esas convocatorias. Ellas van dirigidas, por ejemplo, vamos a sacar una convocatoria para ... (Liana: nosotros llamamos de edital, pitching).. exacto! primero presentan los papeles, se selección grupos, vienen y hacen propuestas y el canal hace coproducción - el canal Señal Colombia. El canal Institucional funciona distinto: le venden los servicios a las instituciones dentro del mismo estado.

Paralelo está la Radio Nacional que no ha dejado nunca de funcionar, ha estado siempre muy estable. Y hace 10 años (en 2005) se crea la otra emisora, Radiónica. Ya con una idea de especializar más al público (jovem) y ultimamente como una manera casi de experimento, han puesto en internet Señal Clásica y han hecho intentos con un canal dedicado al rock, Señal Rock. Todos en la web. Este es el panorama. En tanto años se fueron acumulando archivos pero nunca fue organizado, mantenido tecnicamente. Yo creo que nisiquiera como lo que me estás contando de Brasil. La radio, en el 2004, por suerte el decreto dice "la Fonoteca, hay que gestionarla y dedicarle recursos". La Fonoteca lleva unos 10 años intentando organizar este acervo, y ya está más o menos organizado (solo de radio). La Fonoteca existe antes que el proyecto Señal Memoria. Era una dependencia de la Radio Nacional que buscaba recuperar los archivos, digitalizarlos y ponerlos en un catálogo.

El archivo de TV no tuvo esa suerte pero siempre se guardó, y solo desde hace 2 años (en 2013).

\section{¿ Todo esto está organizado?}

Todo está muy heterogéneo: el más antiguo guardado en cajas y el más reciente...

\section{y tiene todo tipo de medios?}

Sí, todos los soportes, desde la cinta de pulgadas hasta la cinta de 2 pulgadas, de cine, porque aquí, cuando se emitió la primera televisión, no se gravó en video pues no teníamos el VTR, no existía.

\section{¿ era todo en vivo, no?}

Todo en vivo y lo que se registraba, se registraba en cine. Entonces tenemos el registro de la TV de los primeros años en material de cine, fílmico.

Y hacia finales de los 1950, inicio de los 1960, aparece el VTR, el telecine, que permite hacer telecinado y poner eso en video. Entonces tenemos en ese archivo de TV 150 mil soportes, de esos, los 30 mil más recientes están más o menos organizados porque era nuestra videoteca 
con la que funciona el canal normalmente. Eso que ves aquí es la programación del canal, del otro año. Paula (Arenas) es la asesora de contenidos y ella, junto con un equipo de trabajo, piensa nuestra programación (es la jefa de Jaime (Tenório), de programación). Este tipo de canal, como está planteado, tiene todos los contenidos "perdurables", no es TV del instante, es TV que se hace pre-grabada con contenidos que se pueden emitir varias veces después en el tiempo.

Pensando en cómo solucionar el problema de como producir día a día y mantener día a día una programación, lo que se hace es que se hacen esas convocatorias a las casas productoras, coproductoras, y se hacen casi siempre documentales y que se espera que sean de alta calidad para que se puedan emitir año tras año, una misma pieza puede ser emitida 3, 4 años después. Por eso, nuestro archivo reciente, el de los 30 mil, con soportes más recientes, está organizado porque de eso depende el canal, de eso vive el canal. Eso llamamos el "archivo de tráfico". Antes del proyecto Señal Memoria estaban a cargo de la videoteca, técnicos de archivo no muy especializados, son técnicos bibliotecarios, ellos no son profesionales, menos tiempo que profesionales, que buscaban una manera de organizar esto fisicamente y llevar esto a un pequeño catálogo muy rudimentario, muy artesanal.

\section{¿cuantos trabajan en esto?}

Inicialmente eran 3, 4 personas, era una cosa muy artesanal. Hoy, ya te voy a contar.. es un proyecto grande. Pero ese pequeño grupo de gente pues solo puede mantener los últimos registros, unos cuantos miles de soportes, los otros soportes acumulados en cajas y cajas y ha pasado el tiempo y ya fue creciendo y nisiquiera había donde botarlos.

\section{¿Y estaba en una sala con una temperatura...?}

No, nada. En cajas. Yo creo que se ha perdido mucho pero aún así tenemos 150 mil.

\section{¿Y se puede recuperar? Hay como tratar?)}

Los hongos tienen forma de tratamiento químico, sí, hay tecnologías. Entonces aquí viene la historia reciente, en el 2013 , hace poco, se crea el proyecto Señal Memoria

\section{¿Y es cuando vienes para aca?}

Yo acabo de llegar este año, 2015. El proyecto primero se crea como una idea de la gerencia, y pasa 2013 buscando los recursos económicos. Eso es muy costoso, pero consigue los recursos. La Autoridad Nacional de TV y el Ministerio de las TICs (Tecnologías de la Información) dando recursos para el proyecto Señal Memoria. Pero lo primero que se hace en este proyecto es, la urgencia es tener la estructura, el edificio, para poder conservar estos 
soportes porque como tú bien lo dices, si sometemos las cintas al proceso de preservación pero no hay donde guardarlas, se pierde el trabajo.

Entonces lo primero que se hace es formular el proyecto en 2013, y en 2014 se construye la infraestructura para el archivo audiovisual, pues la Fonoteca lo tenía resuelto (el audiovisual que era el resalvo histórico). Y en 2015 entro yo con la idea y la tarea darle a esto un contenido historiográfico, ahora sí empezamos a pensar en el proyecto de La memoria para qué? y pensando mucho en el momento histórico y político que vive Colombia, a punto de firmar un acuerdo de paz, la memoria es muy importante para nosotros porque es un momento en que muchos sectores se empiezan a pensar cómo vamos a vivir a futuro. Y solamente pueden mirar a futuro si conocen la historia

\section{Liana habla del período de la ditadura en Brasil, cadenas, programas infantiles...}

Entonces la memoria en este momento del país es muy importante, y en muchos sitios, tenemos el Centro de Memoria Histórica, el Museo Nacional de la Memoria, muy centrado en las víctimas, y en el conflicto armado. Pero en este contexto, tener al archivo nacional y no darle una orientación política, no era posible, entonces la misión en este momento del proyecto superado un poco la urgencia de la infraestructra es darle un lineamiento político.

Cómo es el proyecto: tenemos dos tareas, una hacia adentro y otra hacia afuera. Hacia dentro, institucionalmente, la tarea es tomar la experiencia de la Fonoteca, que ya tenía una experiencia grande en radio y transferir este conocimiento al archivo de TV y hacer un solo archivo patrimonial. Patrimonial porque la diferencia es que hasta este momento, el archivo, incluso de la Fonoteca, estaba pensado para el interior de la entidad, para RTVC, para responder intereses y necesidades de la sociedad. Ahora lo que queremos construir es hacerlo hacia afuera. La meta es algún día tener todo esto en una plataforma digital para que los ciudadanos puedan entrar, consultar y acceder a esta informacíon, a este archivo. Entonces, una misión es adentro, organizar institucionalmente las dos areas: Fonoteca y videoteca y convertirlos en un archivo, adelantar los procesos de recuperación, que son complejos, hay mucho material, hay que limpiar por fuera, limpiar por dentro, con máquinas (Liana habla como se hacia antes, en Brasil), y cada soporte necesita una máquina diferente, el Betacam necesita una, la de Pulgada necesita otra. Estamos en el proceso de limpiar y digitalizar (era un volumen muy grande y administrativamente muy difícil). Lo que hemos hecho es que buscamos a nuestros vecinos, la Fundación Patrimonio Fílmico. La otra preocupación es que tenemos un tesoro pero no hemos descubierto este tesoro. Sabemos que está ahí pero nosotros no sabemos qué hay dentro. Entonces decimos que estamos quitando tierra al tesoro para 
descubrir qué es lo que temos. Claro, tenemos muchas pistas, evidencias, sabemos, imaginamos lo que puede haber aquí pero no lo sabemos, no está catalogado, ni organizado, nadie lo ha visto. Entonces la idea de mandar esto a digitalizar a cualquier empresa y perder el control se llama la cadena de custodia del patrimonio era muy peligroso. Entonces fue perfecto que la Fundación Patrimonio Fílmico está aquí al lado, somos vecinos, hemos hecho un convenio con ellos y con ellos hemos salido unos expertos que han hecho lineamientos y estamos en este momento echando a andar los procesos técnicos de recuperación de este material. Habíamos tenido la entidad RTVC, antes de que yo viniera, había hecho una primera prueba de 9 mil soportes que mandaron a digitalizar y a catalogar a una empresa por fuera pero aprendimos que no era una buena opción hacerlo por fuera. Hay que hacerlo aquí para poder aprender.

Tatiana invita Liana para visitar la zona y ver parte del proceso (parte lo que hacemos en Patrimonio Fílmico).

\section{(Liana relata que ha lido el artigo de Omar Rincone n El Tiempo que habla de Senal} Memoria?) Sí, él estuvo con nosotros en el foro donde presentamos el boletín bibliográfico. Ese boletín fue hecho con la RTVC y nosotros hicimos el lanzamiento de este boletín en mayo con Omar Rincón, y él escribió ese artículo.

(Liana habla de un texto del inicio de la producción)

Lo primero que dijeron aquí fue "necesitamos aprender" porque eso es un campo muy especializado, y el canal no tiene esa experiencia, entonces empezaron a traer el año pasado con la Fundación Patrimonio Fílmico, iniciaron unas discusiones con unos expertos para empezar a ir por donde y para identificar. El sector es muy grande. Para poner en el equipo de trabajo, yo busqué un experto en procesos técnicos, uno en curadoría y gestión de colecciones para los contenidos y uno en comunicación del archivo, no encontrábamos en ningún lado.

\section{¿ Aqui hay facultad de archivista?}

Hay una maestría en preservación del patrimonio audiovisual y sonoro

Liana dice que Brasil tiene la Facultad biblioteconomía y otra de Archivología y cuenta la forma como era al trabajar con archivos en Brasil en la ACERP- Rio de Janeiro)

Mira que problemas tenemos con eso, en Colombia es de los pocos países del mundo donde la bibliotecología sigue siendo un pregrado. Entonces, en el resto del mundo, la bibliotecología se volvió un postgrado, post, después. Entonces la gente estudia economía y luego hace postgrado en bibliotecología y conoce primero el tema.

¿Cree que es mejor un postgrado? 
En el resto del mundo funciona así. Aquí no. Aquí es un pregrado y está muy pensando en el libro. Está muy centrado en el libro.

Entonces, qué problemas tenemos para catalogar audio? Las chicas que estudian aquí, casi siempre son mujeres, están acostumbradas que el libro te da toda la información porque abres y aquí hay una ficha que te dice cómo catalogas. Aquí tienes que saber. Entonces pones un audio de los años 1950 y te habla de un presidente y a esa chica que estudió 4 años bibliotecología no le dice nada o cualquier tema porque la radio es muy difícil de catalogar. Un día de programación en radio te puede hablar de 10, 15 temas distintos, de música contemporánea, de historia. Es muy difícil catalogar radio entonces trabajan aquí bibliotecnólogas que hemos encontrado que hay que formar y entrenar por temas especializado porque es muy, muy difícil.

\section{Liana dice que tiene que registrarse en la documentación los nombres de los compositores y músicos, as veces Rusos, checos y otros...}

Y como no hay una referencia escrita tampoco saben cómo buscar en internet. Eso ya es una larga experiencia de la Fonoteca que el proceso tenía que hacerse aquí para poder ir entrenando la gente pero eso es muy costoso porque esas son instituciones de todas maneras inestables, la gente va y viene, se pierde mucho. Por el problema administrativo que hubo con Inravisión no quieren tener una planta muy grande.

Dicen que este negocio de las plataformas con las ODTs va a cambiar completamente. Dicen muchas cosas: qué va a pasar con la TV y cuál es el futuro de la radio con internet. Es muy incierto. Y yo siempre digo que lo único que es de verdad y cierto es que el archivo va a quedar. Puede desaparecer RTVC, puede acabar Señal Colombia, Radio Nacional, pero el archivo no, porque ya se produjo, ya está ahí, nadie lo cambia. Entonces vale la pena esforzarse para hacerlo bien. Va a quedar!

(Finaliza la entrevista) Muchas gracias, Tatiana, por su atención 
APÊNDICE H - ALEXANDRA FALLA ZERRATE - Diretora Fundación Patrimonio Filmico de Colombia (ex integrante de CNTV y ANTV)

Grabada día - 23/11/2015

http://www.patrimoniofilmico.org.co/index.php/documentos-y-publicaciones/documentos/198alexandra-falla-zerrate

\section{Alexandra, por favor, háblame sobre tu visión y cuáles crees que son los caminos para la TV pública}

Tuve la oportunidad de trabajar como asesora en la Comisión Nacional de TV, luego como miembro de la junta directiva en la Autoridad Nacional de Televisión y de ser directora operativa de um canal regional de Bogotá, que es uno de los más grandes (Canal Capital), y tuve la oportunidade de trabajar en el Operador Público, que en ese momento no era RTVC sino Inravisión (antes del 2004) y fui Directora de la Radio Nacional, en Inravisión, que es la radio pública.

Basicamente, yo diría que la televisión pública en América Latina en general tiene el mismo reto que es poder superar los temas puramente políticos y gubernamentales para realmente generar una parrilla de programación que responda a las necesidades, expectativas y funciones que debe cumplir la televisión pública en términos de construcción de ciudadania, en términos de fortalecimiento de la identidad, en términos de cohesión social y el gran reto siempre es poder desligar eso de los gobiernos de turno. Y tanto la pública nacional como la pública regional siempre se ven afectadas por las decisiones políticas. Es decir, tú puedes tener um alcalde, como en el caso de Bogotá, que decida darle muchos recursos al canal y puedes tener otro alcalde que decida no darle muchos recursos y priorizar de otra manera.

La Autoridade Nacional de Televisión, hoy, les damos un recurso promedio a los canales regionales entre 7 y 8 mil millones de pesos al año. Pero obviamente, dependiendo de los departamentos de los cuales estemos hablando o de las regiones de las cuales estemos hablando, esa plata que el estado le da como televisión pública tiene más o menor peso, por ejemplo, mientras que para el TRO - canal regional del Oriente - la plata que le da la ANTV es el $80 \%$ de su presupuesto, altísimo, en el caso de Teleantioquia o del Canal Capital, que son grandes, la plata que le da la ANTV es el $40 \%$ de su presupuesto.

\section{¿Cómo es decidido eso? Quién decide ese percentual?}

La ANTV decide cuánto le da a cada regional, pero cada municipalidad, cada departamento decide también cuanto le da a su canal. Entonces, obviamente si el alcalde de Bogotá le da 
mucha plata pues lo que le da la ANTV es poquito. Si le da poquito, eso se vuelve mucho. Si no le da nada, eso es todo. Y así pasa. Por ejemplo, en San Andrés, la plata que le da ANTV es casi que toda la plata del canal. Entonces mientras algunos viven con 7 mil millones al año, otros viven con 25 , otros viven con 30 mil. Entonces es muy desigual la plata con la que cuenta cada canal regional. Y tiene que ver, claro, con la solidez financiera de los departamentos: no todos tienen plata para invertirle de manera tan importante en la televisión. O no todos políticamente ven que es estratégico meterle tanta plata en un canal de televisión. $\mathrm{Y}$ ese es otro tema. Es una decisión puramente política: cuánto le doy yo al canal de la ciudad? Si me interesa, si no me interesa. Entonces obviamente, yo lo que creo es que la regulación y la normativa tendrían que, de alguna manera, tratar de bajar mucho el efecto que tiene las decisiones políticas en los canales regionales. Porque puede suceder eso, que yo vengo de una muy buena parrilla de programación que está teniendo êxito y llega un gobierno nuevo y dice "a mí esta apuesta no me interesa". Y la cambia completamente. Y eso pasa. Entonces estoy pensando en el caso del distrito de Bogotá, del cielo a la tierra va a cambiar lo, tengo claríssimo (con las eleciones de aquel año). Digamos que el anterior gerente, que era un hombre de izquierda, decidió que su apuesta como canal, como eje vertebral de la programación del canal era el tema de derechos humanos y paz. Y me parece que era una propuesta coherente. Independientemente si estoy de acuerdo o no estoy de acuerdo, me parece que era super coherente y atravesaba toda la parrilla de programación. Toda. Era muy coherente. Insisto, puede que a uno no le parezca. O sea, le parezca que el canal no deba ser para eso, pero era super coherente. Pero estoy segura que hoy va a cambiar. No me cabe la menor duda. Porque digamos que el gobierno que llega es un gobierno bien distinto que creo que ve la realidad social de forma distinta. Creo que también hay una apuesta de paz. Pero es lo que estábamos diciendo, tú puedes considerar que esa debe ser una función del canal de Bogotá y otros pueden considerar que no. Entonces, es una decisión personal de quien manda. Y el que está ahí en la cabeza también es una decisión de quien está mandando. No es una meritocracia. Es un nombramiento político y a veces son afortunados y a veces no son afortunados.

Estaba yo un día discutiendo con un senador que uno debería, de alguna manera, en la ley, poner algunos requisitos para ser gerente de un canal: que indiquen una calificación, porque claro, puede ser gente muy buena pero sí tienes que llegar a aprender de televisión, tienes que saber cuál es la diferencia entre una micronda y una FLY, tiene que aprender, por más inteligente que sea, te tardas de seis meses a un año y en eso ya se fue la mitad del gobierno. 
Entonces es muy complicado. Digamos que parte de ese reto sería poder tener unos perfiles para elegirlos, haga un nombramiento político pero hagamos eso.

\section{¿ANTV tiene el poder de fiscalizar lo qué se passa?}

Sí, pero la autoridad se mete solamente en los temas que tienen que ver con la ejecución del presupuesto que da la autoridad. Meterse en el resto es muy difícil. Y te voy a decir que yo fui representante en esa autoridad de alguna manera en los canales regionales y siempre discutía mucho con mis colegas porque yo les decía "nosotros no nos podemos meter a decirle al canal que es lo qué tiene que hacer y cómo lo tiene que hacer, es decir, yo no puedo decir "usted tiene que hacer el $50 \%$ en el formato documental y el otro $50 \%$ así.. no.

Yo no puedo vulnerar la autonomía que tiene cada canal. Obvio. Como con los hijos. Pues eso siempre tiene riesgos. Hay unos que aprovechan bien esa libertad y otros que no. Entonces, eso no es facil. Pero siempre, o por lo menos es mi opinión, yo siempre prefiero que haya excesos porque hay libertad y no que no haya porque hay censura. Y de alguna manera si yo le digo "lo que usted tiene que hacer es esto y esto".. le estoy coartando su libertad.

Qué tratábamos de hacer en la Autoridad cuando yo estuve allá? No nos vamos a meter a decirle exactamente a usted qué es lo que tiene que hacer pero sí le vamos a dar unas líneas, por lo menos. Con la plata que yo le doy yo les voy a dar unas líneas de acción y usted las desarrolla como le parezca. Entonces le voy a decir, por ejemplo, que debe haber un tanto por ciento en programación infantil. Por qué? Porque la televisión privada se olvidó de ese público.

Entonces sólo tienen televisión infantil los niños que tienen cable. Pero la televisión privada se olvidó por completo. Entonces fíjate que eso ha sido bueno. Por qué? Porqué la televisión pública se ha vuelto fuerte en programación infantil. Pero un poco porque haya visto que hay un vacío que está dejando la televisión privada. Y ese vacío hay que aprovecharlo en términos de audiencia. Y eso yo lo pensaba mucho cuando estaba en Canal Capital, yo era programadora y yo decía que uno no se puede poner a competir con un canal privado, por ejemplo, haciendo un reality. No, para qué? Que lo hagan los privados. Además si gastan 500 millones de pesos en cada capítulo, cómo la televisión pública va a competir con eso? Definitivamente, y esa siempre fue mi idea, hay que contraprogramar lo que programa lo privado porque uno no se puede poner a competir con la infraestructura económica que ellos tienen para hacer o una novela o un dramatizado. Mira, aquí hubo un intento hace muy poco en hacer un dramatizado interesante sobre un período de violencia importante en la historia del país de la década del 80 y es terrible porque en los dramatizados va mucha plata y un 
dramatizado sin plata al aire se nota. Ni los buenos actores que dicen "listo, voy a hacerlo por poco dinero" se nota, o sea, se ven malos. Entonces uno no se puede poner a competir con lo que realmente no puede. Los dramatizados, realities, las noticias requieren mucha plata. Sin embargo ahora los regionales tienen casi todos noticieros. Señal no, cosa con la que yo nunca he estado de acuerdo. Por ejemplo, siempre nos ha dado miedo que haya un medio oficial tipo BBC, tipo RAI o tipo TVE española, yo les digo "pero por qué nos da miedo hacer noticias?" Es que es la versión del estado y está bien que haya una versión del estado, lo que es muy importante es que haya cinco visiones más. Pero que la del estado se lea y que yo entienda que es el estado el que me está hablando. Para mí no está mal, es una versión oficial. Pero siempre lo importante es tener la oficial más cinco más, lo terrible es que aquí yo sólo tenga la del estado. Pero aquí siempre nos ha dado un poquito de susto y Señal Colombia creo que alguna vez hizo un intento de hacer unas píldoras informativas de 3 minutos cada hora pero nunca noticieros.

\section{Liana comenta que hablo sobre eso con Jaime Tenorio...}

Creo que es como un susto, yo le decía yo a Jairo, al gerente de RTVC, uno podría nombrar como tiene la BBC, que tiene como un consejo editorial, una gente muy importante que no va a dejar que se vuelva "de bolsillo" - que no se vuelva descaradamente pro gobiernista: "de bolsillo - yo haga lo que se me da la gana". No. Un nivel que permita que sea gente con un criterio periodístico importante que tienda obviamente a la objetividad de la información, aunque ella no exista. Una vez les decía a mis alumnos cuando me decían "la objetivad existe o no existe?", "Yo creo que no existe, pero no quiere decir que uno no propenga por tenerla". Son dos cosas distintas. Puede que nunca la logremos pero yo tengo que ir caminando hacia tratar de ser objetivo. Lo que pasa es que nunca se puede ser objetivo al $100 \%$ porque siempre cualquier visión de la realidad va a estar cercada por quien la está viendo y cómo la está viendo y en que alguno de la información está parada. Al 100 no existe pero hay que propender por tenerla.

\section{¿Usted todavía ministra clase?}

Sí pero poco. En la universidad pero no en cursos tan extensos sino cursos cortos como talleres. Yo siempre dicté Teorías de la Comunicación y luego Legislación y derecho a la comunicación.

\section{¿Cuál es tu formación?}

Soy comunicadora social, luego hice una maestría en Ciencias Políticas y luego una especialización en Propiedades Intelectuales y Derechos de Autor. 


\section{¿Cuántos miembros tiene la Comisión Nacional (Autoridad Nacional)?}

El número de miembros no ha cambiado. Cambió realmente fue el origen de la entidad, que me parece que no fue un buen avance porque la Comisión Nacional de Televisión era un organismo de carácter constitucional y en ese sentido tenía mucho más autonomía y ahora es del gobierno. (Atende o telefone)

\section{¿Tú habías dicho que la CNTV es constitucional, y la ANTV?}

Es legal

\section{¿Cuál es la diferencia entre Legal y Constitucional?}

La diferencia es que tú no podías desaparecer de un brochado a la CNTV porque para hacer una reforma constitucional se requieren dos pasos en el Congreso. En cambio, para hacer una reforma legal si yo quisiera desaparecer la CNTV hago una reforma en la ley y se fue, chao.

\section{¿En el reglamento, cuando están creando la RTVC todavía existe? En qué año estuviste en la CNTV?}

A mí me tocó la formación de la CNTV del 1996 al 1999 casi al 2000, pasé por todas las discusiones, y luego estuve en la Autoridad del 2012 al 2015, también estuve en Inravisión y en un canal regional, o sea, tengo la mirada desde todas las orillas.

\section{¿Y porqué saliste de ANTV?}

Porque es un periodo fijo

\section{¿Y en la CNTV?}

4 años

\section{¿Fue antes del 2012?}

del 1995 al 1999

\section{¿Entre las dos estuviste en Canal Capital?}

Sí. Estuve en el Canal Capital del 2003 al 2006 más o menos

\section{Yo estuve en un canal en 2003, eso en Brasil...}

Y en Inravisión estuve del 2000 al 2003. Cuando yo estuve en Inravisión me tocó la liquidación de Inravisión, yo salí y los 3 o 4 meses liquidaron Inravisión. Para mi gusto no quedó bien armado esto de RTVC. No he entendido eso de contratar y contratar gente. No es subdirección técnica. No hay una cabeza que sea de un ingeniero que se encargue de los temas por ejemplo. Lo que es un poco loco.

\section{Cuándo era Inravisión era mejor?}


Tenía un problema muy grande del sindicato. Un sindicato de trabajadores muy fuerte. Hizo mucho daño a la entidad. Porque yo creo que como entidad no era mala, pero el problema es que la gente tenía demasiados sueldos al año entonces las cargas prestacionales eran una $\cos a .$.

\section{Dicen que va mucha plata para las pensiones.}

Obvio! 50 mil millones de pesos al año. Se comen las pensiones en Inravisión. Entonces la gente se pensionaba a los 50. Entonces eso le hizo mucho daño a la entidad.

No se hace producción interna. Todo es con convocatoria, no, ¿en Señal Colombia por ejemplo?

Sí, hacen algunas internas. Los juegos nacionales los hacen ellos. Pero han encontrado en el esquema de las coproducciones una salida interesante. Lo que pasa es que el tema del derecho no es tan facil. Porque cuando tú coproduces las cabezas de cada quien tienen particularidades.

¿Y cuando quieres hacer una distribución a otros, hay que tener autorización, es muy complicado, no?

Derechos de autor hoy es bien complicado.

Tú conoces más pq has escrito libros. Para usar una foto es una complicación, no?

Ahora estamos apoyando a RTVC como una Fundación de Patrimonio Fílmico en un proceso de digitalización y verás los problemas de derechos.

Trabajé con arquivos, acervo, en la rádio MEC en Rio de Janeiro, los documentos muy viejos/ eram complicados, primeiro pela conservación, digitalización, higienización. De TV es mas complicado porque tienem las cintas pero no los equipos que las transmiten.

Creo que aquí sucede lo mismo, ¿no?

\section{¿Cuánto son los miembros de la Junta?}

Siete

¿Y en ANTV cuántos son?

Cinco.

¿Y esos cinco son de representaciones de qué?

1) es el presidente, 2) el ministro de las Tecnologías de la Información, que también es gobierno, 3) un representante de los gobernadores, 4) un representante de la sociedad civil y 5) un representante de las universidades.

¿Y de la sociedad quien los nombreas? 
Gobernadores, sociedad civil y universidad se hacen vía concurso por una universidad. Una universidad contrata, yo me presenté con 20 personas más, cada gobernador postula el que quiere y concursamos y uno se tiene que ganar el concurso

\section{¿Eso los representantes de la universidad?}

Los tres: gubernadores, universidad y sociedad civil son por concurso

\section{Eso me parece bueno.}

Eso es bueno, sí. Lo que pasa es que también ha llegado a un exceso de academia, no?

\section{Y la academia está durmiendo... en otro mundo,}

No conocen la realidad del mercado de la televisión y uno regula sobre el mercado de la televisión y no sobre el deber ser de la televisión como medio..

Estamos muy mal en América Latina.. la EBC también pasa por problemas (en 2015).. ¿qué caminos ves para eso?

Finalmente en Colombia la TV pública ha venido fortaleciéndose y ha venido ganando espacios, por ejemplo la gente no se imagina su región sin su canal regional, quieren su canal regional sobretodo ven sus noticias del canal regional, porque el nacional no los cubre realmente, y no dice lo que está pasando en la esquina, allá, en el pueblo, en la ciudad de... Entonces digamos que tiene un nicho importante, yo creo que ha venido fortaleciéndose y tiene con la ANTV una oportunidad de fortalecimiento de no morir, no? Siempre es una

\section{Es triste pero es la realidad.}

Porque obviamente implicará en ya no programar un canal sino programar tres canales.

\section{Ah entendido una cosa de Señal Colombia, pregunté a Jaime cuántos son los funcionarios y me dijo que 2 . Y yo cómo??}

Todos son contratistas.

\section{Contratistas son ...?}

Porque para RTVC la idea era dejarlo en lo mínimo pero eso pues termina siendo contratados pues no alcanza con 2 personas, 3 personas,

\section{¿contratistas son contratados por temporario?}

Sí. Pero a veces esos contratistas se repiten, se repiten, se repiten.. entonces te da la misma que tenerlos contratados.

\section{Pero no es mejor que repitan? Por que contratar toda la vida?..}

Pero eso es un problema jurídico. Si no lo sabes hacer, es un problema jurídico. Porque una persona que tu contratas, y contratas, y contratas, y contratas te demanda y dice "oye, yo he 
tenido un contrato laboral, me tienes que pagar lo que no me has pagado: prestaciones, vacaciones", eso es complicado.

Porque en Brasil hacen concurso público para EBC. Los contratistas (de indicaciones del gobierno) reciben mas plata porque tienen cargo diretivos. La EBC tiene 2.273 funcionarios - demitiram muchos de ACERP.. Y han hecho concurso publico y la mayoria es joven. Salen de la universid, no saben lo que hacen, es una estabilidad para siempre...

\section{¿Que caminos ves para que la TV sea siempre innovadora, creativa?}

A mí malas que malas las producciones de Señal Colombia me parecen interesantes porque ha entrado a participar de la TV pública una gente joven, creativa que de alguna manera ha refrescado la TV pública. Así que a mi ese caminho me ha gustado. Tiene ese tema de los derechos y demás que hay que ver cómo se ajustan contratualmente. Pero me parece que esas convocatorias de coproducciones primero le han dado nivel y calidad a las producciones y segundo la han refrescado bastante. Porque la gente tendía a ver la televisión pública como algo muy aburrido, muy denso y han hecho cosas muy interesantes en la TV infantil por ejemplo, y ahora han atendido a un nicho de población que en Colombia está desatendido, que es súper importante, porque hacen cosas muy buenas para niños y nadie más está haciendo cosas buenas para niños sino los canales regionales y la TV pública. Yo creo que la tele pública tiene en la digitalización una oportunidad. Si Señal Colombia pudiera, por ejemplo, tener un canal de TDT solo para niños, eso sería buenisímo porque no hay un canal para niños en Colombia, colombiano, o un canal regional por ejemplo. Lo que pasa es que la producción para niños es costosa. No es barata.

Yo sé por qué trabajo en el Midiativa, con Beth Carmona, que organiza el comKids, (Festival comKids Prix Jeunesse Iberoamericano) los programas de Señal siempre conquistan los primeros premios, junto con PakaPaka de Argentina.

Ahora, qué hay que lograr? Qué falta? Lo que yo creo que le falta a esa programación de Señal Colombia es Promoción y Mercadeo, porque son muy buenos produtos (...) la audiencia es muy bajita. Pero yo creo que es un tema de promoción y de mercadeo. Es decir, hay cosas, y lo discutíamos mucho con los gerentes de los canales regionales, hay cosas en las que uno debería tener la mentalidad de los privados. Y esta, de la promoción y mercadeo, es una. Ellos sí saben promocionarse y mercadear. Cosas bastante malas, que la gente termina viendo. Ahora, si tú promocionas un producto tan bueno como estos, ...

¿Y si hicieran campañas outdor, los canales privados harían presión? 
Obviamente que los canales empezarían a preocuparse, pero es que fíjate por ejemplo que están atendiendo un nicho de mercado que ellos no. Que es algo inteligente. Sí, porque no le hacen competencia realmente. A quien le hacen competencia es al cable, que son los que tienen canales infantiles. Pero los privados no. Tienen una franja de 10 a 12 de la mañana el sábado , "chao", no hay más para niños, la tele infantil en los canales privados desapareció, no hay nada. Por eso! Entonces, digamos que no es tan grave en la medida que no les estás haciendo competencia al nicho de ellos, estás cubriendo un faltante que ellos no tienen. Entonces, en la medida en que hay competencia, hay presión, pero si no hay competencia, la presión es menor.

En Brasil, cuando Beth estaba en TV Cultura (SP), Fundação Padre Anchieta.. hicieran Castelo Ra Tim Bum.. se dedicaran mucho a los niños. TV Globo por la mañana hoy no tiene nada para niños.

Aquí tampoco, nada. Solo Señal Colombia y los canales regionales.

\section{Gracias por su atención}

(Termina entrevista. Alexandra tiene una reunion) 